\title{
The National Petroleum Reserve in Alaska
}

\section{Earth-Science Considerations}

By George Gryc

\section{U.S. Geological Survey Professional Paper 1240-C}

A story of the building of a geologic data base, the interaction of industry and Government, and the role of the U.S. Geological Survey 
United States Department of the Interior

DONALD PAUL HODEL, Secretary

\author{
Geological Survey \\ Dallas L. Peck, Director
}

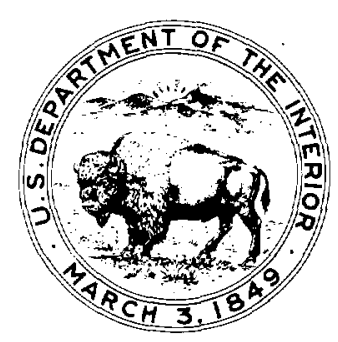

\title{
Acknowledgments
}

This book is the product of many contributors who have provided text, graphic material, and ideas. They are, in alphabetic order, Kenneth J. Bird, Mary M. Brosgé, Catherine C. Campbell, Sarah B. Griscom, George Gryc, Paul Y. W. Ho, Charles E. Kirschner, Robert J. Lantz, Leslie B. Magoon III, Linda OlsonGonzales, and Norman Scott III. To these and the many other members of the U.S. Geological Survey who supported, reviewed, and provided technical assistance, I express my appreciation.

Library of Congress Catalog-Card No. 85-600533

COVER: Landsat photograph of the National Petroleum Reserve in Alaska area. GEOPIC image mosaic (c) Earth Satellite Corp., Chevy Chase, Md.; used with permission. 


\section{The National Petroleum Reserve in Alaska}

\section{Earth-Science Considerations}

By George Gryc

\section{U.S. Geological Survey Professional Paper 1240-C}

A story of the building of a geologic data base, the interaction of industry and Government, and the role of the U.S. Geological Survey 



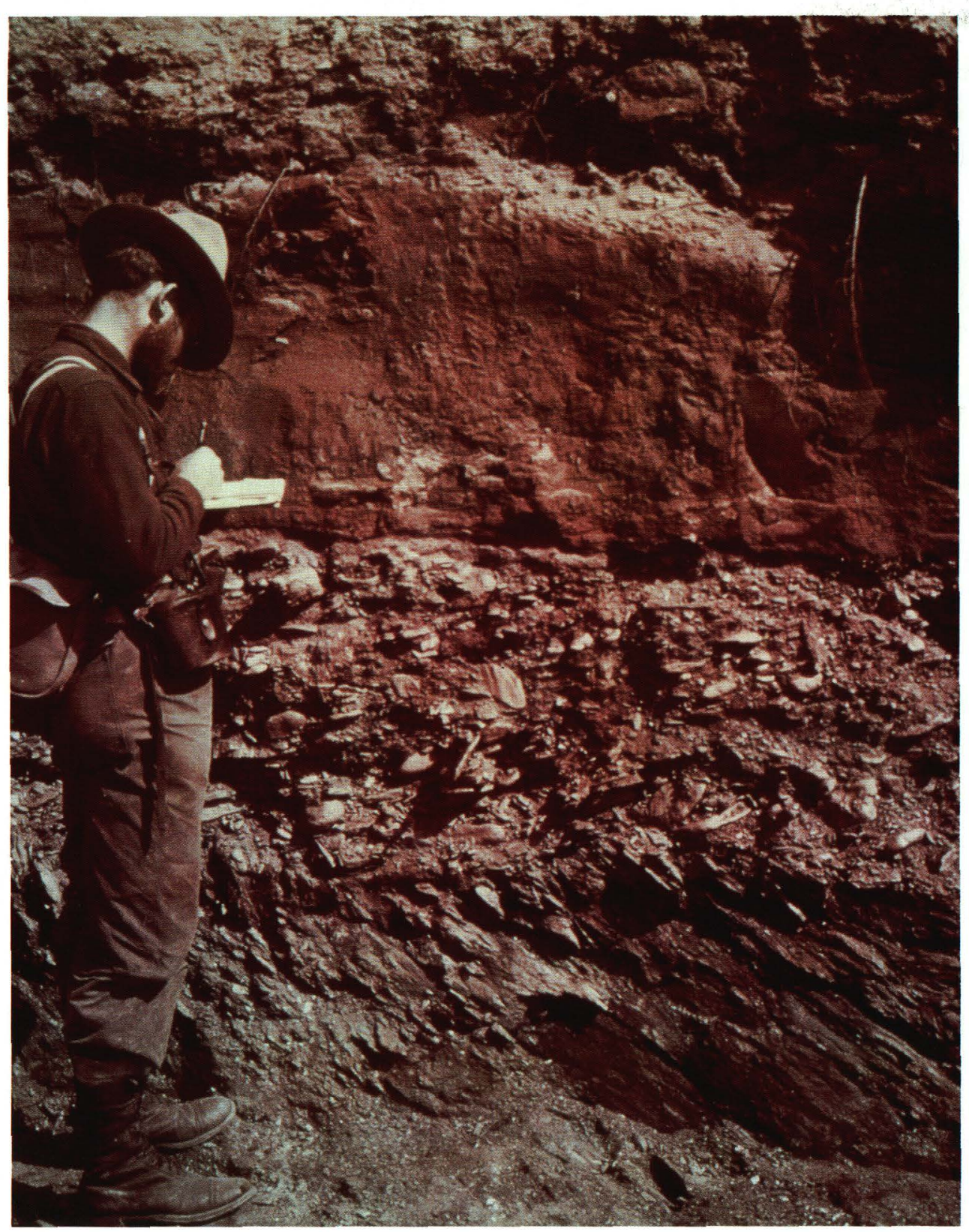

\section{Foreword}

The long history of petroleum exploration in Arctic Alaska by Government and industry began in earnest in 1923 with the establishment of Naval Petroleum Reserve No. 4 and climaxed in 1968 with the discovery of the largest oil field in North America at Prudhoe Bay. Geologists and topographers of the U.S. Geological Survey played a vital role in this exploration.

The administrative programs of and actions by the Federal Government in the development of this region have been driven by the Nation's needs for energy fuels, predictions of coming shortages, and actual short-term crises, such as the Arab oil embargo of 1974. The Nation's concerns for the environment and the well-being of the Native population in this remote Arctic wilderness have added to the complexities of such policy decisions.

This book provides a graphic overview of the gradual accumulation of information on the geology and geography of northern Alaska, exemplifying the leadtime required for resource exploitation and the difficult environmental considerations involved. It should serve to illustrate how interagency cooperation and a good working relationship between Government and industry have functioned during a crucial period of resource expansion and ecologic awareness, in successfully dealing with the challenges that still face us for an uncertain energy future.

Dallas L. Peck

Director

Alfred H. Brooks writing in his field notebook. In 1903, the Division of Alaskan Mineral Resources was established within the USGS. Brooks was its first Geologist in Charge and continued in this capacity until his death in 1924. He was instrumental in planning some of the first geologic explorations, and the topographic-mapping program of the newly established Naval Petroleum Reserve No. 4 and the Brooks Range were named in his honor.

The Colville River, frozen solid 8 to 9 months out of the year

meanders across the Arctic Coastal Plain from the Brooks Range.

Photograph by Jeep Johnson. 


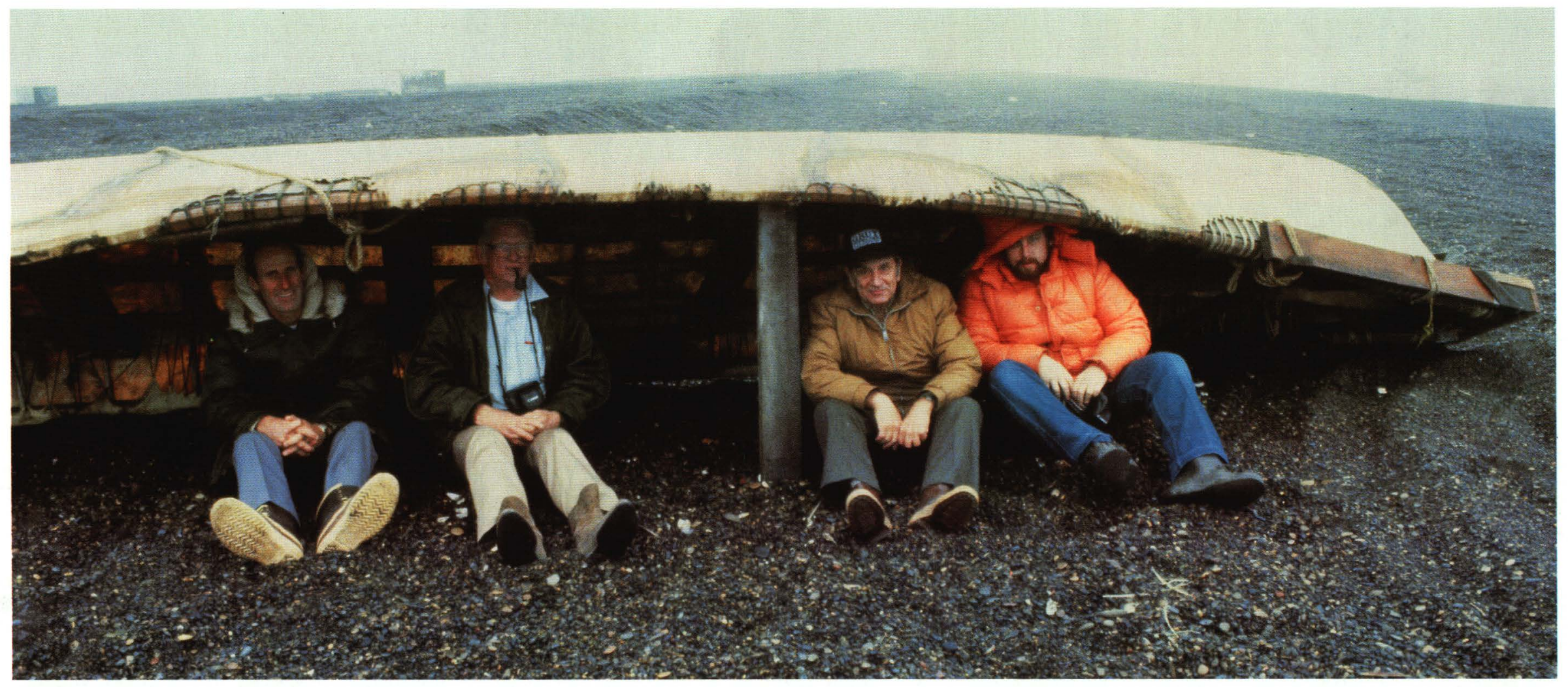

Scientists visiting Barrow seek refuge from the foul weather beneath a handmade umiak. Photograph courtesy of George Gryc.

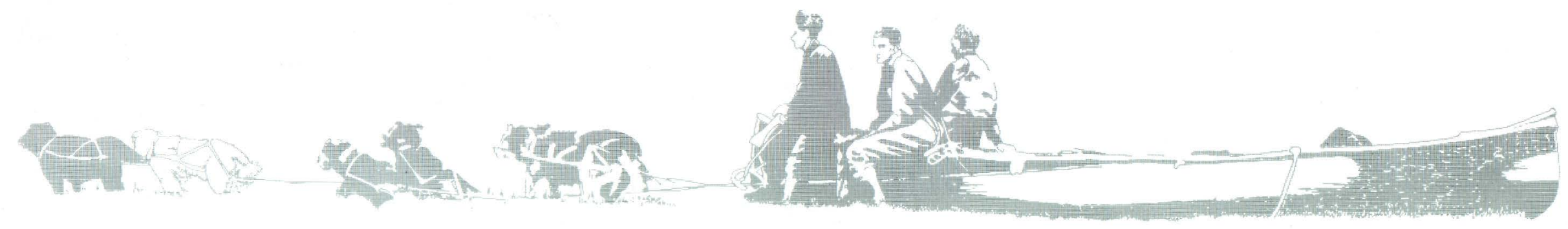




\section{The National Petroleum Reserve in Alaska}

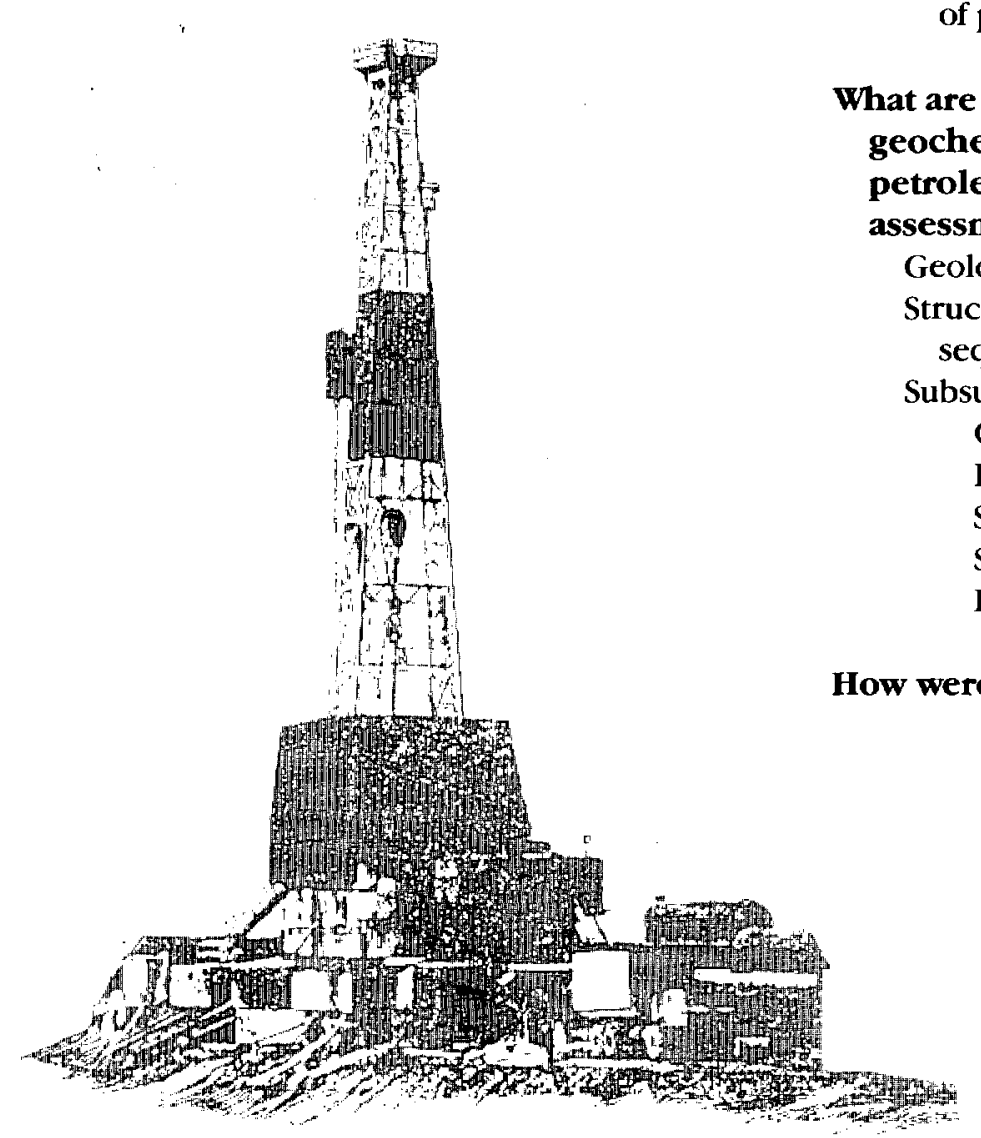

Introduction $\mathrm{Cl}$

What and where is the NPRA-and how was it established? $\mathrm{C} 4$

NPRA established C4

Geographic setting C6

Who and what live on the North Slope?

C8

When, by whom, and how was the NPRA explored? $\mathrm{C} 10$

Early exploration $\mathrm{C} 10$

Geologic and topographic surveys, 1923-26 C10

The Pet-4 exploration program, 1943-53 C14

The 1974-82 exploration of NPR-4/NPRA C15

Summary of significant events in the history

of petroleum exploration in Alaska $\quad \mathrm{C} 17$

hat are the geological, geophysical, and ochemical factors considered in etroleum exploration and resource : 19

C20

tructural elements and stratigraphic sequences C22

Subsurface geology C24

Geophysical surveys C24

Exploratory wells C28

Subsurface stratigraphy C32

Source rocks C34

Reservoir rocks C36

ow were oil and gas resources estimated?
What were some of the geotechnical,

engineering, and environmental

considerations in the exploration and

development of the NPRA? C44

Surficial materials C44

Permafrost C48

Environmental stipulations and monitoring

Trafficability and movement of supplies and materials C56

$\begin{array}{lc}\text { Logistics } & \text { C57 } \\ \text { Airstrips } & \text { C59 } \\ \text { Ice roads } & \text { C62 }\end{array}$

Ice roads $\mathrm{C} 62$

Drillsite construction C65

One-season drill pads $\mathrm{C} 65$

Year-round drill pads

C71

How were cleanup and rehabilitation accomplished? $\mathrm{C} 72$

What is the story of the Barrow gas fields?

The role of the USGS at Barrow

C79

Gas consumption C80

Gas production $\quad$ C81

Prospects for supplying future demands C85

The USGS' accomplishments at Barrow

What is happening with the leasing of NPRA lands? C89

What is the leasing program?

C89

Summary of the USGS' accomplishments in the NPR-4/NPRA program C90

Exploration program and hydrocarbon assessment $\mathrm{C} 90$

Cleanup, rehabilitation, and environmental considerations C9l

Operation and maintenance of the Barrow gas fields $\mathrm{C} 92$

Termination of the NPRA program

C92

References cited C93 


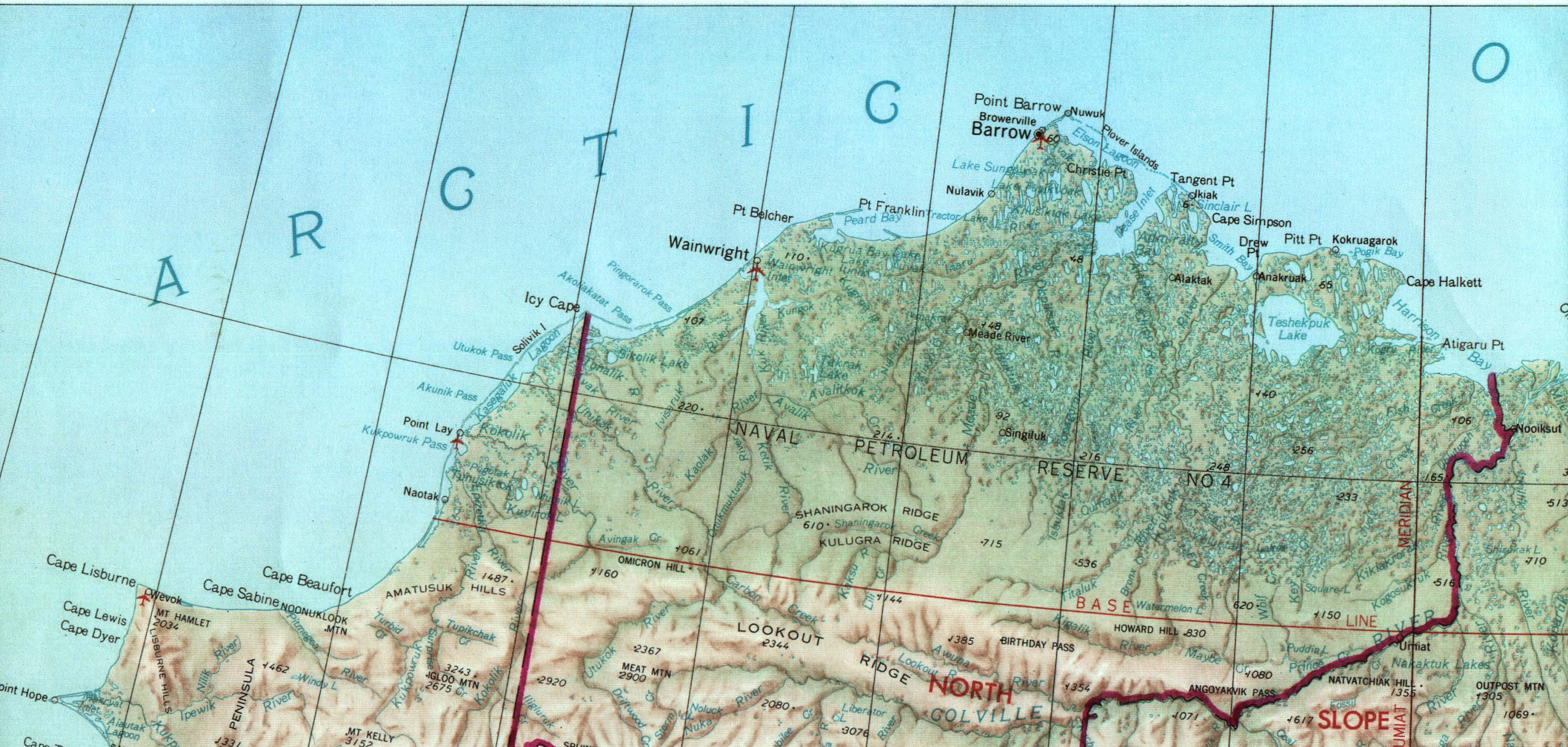

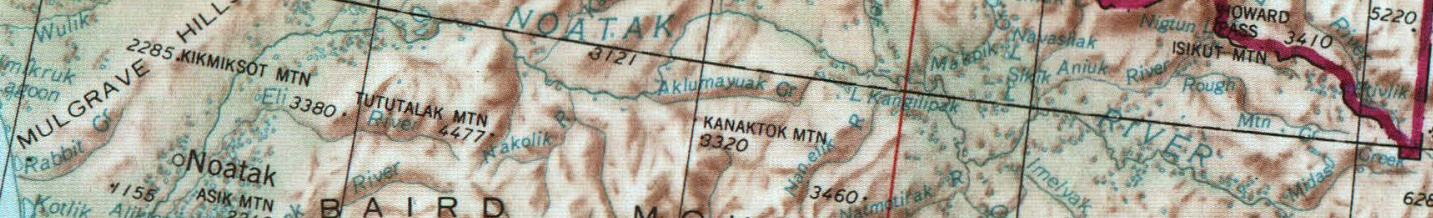









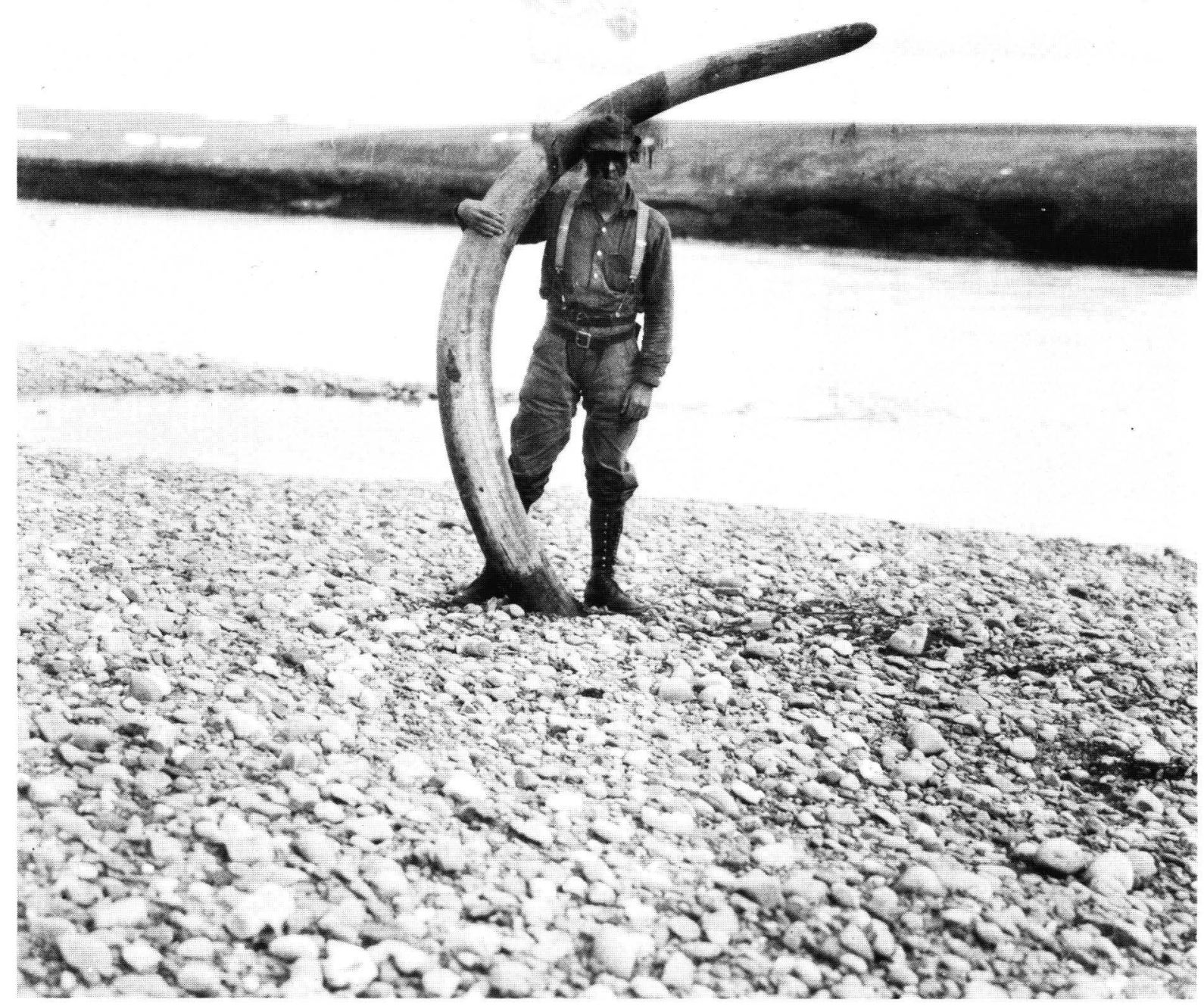

Recognizing the need for more complete information on the new Reserve, the U.S. Navy requested the USGS to map the area covered by NPR- 4 and the assess the petroleum resources. The fieldwork was done from 1923 to 1926 , and the results were published in 1930. From 1944 through 1953, the U.S. Navy undertook the first modern oil-exploration program in the Arctic. The USGS again worked with the Navy and, beginning in 1958, compiled and published all the available technical data in Professional Papers 301 through 305. Several noncommercial hydrocarbon accumulations were discovered by the Navy, and the feasibility of using modern petroleum exploration and production methods in the Arctic was established and documented.

In 1976, NPR-4 was renamed the National Petroleum Reserve in Alaska (NPRA), and the USGS was assigned the lead responsibility for further exploration. Additional gas accumulations were discovered in the NPRA but were of insufficient size to be developed for export. However, the knowledge of the geology of Arctic Alaska and its potential resources was expanded significantly.

The early USGS expeditionary surveys (1901-26), as well as the more recent exploration activities (1944-82), in the NPRA have been in keeping with the Survey's charter to survey and map the topography, hydrology, and geology of the Nation and to assess its water and mineral resources. To fulfill these responsibilities, the USGS is continually increasing its capabilities not only by collecting additional data but also by research in the basic principles of the earth sciences. Ongoing studies include the source of hydrocarbons (oil, gas, and coal); hydrocarbon maturation, migration, and accumulation over geologic time; and the structural and stratigraphic geologic factors that lead to accumulations of these vital commodities.

"Sandy" Smith holds a mammoth tusk found in gravel beds of the Colville River, 1924. Photograph courtesy of Phillip S. Smith.

C2 THE NATIONAL PETROLEUM RESERVE IN ALASKA 
The basic knowledge gained from these studies has been, and continues to be, made available to the public through written reports and maps. Building on this information base, oil companies have explored and discovered the largest hydrocarbon accumulation in North America at Prudhoe Bay on the Arctic coast, just east of the NPRA. In addition, new interpretations of the geology of the Arctic and its relation to that of the rest of the world have added to our understanding of Earth processes. The resource discovery and development at Prudhoe Bay have quickened exploration throughout the Arctic and focused worldwide attention on this frontier region.

The fascinating story of the NPRA and the role of the USGS from 1901 to 1984 is outlined in the pages that follow. This story serves as a case history of (1) the building of a geologic data base that preceded discovery, (2) a good working relationship between Government and industry, and (3) interagency cooperation.

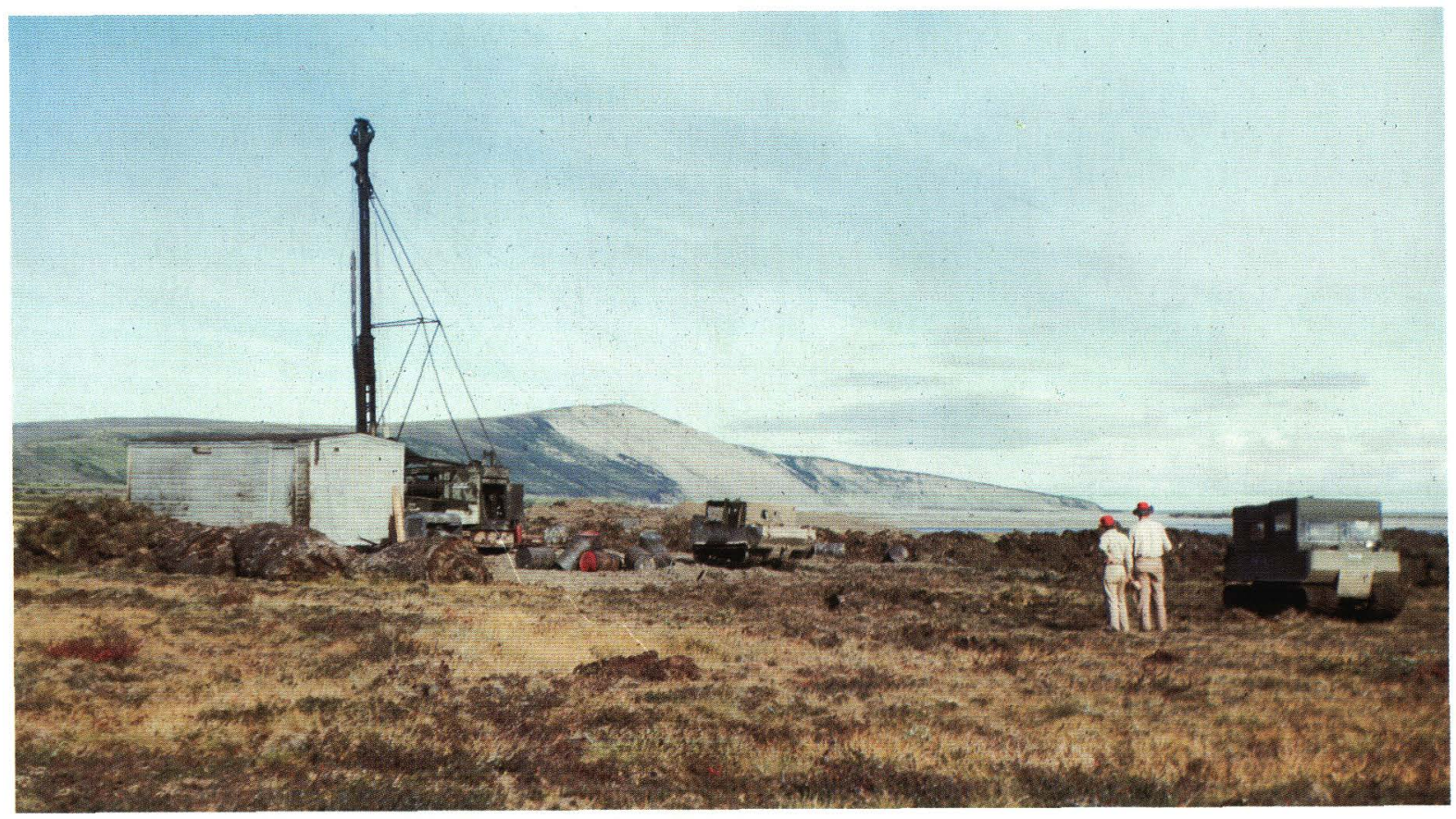

Some of the first exploratory wells in NPR-4 were drilled at the Umiat oil field, about 1945. Photograph by George Gryc.

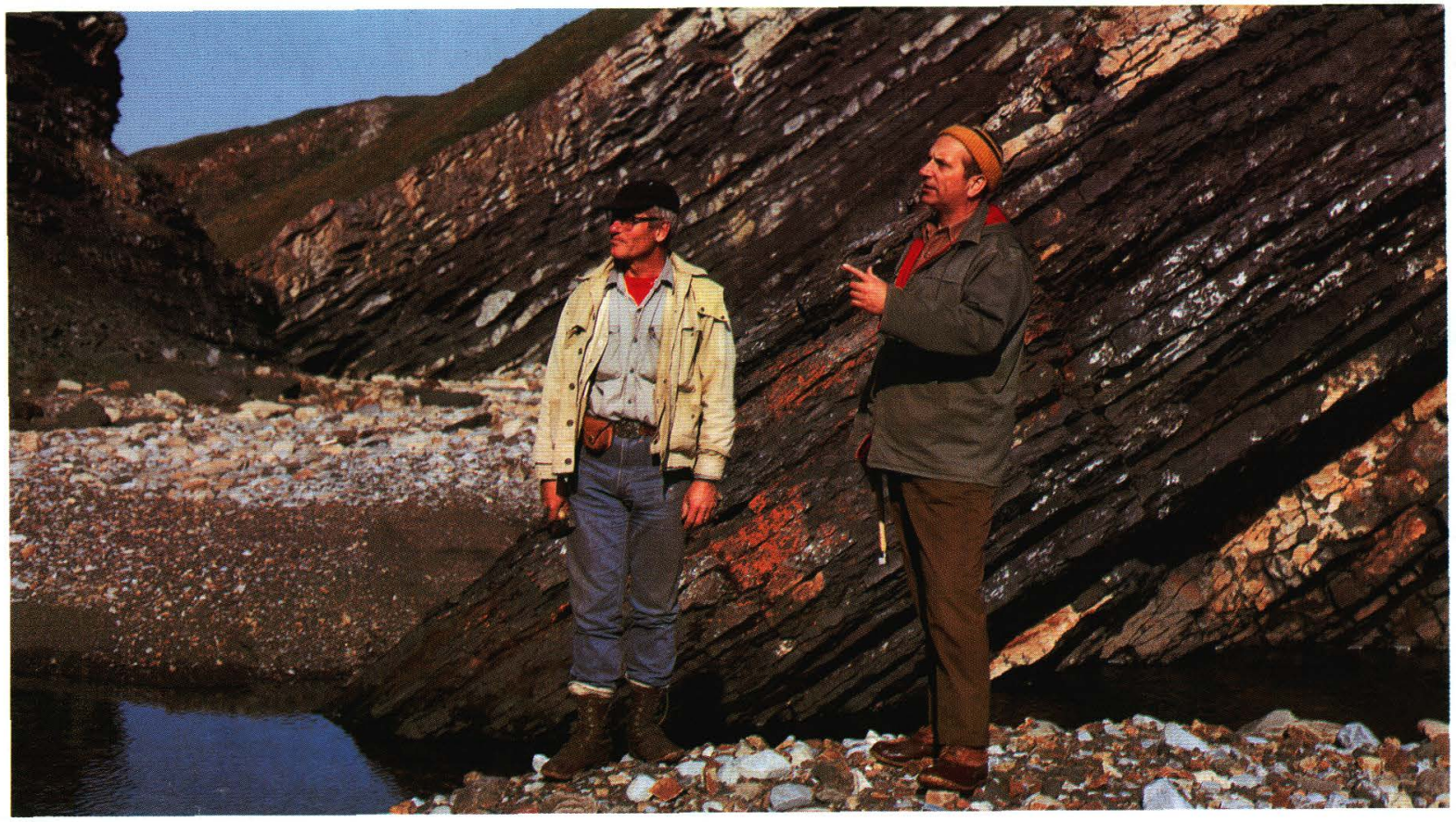

Robert Detterman and George Gryc discuss Alaskan petroleum resources. Tilted oil-rich shale beds are visible in the background. Photograph courtesy of George Gryc. 


\section{What and where is the NPRA-and how was it established?}

Oil seeps, such as this one near Simpson, provided clear evidence to early explorers that petroleum-rich rocks were present beneath the Arctic tundra. Photograph by George Gryc.

\section{NPRA established}

In 1923, President Warren G. Harding set aside, by Executive Order, a Naval Petroleum Reserve, later designated No. 4, in Arctic Alaska. His Executive Order reads, in part:

"Whereas there are large seepages of petroleum along the Arctic Coast of Alaska and conditions favorable to the occurrence of valuable petroleum fields on the Arctic Coast and,

WHEREAS the present laws designed to promote development seem imperfectly applicable in the region because of its distance, difficulties, and large expense of development and,

WHEREAS the future supply of oil for the Navy is at all times a matter of national concern,

Now, THEREFORE, I, WARREN G. HARDING President of the United States of America, by virtue of the power in me vested by the laws of the United States, do hereby set apart as a Naval Petroleum Reserve all of the public lands within the following described area not now covered by valid entry, lease or application: ${ }^{* * *}$,

\section{WARREN G. HARDING}

The White House,

Feb. 27, 1923.

$$
\text { No. 3797-A. }
$$

The first description of oil seepages at Cape Simpson by A. H. Brooks was published in 1909 in USGS Bulletin 379. Eskimos had known of these seepages, as well as of oil shales that burned like wood; they had used both for fuel long before recorded history. Although these leads were in a remote and isolated region of the then Territory of Alaska, oil prospectors were already following up on them. Crude oil had been discovered and produced in the conterminous United States, but experts, including some prominent geologists, were predicting that resources were limited and soon could be in short supply. Oil was rapidly replacing other sources of energy (coal and whale oil), and oil for ships was considered critical to the Nation's welfare and defense. Thus, the establishment of a Naval Petroleum Reserve in Arctic Alaska was fitting.

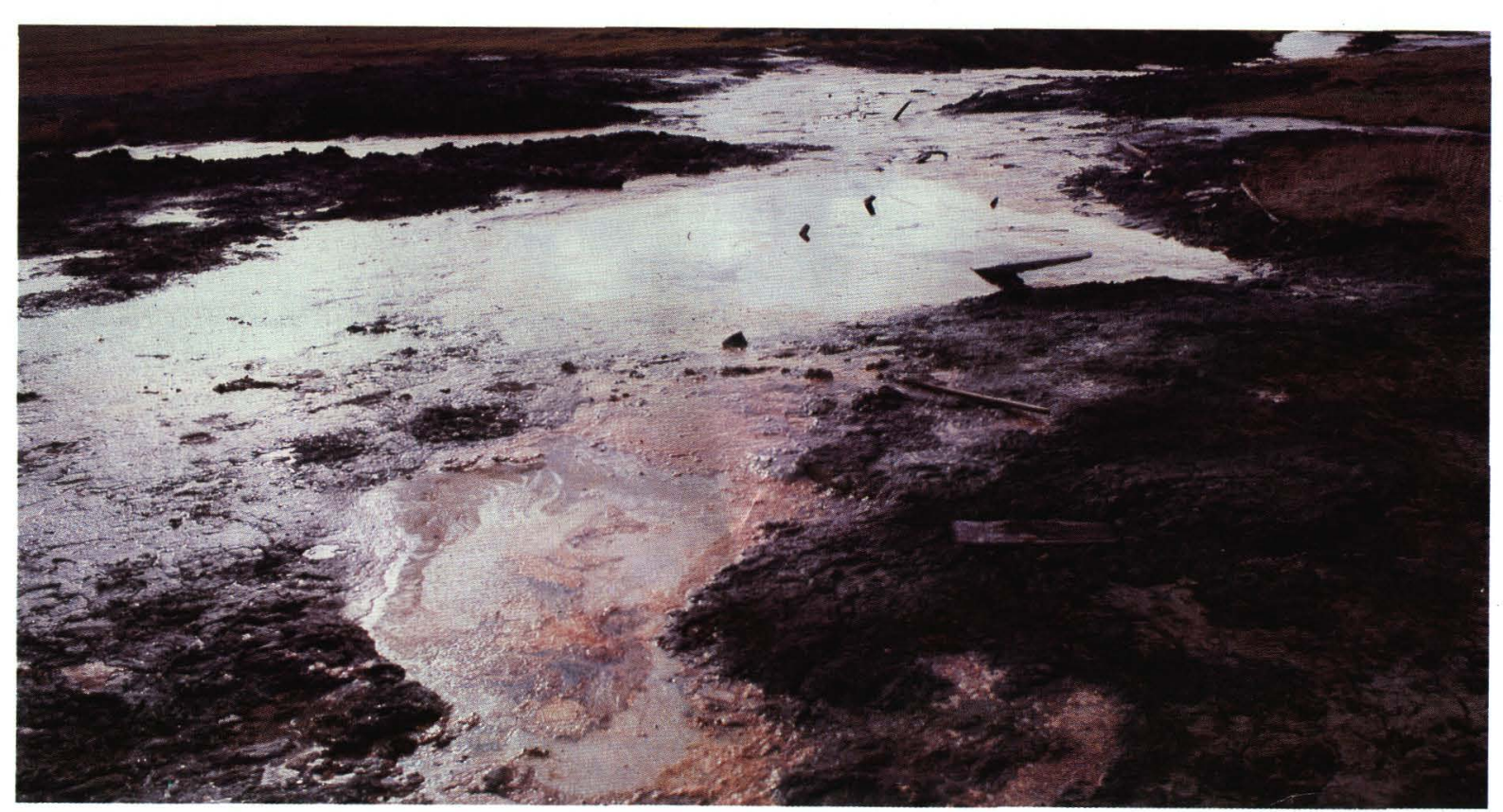




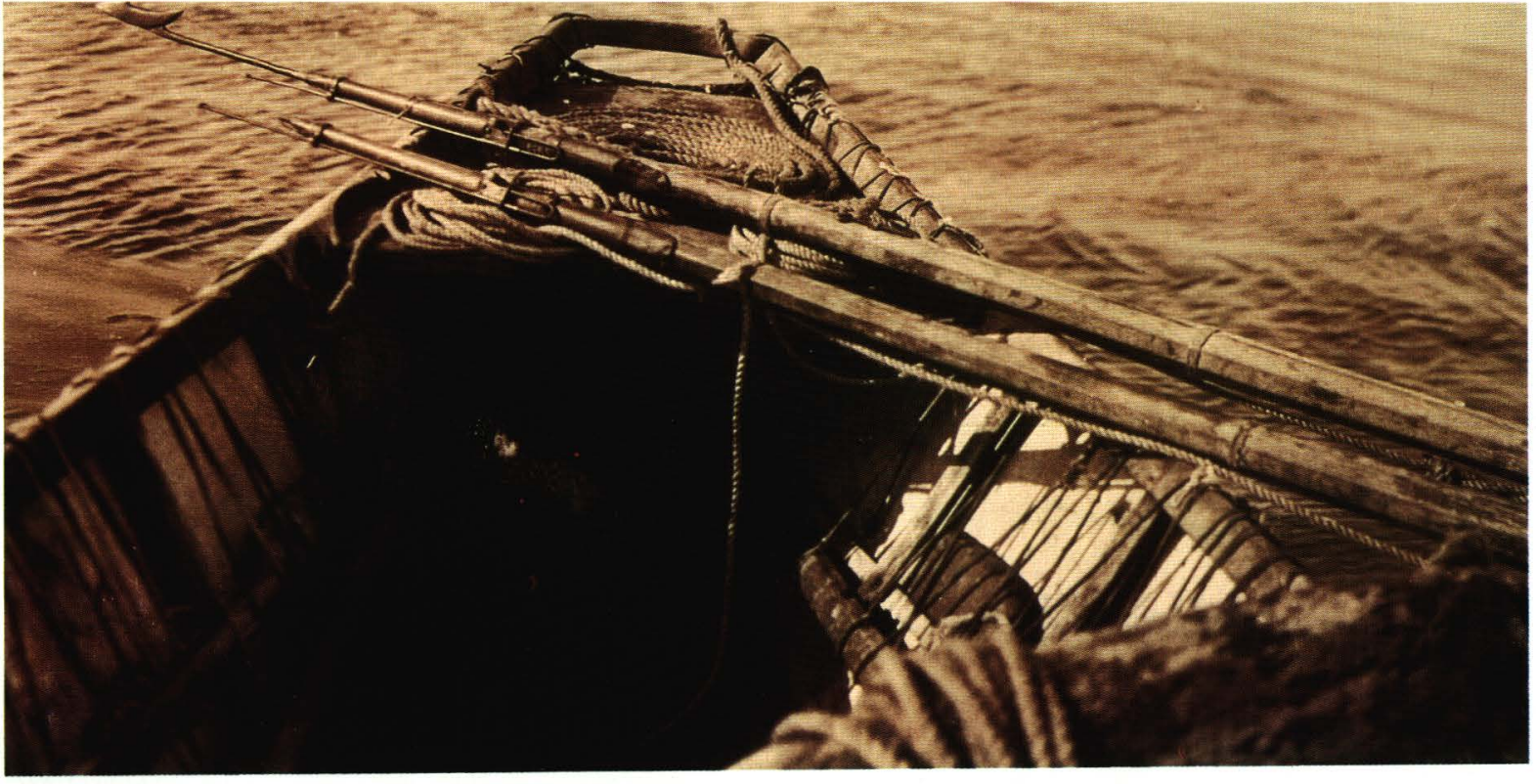

Eskimo canoe outfitted with a whale-darting gun, ready for the hunt, about 1924. Photograph by Charles Brower.

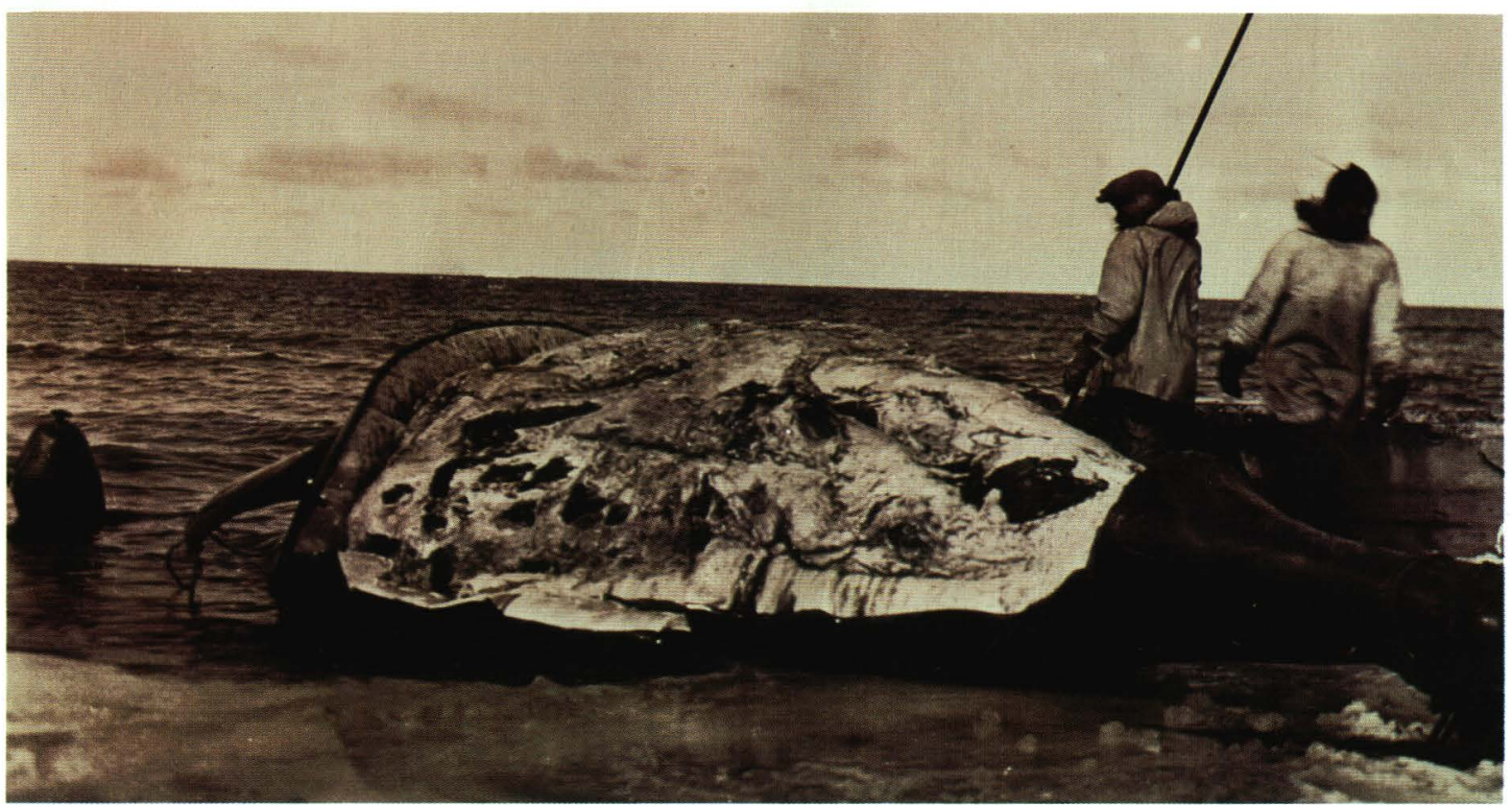

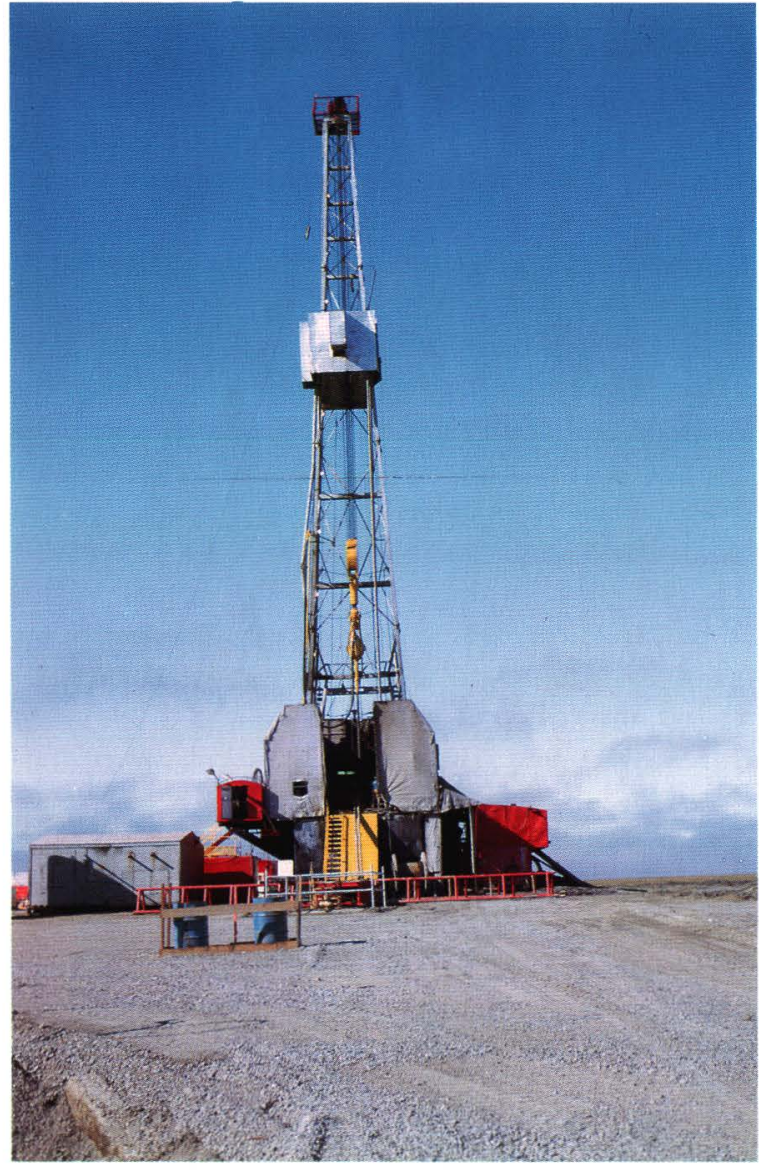

Drill rig at Prudhoe Bay. Many wells produce more than 5,000 barrels of oil per day. Photograph by Robert Lantz.

Eskimos (about 1924) used whale oil as well as oil shale for fuel long before recorded history. Photograph by Charles Brower. 


\section{Geographic setting}

The entire NPRA is north of the Arctic Circle. It occupies an area about the size of the State of Indiana-some 37,000 square miles. Its north boundary is the Arctic Ocean, and about half of its south boundary follows the watershed divide of the western Brooks Range, thence northward to the Colville River, and along that river to the Arctic coast.

Northern Alaska and the NPRA are divided into three major physiographic provinces: the Arctic Coastal Plain, the foothills, and the east-west-trending Brooks Range that cuts off this Arctic region from the rest of Alaska. The Brooks Range forms a major watershed, the north slope of which drains into the Arctic Ocean-thus the terms "Arctic Slope" and "North Slope" of Alaska. The mountains form an arc, concave northward, of complexly folded and faulted rocks. Peaks range in elevation from 3,000-4,000 feet in the west to more than 9,000 feet in the east. The foothills immediately to the north consist of low synclinal mountains separated by broad anticlinal lowlands that give way to long, continuous, east-west-trending ridges covered by a green tundra mat. These ridges gradually blend into the vast, nearly treeless coastal plain dotted with literally thousands of shallow northwest-oriented lakes.

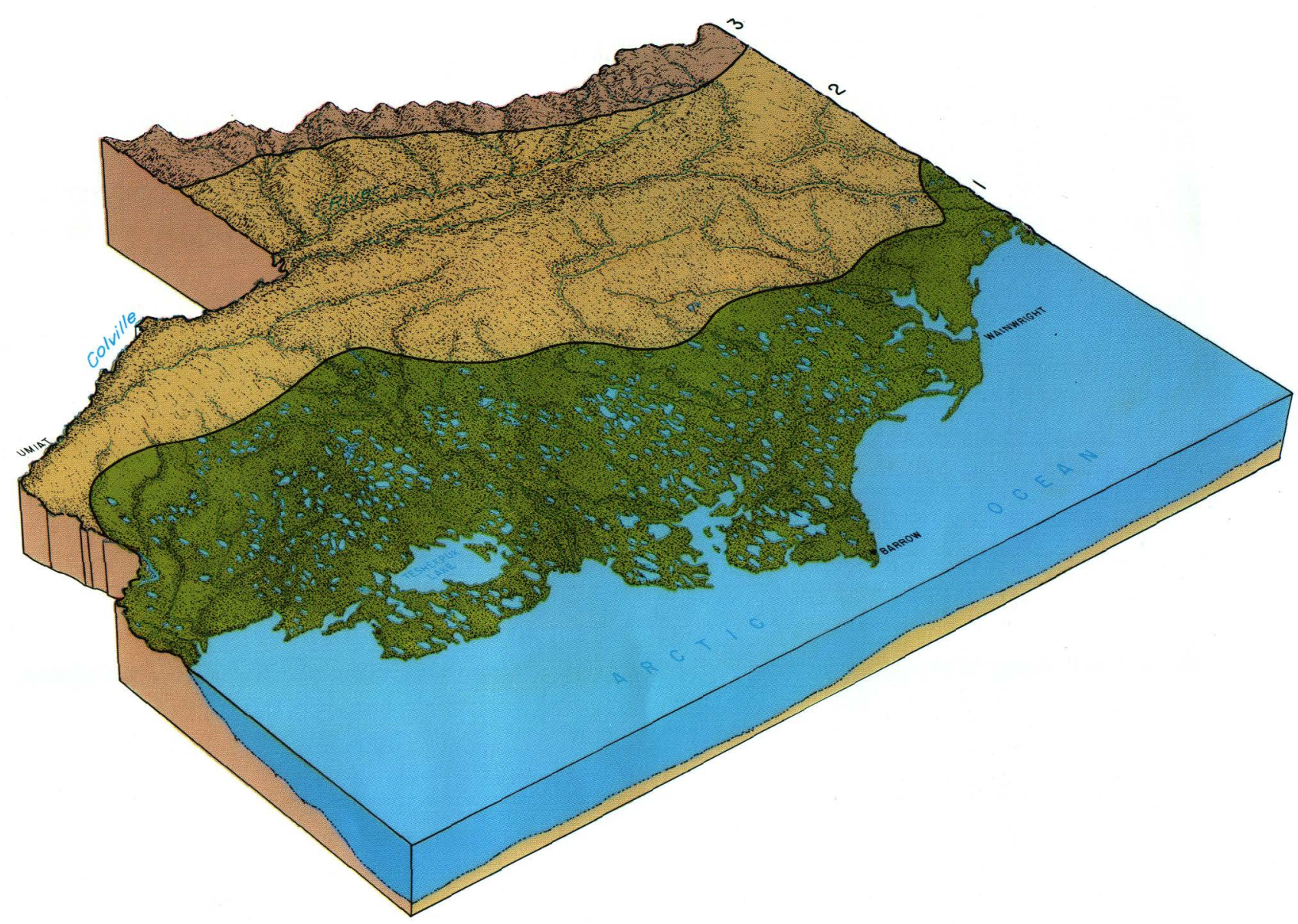

From north to south, the NPRA consusts of (1) the Arctic Coastal Plain, a broad, flat expanse dotted with lakes; (2) the foothills, an area of rolling hills; and (3) the Brooks Range, a rugged mountain range with elevations as high as 5,020 feet within the NPRA and peaks of 8,000 to 9,000 feet near the United States-Canadian border. 


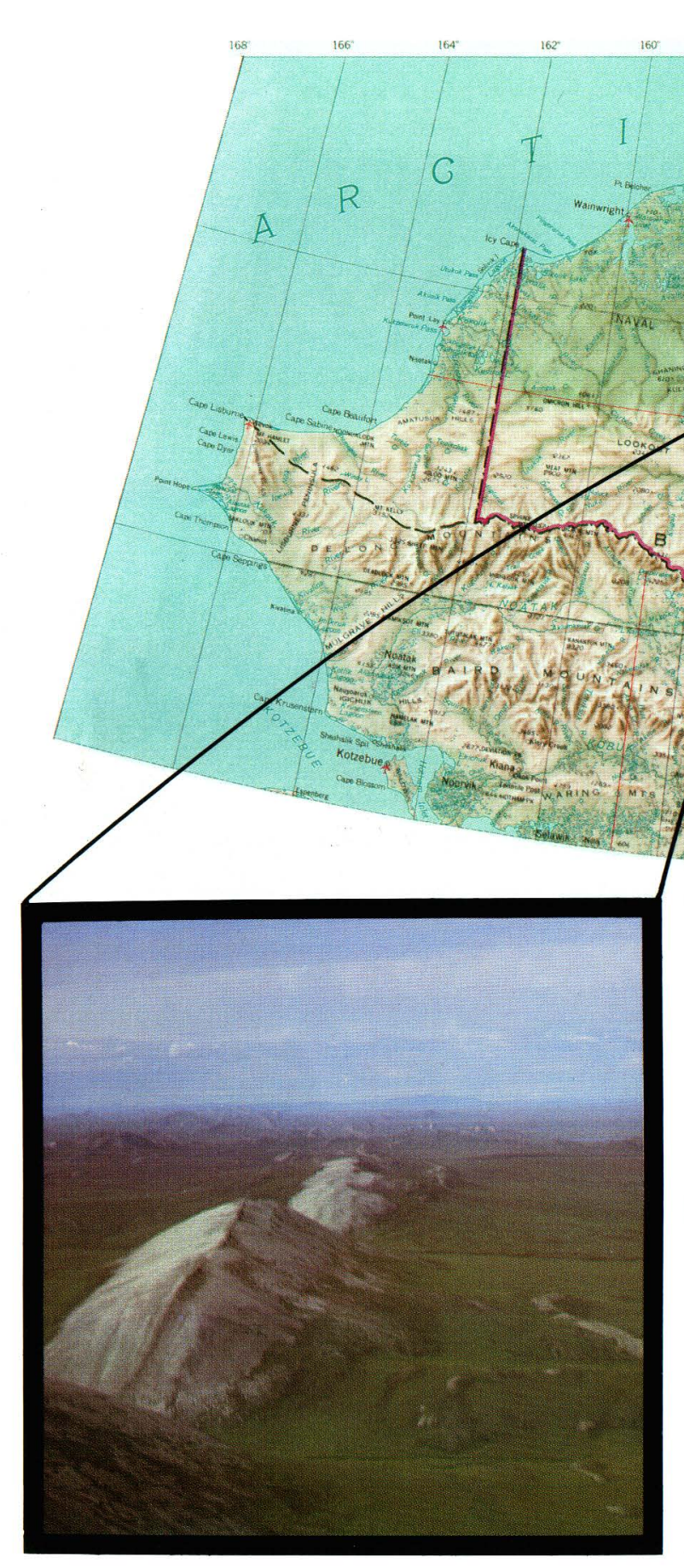

Folded rocks of the foothills region. Photograph by Irvin Tailleur.
The Ikpikpuk River winds across the Arctic Coastal Plain. Pho-

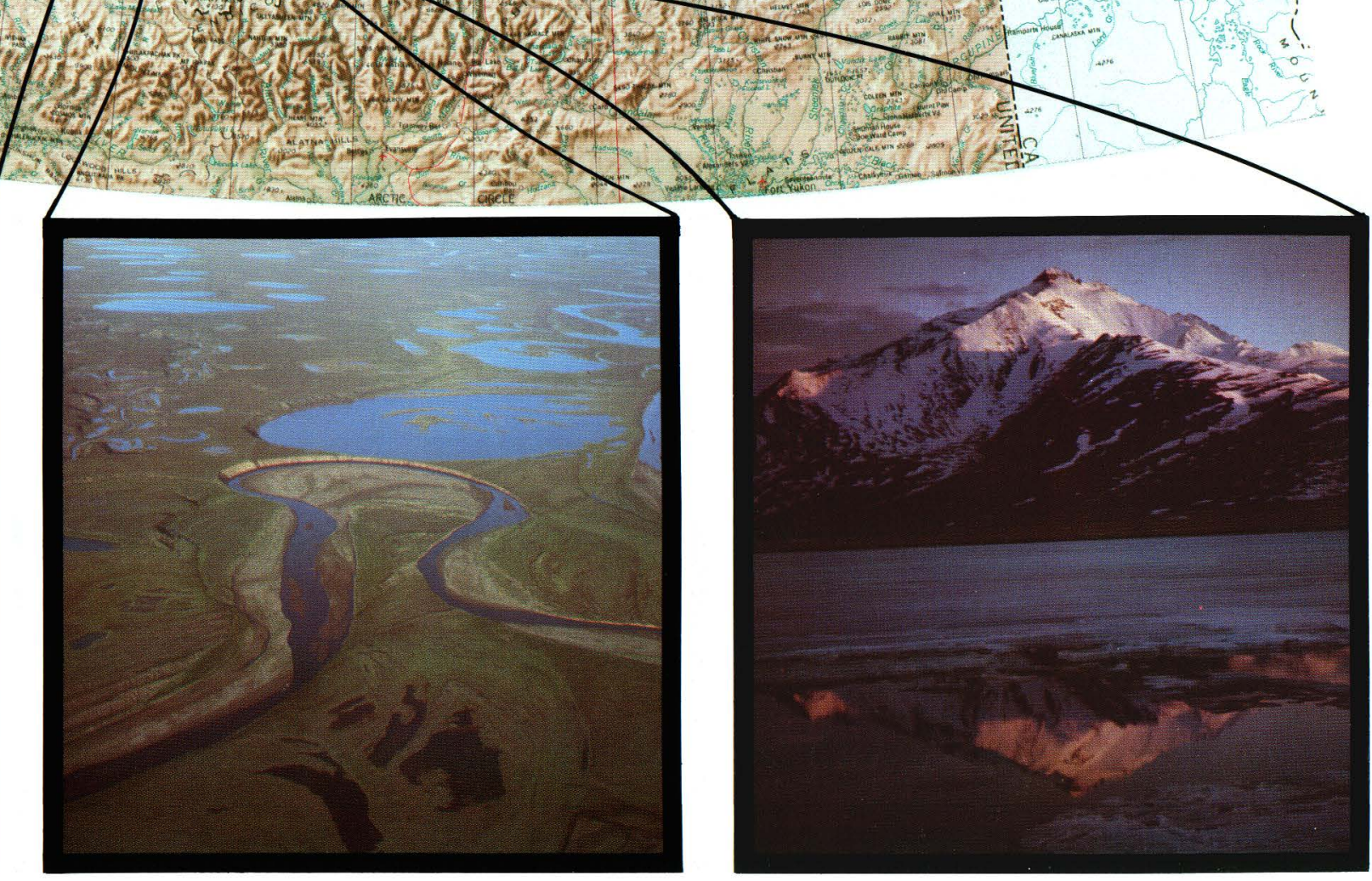
tograph by George Gryc.

Jagged, snow-capped mountains provide a backdrop for Chandler Lake, a glacial lake in the Brooks Range. Photograph by George Gryc. 


\section{Who and what live on the North Slope?}

Eskimos gather to celebrate a good whale catch near Barrow, about 1924. Photograph by Charles Brower.
Fewer than 4,000 Eskimos live within the NPRA. They are now concentrated in two coastal villages-Barrow and Wainwright-and two inland villages-Atqasuk and Nuiqsut - on the banks of the Meade and Colville Rivers. The NPRA lies entirely within the boundaries of the North Slope Borough. In Alaska, a borough is the political subdivision below State and replaces the county or parish subdivisions of other States. As such, the North Slope Borough is the largest "county" in the United States and actually is larger than most States. Other Eskimo communities in the borough are Anaktuvuk Pass, Kaktovik, Point Hope, and Point Lay. Some 2,000 oil-field employees and service personnel live and work in the Prudhoe Bay area. The total population of the borough is about 6,000 . The borough headquarters are in Barrow, the largest community on the North Slope.

Archeologic evidence from northern Alaska documents the presence of early inhabitants, possibly the Eskimo's ancestors, for at least the past 8,000 years. They were nomadic hunting people, follow ing sea mammals along the coast and caribou and other wildlife inland
The most abundant member of the present animal population is the brown lemming of migratory fame. The NPRA is also the home of the Arctic caribou, musk ox, moose, wolf, wolverine, fox, and barren-ground grizzly. Dall mountain sheep live in the bordering Brooks Range and nearby hills. Numerous birds visit the area during the short summer months, and thousands of waterfowl, ducks, geese, swans, and loons nest in the many lakes and ponds. No list of wildlife would be com plete without the ubiquitous mosquito, swarming in unbelievable numbers from early June to August Although the North Slope is commonly described as a flat treeless plain, small trees (willow birch, alder, and poplar) grow in some of the river valleys, generally only a few feet high but, in favor able places, as high as 15 feet. Flowering plants are abundant, blooming and fading quickly in the continuous summer sunlight. The tundra, a thick spongy matlike growth, is made up predominantly of grasses, sedges, mosses, lichens, and prostrate shrubs or bushes. Walking on this spongy tundra mat can be very tiring for humans.

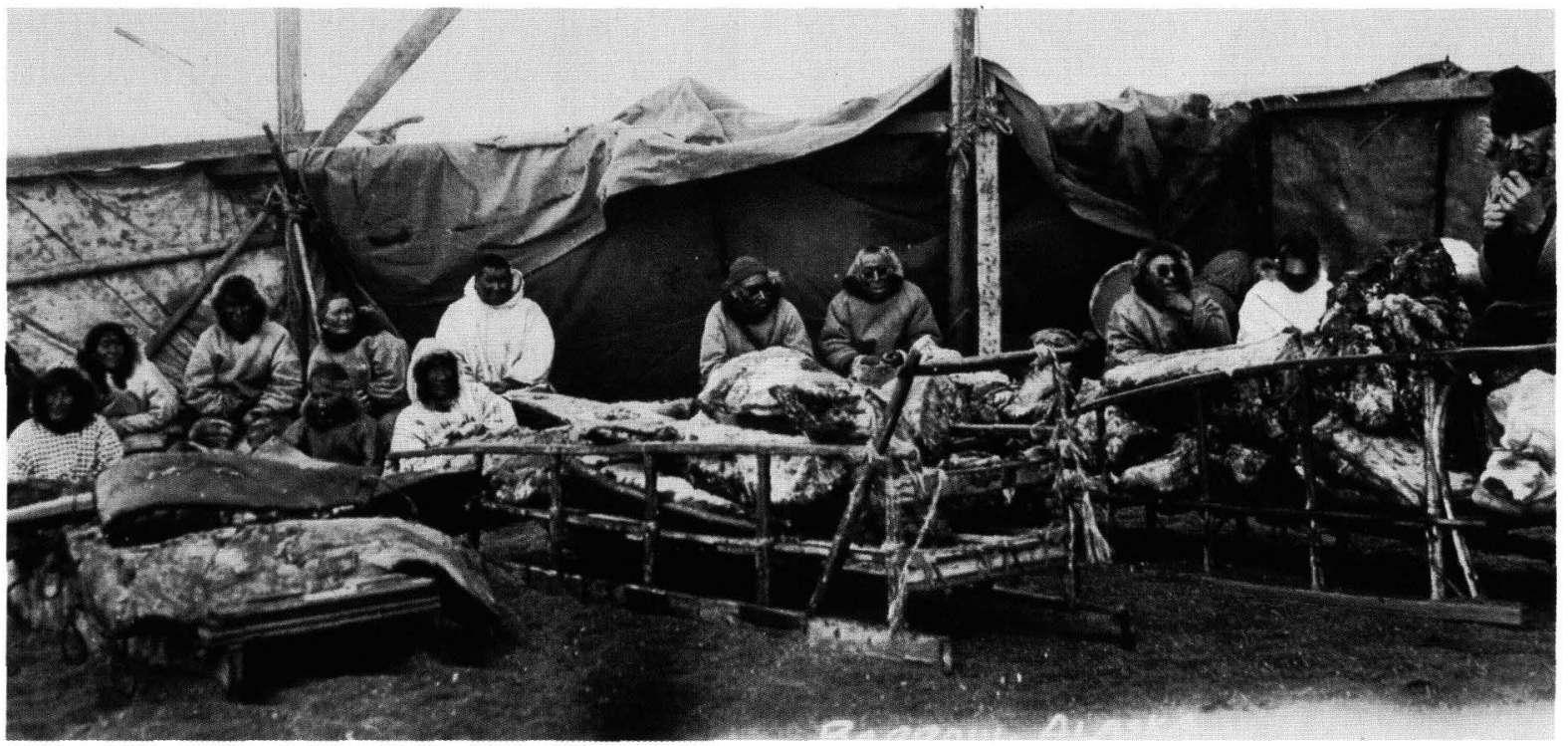




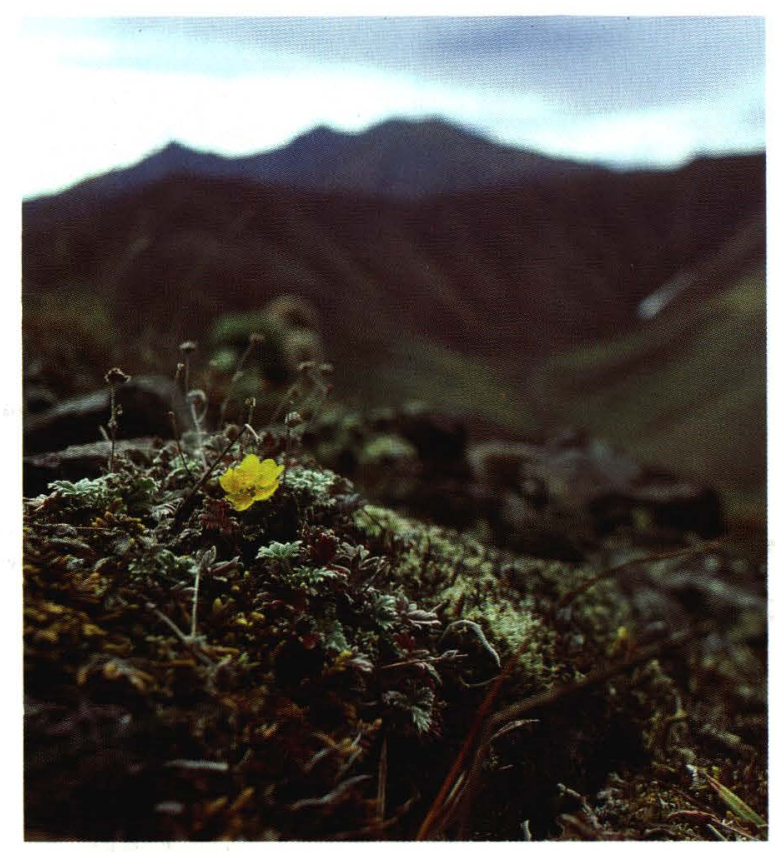

Flowers cling to the rocky slopes of the Brooks Range. Photograph by Jeep Johnson.

Caribou grazing in Arctic cottongrass, Eriophorum vaginatum. Each year, caribou migrate from south of the Brooks Range across the tundra to their calving grounds in the foothills and Arctic plains. Photograph by John Haugh.

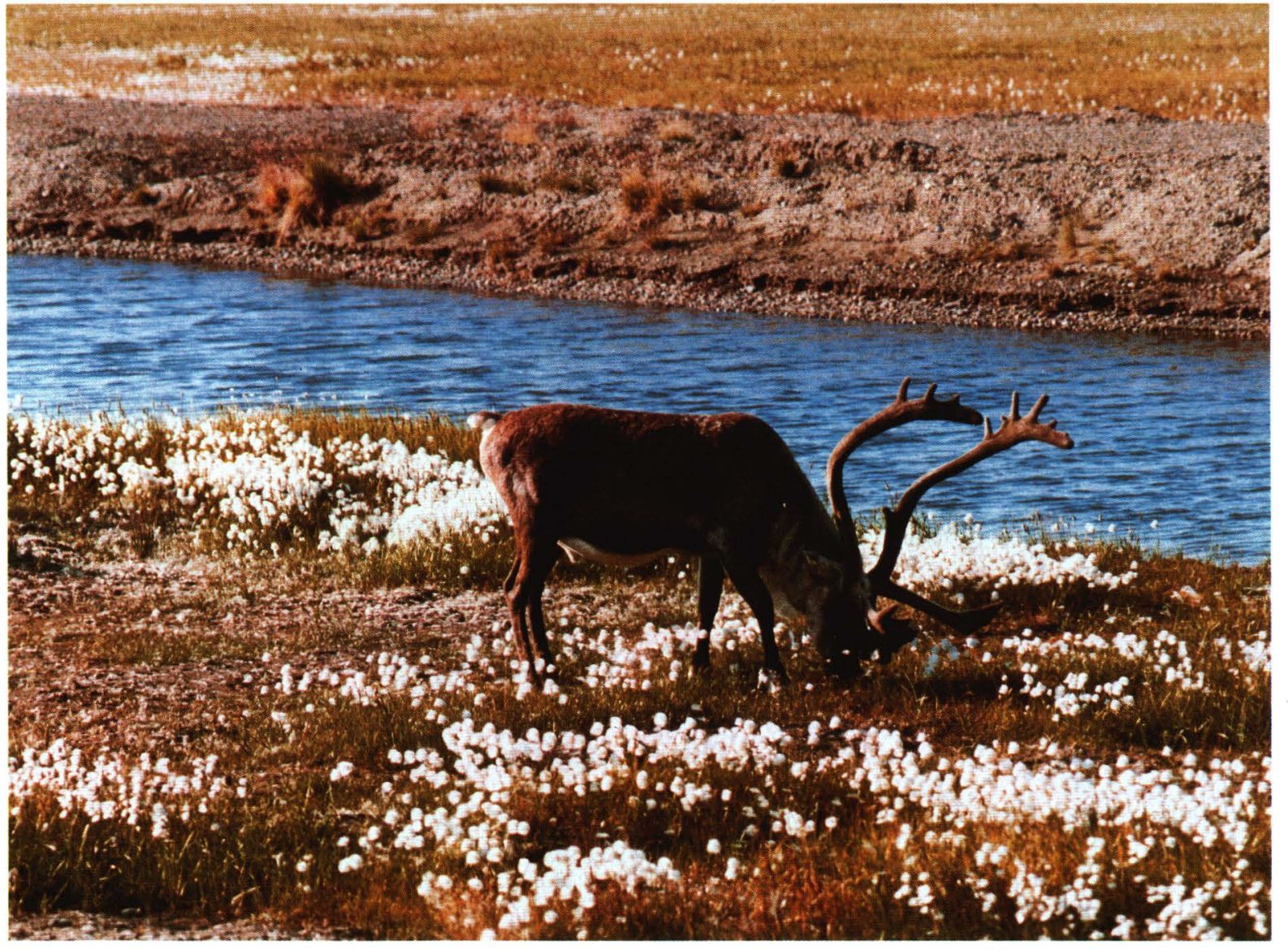

THE NATIONAL PETROLEUM RESERVE IN ALASKA 


\section{When, by whom, and how was the NPRA explored?}

\section{Early exploration}

Between 1800 and 1900, several hardy explorers sailed along the Arctic coast and described and named the major geographic features. Much of the sealane traffic, however, was by enterprising traders and whalers. It is interesting to note that the oil business, in one form or another, has had the greatest impact on the North Slope and its inhabitants.

The first big push to the Arctic was in search of whale oil, which, in the years before the Civil War, was the principal fuel for lamps and a common lubricant. The premium grade of fuel came from sperm whales, and the regular grade from bowhead and other species of whales. The rising industrialization of the United States and the heightened emphasis on education (requiring better light for evening study) created a rapid increase in demand In 1823, sperm oil sold for 45 cents a gallon, but by 1866 the price rose to $\$ 2.55$ a gallon - the first "oil shortage." The relief for this shortage came through the discovery and development of a more abundant and cheaper source of fuel, petroleum. Ironically, the next several waves of exploration and development in Arctic Alaska focused on a search for "rock oil."

In winter 1885-86, Lt. George M. Stoney participated in expeditions sponsored by the U.S. Naval Institute that explored the Brooks Range from the south. Ens. W. L. Howard of the U.S. Navy crossed the Brooks Range in 1886, and continued overland across the Colville River valley and thence down the Chipp River by skin boat to Point Barrow. He described what were undoubtedly lumps and pebbles of oil shale along the Etivluk River. His report published in 1900, may have been the first recorded suggestion of the oil potential of northern Alaska. However, this material and seepage tars had been known and used by the Eskimos before recorded history.

Frank C. Schrader, 1910. The first systematic survey of the North Slope was made in 1901 with Schrader as geologist and W. J. Peters, an experienced topographer and explorer, in charge. The geograph and geology of an entirely new section of northern Alaska were studied by Peters and Schrader, much of it in the NPRA area.

\section{Geologic and topographic surveys, 1923-26}

The first systematic topographic and geologic survey across the Brooks Range and the North Slope was by F. C. Schrader and W. J. Peters of the USGS in 1901; the results were published in 1904 in Professional Paper 20. Schrader described thick marine sequences and noted broad anticlinal structures-both of prime importance in the search for oil. Thus, by 1923 , when the lands were set apart, three of the prerequisites for the occurrence of petroleum were already known to be present: source rocks, such as organic marine deposits, including oil shale; potential reservoir rocks, including limestone and sandstone; and favorable structures, such as anticlines. In addition, oil

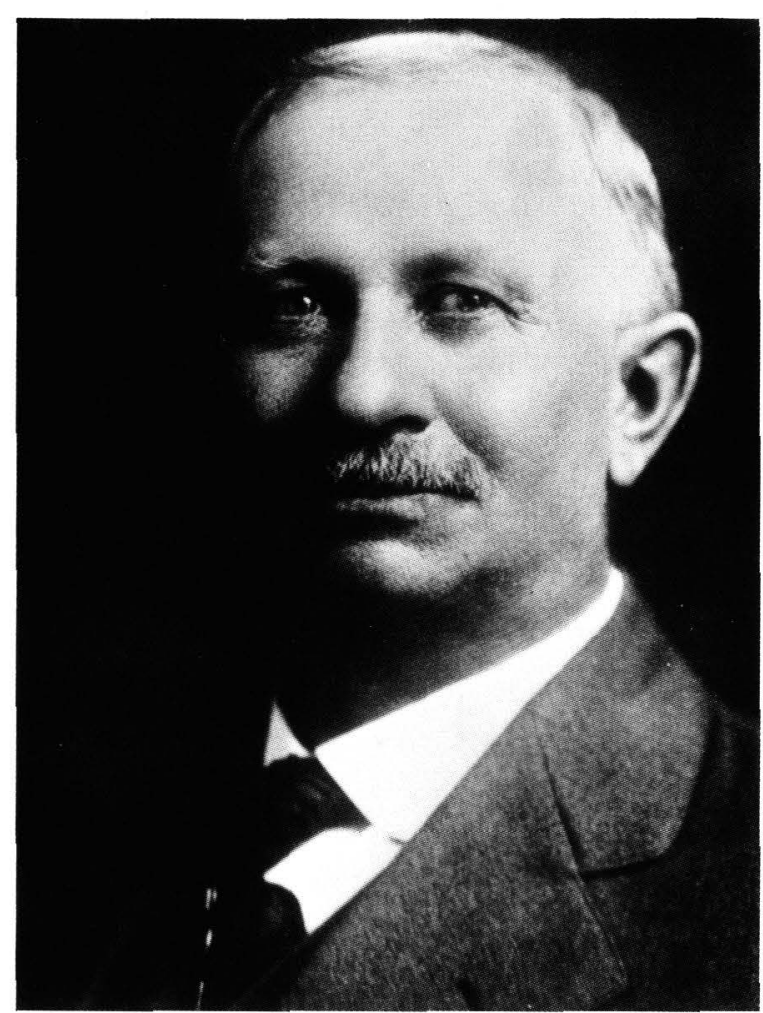


seepages were found along the Arctic coast. The region had already attracted the attention of the new oil industry, and several applications for prospecting permits were filed under the old mining laws on claims near Cape Simpson, Peard Bay, and along the Meade, Kukpowruk, and Kokolik Rivers.

About 150 miles east of NPR-4, E. de K. Leffingwell completed his classic work in the Canning River region. From 1906 to 1914, Leffingwell mapped the Arctic coast from Barrow to the United States-Canadian border. He named and described the now-famous Sadlerochit Group, which includes the primary oil reservoir of the Prudhoe Bay field. His report, published in 1919 as USGS Professional Paper 109, is now a collector's item. The region mapped by Leffingwell from the Canning River to the border was set aside in 1960 as the Arctic National Wildlife Refuge (ANWR).

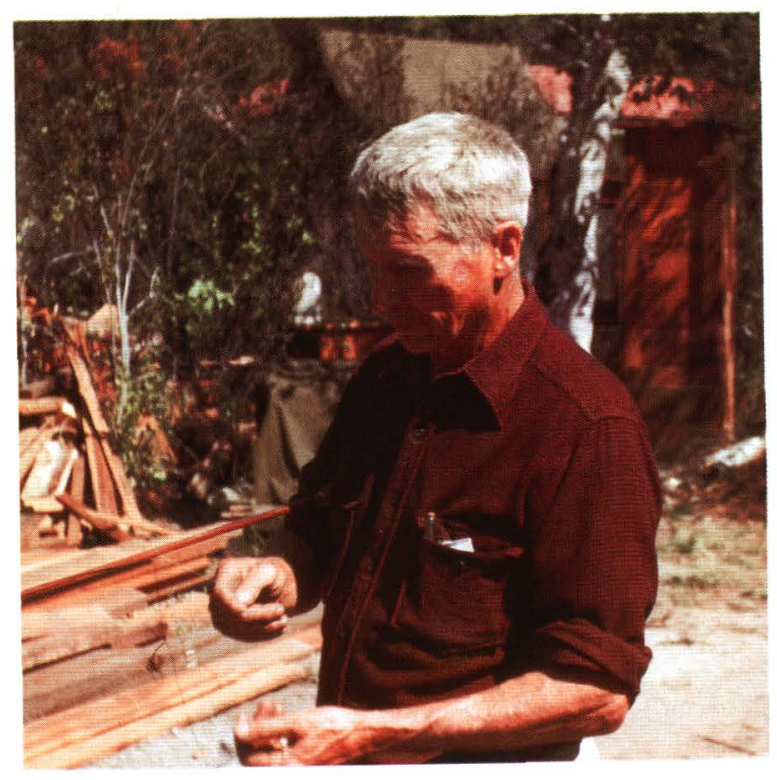

Ernest de K. Leffingzell. Between 1906 and 1914 Leffingwell mapped in the Canning River region from Barrow to the United StatesCanadian border. His expedition was privately funded, half by his father. Toward the close of his fieldwork, the USGS provided him with office space to write and compile his maps, and eventually published his work in 1919. Photograph by George Gryc.
Sketch map showing the progress of mapping, seismic surveying, and drilling from 1944 to 1953 (modified from Reed, 1958).

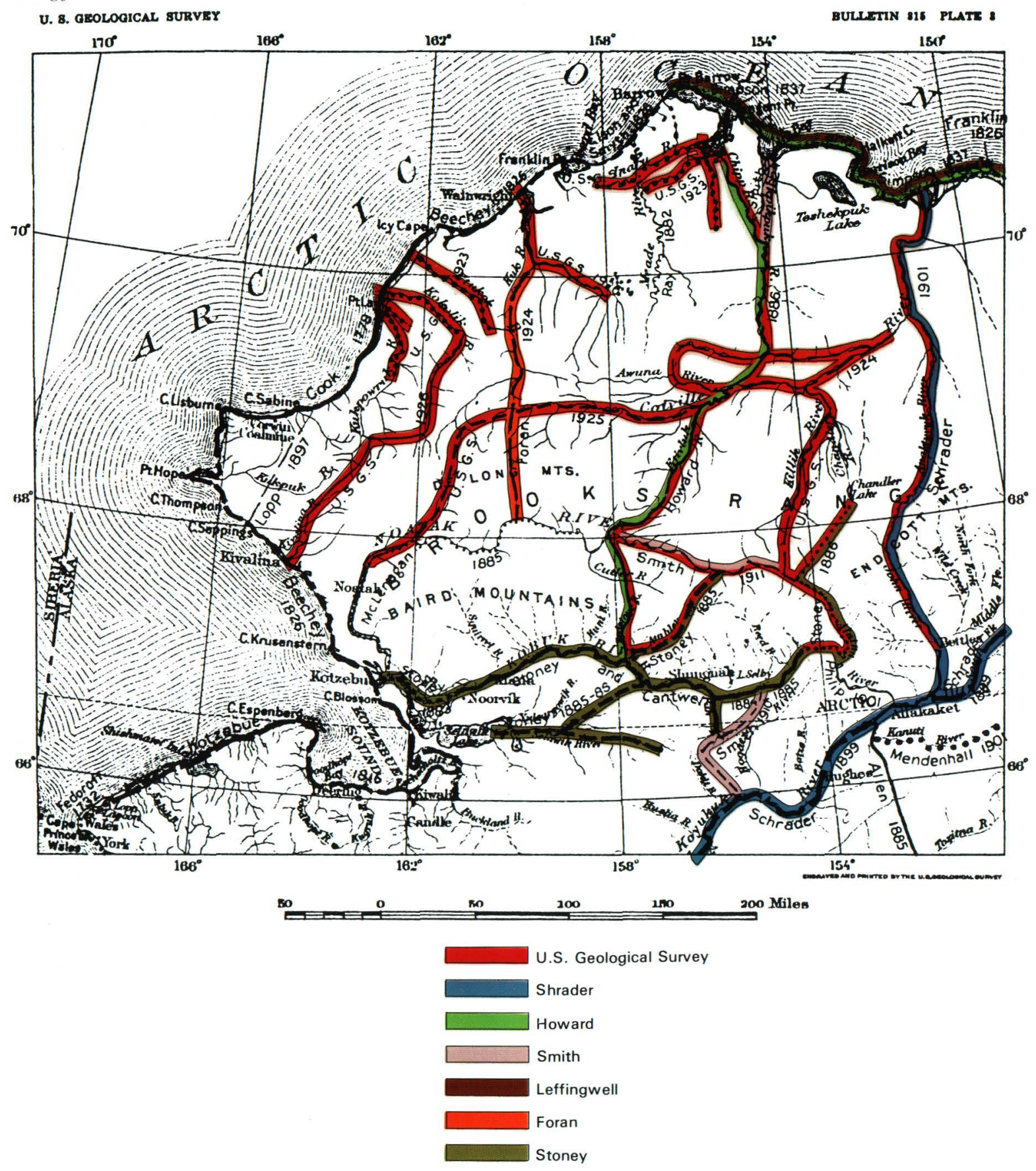

THE NATIONAL PETROLEUM RESERVE IN ALASKA 
The International Boundary Commission completed locating and marking the border between the United States and Canada in 1912, and additional geologic information was collected along it by USGS geologists attached to the mapping party.

Thus, the geology and geography of the east edge of this potential petroleum province were known and mapped in a general way before the establishment of the Reserve. However, there remained a virtually unknown gap, 130 miles wide, between the Canning and Colville Rivers. That area included the Prudhoe Bay oil and gas fields.

NPR-4 was defined, and its boundaries described, on the basis of explorations carried out before 1923. In delineating the Reserve, account was taken of the observations of oil seepages at Cape Simpson, the early explorations by the U.S. Navy (particularly Howard's traverses in the western area), and the traverse by Schrader and Peters along the Colville River-the east boundary of the Reserve. Although some detailed surveys had been made by Leffingwell and the United States-Canadian-boundary survey teams, their information was not considered to warrant a change in delineation of the boundary. Furthermore, the northwest coast of Arctic Alaska was more accessible by sea than the northeast coast.

Smith and Mertie party resting with dog teams along the Colville River, 1924. The first expedition started from Tanana on February 17, but it was not until April 2 that all supplies, including four specially built canoes, were safe in the first camp on the Arctic drainage, and it was May 30 before the streams were open enough to allow travel by canoe. Photograph by W. R. Smith.

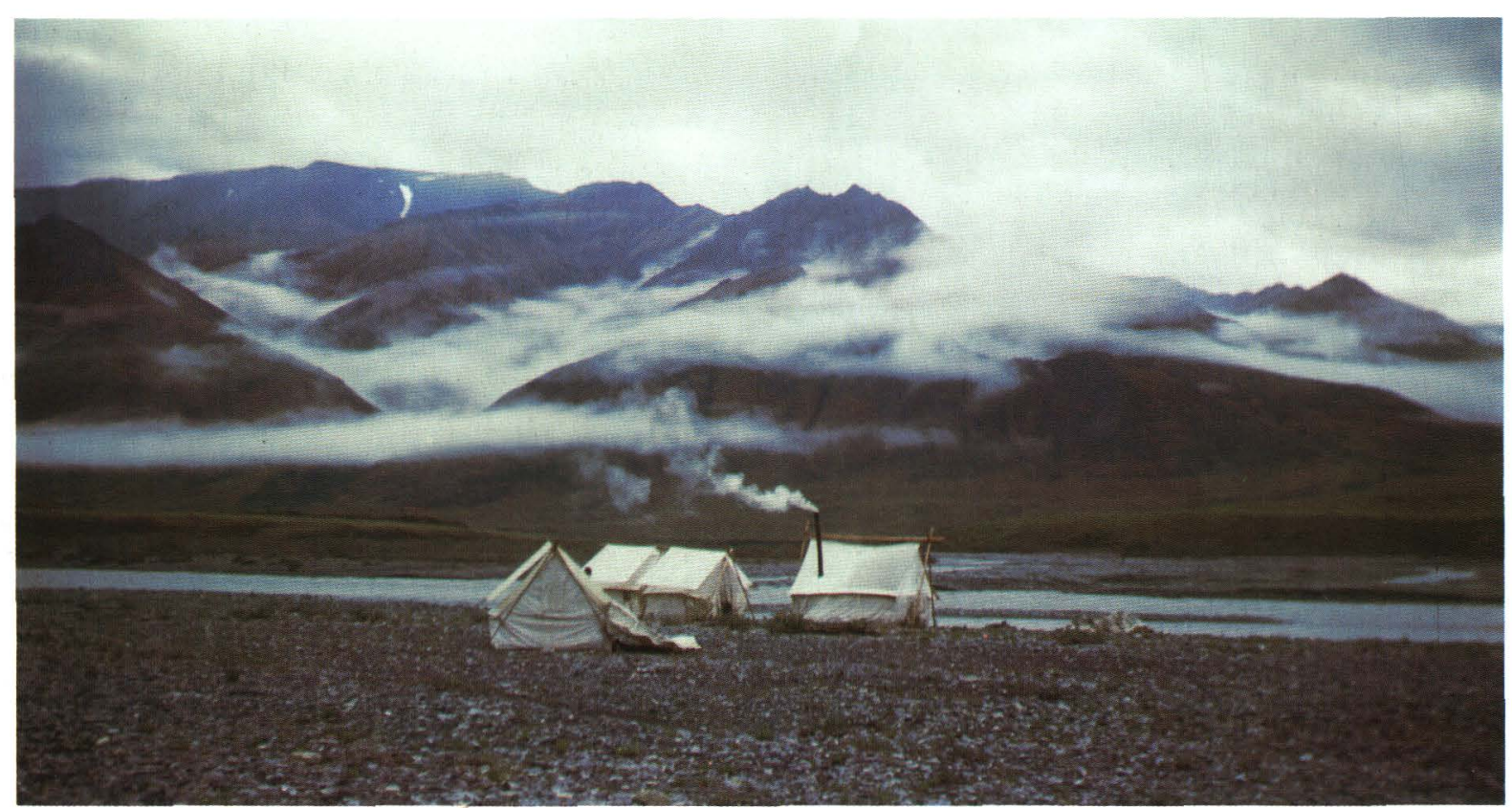

USGS surveying camp on the banks of the Canning River where Leffingwell worked. Photograph by George Gryc. 
In 1923 , little was known of the interior of the new Reserve. The U.S. Navy recognized that more geologic and geographic information would be required for proper management, and so the USGS was asked to survey the region. From 1923 through 1926, USGS parties traversed the Reserve along the major rivers and crossed the Brooks Range through Howard Pass and at the head of the Colville River. In 1930, the results of these field studies and surveys by P. S. Smith, J. B. Mertie, Jr., and others were published in USGS Bulletin 815. This classic report includes the first topographic and geologic maps of the Reserve, as well as descriptions of the rock sequences and structures, and an analysis of the mineral potential of the region, including petroleum and coal. Although the authors could not identify the precise age or distribution of the oil shales, they concluded that these rocks were the most likely source of crude oil. They felt that sources in Paleozoic rocks were "extremely problematic" and that, because the Cretaceous rocks were of shallow marine and terrestrial origin, oil deposits derived from them were "likely to be small and of extremely sparse distribution." Smith and Mertie noted the numerous anticlinal structures in the Cretaceous sequences, as well as the faulted and overthrust structures in the Paleozoic rocks of the Brooks Range, and concluded that the regional dip of the older rocks was monoclinal to the north. Thus, pre-Cretaceous rocks at Cape Simpson and along the Arctic coast would be below practical drilling depth. They recommended that the next steps in evaluating the petroleum possibilities should be drilling for stratigraphic and structural information in the vicinity of Cape Simpson, followed by geologic field studies, and then drilling in other areas that these studies might indicate to be favorable.

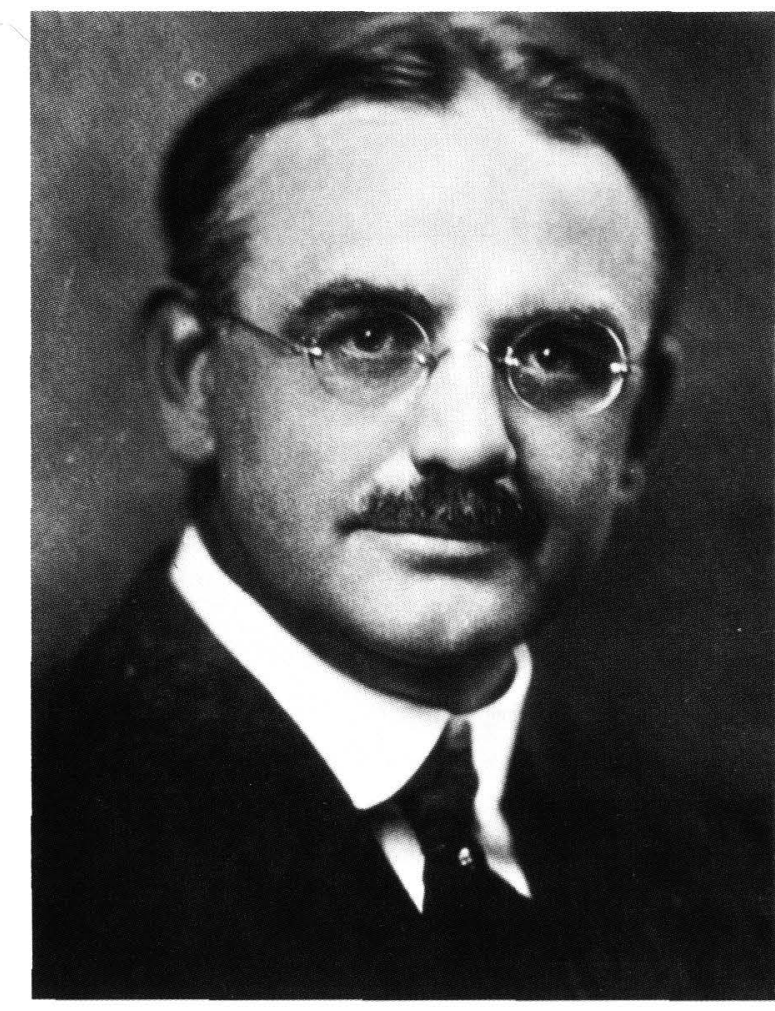

Philip S. Smith, about 1915. Smith was Chief Alaskan geologist from 1925 until he retired in 1946. At the request of the Department of the Navy, the USGS was included in the first explorations of the newly established NPR-4.

W. T. Foran field party in Noatak, about 1924. From left to right, $F$ W. Belgard, W. T. Foran, O. L. Wix, and H. G. Hughes. In 1943 , Lt. Foran called attention to the petroleum potential of NPR-4 as World War II brought an increasing demand for petroleum. Sparked by his encouragement, the first modern systematic oil-exploration program began in NPR-4 (1944 until 1953).

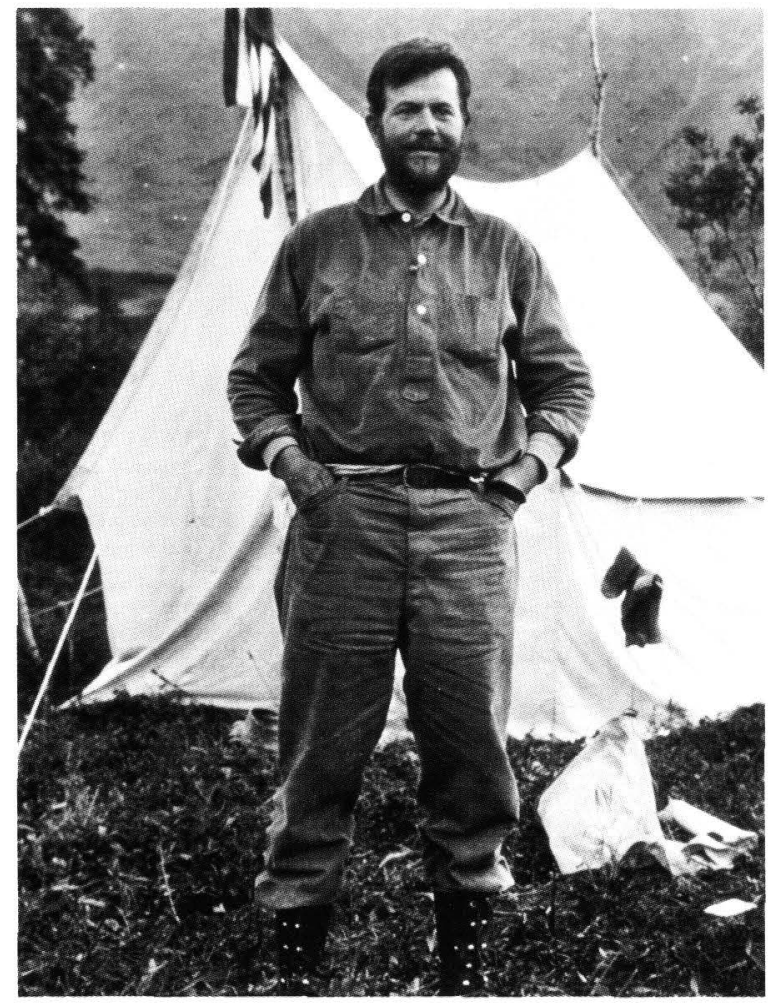

John Beaver Mertie, 1915. Mertie began his long geologic career with the USGS in 1908 and finished his last publication, a profes sional paper, in 1979. Along with Philip S. Smith, Mertie led the expedition into NPR-4.

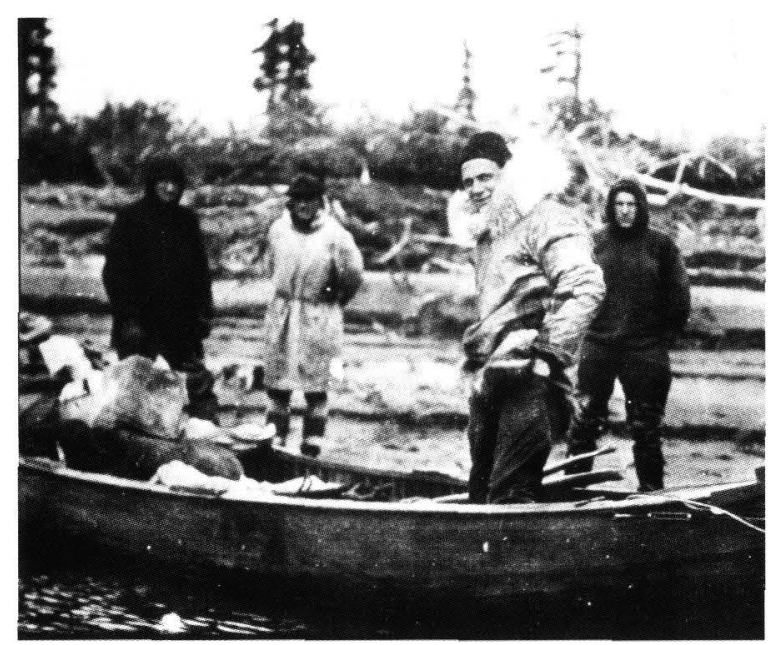




\section{The Pet-4 exploration program, 1943-53}

From 1926 to 1943 , little interest was shown in the petroleum potential of NPR-4. There was then no shortage of petroleum either for the U.S. Navy or for industry, and the remote and frigid Arctic was not an attractive target for commercial exploration. However, World War II brought a new perspective and an increasing demand for petroleum products to fight a highly mechanized war. In 1943, Lt. W. T. Foran, a former USGS geologist and a Naval Reserve officer, prepared a memorandum to the U.S. Bureau of the Budget, calling attention to the petroleum potential of NPR-4. Consequently, in 1943 the Secretary of the Interior issued Public Land Order 82, which withdrew from further entry all the possible petroleum areas of Alaska, including lands north of the drainage divide of the Brooks Range. Later in 1943 , the U.S. Bureau of Mines fielded a party to investigate and sample the known oil seepages and to check on reported seepages elsewhere in northern Alaska, including those on the Colville River at the base of Umiat Mountain. In early spring 1944, Lt. Foran made a quick reconnaissance of the Reserve, including the Umiat anticline, and reported that in his opinion a petroleum potential of major importance existed in NPR-4. On the basis of Foran's enthusiastic report and the perceived need for additional domestic oil supplies, a major exploration program, commonly called Pet-4, was started. This program had a tremendous impact on not only the future of petroleum exploration but also many aspects of life in the North American Arctic.

The Pet -4 program established the feasibility and practicality of carrying out large-scale modern oil-exploration operations in the Arctic, and developed many new techniques for such operations. During the period 1945 through 1952, 45 shallow core tests and 36 test wells were drilled in and adjacent to NPR-4. Public Land Order 82 and the addition of enabling appropriation language permitted exploration in adjacent areas. This drilling resulted in the discovery of oil deposits at

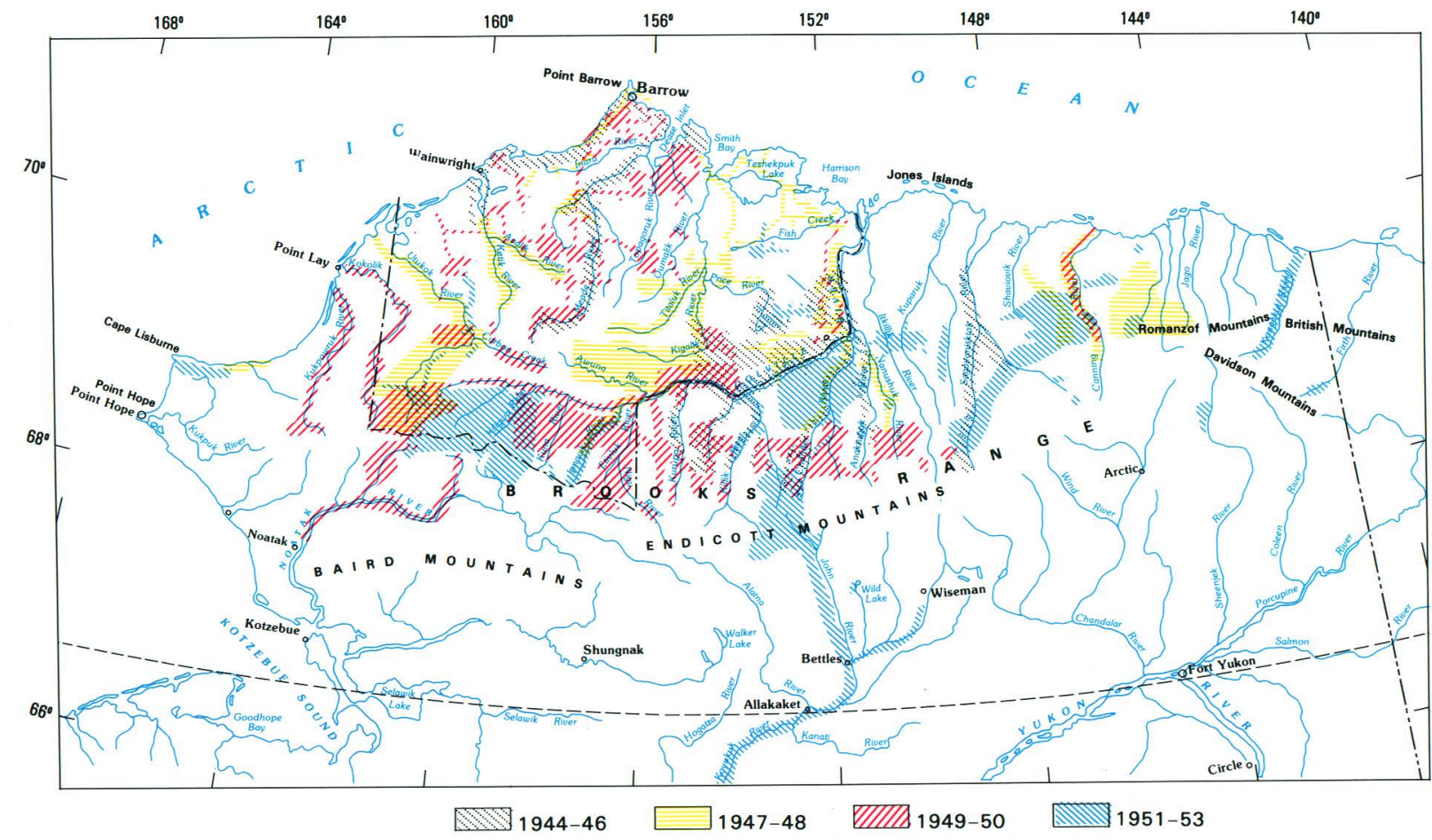

Progress of geologic investigations in northwestern Alaska (modified from Smith and Mertie, 1930).

Umiat, Cape Simpson, and Fish Creek, gas deposits at Umiat, Barrow, and Gubik, and prospective gas deposits at Meade, Square Lake, and Wolf Creek. Operating bases were established (and still exist) at Barrow and Umiat; the gas deposit at Barrow was developed, and gas was produced for use originally by the U.S. Navy base and other Government installations and, in 1964, by the entire Barrow community. The Pet-4 Barrow camp facility evolved into the Naval Arctic Research Laboratory, which was the hub of U.S. Arctic scientific investigations until it was decommissioned in 1981.

The USGS contribution to this program included surface geologic mapping of the Reserve and adjoining areas, study of subsurface samples and geophysical data, an airborne magnetic survey, interpretation of the geologic framework, assessment of potential resources, and production of the first complete set of planimetric maps of all of northern Alaska.

A series of reports on the Pet-4 program were prepared and published by the USGS as Professional Papers 301 through 305. They include a historical account, description of logistics and operations, well histories and descriptions, a geophysical report, and geologic maps and descriptions of the extensive surface mapping. Thus, a general geologic framework for all of northern Alaska became available for the first time. 


\section{The 1974-82 exploration of NPR-4/NPRA}

The discovery of oil and gas at Prudhoe Bay in 1968, in combination with the Arab oil embargo of 1974, stimulated the U.S. Navy to propose, and the Congress to approve, the next exploration program in the Reserve. Between 1974 and 1977, the Navy drilled seven test wells in the northeast corner of the Reserve, following the Prudhoe trend and hoping for similar results. The Navy also drilled four wells in the Barrow area and discovered the East Barrow gas field, thus providing an additional supply of gas for local use.

In 1975, the U.S. Navy signed a 5-year contract with Husky Oil NPR Operations, Inc., to manage and supervise all aspects of the exploration program.

In 1976, the Naval Petroleum Reserves Production Act (Public Law 94-258) authorized further development and actual production for sale of crude oil from NPR Nos. 1, 2, and 3 in California and Wyoming, and redesignated NPR- 4 as the NPRA. Thus, the purpose of these Reserves was redirected to augment domestic supplies of crude oil. The act also required studies of other resources and alternative management systems for NPRA. Responsibility for these studies and for continuation of the NPRA exploration program was transferred to the Secretary of the Interior, who, in turn, assigned to the USGS three duties: (1) furthering of the exploration program; (2) continuation of the operation, maintenance, and production of the gas fields at Barrow; and (3) cleanup of debris left from previous activities in and adjacent to the NPRA.
The USGS took over management of the program, including all contracts and facilities, on June 1, 1977. The primary objective of the exploration program was defined as an assessment of the oil and gas potential of the entire Reserve. A secondary objective was the discovery of commercially producible deposits. Thus, all tests were drilled "on structure," to the extent that this could be determined. A total of 28 test wells were drilled in the period 1974 to 1982 , of which 7 were under U.S. Navy management. One, the W. T. Foran test well and a followup, the J. W. Dalton test well, penetrated a section of favorable rock similar to that at Prudhoe Bay, but only shows (indications) of oil were found. Apparently, oil had accumulated in quantity at these localities but had subsequently migrated elsewhere.

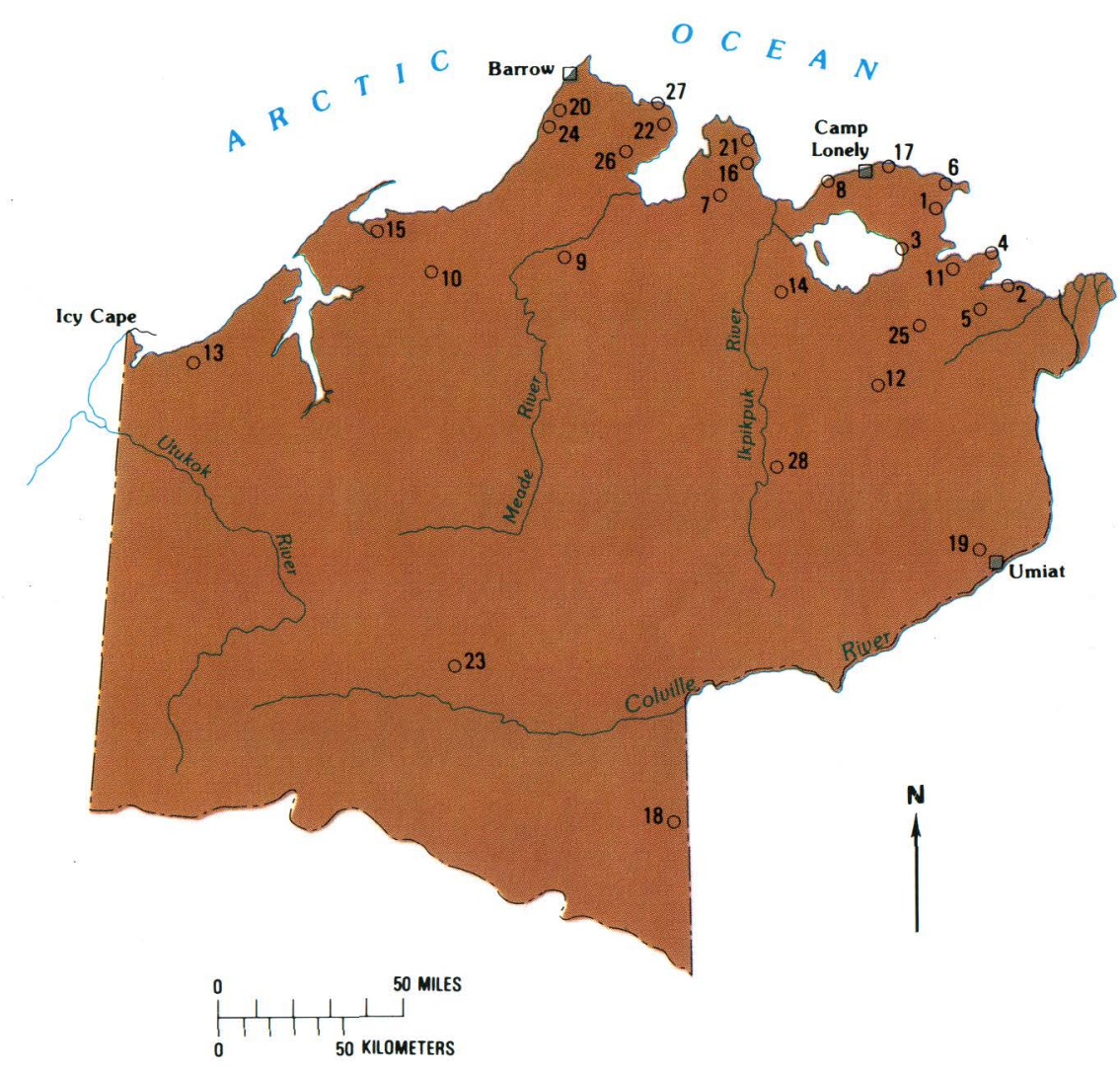

EXPLORATION WELLS 1975-1981

1. Cape Halket

2. S. Harrison

3. E. Teshekp

5. Atigaru

5. W. Fish Creek

6. W. T. Foran

7. S. Simpson

9. S. Meade

10. Kugrua

11. N. Kalikpik

12. Inigok
13. Tunalik

13. Tunalik

15. Peard

16. E. Simpson No.1

17. J. W. Dalto

18. Lisburne

19. Seabee

20. Walakpa No. 1

21. E. Simpson №.

22. W. Dease

23. Awuna

24. Walakpa No. 2

25. N. Inigok

26. Kuyanak

27. Tulageak

28. Koluktak

Exploration wells in the NPRA drilled from 1975 to 1981 (from

Mitchell, 1983 
Several test wells were drilled on the flank of the Barrow structure, and a new gas field was discovered at Walakpa, 14 miles southwest of Barrow. This deposit may be useful to the Barrow community but probably is of insufficient size to warrant development for export to the "South 48." Farther south on the downslope of the PrudhoeBarrow trend, test wells were drilled to explore the wedge edge of potential reservoir rocks, and two deep test wells were drilled near the center of the northern Alaska depositional trough. Additional test wells were drilled on anticlinal structures in the foothills, an area that had been drilled extensively in the Pet -4 program, but only for shallow horizons. One test well was drilled in the overthrust belt near the front of the Brooks Range. Nearly all these test wells produced shows of oil or gas, but no commercial deposits were discovered.

The congressional mandate to continue supplying gas to the Barrow community required drilling additional production wells in that area. Six wells were drilled, and four were completed for production.

The third duty of the USGS was to complete cleanup of the debris from earlier work within or adjacent to the Reserve. In addition, all the sites or "areas of operations" of the current program, as defined in a memorandum of understanding (MOU) with the U.S. Bureau of Land Management (BLM), had to be rehabilitated and revegetated. A cleanup program was started by the U.S. Navy in 1971 and was completed by the USGS in 1984. These sites have recently been returned to management by the BLM.

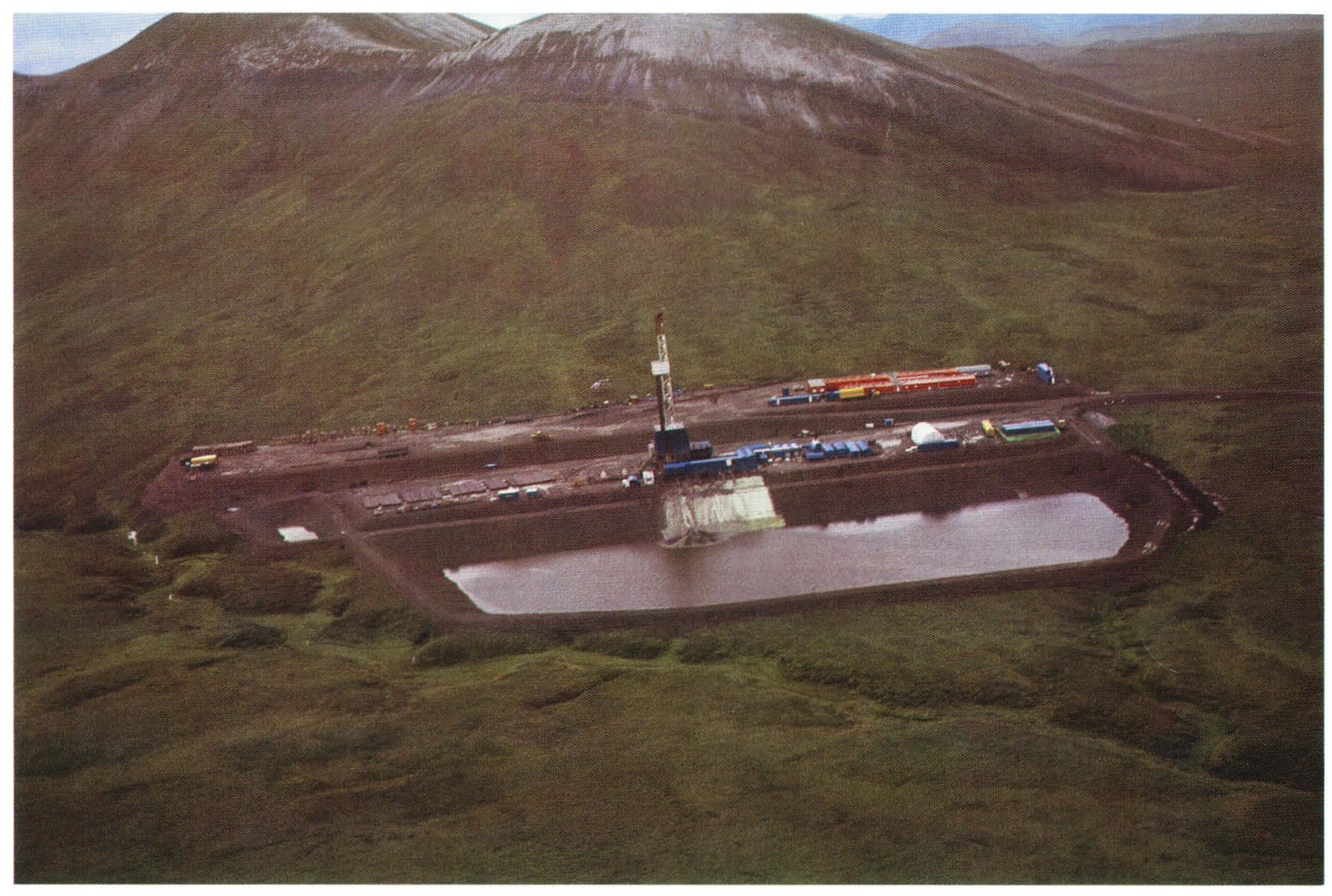

The Lisburne No. 1 test well, located in the southern part of the NPRA, was spudded in June 1979 and completed in June 1980 at a total depth of 17,000 feet. 


\section{Summary of significant events in the history of petroleum exploration in Alaska}

The history of petroleum exploration, development, and production in Alaska reflects an odd mix of Government exploration and assessment, Government regulation and land management, oilindustry interest, and market fluctuations. Federal exploration in the NPRA was concentrated largely in the three periods 1923-26, 1944-53, and 1974-82. In between, other events and publications influenced the course of petroleum development. The USGS had, and continues to have, a major role in this story. Some of the more significant events are:

\section{1 - Industry began petroleum exploration in Alaska.}

1902-33 - Oil discovered near seepages at Katalla; 154,000 barrels of crude oil produced.

1910-20 - Industrial activities slowed by Federal land withdrawals.

1923 - NPR-4 established by Executive Order

1923-26 - First exploration of NPR-4 by the U.S. Navy and USGS.
1920-40 - Industrial exploration intensified in southern Alaska; no major discoveries.

1941 - USGS report on possible oil provinces in Alaska by P. S. Smith, American Association of Petroleum Geologists (AAPG) Bulletin.

1951 - USGS report on possible future petroleum provinces by George Gryc, D. J. Miller, and T. G. Payne, 2nd AAPG Symposium.

1944-53 - Pet-4 program

1953 - All Pet -4 data released in USGS open files.

1957 - Swanson River, Cook Inlet field discovered by the Richfield Oil Corp.

1958 - Alaska Statehood Act and Public Land Order 82 rescinded; USGS begins publication of series of professional papers on NPR-4.

1959 - USGS Bulletin by D. J. Miller, T. G. Payne, and George Gryc on possible petroleum provinces in Alaska.

1960 - ANWR established.

1963 - Industrial exploratory drilling begins on the North Slope near NPR-4.

1964 - USGS report on mineral and water resources of Alaska by W. W. Patton, Jr., and others suggests possible Triassic-Permian sandstone reservoirs under coastal plain.
1968 - Prudhoe Bay oil field discovered by the Atlantic Richfield Corp.

1970 - National Environmental Policy Act, USGS report on thermal effects of heated pipeline on permafrost by $\mathrm{A}$. $H$. Lachenbruch has major affect on design of the Trans-Alaska Pipeline.

1971 - Alaska Native Claims Settlement Act.

1974 - Arab oil embargo; U.S. Navy renews exploration in NPR-4.

1976 - Naval Petroleum Reserves Production Act of 1976 (Public Law 94-258) transfers responsibility for the NPRA (formerly NPR-4) to the

Department of the Interior; exploration program assigned to the USGS.

1977 - Trans-Alaska Pipeline completed, and oil delivered to Valdez at the rate of 1.2 million barrels per day. Exploratory drilling near Prudhoe Bay continues; additional discoveries made.

1982 - NPRA program terminated

1982-83 - Lease sales in the NPRA; industry begins geophysical surveys.

1983-84 - Geophysical surveys permitted and begun in the ANWR.

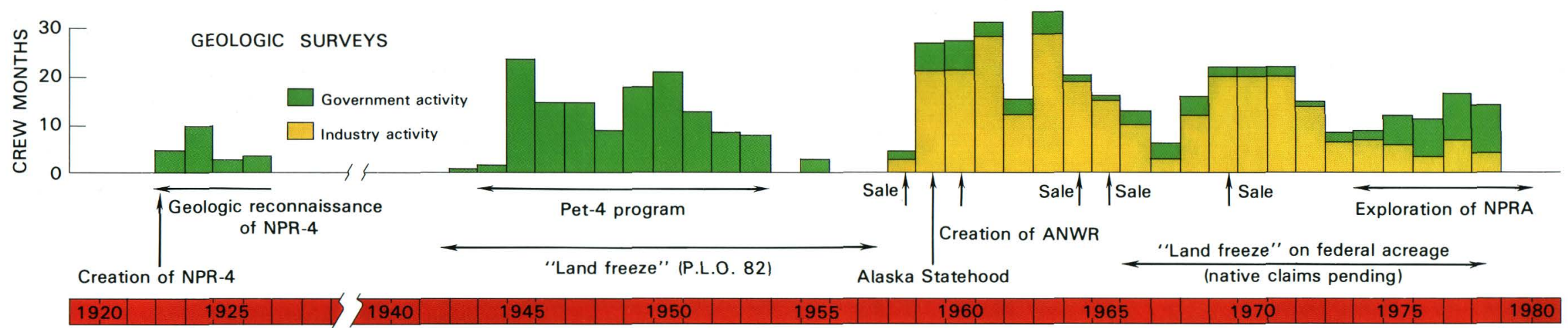





What are the
geological,
geophysical, and
geochemical factors
considered in
petroleum
exploration and
resource assessment?

In the late 1800's, during the early days of petroleum exploration, test wells were drilled only near obvious surface oil seepages. However, as the demand for oil grew and the difficulty of finding it increased, it became evident that a better understanding of the origin and location of petroleum deposits was essential. This quest for knowledge led to many investigations, ranging from the molecular structure of oil, through computer analyses of sound waves in the Earth, to how far a sand grain must travel to become well rounded. The results of such studies form the foundation of our present knowledge of petroleum and dictate modern exploration strategy.

We have learned that oil and gas are formed from the remains of microscopic plants and animals buried in sediment. Pressure and heat subsequently turn this organic material into oil and gas. For a valuable deposit to accumulate, porous rocks must be available to hold the newly formed oil and gas, a permeable layer must be sealed above by an impermeable layer to prevent escape, and a trap, such as a fold or fault, must be present to concentrate large amounts of oil and gas.

Thus, an exploration program must include a search for: (1) rocks containing organic source materials, (2) porous rocks to form a reservoir, (3) impermeable rocks to serve as a seal, and (4) oil or gas traps or stratigraphic trapping features. Before a drilling program is undertaken, the geologist must study the geologic history of the area and evaluate whether conditions are right for an accumulation of oil or gas. Such studies include geophysical and geochemical surveys, and evaluation of source rocks, reservoir rocks, and structural or stratigraphic traps. 


\section{Geologic history}

In general, the geologic history of the NPRA corresponds to that of the North Slope. From Mississippian through Triassic time, most of the region was below sea level and consisted of a broad stable shelf. The north border of this shelf was a large landmass, which supplied great volumes of sediment to the submerged continental shelf.

Theories abound concerning the origin of northern Alaska, but probably during Jurassic or Early Cretaceous time the Alaskan landmass rifted and pivoted around a point near the Mackenzie River delta. This rift created the Canadian Basin of the Arctic Ocean and caused the uplift of the Brooks Range mountain system. The northern source of sediment was thus eliminated, and a new sediment source was created-the Brooks Range to the south.

About the same time as or shortly after the Brooks Range uplift, there was a broad subsidence of the lands immediately to the north that formed the submerged Colville Trough. This sedimentary trough was partly closed to the north by a relatively stable border called the Barrow arch. This elongate bowl, the Colville Trough, rapidly filled with more than 6 miles of sediment derived from the newly formed and rapidly eroding Brooks Range. The trough was then uplifted, folded, and faulted during Cretaceous and early Tertiary time.

Since the early Tertiary, basin filling and deformation of that fill have shifted northeastward, so that the thickest Tertiary sedimentary deposits are in the northeastern part of the North Slope and offshore. Earthquake epicenters just offshore from the ANWR and tilted Pleistocene terraces onshore indicate that deformation continues even today.

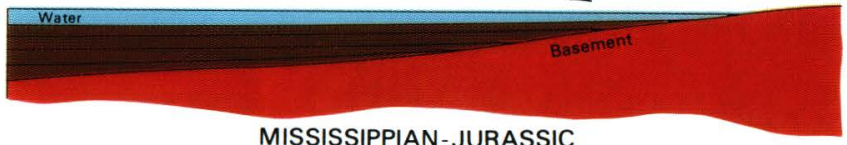

MISSISSIPPIAN - JURASSIC

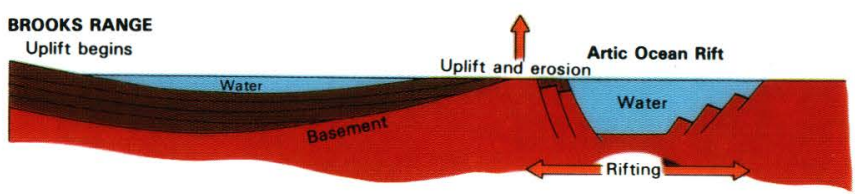

LATE JURASSIC-EARLY CRETACEOUS

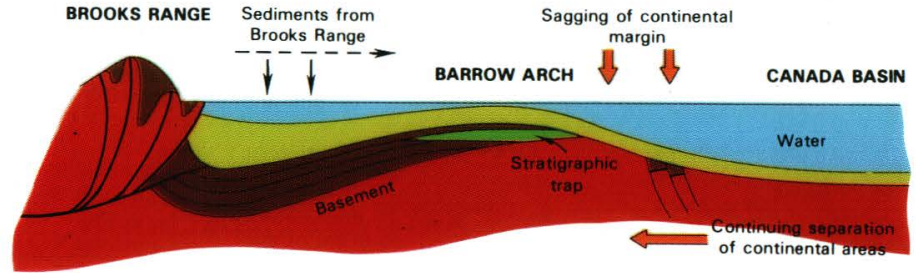

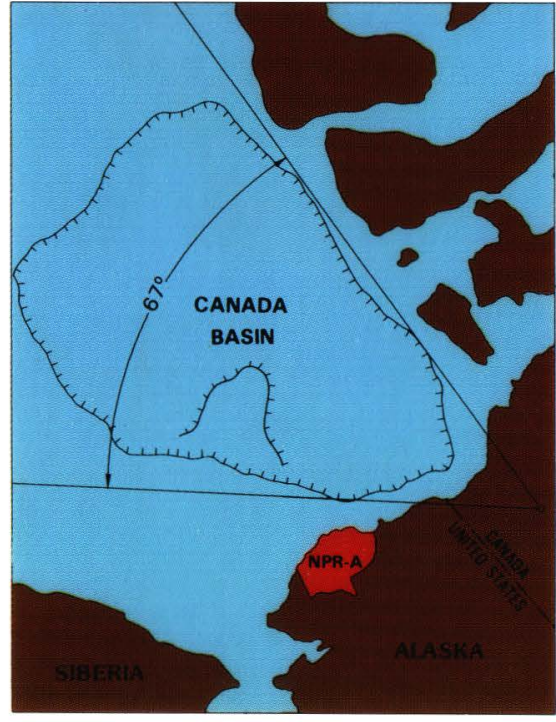

The geologic evolution of northern Alaska is depicted in these four cross sections. They depict a widely held theory that a sea-floor spreading center split the stable Canadian craton and that the northern Alaska plate rotated southward and westward to create the Brooks Range, the Colville Trough, and the Barrow arch (modified from Rickwood, 1970).

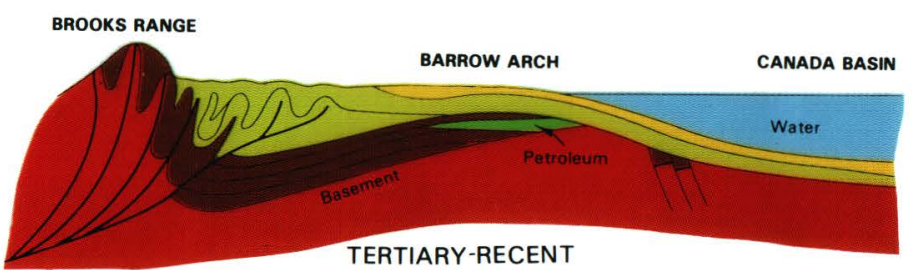

Franklinian Paleozoic sediments

Ellesmerian Paleozoic and sediments

Brookian Mesozoic sediments

Brookian Cenozoic sediments

Oil and Gas

The Canada Basin probably formed by rifting of the once-stable continental shelf of the Canadian craton, and then by pivoting approximately $67^{\circ}$ about a point near the McKenzie River delta. What controls rift-zone locations is not fully understood. Possibly, molten magma deep within the Earth creates zones of weakness beneath the continents and oceans (modified from Tailleur, 1983). 


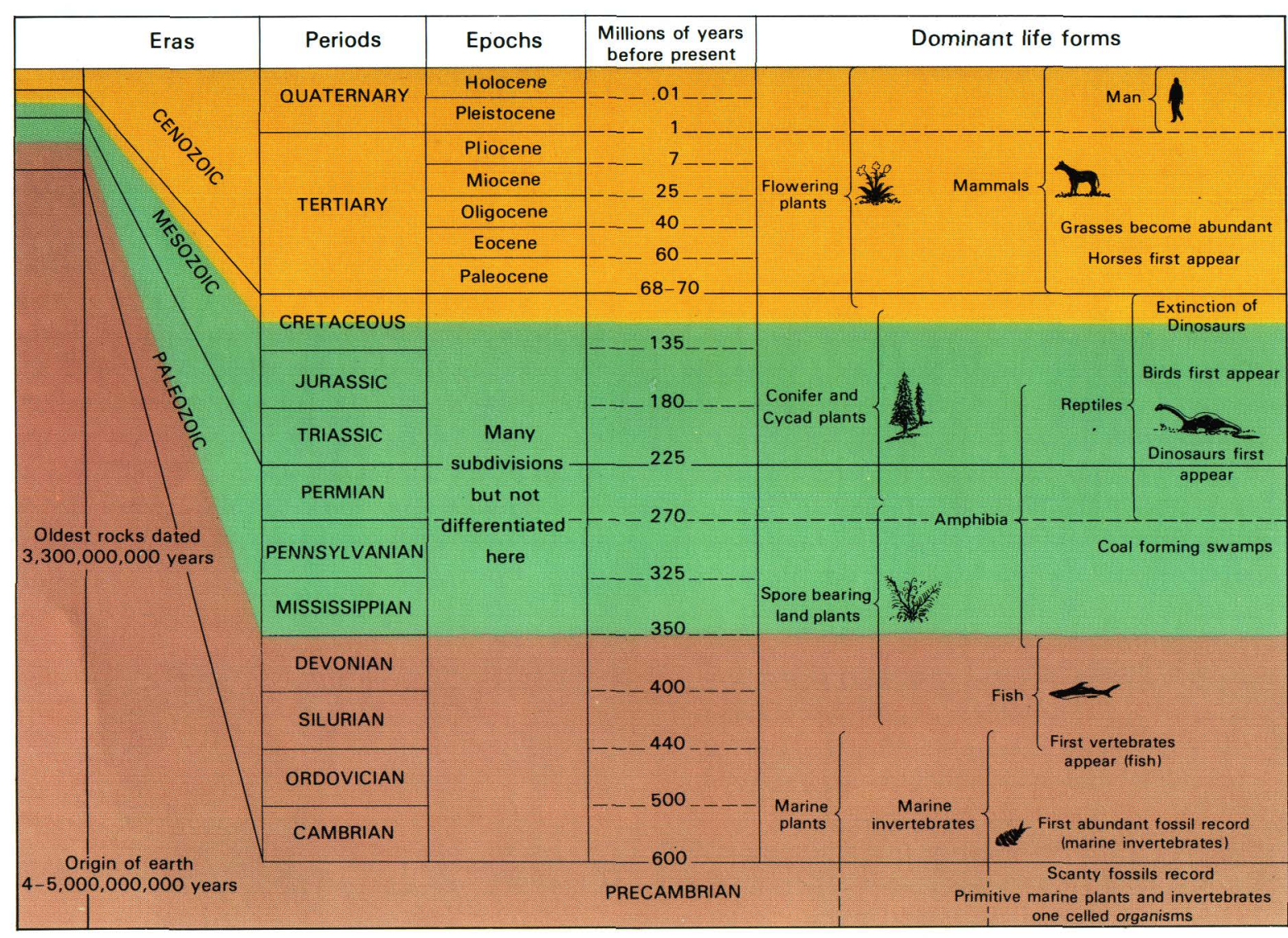

$\square$ Brookian sequence

$\square$ Ellesmerian sequence

$\square$ Franklinian sequence
A geologic column shows the divisions of time throughout the Earth's history. These divisions, based on the evolution and extinction of different life forms, also tend to reflect major tectonic events around the world. Three North Slope sedimentary sequences, the Franklinian, Ellesmerian, and Brookian, correspond, respectively, to preMississippian metamorphic basement, sediment derived from the north, and sediment derived from the south. 


\section{Structural elements and stratigraphic sequences}

The present geologic framework of the NPRA is composed of three distinct major physiographic and structural provinces and comprises three stratigraphic sequences (related packages of sediment). From north to south, these physiographic provinces are: the Arctic Coastal Plain, the foothills, and the Brooks Range mountain system. These provinces generally reflect the structural elements from north to south: the Barrow arch and the Arctic platform, the Colville Basin, and the Brooks Range thrust belt. The stratigraphic sequences within the NPRA subsurface are separated into the Franklinian rocks of pre-Mississippian age, the Ellesmerian rocks of Mississippian to Early Cretaceous age, and the Brookian rocks of Early Cretaceous to Holocene age.

The Franklinian rocks form the uneven basement of the Barrow arch and the Arctic platform. This platform dips regionally south from the Barrow arch and reaches its greatest depth beneath the Brooks Range front, where the overlying sedimentary pile is thickened by imbricate thrust faulting. The platform also dips gently east and west from the north-south-trending Meade arch, which bisects the NPRA. The diversity of structural trends in the basement suggests a complex deformational history. North of the Barrow arch, the Franklinian rocks of the Arctic platform dip beneath the Beaufort Sea shelf and form a series of block-faulted steps that descend into the Canada Basin.

Uplift of the Barrow arch and the Fish Creek platform (a complementary structural high south of the Barrow arch) during mid-Cretaceous time created three unusual catastrophic structures. West of the Fish Creek platform, a deep submarine landslide of about 1,200-square-mile area was formed. Across the central segment of the Barrow arch, a submarine canyon, about 40 miles long and as much as 5,000 feet deep-slightly smaller than the Grand Canyon-was eroded in Lower Cretaceous sandstone and shale and later backfilled with Upper
Cretaceous shale. On the crest of the Barrow arch, near Point Barrow, is an unusual circular, faulted and uplifted feature called the Avak structure that probably also formed during mid-Cretaceous time. The core of this structure contains chaotic (strongly disrupted) rocks of Jurassic and Early Cretaceous age. The origin of the structure is unknown. Although it has the structural form commonly attributed to meteorite-impact craters, there is no evidence for high temperature and pressure, and no evidence of meteoritic material. The Avak structure is surrounded by small dome-shaped features. To the east and west, these features are sealed by the faulted and uplifted rim, trapping and forming the Barrow gas fields.

In the subsurface, beneath the foothills and above the Arctic platform, is a southward-thickening wedge of sediment-the Brookian and Ellesmerian sequences. The younger Brookian rocks are deformed in a wrinkled-carpet pattern of east-westtrending thrust-faulted folds, whereas the older sequence below is relatively undeformed.

The southernmost margin of the NPRA includes the north edge of the Brooks Range thrust belt. This area contains sedimentary rocks that are folded and faulted into imbricately stacked thrust sheets. These thrust sheets are believed to represent largescale tectonic transport and crustal shortening by the underthrusting that formed the Brooks Range.

The oldest stratigraphic sequence, the Frank. linian sequence, consists mostly of metamorphosed sedimentary rocks that are complexly deformed and, in some places, intruded by granite and other types of igneous rock. These rocks form the Arctic platform and the basement beneath the Colville Trough (as far as we know).

The Ellesmerian sequence in the NPRA and Prudhoe Bay area includes sedimentary rocks of both marine and nonmarine origin that were derived from a northern continental source. This sequence is thickest to the north of the center of the Colville Trough. The early Ellesmerian rocks consist of a wide array of nonmarine coal-bearing sandstone, shale, and conglomerate of the Endicott Group, overlain by a blanket of marine-shelf limestone, dolomite, and shale of the Lisburne Group. MidEllesmerian strata include a sheetlike package of mostly silty and sandy marine-shelf sedimentary rocks and some limestone of the Sadlerochit Group, the Shublik Formation, and the Sag River Sandstone Late Ellesmerian strata are mainly deeper water marine shale and mudstone of the Kingak Shale and the pebble shale unit. Although these shale units and their associated sandstone and siltstone beds are generally believed to have been deposited in a shallow marine-shelf setting, they have some of the characteristics of large fans deposited in a relatively deep basin.

The Brookian sequence, of Early Cretaceous to Holocene age, consists mainly of deposits derived from the rising Brooks Range and dumped into the Colville Trough. Each successive sedimentary unit prograded northward and eastward across the Arctic platform and eventually overtopped the Barrow arch. The upper Brookian rocks of the Nanushuk and Colville Groups are delta-plain sandstone and shale-marine in the east and nonmarine and coal bearing in the west. 

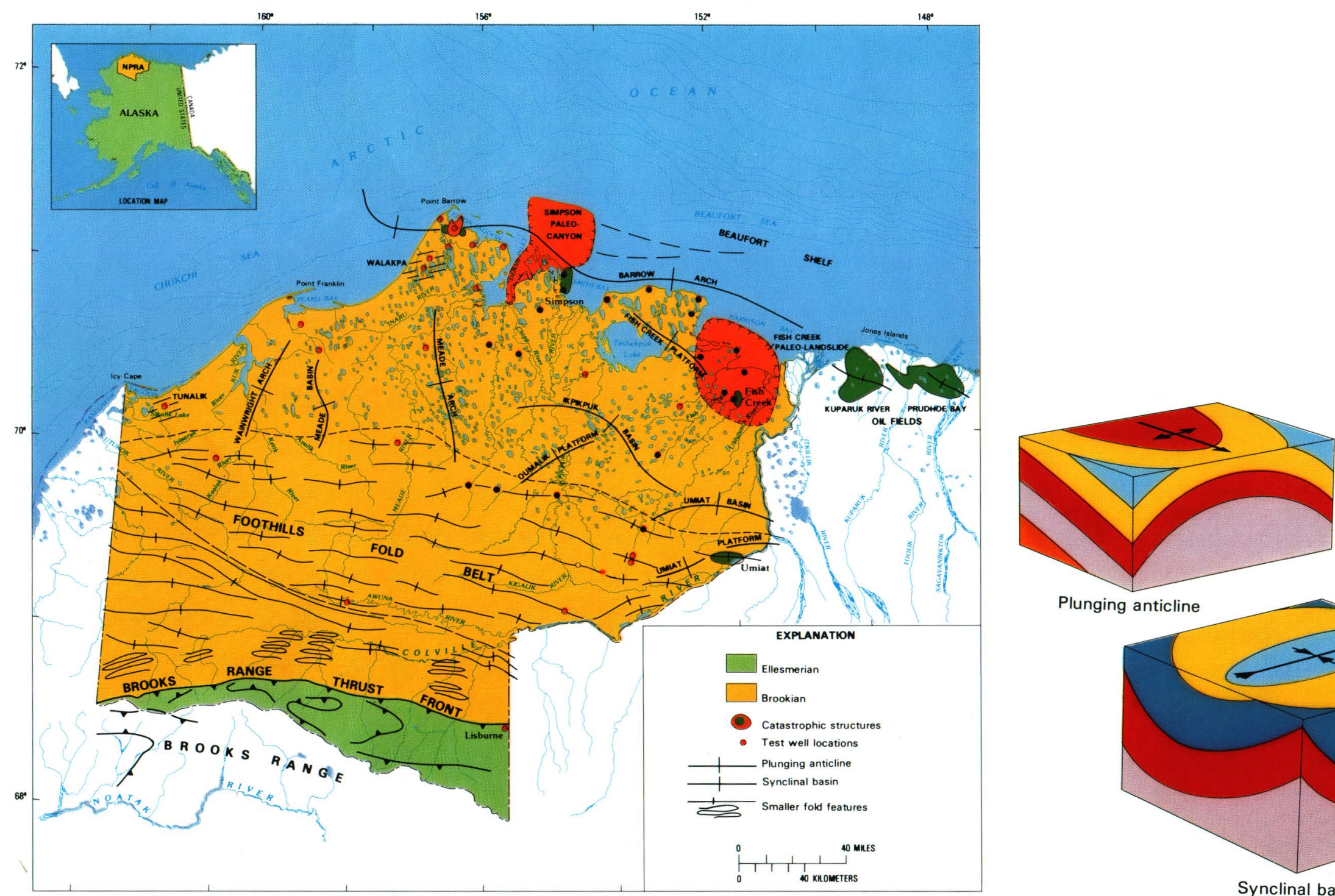

Plunging anticline

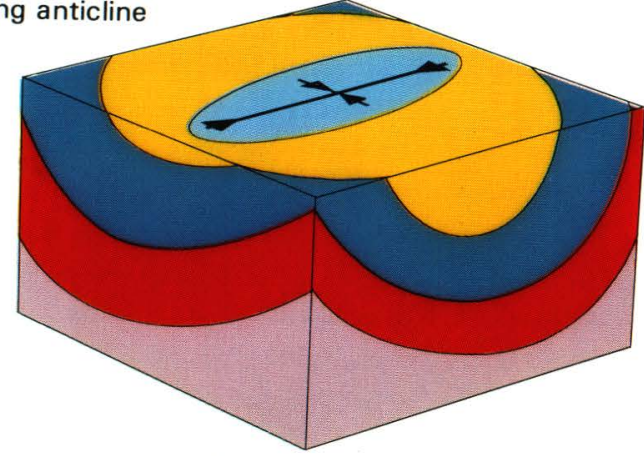

Synclinal basin

Geologic and structural map of the NPRA, showing the physiographic provinces, the Arctic Coastal Plain, the Foothills fold belt, the Brooks Range, and the surface distribution of Ellesmerian and Brookian rocks. The older Franklinian rocks do not crop out in the NPRA but are found farther south in the Brooks Range. The degree and complexity of folding increases from north to south. Large gentle folds beneath the Arctic Coastal Plain and part of the northern foothills form broad basins and wide arches where oil and gas may be trapped and held. 


\section{Subsurface geology}

\section{Geophysical surveys}

Geophysical prospecting supplies important data about the subsurface without drilling a well Three geophysical methods or surveys were used during the study of the NPRA-gravity, magnetic, and seismic reflection. Gravity surveys measure the Earth's gravitational field, which is modified by the thickness, variation, and distribution of rock types in the Earth's crust. Very slight variations in the gravitational field are commonly related to changing subsurface conditions and may indicate a deeply buried fault or anomalous body of rock. Magnetic surveys measure the Earth's magnetic field. Variations in this field indicate the presence of rocks in the subsurface that have high or low magnetic properties. Because most sediment is nonmagnetic, this survey provides information mainly on the composition of the underlying basement rocks. Seismic-reflection surveys are based on an analysis of sound waves artificially generated in the Earth and then reflected from various rock layers back to the surface. All three methods gather remotely sensed data; that is, geologic interpretations about the subsurface are based on indirect evidence-the actual rocks have not been seen.

Of these three methods used in the NPRA, the data from seismic-reflection surveys are the most specific, are quantifiable, can be corroborated with drilled wells, and generally (or if structure is not too complex) provide a clear visual representation of the subsurface in the form of a cross section. This method, however, is also by far the most expensive of the three. Gravity data, in contrast, were collected by the seismic surveying crews for only a small additional cost. Magnetic data were collected by towing a magnetometer behind a low-flying airplane. This method was used mostly during the late 1940 's and has not been a major part of the recent USGS NPRA project, although in selected areas very low level aeromagnetic surveys were flown. Their purpose was to detect near-surface magnetic anomalies related to leaking oil or gas.
Seismic profiles are produced by setting off a small charge of explosives in a shallow drill hole (rarely more than 100 feet deep) or by large vibrators that send shock waves or "acoustic signals" deep into the subsurface. These shock waves travel through sedimentary-rock layers and gradually lose energy with depth. At certain boundaries where these rock layers have different acoustic properties, some of the energy of the shock waves is reflected back to the surface. This returning acoustic signal, or echo, is received at the surface by a series of geophones-sensitive detectors spaced along a straight line-and electronically transferred into a printed seismic record.

Seismic "trains" work during the winter months and gather data about the subsurface rock layers. Photograph by John Schindler.

Inside the seismic-recording trailers are rows of computer monitors, magnetic tapes, and recorders that plot the actual profile. Photograph by Jeep Johnson.

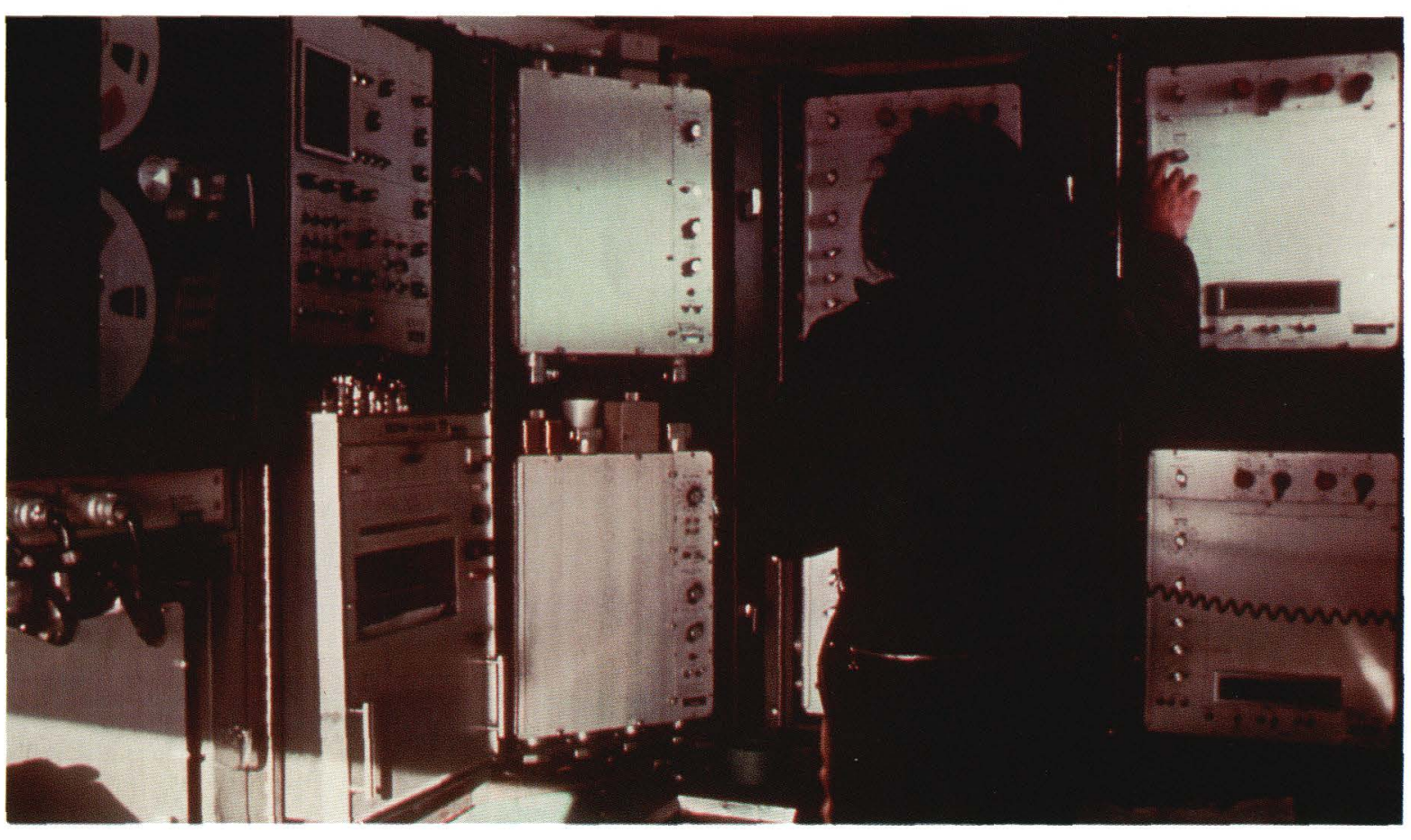




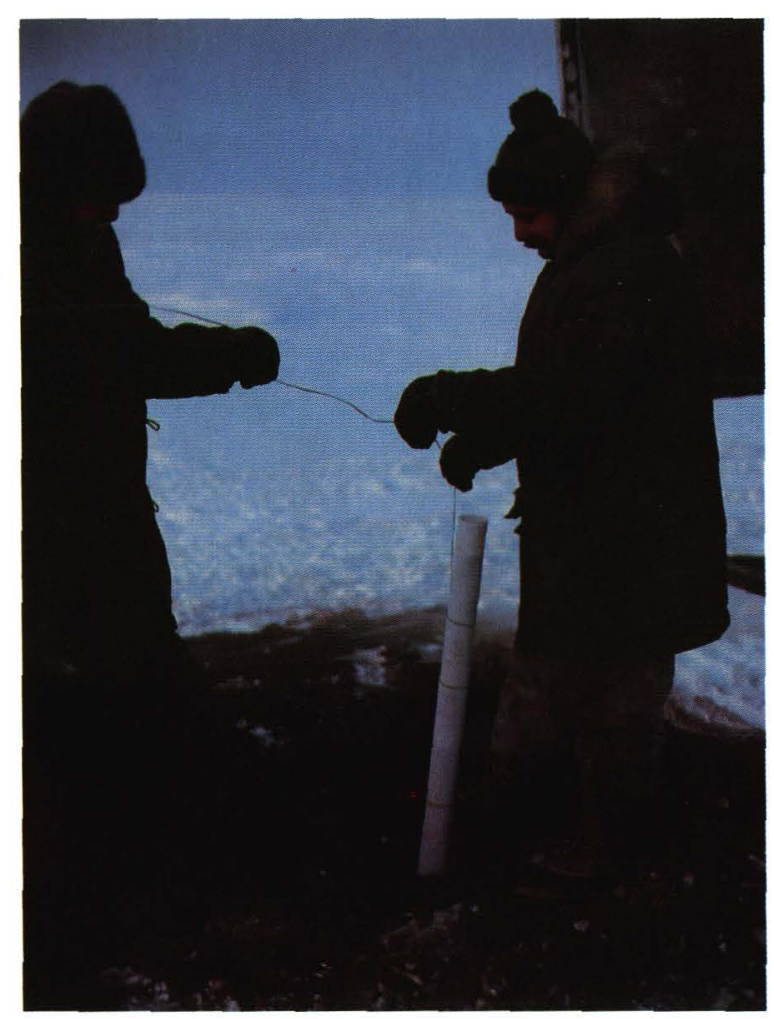

Explosives are placed into drill holes...

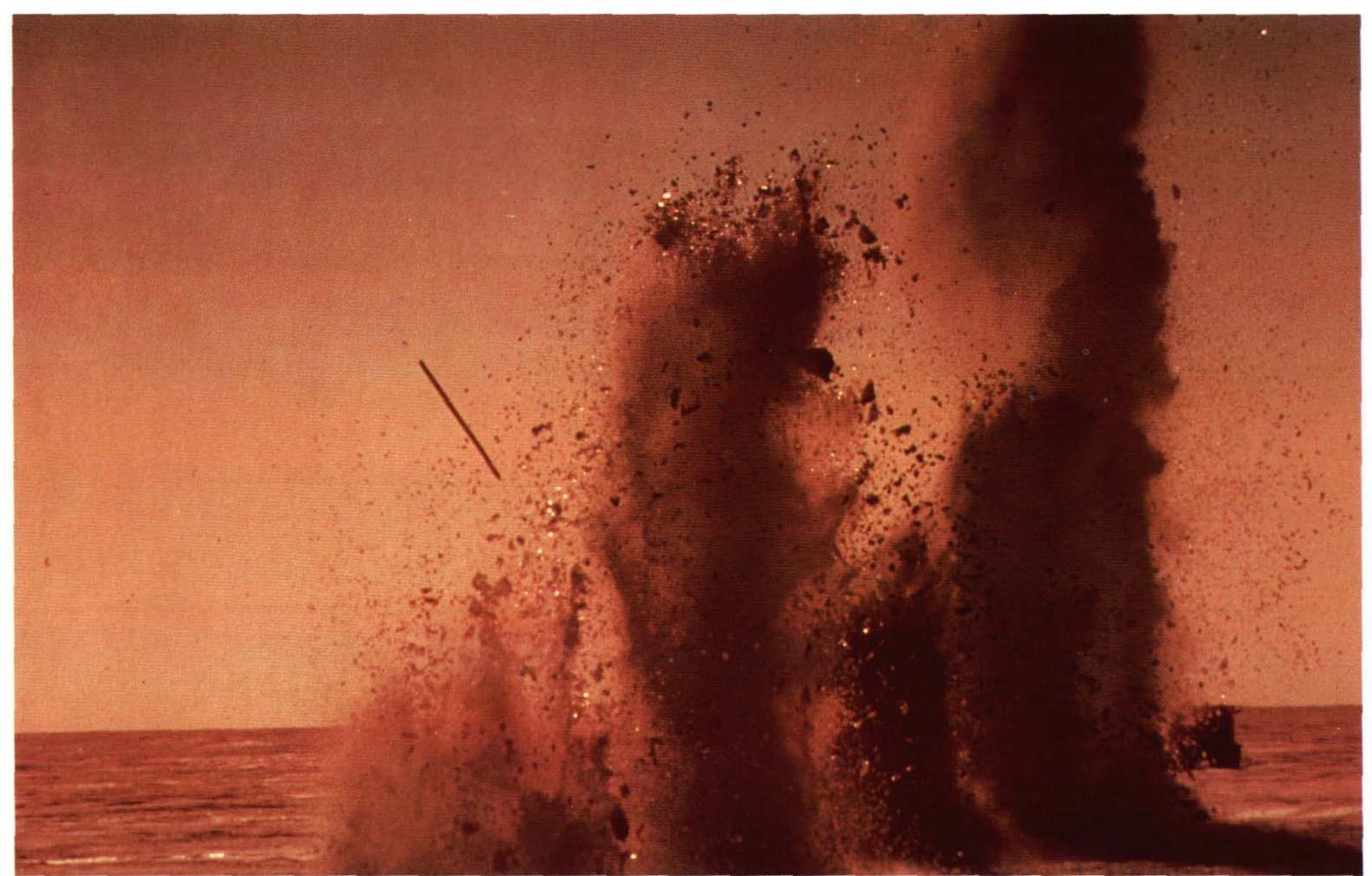

...then detonated in sequence. The sonic shock waves from the explosion travel through the subsurface and are reflected back to the surface. Photographs by John Schindler.

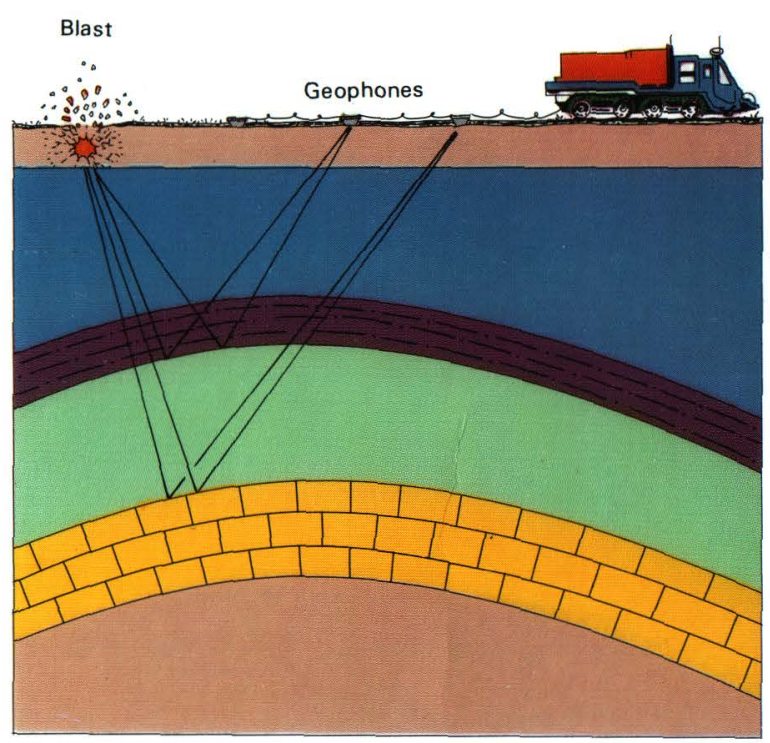

Cartoon cross section of a seismic survey. Sensitive "geophones" receive the reflected sonic shock waves and transmit data to the recording machines. 
The density and lithology of the subsurface rocks affect the velocity of the seismic shock waves and must be considered when correlating the seismic records with the drilled-well data. In general, these shock waves travel faster in dense rock. Velocities in homogenous rock layers generally increase with depth because of increasing compaction of the sediment. For example, in the Colville Group, the Nanushuk Group, and the Torok Formation, the average shock-wave velocity regularly increases from 8,000 feet per second at a subsurface depth of 1,000 feet to about 13,000 feet per second at a depth of 8,000 feet. Layers of rock with large velocity differences will cause a strong echo, which, in turn, will produce a strong signal on the seismic record. For example, the low-velocity pebble shale unit and the relatively high velocity Sag River sandstone and Shublik Formation produce strongly reflecting events, many of which can be traced over large distances in the NPRA.
Seismic-reflection profile showing rock structures nearly 5 miles into the Earth. This profile transected the Inigok well. Different reflection in the seismic record are correlated with rock layers from the well. The inset is a log of the shock-wave velocity for the different rock layers penetrated by the well.

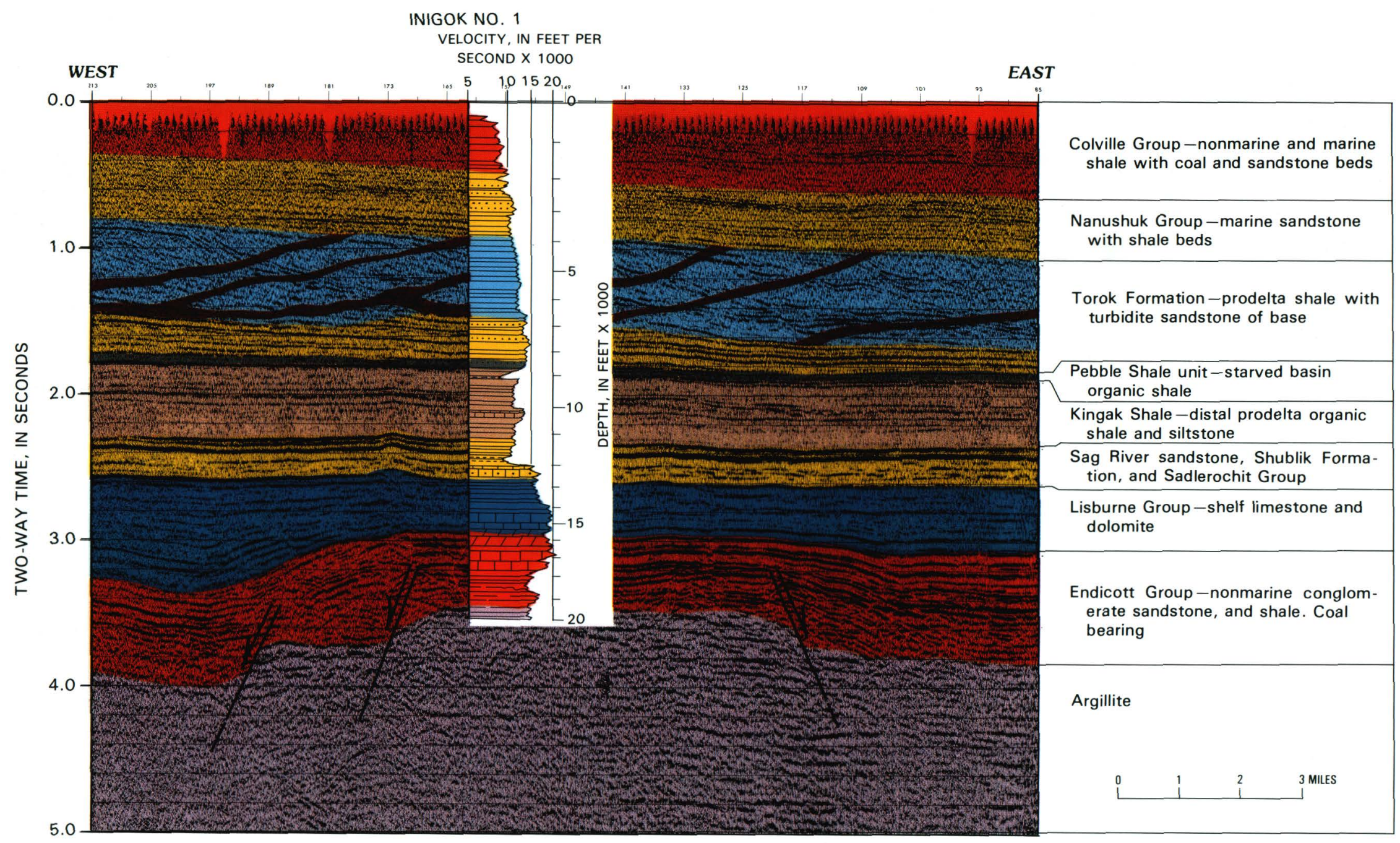


The seismic surveys were made along a series of straight lines that intersected at approximately right angles, forming a grid. Each seismic crew was supported by a train-a series of tracked vehicles on which were mounted the seismic recording equipment, drills, hole-loading equipment, and so on. The train also had a series of trailers mounted on sleds, which contained kitchen, mess hall, bathroom, sleeping facilities, supplies, and an office in which the field records were inspected and crew records were maintained. The crews operated about 5 to 6 months out of each year, from December until late April or early May, and were off the tundra before spring thaw in mid-May.

During the 10-year period of the Pet-4 program the U.S. Navy acquired about 3,300 line-miles of seismic-reflection data; and from 1974 to 1982 , the Navy and the USGS together acquired about 13,200 line-miles of data. The total 16,500 miles of seismic information and the resulting interpretations have been released to the public, have enlarged the exploration data base, and have contributed greatly to our general knowledge of northern Alaska.

Laying cable with attached geophones. Photograph by Jeep Johnson.
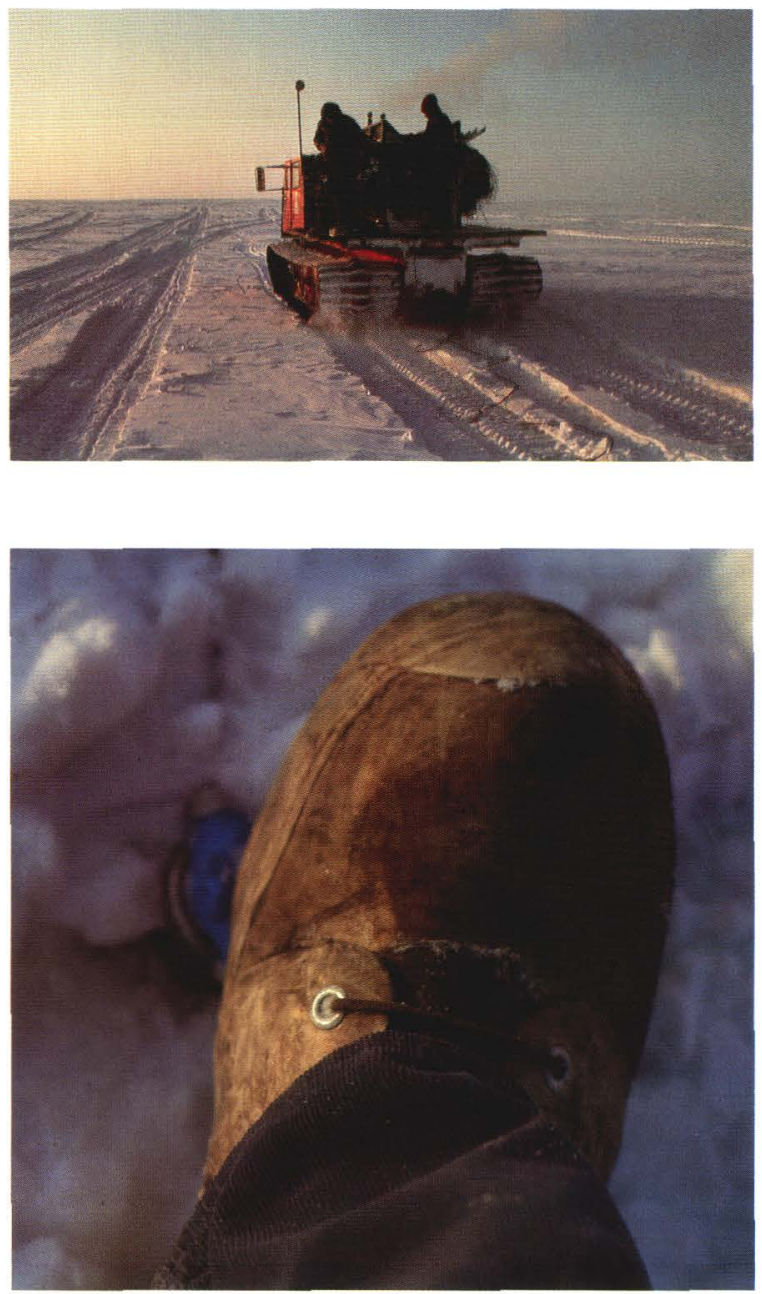

Securing geophones into the snow. Photograph by Jeep Johnson.

Nearly 15,000 miles of seismic data was collected from 1974 to 1982 


\section{Exploratory wells}

The modern exploratory well is the ultimate device for gathering detailed information about subsurface rock layers. Its main purpose, of course, is to discover oil and gas; but, in addition, factual information gathered on the deeply buried rocks is extremely valuable, and analysis of such information may suggest future prospects.

The main components of a drill rig are the mast, engines, drawworks, drill pipe, and mud system. Within the mud system, specially formulated drilling mud is continuously pumped down the interior of the drill pipe; the mud leaves the bit in the form of a jet and returns to the surface. A properly controlled mud system is of critical importance; it is designed to cool and lubricate the drill bit, support the sides of the hole, keep the well under control, reduce friction on the drill string, and remove rock particles. These rock particles, known as "cuttings," range from sand to fingernail size and are sampled periodically at the surface during drilling. Automated instruments continuously monitor the mud system for evidence of oil and gas shows.

Drill rig at the Inigok No. 1 test well. This well was the second deepest drilled in the Reserve. Photograph by Jeep Johnson.

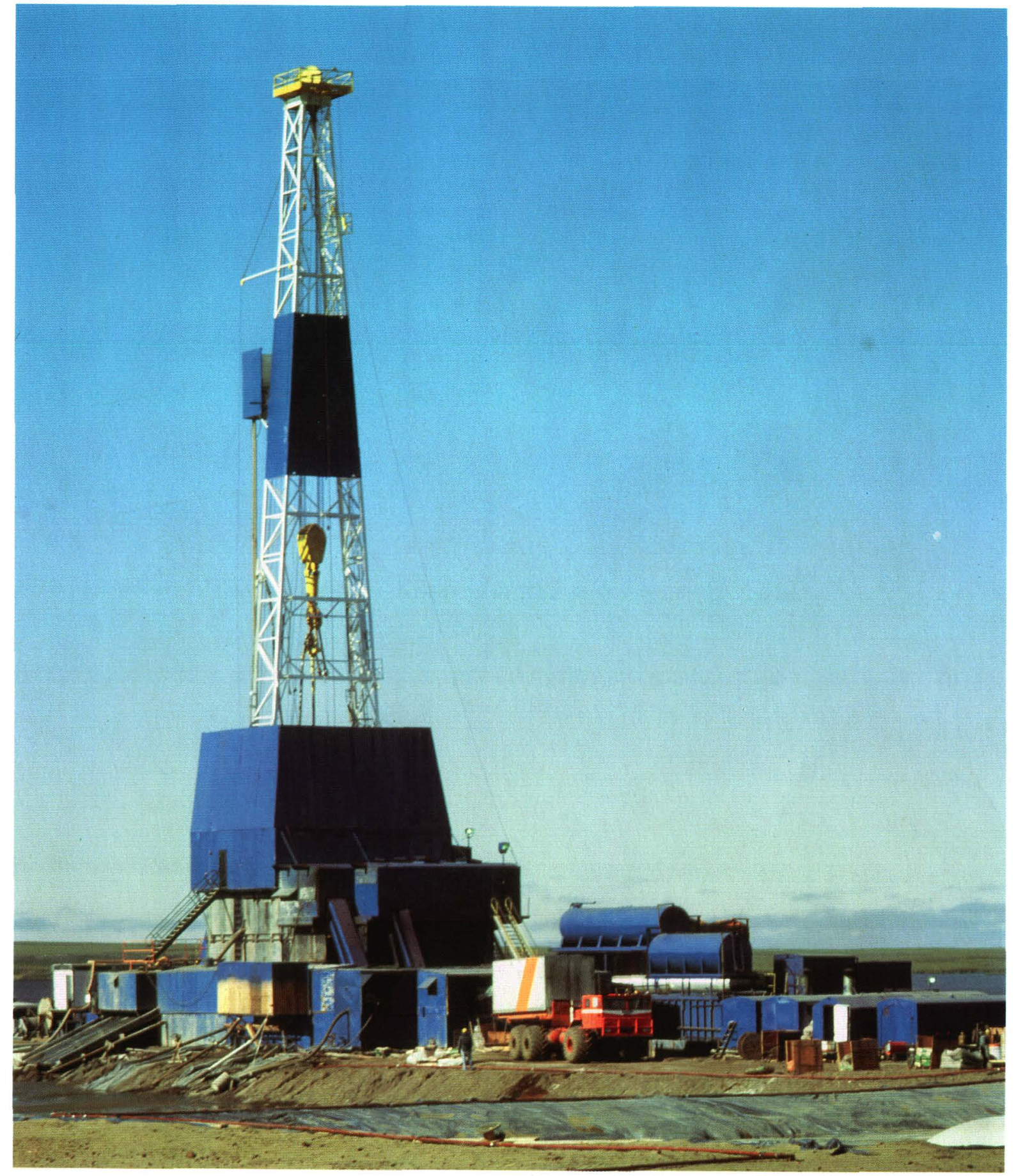


When significant shows of oil or gas are found, or whenever special rock layers are discovered, drilling may be stopped, and a core of rock taken, usually as a 10- to 30-foot-long section. Rock cores provide a large enough sample to measure two important reservoir properties-porosity and permeability. Cores also are used for geochemical analyses and commonly reveal sedimentary structures that provide important information for unraveling the ancient depositional history.
Before the borehole is cased, the well is surveyed with wireline logging devices that are encased in long metal tubes and lowered into the well. These devices measure the electrical, radioactive, and acoustic properties of the rocks to determine rock types, porosity, and fluid content. The logs of these measurements are then correlated and compared with lithologic data from the cuttings and core samples, and with seismic data, and are analyzed to determine the productive potential of oil and gas horizons.

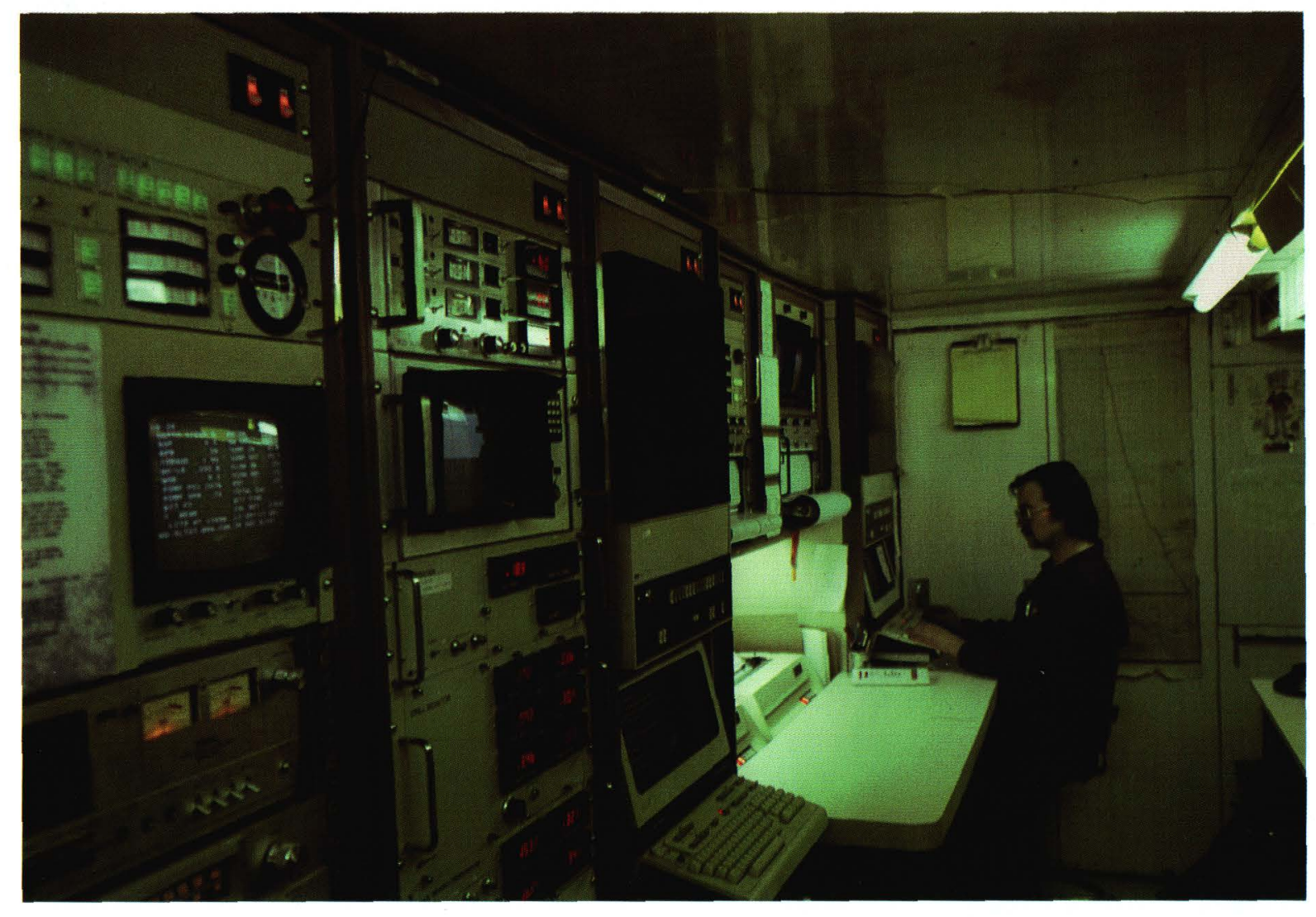

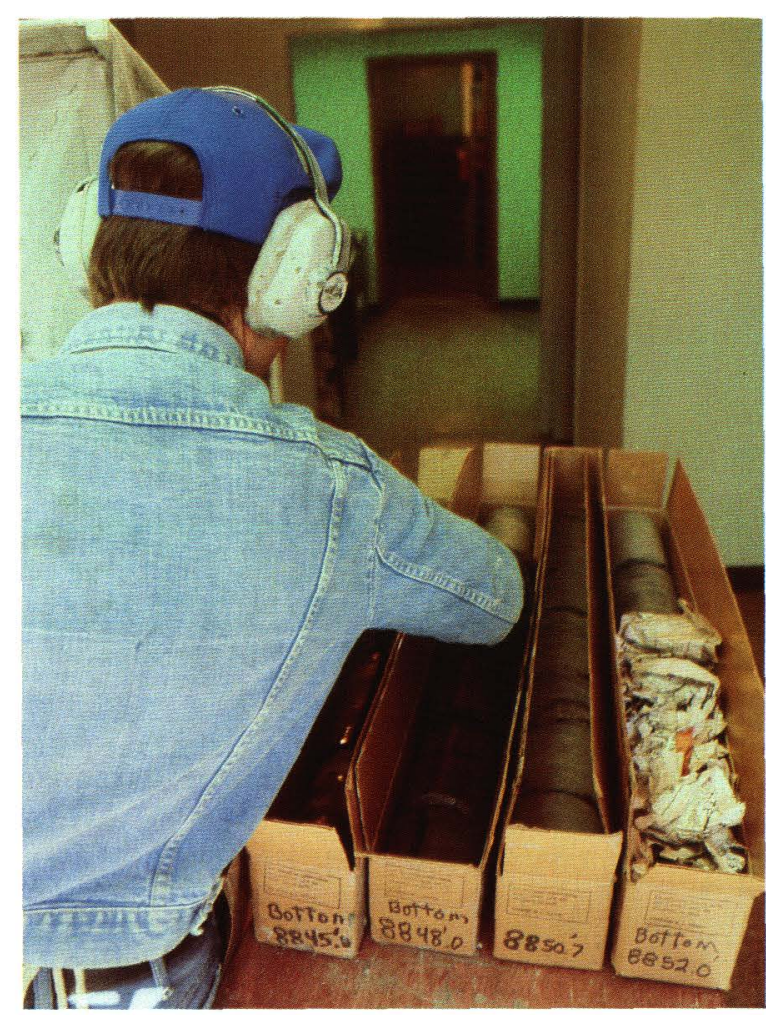

Geologist examining fresh core samples. If a petroleum-rich layer is detected, a core of the rock is generally taken. Study of a core is the best way the geologist can determine the sedimentary textures. Photograph by Jeep Johnson. 


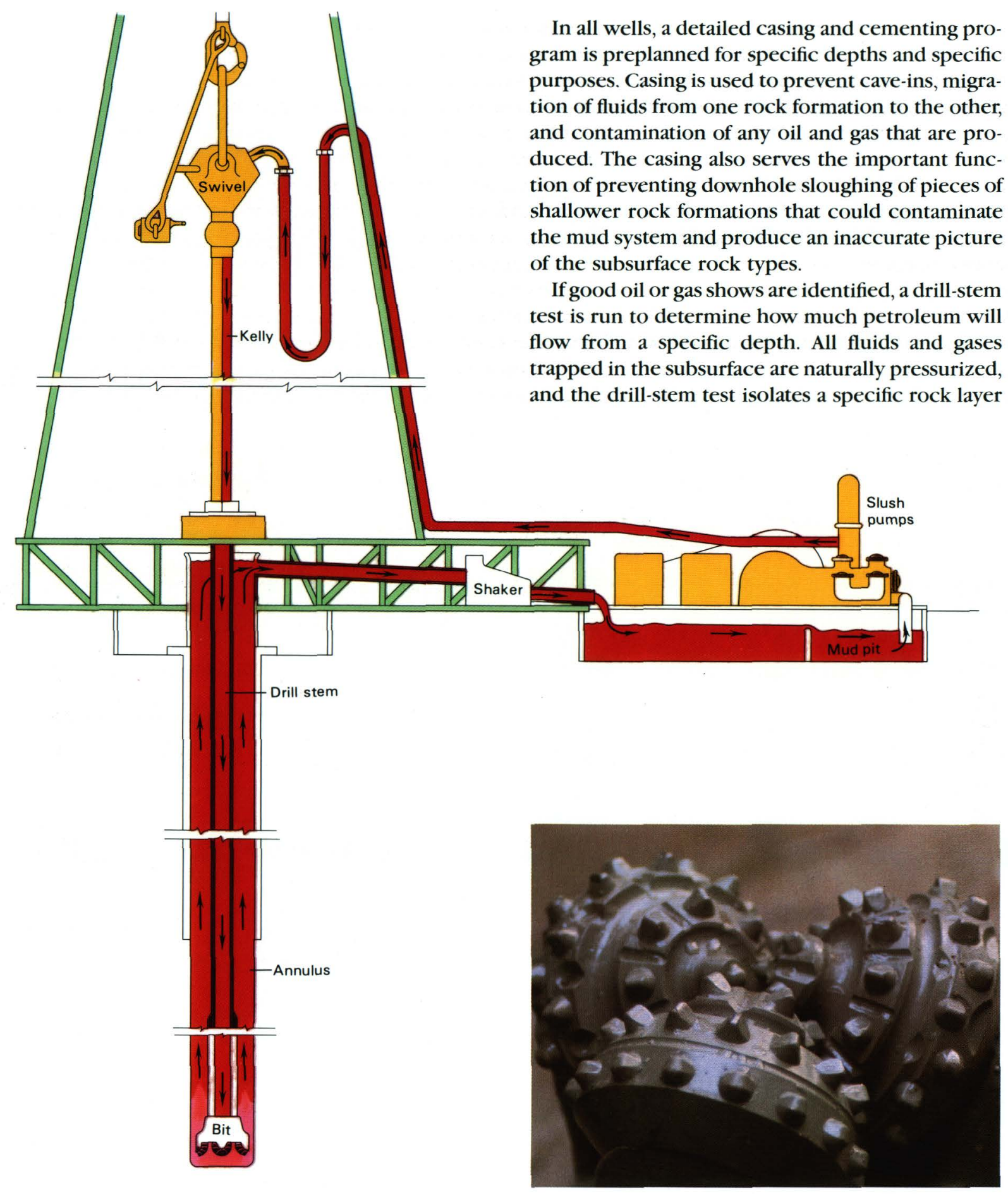

and measures the flow rate and pressure of these fluids and gases as they are released into the drill pipe and up to the surface. These tests help locate the potential petroleum-bearing layers.

The cost of drilling exploratory (wildcat) wells in the Arctic is $\mathbf{5}$ to $\mathbf{1 0}$ times greater than in the "Lower 48"; a single test well may cost more than $\$ 100$ million. The anticipated return must be considerably greater to attract investment capital. Thus, discovered deposits must be much larger in the Arctic than elsewhere to warrant development. An oil reserve of a few tens of millions or even a few hundreds of millions of barrels may not be developable profitably in the Arctic.

Diagram of a mud system. Mud is an essential component used in drilling wells. For the exploratory wells in the NPRA, automated analysers continuously monitored the mud for the presence of oil and gas.

Soft-rock drill bit. The type of drill bit used depends on the type of rocks being drilled. For rocks of the Brookian and part of the Ellesmerian sequences, soft-rock drills without embedded industrial diamonds were generally used. Photograph by John Schindler. 


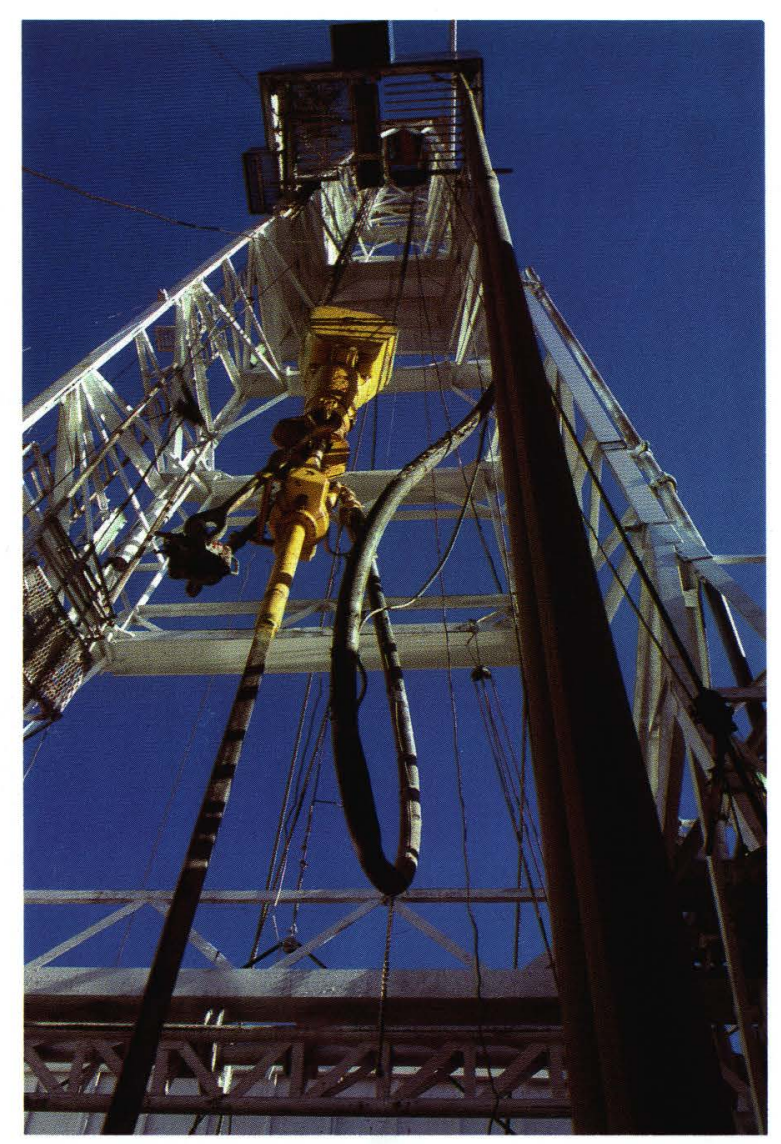

Inigok drill mast shows the mud hose (center), drill pipes (right), and the swivel (yellow) - a type of universal joint that allows the drill string to turn while mud is passing through it. Photograph by Jeep Johnson.

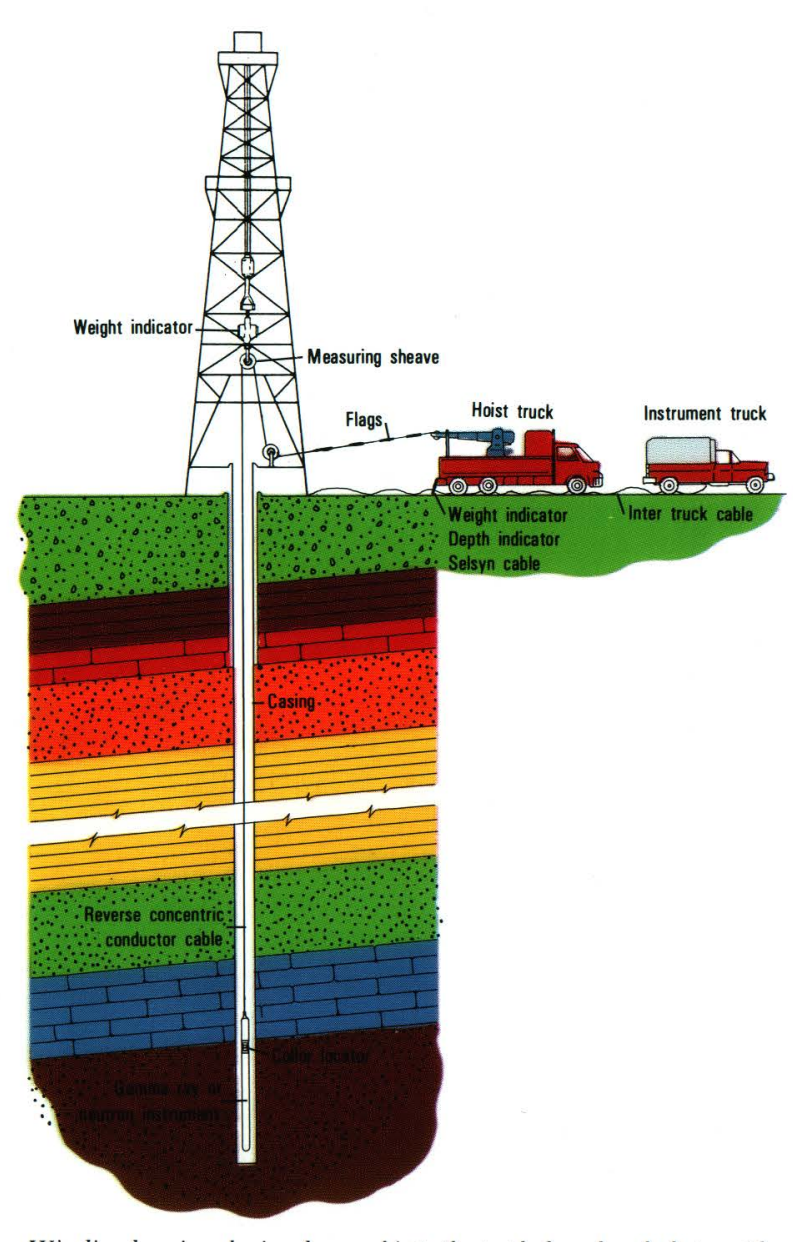

Wireline logging devices lowered into the test hole or borehole provide additional data for determining the porosity, fluid types, rock types, grain sizes, and seismic velocities of the rocks in the subsurface.

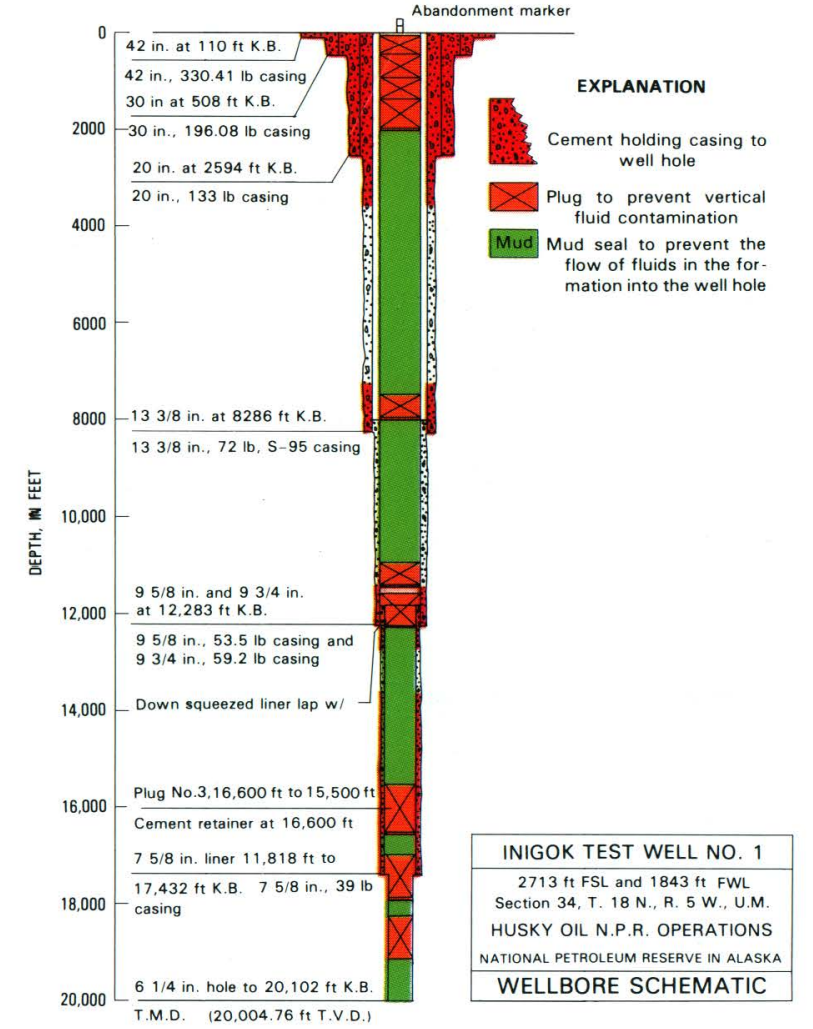

Detailed casing and cementing program from an officia! engineering report of the abandoned Inigok test well. The casing pipe is cemented to the sides of the borehole. The pipe is also suspended at the top of the well in case the cement should fail to hold (modified from Husky, 1983). 


\section{Subsurface stratigraphy}

The sedimentary rocks in the NPRA subsurface constitute a 6-to 7-mile-thick wedge of sandstone, shale, and limestone-debris that was deposited on ancient flood plains and in marine basins during the past 350 million years. These rocks form the Brookian and Ellesmerian sequences; beneath them lie older basement rocks of the Franklinian sequence. South of the coastline and the subsurface Barrow arch, few exploratory wells were drilled to depths that penetrated the Franklinian rocks because of the low economic potential of these older rocks and the cost and difficulty of drilling deep test wells.

To complete the basic stratigraphic study at a wellsite, the different rock layers are distinguished by using the cores, cuttings, and wireline-log response. Paleontologists determine the rock's age by identifying the contained microscopic fossils, the remains of plants and animals. Most common are pollen, spores, foraminifers (one-celled animals), and algae. Large fossils, like seashells, are generally destroyed during drilling, and so microfossils are most commonly used. After the ages and rock types are determined, a "stratigraphic column" is drawn up for each wellsite. With this information in hand, stratigraphic relations and changes, such as thinning or thickening and lithologic variations of a certain layer, can be compared and correlated from well to well. Geologists then use the seismic records to predict the configuration and composition of the subsurface rocks between the wells.
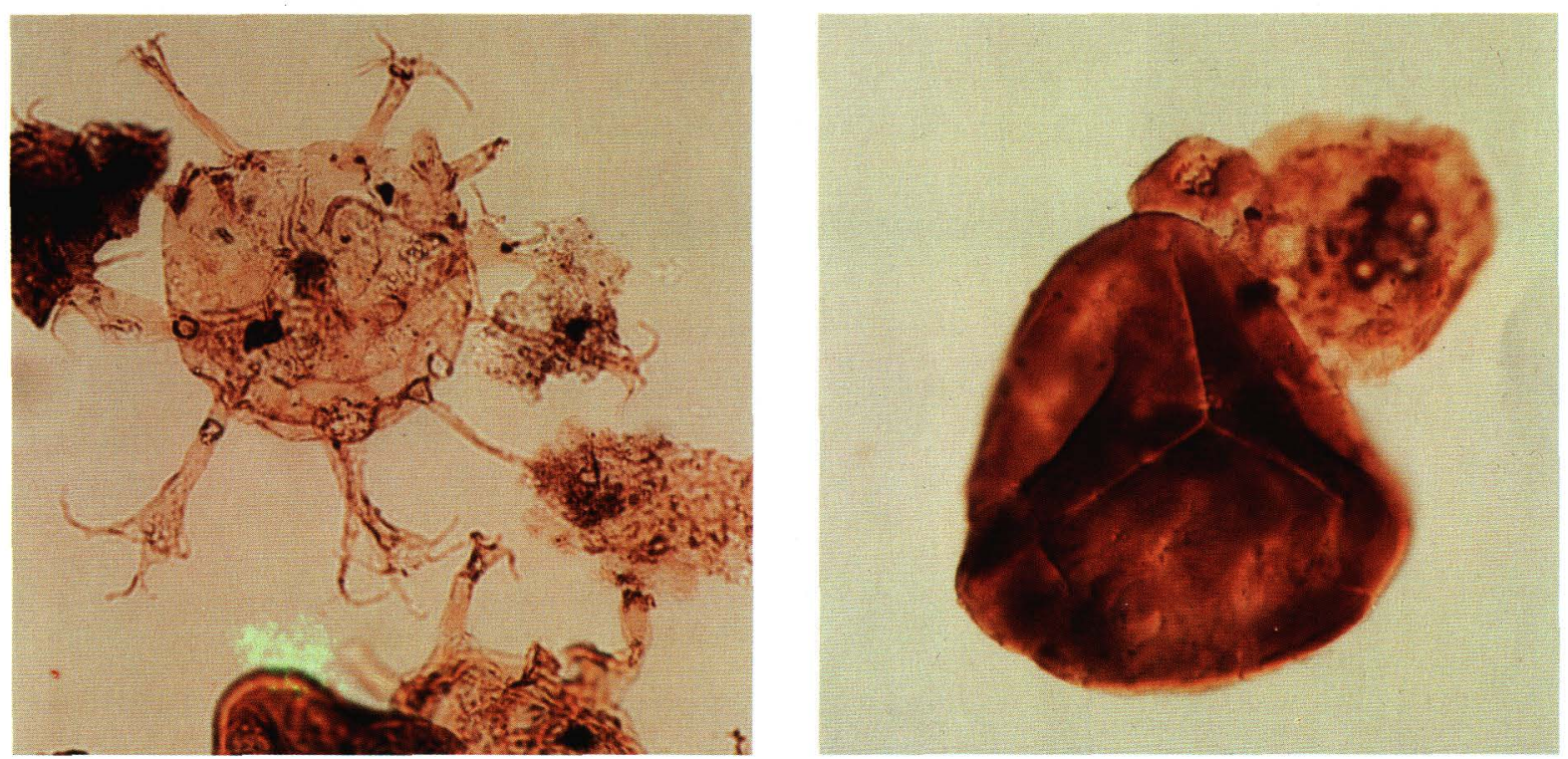

Ancient marine planktons (dinoflagellates) and plant spores from the pebble shale unit. From left to right: Oligosphaeridium complex. $\times 450$; Deltoidospora sp., $\times 500$; and Lycopodium sporites sp., $\times$ 800. These extinct forms of plant spores and planktons, preserved in the pebble shale, helped to determine that the age of the sediment is Early Cretaceous. Photograph courtesy of Roger Witmer. 


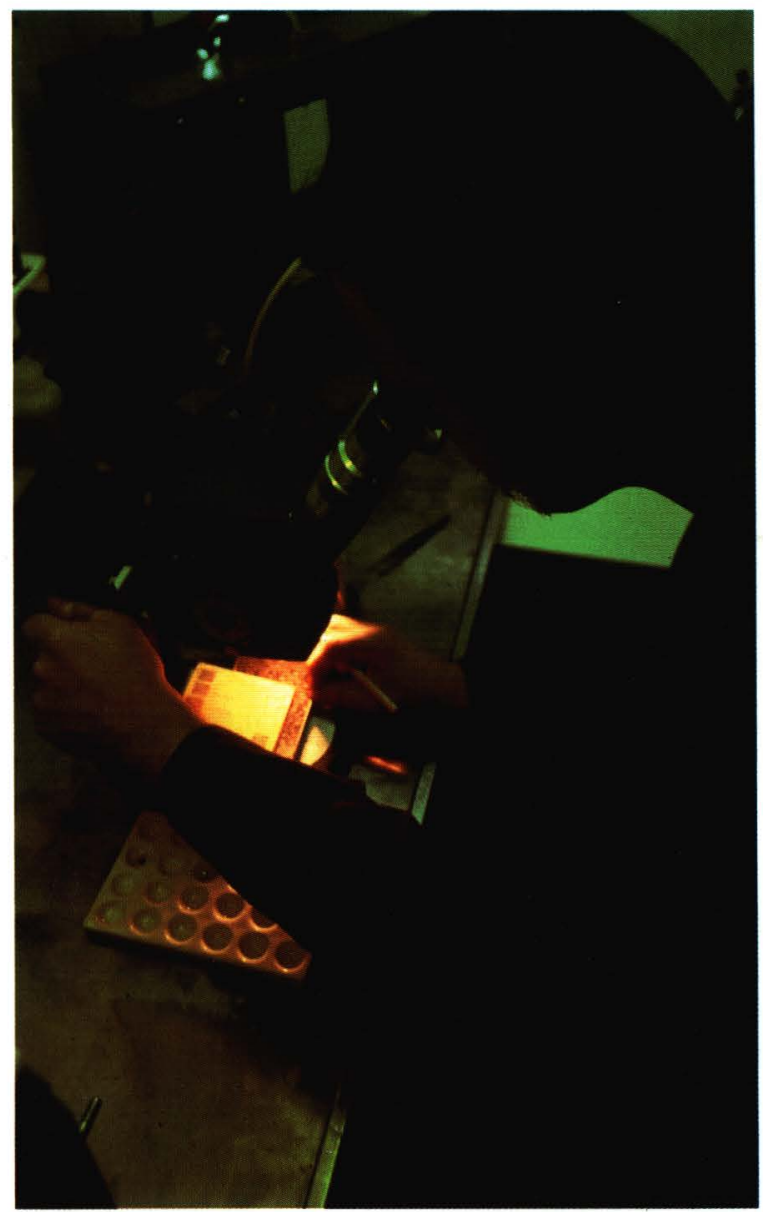

Small rock "cuttings" brought to the surface by the circulating drilling mud are periodically sampled and analysed. Photograph by Jeep Johnson.

\begin{tabular}{|c|c|c|c|c|c|}
\hline SEQ. & \multicolumn{2}{|r|}{ AGE } & UNIT & LITHOLOGY & DESCRIPTION \\
\hline \multirow{5}{*}{$\begin{array}{l}z \\
\frac{\alpha}{1} \\
\frac{\mathbf{x}}{0} \\
0 \\
\frac{0}{0}\end{array}$} & \multirow{2}{*}{ 离品 } & $\begin{array}{l}\text { QUATERNARY AND } \\
\text { TERTIARY }\end{array}$ & Gubik Formation & & Sand, silt, gravel, and clay, shallow marine and nonmarine \\
\hline & & TERTIARY & $\begin{array}{l}\text { Sagavanirktok } \\
\text { Formation }\end{array}$ & & \multirow{4}{*}{$\begin{array}{l}\text { Sediment derived from the Brooks Range terranes pro- } \\
\text { graded northerly and easterly to fill the Colville Basin. } \\
\text { When the basin was filled with four miles or more of } \\
\text { sediment the ancient delta system overtopped the } \\
\text { Barrow arch and prograded northerly onto the Beaufort } \\
\text { shelf. }\end{array}$} \\
\hline & \multirow{9}{*}{$\begin{array}{l}\text { U } \\
\text { O } \\
\text { On } \\
\text { W } \\
\text { L }\end{array}$} & \multirow{3}{*}{ 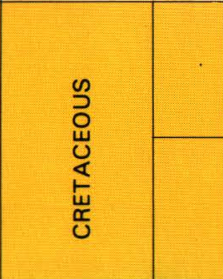 } & \multirow[b]{2}{*}{ Nanushuk Group } & \multirow{3}{*}{\begin{tabular}{l}
$\because$ \\
\hdashline$\because$ \\
\hdashline \\
\\
\hdashline \\
0
\end{tabular}} & \\
\hline & & & & & \\
\hline & & & $\begin{array}{l}\sum_{\text {Fortress }}^{\text {Torok }} \\
\text { Mountain Formation } \\
\text { Formation }\end{array}$ & & \\
\hline \multirow{10}{*}{ 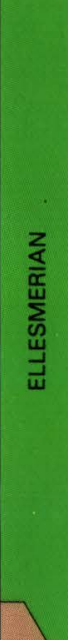 } & & \multirow[b]{3}{*}{ JURASSIC } & Pebble Shale unit & & \multirow{10}{*}{$\begin{array}{l}\text { Sediment derived from a northerly source. Generally the } \\
\text { sediments coarsen and the layers thin from bottom to } \\
\text { top. } \\
\text { Basal part of the Endicott Group consists of non-marine } \\
\text { coal-bearing sandstones and shales deposited in down- } \\
\text { faulted basins on the Arctic platform. }\end{array}$} \\
\hline & & & & & \\
\hline & & & Kingak Snale & & \\
\hline & & \multirow{3}{*}{ TRIASSIC } & Sag River Sandstone & & \\
\hline & & & Shublik Formation & ?. 1 & \\
\hline & & & \multirow[t]{2}{*}{ Sadlerochit Group } & - & \\
\hline & \multirow{4}{*}{ 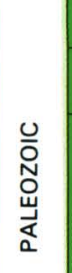 } & PERMIAN & & $\cdots$ & \\
\hline & & PENNSYLVANIAN & & 1 & \\
\hline & & \multirow{2}{*}{ MISSISSIPPIAN } & Lisburne Group & \begin{tabular}{l|l}
$\frac{1}{1}$ \\
$\frac{1}{1}$ \\
$\frac{1}{1}$
\end{tabular} & \\
\hline & & & $\begin{array}{l}\text { Endicott Group } \\
\text { (part) }\end{array}$ & & \\
\hline 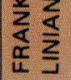 & & $\begin{array}{l}\text { PRE-MISSIS } \\
\text { SIPPIAN }\end{array}$ & Argillite & & Low-grade metamorphic rocks \\
\hline
\end{tabular}

General stratigraphic column of NPRA rocks. 


\section{Source rocks}

Field and laboratory studies indicate that naturally occurring oil and gas are the products of heated organic matter, except for biogenic gas, which is formed by bacterial action. These studies show that certain types of organic matter are necessary, that these types must occur in certain minimum concentrations, and that they must be heated to a certain threshold but not too far beyond, or the oil and gas will be destroyed or "burned up." A source rock is a body of rock from which oil and gas can be derived. Petroleum geologists can improve the chance of finding oil and gas by studying possible source rocks before an exploration program is begun. If no organic-rich source rocks are observed, then the prospects of finding oil or gas in that area are diminished. However, oil and gas can migrate great distances, and so that criterion must be used with care, and the regional geology must also be considered.

Assessment of source-rock potential requires that four major questions be answered: (1) Is there a sufficient amount of organic matter in the rocks? (2) What kind of organic matter is present? (3) Has the thermal history of the area been appropriate for generating oil and gas and subsequently appropriate for preserving it? and (4) Have oil and gas actually been generated? These four questions are answered by observations and by carrying out several types of geochemical analyses in the laboratory that evaluate the overall petroleum potential of the rocks.

Organic material must be heated to a certain degree to generate hydrocarbons. This cross section shows the depth and structural conditions under which organic material might be transformed into oil or gas (modified from Bird, 1981).
The amount of organic matter in the rocks is determined by an analysis of their organic-carbon content (OCC); organic material, which originated from either terrestrial or marine organisms, is measured in weight percent. The OCC by itself indicates the organic richness of the rocks but gives no clue as to the presence or generation of oil and gas. OCC's of 0.5 to 2.0 weight percent indicate a possibly fair source rock, and of greater than 2.0 weight percent a possibly good to excellent source rock.

The kind of organic material present is determined by studying samples under a microscope and by chemical analysis. Marine organic materials produce mostly oil, whereas terrestrial materials produce mostly gas. Thus, from knowledge of the kind of organic material present in an area, the type of petroleum most apt to be found can be predicted. This determination may be of critical importance to the economics of production and marketing. For example, there is no gas pipeline out of the North Slope and thus no way of economically transporting gas to market.

The thermal history of the basin determines whether the rock has been heated to the appropriate degree and for the right length of time-not too long and not too short-for the generation of oil and gas. The thermal history is disclosed by several methods. One type of qualitative analysis is the

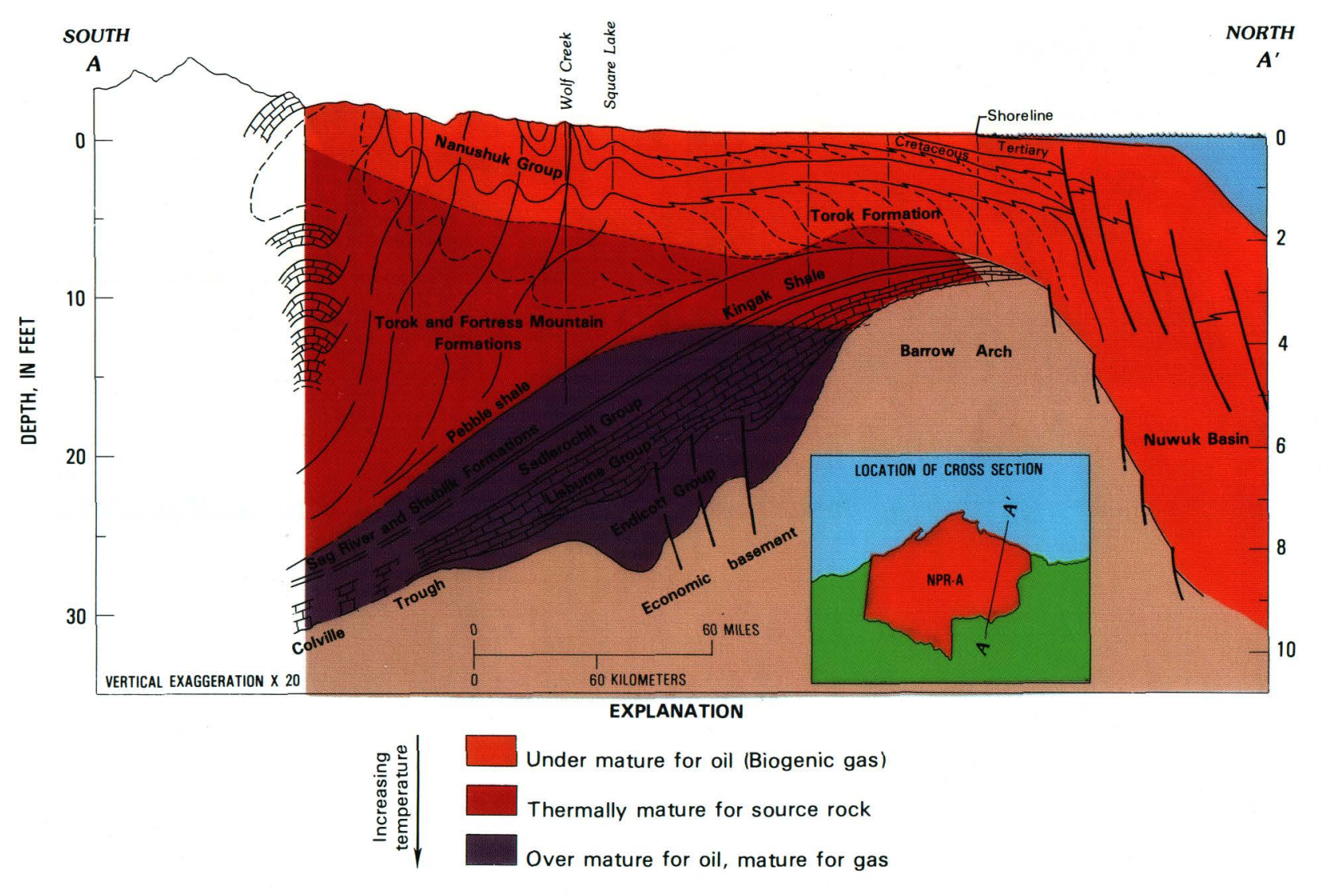

South to north cross section: Potential oil source rocks shown in red 
"thermal-alteration index," based on the progressive color change, or darkening, of specific fossil types with increasing temperature.

The most recent studies show that four marine shale units have the appropriate complement of parameters to be considered as a source for oil: the Torok Formation, the pebble shale unit, the Kingak Shale, and the Shublik Formation. These rocks are thermally immature along a relatively narrow zone parallel to the northeast coastline of the NPRA (the Barrow arch ), but as they thicken toward the south and become more deeply buried, the rocks become more mature and have produced oil and gas. The richest but thinnest source rock, on the basis of all these analyses, is the 120-million-year-old pebble shale unit.

Whether oil and gas have actually been generated can be answered by observation. During drilling, many oil and gas shows were penetrated in each of these formations and related reservoir rocks. These shows lead to the conclusion that oil and gas were generated. However, they may not be present in sufficient amounts to form economic deposits for some reason, such as the absence of traps or migration of the oil and gas to other areas.

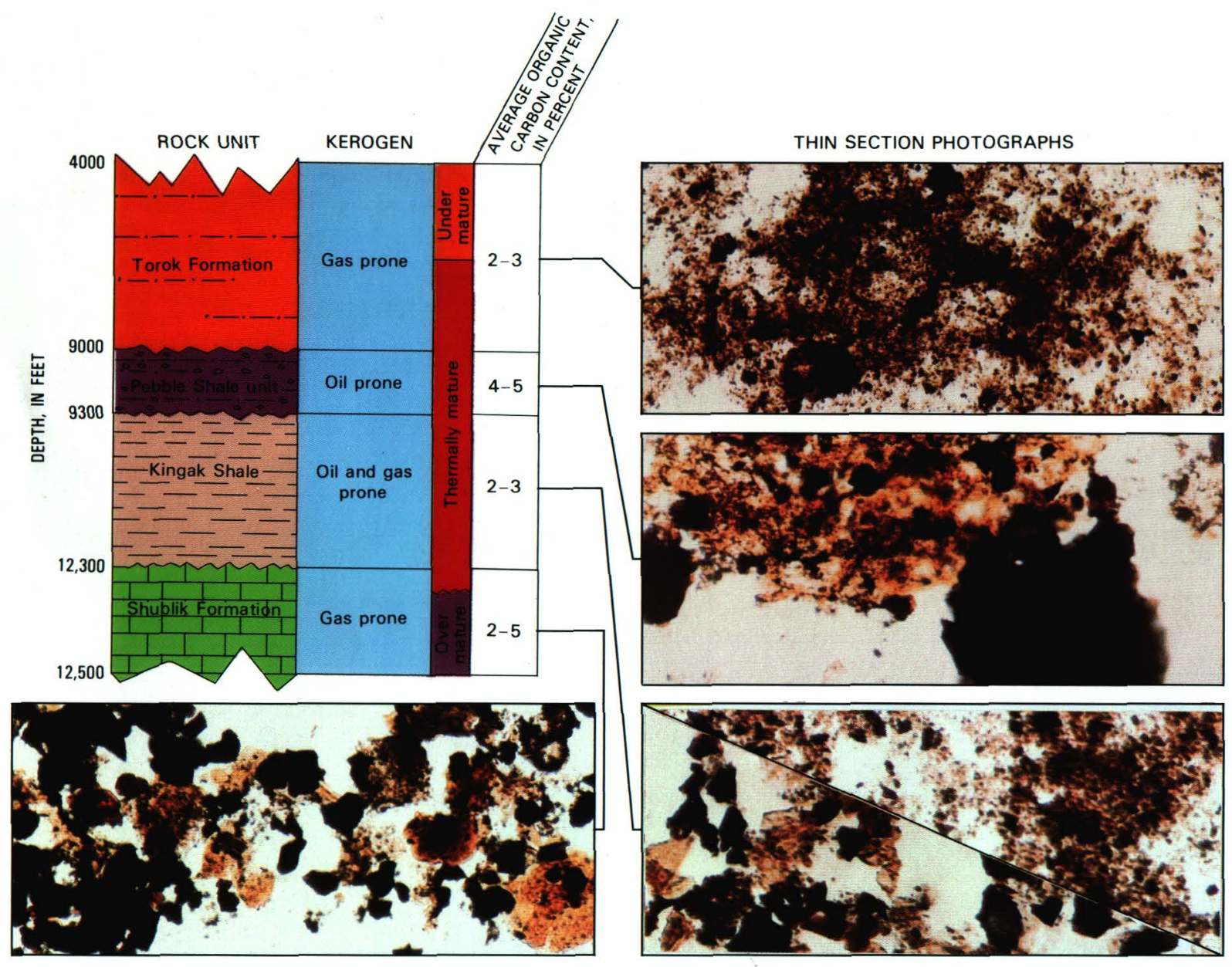

Photomicrographs of thin sections of the Torok Formation, the pebble shale unit, the Kingak Shale, and the Shublik Formations - all possible source rocks in the NPRA. Organic material shows up as black splotches. 


\section{Reservoir rocks}

Any porous rock layer with interconnecting open spaces or holes is a potential petroleum reservoir. The proportion of open space is called porosity, measured in volume percent. Thus, 25 percent porosity means tha one-fourth of the rock consists of pore space. The interconnectedness of pore spaces, which provide the paths for circulating fluids, is referred to as permeability, the ability to transmit fluids. The degree of porosity and permeability is the result of the depositional environment, the history of burial and consolidation, and secondary effects, such as fracturing and etching.

Examples of sediment that may form good reservoirs are well-sorted beach or channel sand and limy sand derived from broken fragments of coral reefs. Hard and brittle rocks may become porous by fracturing or etching by circulating fluids, so that open spaces are created.

Predicting which rock layers may be good reservoirs is one of the most important factors in petroleum exploration. Petroleum geologists spend considerable time and effort studying modern sedimentary or depositional environments as a key to understanding ancient environments as represented by the rock sequence. Models and criteria are organized to identify paleoenvironments and thus to predict the reservoir properties of the rocks that have been formed. The position and configuration of ancient sedimentary-transport systems are also important in prediction. Coarse, well-sorted sandy and cobbly sediment derived from an ancient river system or shoreline may grade laterally into finer sand from an offshore bar, through muddy marine-shelf deposits, eventually to an organic-rich deep-water clay. As the shorelines and rivers move and change, different kinds of sediment are deposited, one on the other, to form a sequence with a complex sedimentary history. A specialist, a sedimentologist, may spend an entire career studying these sequences to predict where good reservoir rocks may be found.

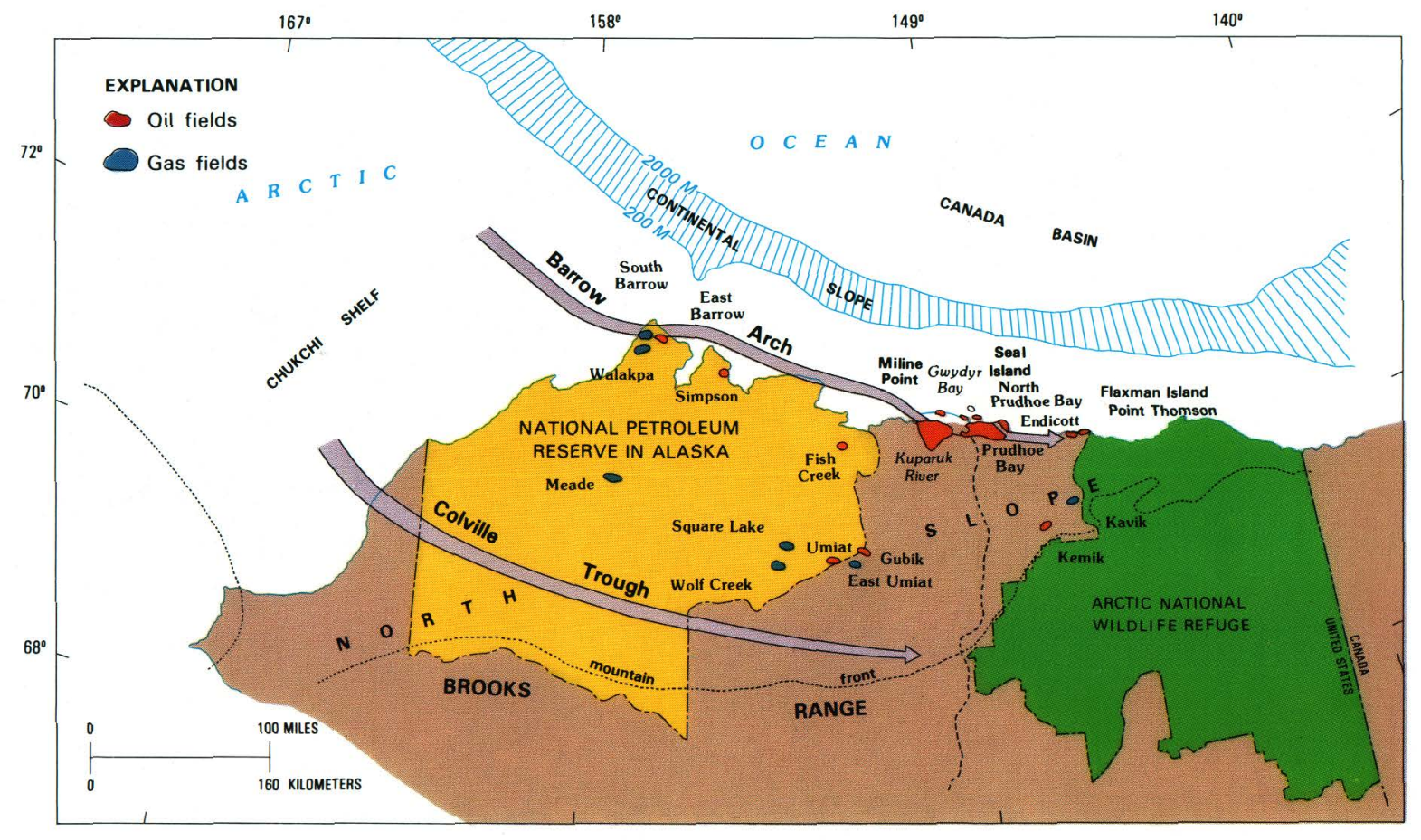

Locations of known petroleum reservoirs in the NPRA (modified from Bird, 1981).

\section{STRATIGRAPHIC TRAP}

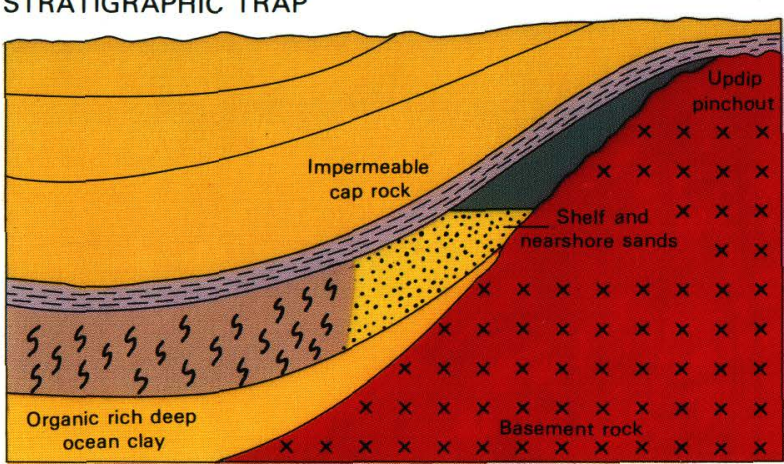

STRUCTURAL TRAP

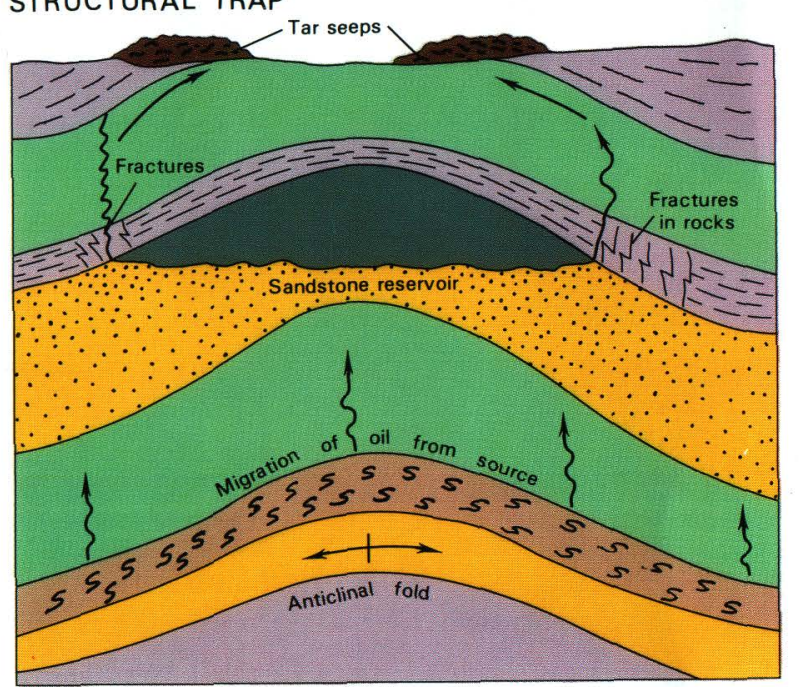



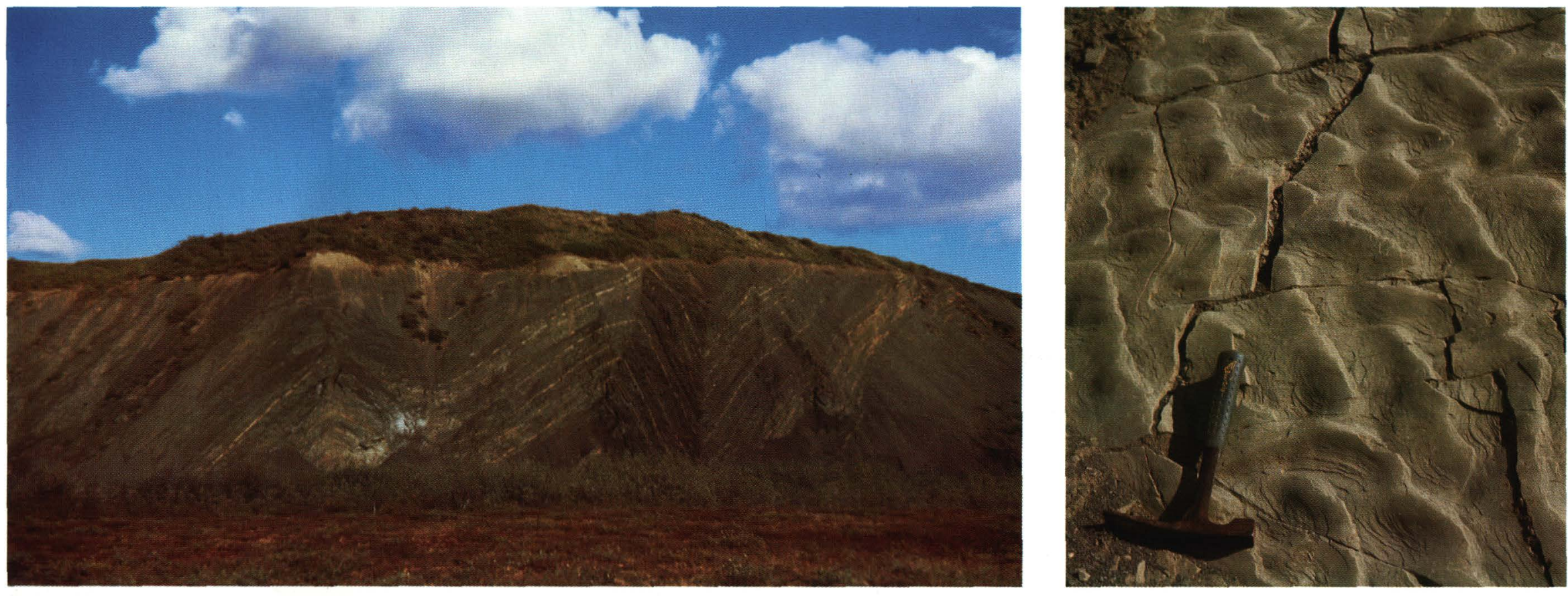

Large chevron folds in the Torok Formation exposed along a riverbank in the foothills. These folds are associated with a much larger scale folding event that included broad anticlines and synclines several miles across. The large-scale anticlines were targets for many of the exploratory wells. Photograph by Irvin Tailleur.

To form an oil or gas deposit, the reservoir rock must be situated in some form of trap, commonly a fold or anticline. Oil and (or) gas migrate into this structure and are trapped, provided the reservoir is sealed by enclosing rocks or structures. The sealing rock may be an impermeable clay or shale, or a fault may seal off the deposit. Because most reservoir rocks are naturally water saturated, the oil and gas rise or float to the top of the trapped accumulation to form the classic configuration of a layer of water, then of oil, and finally a gas cap. The determination of these layers, their extent and location, are important in estimating the size of the deposit and its

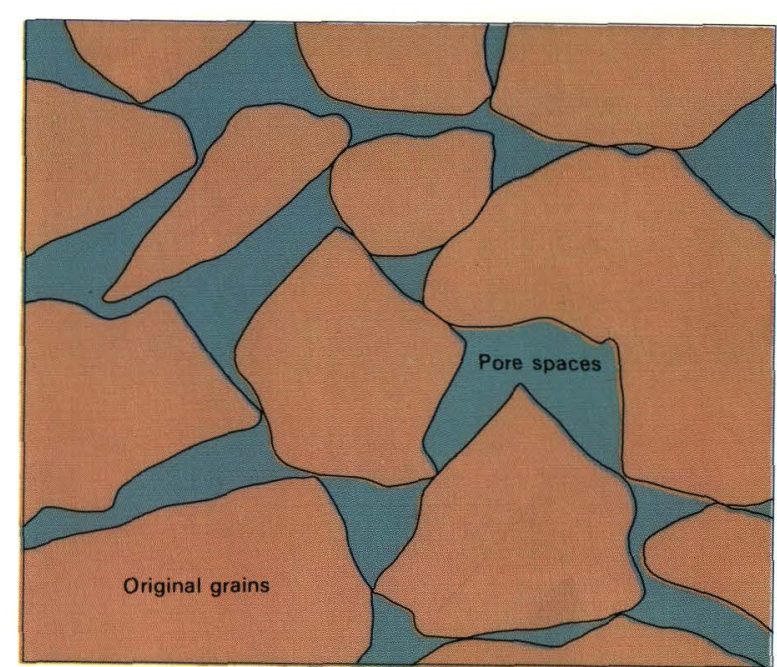

The uneven packing of sedimentary grains forms natural pore spaces. Migrating oil may fill these spaces and, if sealed above by an impermeable layer of rock, may remain in place for millions of years.
Preserved current ripples in the Fortress Mountain Formation that formed on an ancient ocean floor near the newly uplifted Brooks Range. Current ripples reveal the flow direction of ancient oceanbottom currents, which can indicate the direction to possible reservoirs. Photograph by Irvin Tailleur.

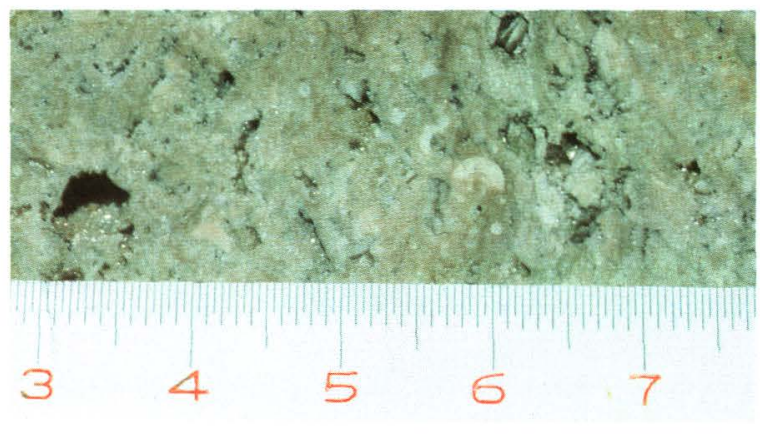

Dolomite sample from the Lisburne Group reveals tar trapped in pore spaces. The pore spaces, or "vugs," were once fossilized fragments of seashells that have since been dissolved, creating a secondary porosity. Photograph by William W. Chamberlain. potential production. 
Within the NPRA, good reservoir rocks are relatively scarce in comparison with the adjacent Prudhoe Bay area. However, reservoir rocks containing small or residual accumulations have been found in rocks ranging in age from Mississippian to Cretaceous. Significant oil accumulations have been found within the Nanushuk Group of Cretaceous age at Umiat, Simpson, Fish Creek, and Umiat, and gas accumulations at Umiat, Gubik, Meade, Simpson, Wolf Creek, and East Umiat. The Barrow gas deposits are in reservoirs in the Kingak Shale of Jurassic age. At the W. T. Foran and J. W. Dalton test wells along the Arctic coast, residual hydrocarbons were found in rocks of Mississippian and Permian age, coeval with the reservoir rocks in the Prudhoe Bay area.

\begin{tabular}{|c|c|c|}
\hline Well Name & Rock Formation & $\begin{array}{c}\text { Maximum flow rate during } \\
\text { drill stem test }\end{array}$ \\
\hline Fish Creak & Nanushuk & Small oil recovery \\
\hline Gubik & Colville & Up to $8 \mathrm{MMCF} /$ day \\
\hline Meade No. 1 & Nanushuk & $1.1 \mathrm{MMCF} / \mathrm{day}$ \\
\hline N. lnigak No: & Torok & $.08 \mathrm{MMCF} /$ day \\
\hline Lisburne & Lisburne & $.7 \mathrm{MMCF} / \mathrm{day}$ \\
\hline Seabee No. 1 & Nanushuk & 6.7 MMCF/day \\
\hline Simpson No. 1 & Nanushuk & 3.0 MMCF/day \\
\hline Simpson No. 26 & Nanushuk & Up to $120 \mathrm{bbls} /$ day \\
\hline Umiat No. 5 & Nanushuk & Up to $450 \mathrm{bbls} / \mathrm{day}$ \\
\hline Umiat No. 8 & Nanushuk & 6.0 MMCF/day \\
\hline Walakpa No. 1 & Pebble Shale unit & 2.3 MMCF/day \\
\hline Wolf Creek No. 1 & Nanushuk & 1.1 MMCF/day \\
\hline Barrow No. 19, No. 14 & Kingak & $7 \mathrm{MMCF} /$ day (production rate) \\
\hline \multicolumn{3}{|c|}{$\begin{array}{l}\text { The most productive oil well in Prudhoe Bay is listed as producing } 16,000 \text { bbls/day } \\
\text { however most wellis produce between } 3,000 \text { and } 5,000 \text { bbls/day. }\end{array}$} \\
\hline \multicolumn{3}{|c|}{$\begin{array}{l}\text { MMCF/day=million cubic feet per day. } \\
\text { bbls/day=barrels per day. }\end{array}$} \\
\hline
\end{tabular}

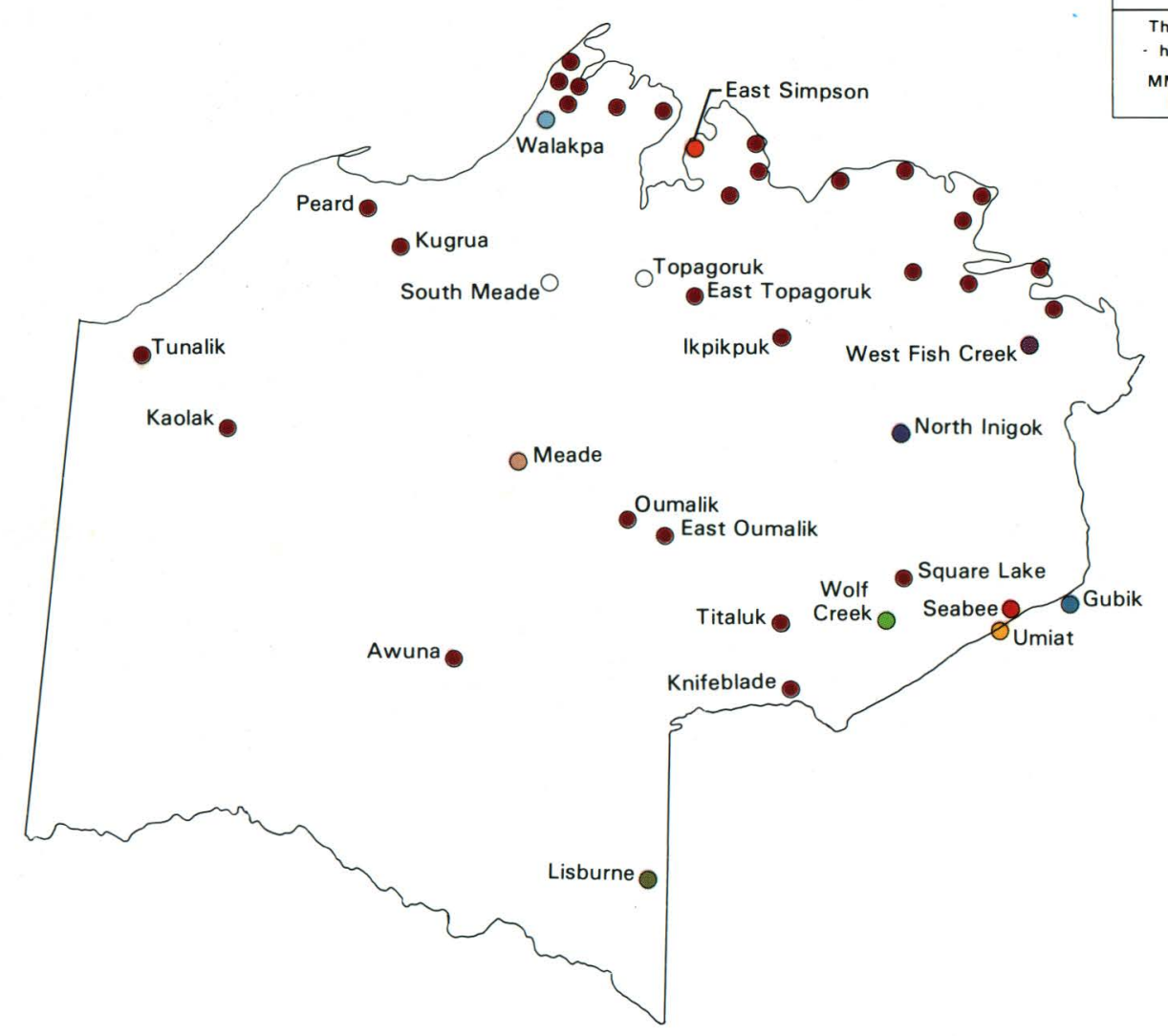

Drill-stem tests were made at several wells in the NPRA. If oil and gas shows were detected, a test was made at a specific depth to measure the possible flow rate and pressure of the oil or gas. These tests verify the presence of oil or gas reservoirs but do not determine the total amount of petroleum that might be trapped. Map shows locations of 28 wells drilled during the most recent program. 


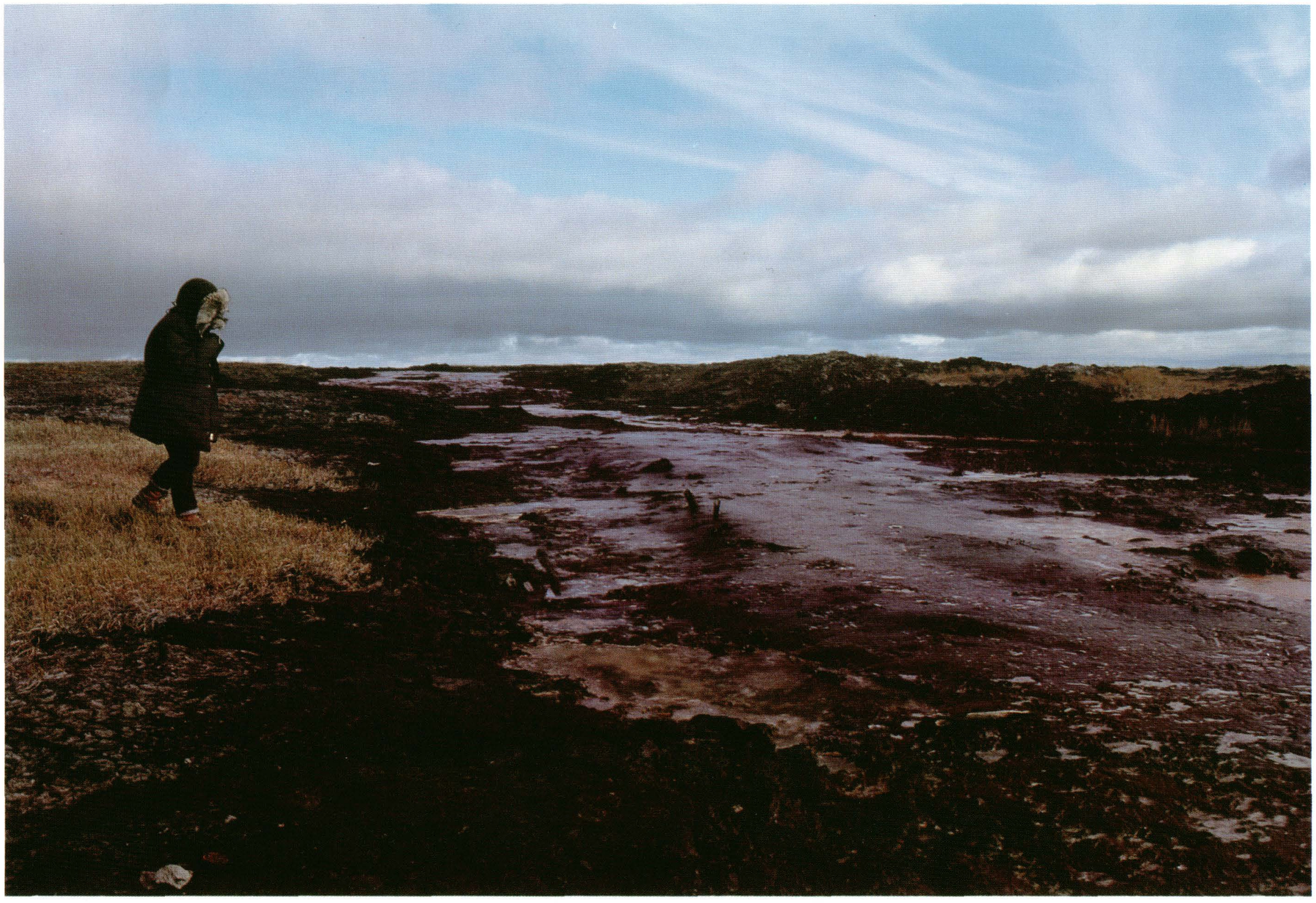

Crude-oil seepages near Cape Simpson. Some of the first explorer: described these seeps, and the Natives used the tar as fuel. Photograph by George Gryc. 

How were oil and gas
resources estimated?

Example of a play-analysis data form, annotated to show the two fundamental questions asked in any petroleum-resource assessment.
Although estimates of oil and gas resources were regarded as probably the most important economic contribution to studies of the NPRA, the Naval Petroleum Reserves Production Act of 1976 (Public Law 94-258) required much more. To satisfy all the requirements of the act, an interactive com puter-based economic model was constructed. Estimates of the amounts of yet-to-be-discovered oi and gas in the NPRA were basic to this economic model. The model simulated the economic con sequences of various development plans to satisfy the act, which specifically required a study to deter- mine the best overall procedures for the development, production, transportation, and distribution of any petroleum resources in the Reserve, and the economic and environmental consequences of the various procedures. The following paragraphs briefly describe the method of arriving at the estimates that were provided to the economic model. The reader interested in more details should consult the report by the U.S. Department of the Interior, Office of Minerals Policy and Research Analysis (1979).

\section{OIL AND GAS APPRAISAL DATA FORM}

EVALUATOR: U.S. Geological Survey PLAY NAME: DATE EVALUATED: REVISED:

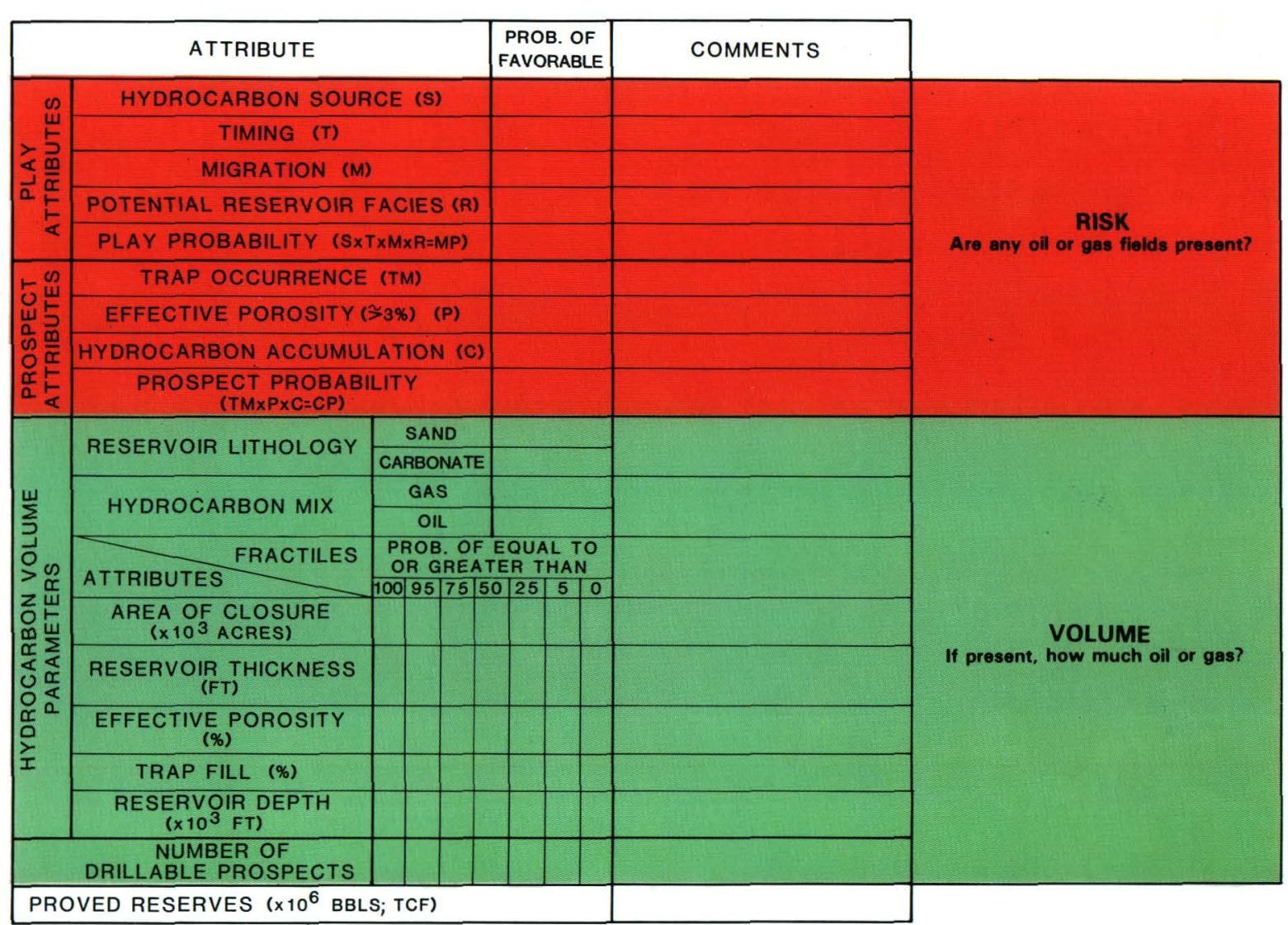


The traditional USGS method of estimating oil and gas resources, though successfully applied to two assessments of the Nation's resources within the past decade, did not supply the input required by the economic model constructed for the NPRA. A survey of other established methods turned up the play-analysis technique. The method employed in the NPRA was a modified version of this technique, developed by the Geological Survey of Canada to assess Canada's oil and gas resources. "Play" is an oil industry term describing an area where the prospective oil or gas deposits have similar characteristics, such as the same reservoir rock or a similar type of trapping mechanism.

In the play-analysis method, geologists make judgments on the geologic factors necessary to form an oil or gas deposit, and a computer generates the estimates. This arrangement utilizes the geologist's expertise with geologic factors and the computer's expertise with manipulation of numbers.

The geologist's judgments are recorded on a data form. An example of this form is annotated here to show how it answers the two fundamental questions asked in any assessment: (1) are there any oil or gas fields in the area and, if so, (2) how much oil and gas is present?

To answer the first question, geologists enter on the form probability judgments as to the favorability of the several factors necessary for an oil or gas deposit. These judgments are recorded on the upper half of the form (play attributes and prospect attributes). By multiplying all the probabilities together, an answer is obtained-the probability that oil and gas deposits are present. Oil companies use the term "risk" - the chance of failure-which is simply this probability minus one.

The lower half of the form addresses the second question. Here, geologists estimate a range of values for each of the five geologic factors needed to calculate the volume of oil or gas in a deposit.

In the NPRA assessment, a committee of 7 geologists established and assessed 17 separate plays. In assessing each play, the committee
METHOD OF REPORTING ASSESSMENT RESULTS

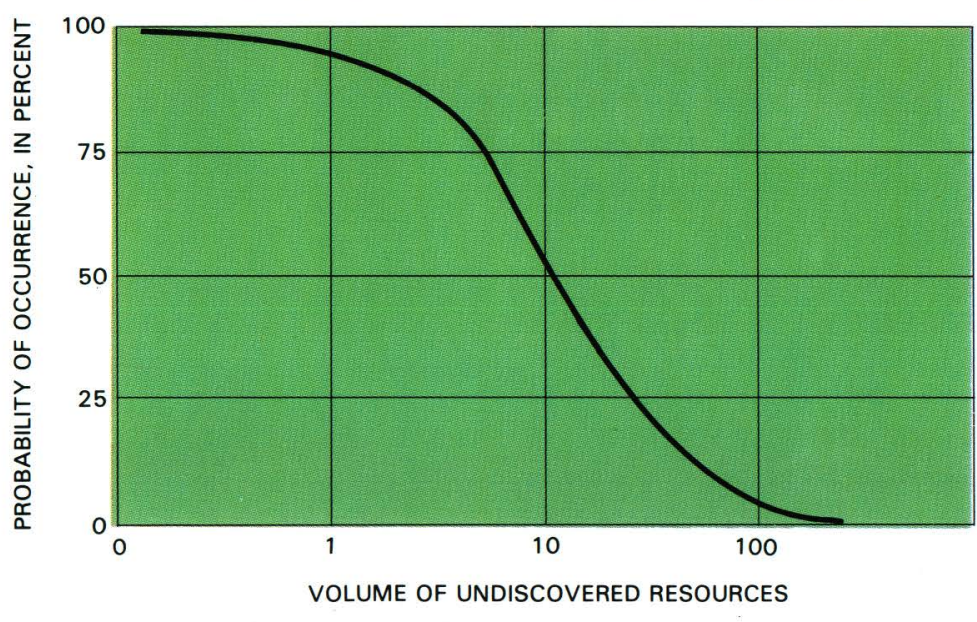

Probability curve showing the decreasing probability of petroleum occurrences with increasing volume of undiscovered oil or gas. reviewed extensive data summaries, representing many months of work by a team of geologists. A typical data summary for a play consists of several types of maps, cross sections, charts, and graphs. Such comprehensive data summaries are essential for an efficient and reliable assessment.

The computer, running a program called RASP generates the resource estimates by selecting and combining one possible value for each hydrocarbon volume factor (from the lower part of the form) to give one estimate for the oil and gas resources of the play. This process is repeated 3,000 times for each play in the assessment. The result is 3,000 different answers reflecting various combinations of values randomly selected from the formprocedure known as a Monte Carlo simulation. For each play, these answers are lined up from smallest to largest, and statistical values, such as the average, are calculated. From these calculations, the range of answers can be summarized on a single probability curve, such as the one shown here. By now, it should be clear that no single answer is possible to the question of how much oil and gas are present; instead, an infinite number of answers are possible, each with its own confidence level. For example, from the curve illustrated above, one may expect a 50 percent chance that at least 1 million barrels of oil are present. Larger amounts of oil correspond to lower probabilities - that is, less confidence that those amounts are present-and smaller amounts of oil to higher probabilities, or more confidence that at least those amounts are present. 
For all 17 plays in the NPRA, the amount of undiscovered inplace oil is estimated at 0.82 billion barrels at a 95-percent probability and $\mathbf{1 5 . 4}$ billion barrels at a 5-percent probabilty, for an average value of 5.97 billion barrels. The total amount of undiscovered inplace natural gas is estimated at $\mathbf{2 . 4}$ trillion cubic feet at a 95-percent probability and 27.2 trillion cubic feet at a 5-percent probability, for an average value of 11.3 trillion cubic feet. The contribution of each play to the average values for oil and gas is shown graphically here.

Although use of a computer and a complex data form give the illusion of better or more accurate estimates, they may, in fact, be no better than estimates by much simpler methods. Only time and continued exploration will tell the "correctness" of the estimates. What this method does, however, which many others don't, is to guarantee a systematic consideration of each of the factors necessary for an oil or gas deposit, to record these considerations, and to report the estimates of volumes and pool sizes in terms of probabilities.
ESTIMATED AVERAGE AMOUNT OF NATURAL GAS

IN PLACE FOR ALL OF NPRA

11.3 TRILLION CUBIC FEET

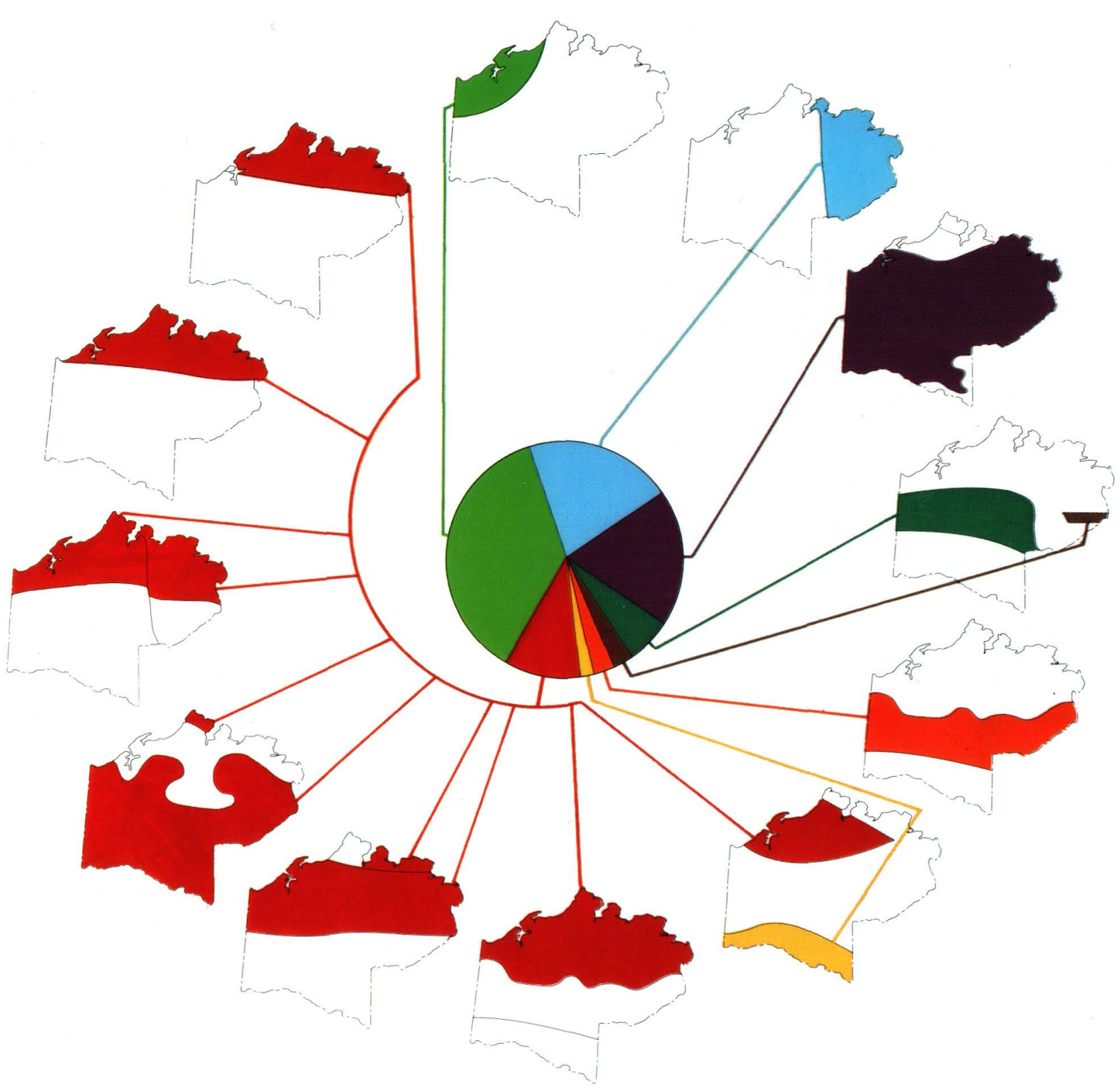

The proportion of the average amount of natural gas contributed by each of the 17 plays assessed (shaded area). 
ESTIMÁTED AVERAGE AMOUNT OF OIL

IN PLACE FOR ALL OF NPRA

5.97 BILLION BARRELS

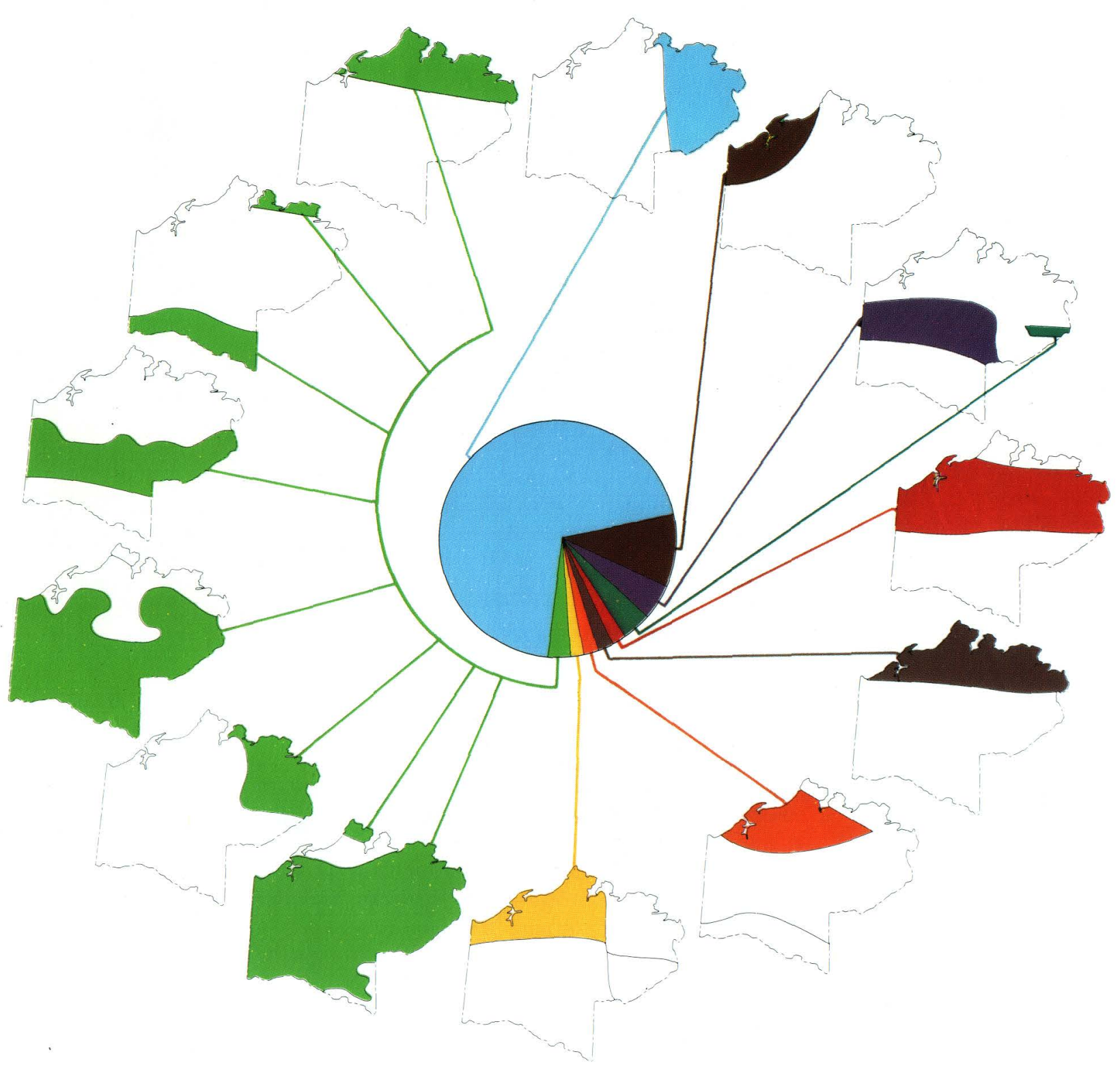

The proportion of the average amount of oil contributed by each of the 


\section{What were some of the geotechnical, engineering, and environmental considerations in the exploration and development of the NPRA?}

Petroleum exploration in a remote wilderness area, such as the NPRA, requires not only consid eration of the geologic factors but also special attention to climatic, geographic, and environmental aspects. The congressional mandate specifically called attention to environmental and cultural considerations and required studies (Public Law 94-258, secs. 105(a), 105(b)) of other resources, as well as of alternative management procedures and their economic and environmental consequences. These studies were completed by the U.S. Department of the Interior and submitted to the Congress as scheduled.

In the light of these special mandates and the Arctic wilderness setting, the USGS and the BLM agreed on procedures to be followed to accomplish the exploration with minimal impact on the environment. These procedures required careful and thorough advance planning and monitoring in accordance with prescribed environmental stip ulations. The final reports by the operating con tractors describe these actions in detail, and only a few highlights are included here.

\section{Surficial materials}

Surficial deposits in the NPRA consist mostly of fine-grained deposits-clay, silt, and sand. Gravel, the material required for constructing all-season drill pads, airstrips, and roads, is scarce and is confined to riverbeds along the slopes of the Brooks Range, the Colville River bed, and a few areas along the Arctic coast. In some places, long hauls were required to bring in satisfactory construction material; the same gravel may have been used repeatedly for drill pads in the Barrow gas fields, by moving it from one drill pad to the next.

Sand dunes are common in an area of the North Slope between the Meade and Colville Rivers. Although most of these dunes are no longer active and have been stabilized by a cover of vegetation, their shapes reflect the present wind direction, and they are thought to be of relatively recent age.

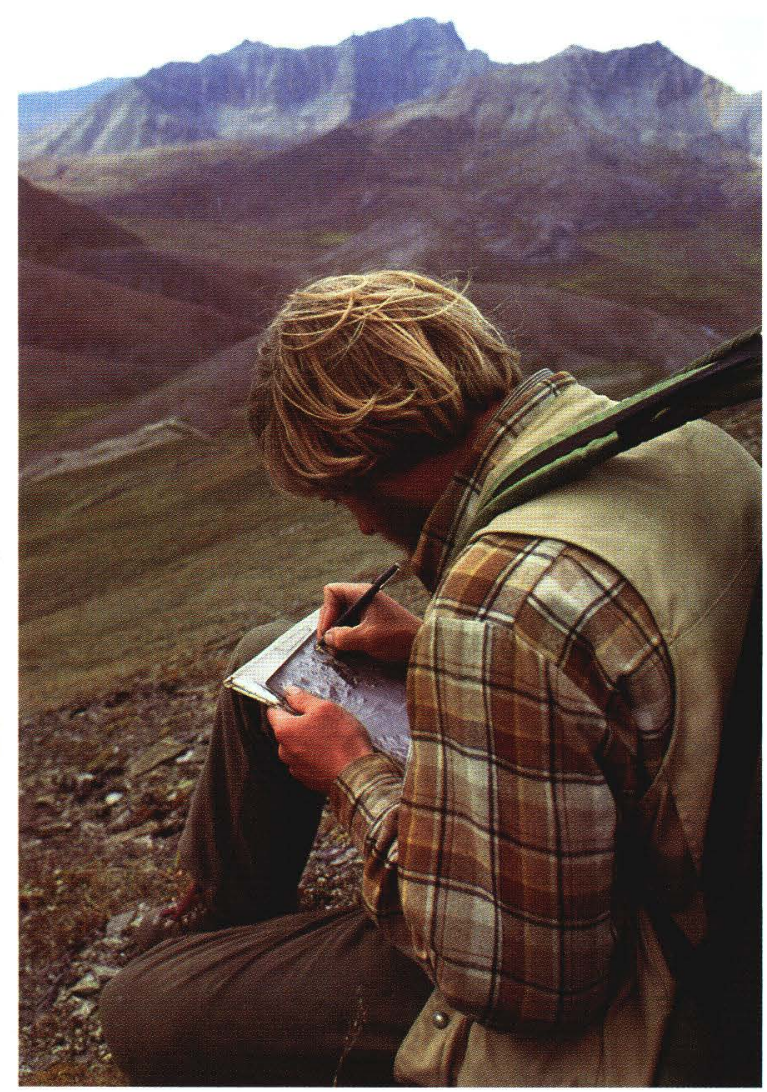

USGS scientist mapping in the Kelly River area, Brooks Range. Photograph by Jeep Johnson.

Quaternary surficial deposits and their distribution across the NPRA (modified from Williams and others, 1977). 


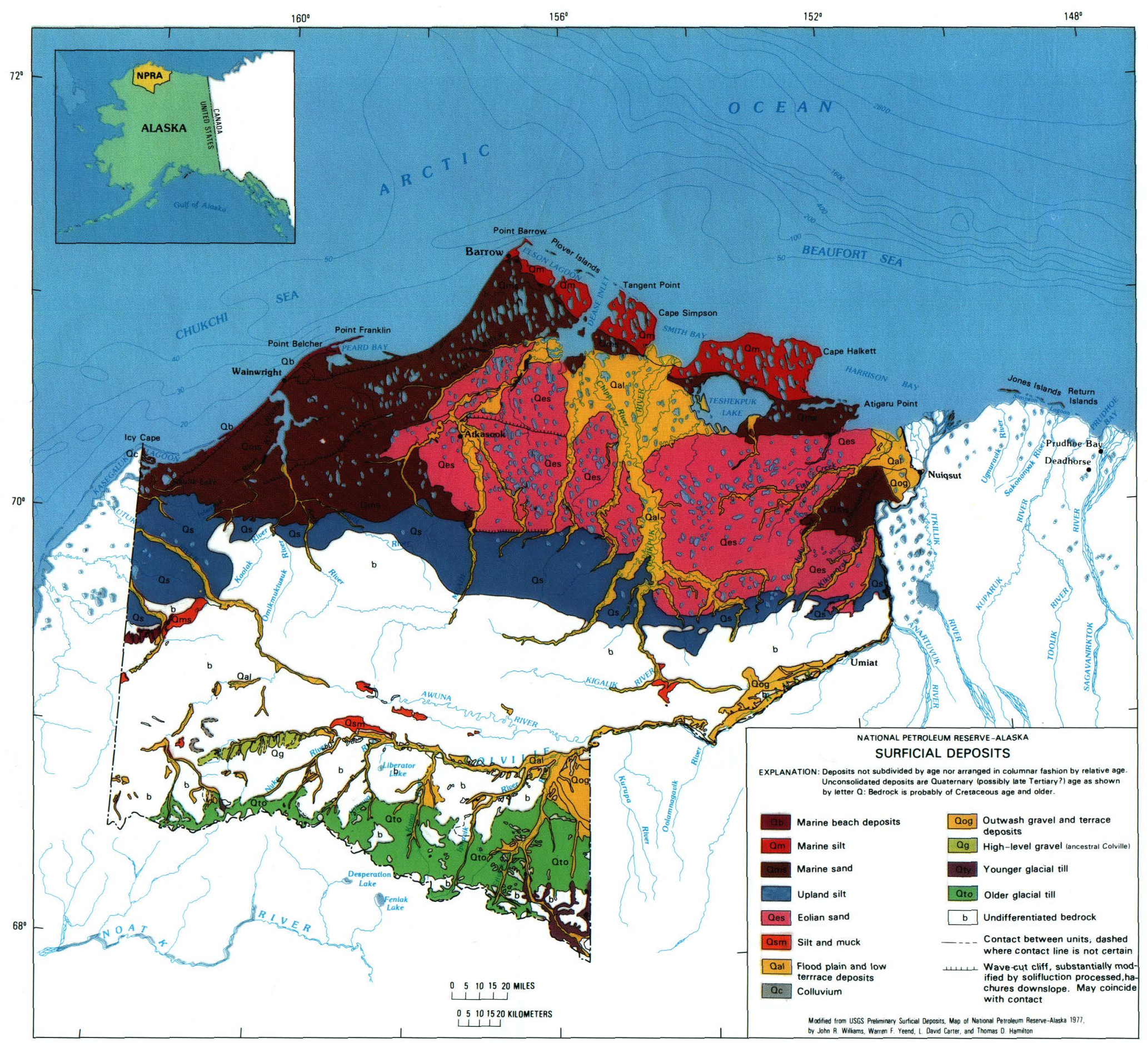


Although several episodes of widespread glacial activity occurred during the Quaternary, most authorities agree that the area north of the Brooks Range has not been glaciated. Localized alpine glaciers were present in the Brooks Range, and material eroded from the mountains by glacial processes was transported northward to the lower parts of the NPRA, where it was redistributed and deposited by streams and wind.

The extreme climate that has existed in northern Alaska throughout most of the Quaternary has resulted in intense frost action in the fine-grained sediment and the formation of perennially frozen ground (permafrost). The relatively young frozen sediment has preserved a rich and varied fossil record of plants and animals. Most of the fossils are found in deposits of Wisconsinan age (70,000 to 10,000 years ago). The most common vertebrate fossils are of mammoth, bison, horse, and mastodon. They are most abundant in river drainages and on valley floors, where the surficial deposits are thickest.

The Quaternary rocks also contain a record of human presence in northern Alaska. Although it is widely believed that the first humans came to North America by way of Alaska, no solid proof exists. Archeologic sites in Alaska have been radiocarbondated at about 8,000 or 8,500 years old. Ages of 12,000 to 15,000 years have also been suggested because the artifacts are similar to those found at older sites in Asia. Estimated deposition rates of stratigraphic layers between dated material and undated material some distance below corroborate the older ages.

Archeologists study prehistoric remains in their search to understand the culture of the humans who migrated into northern Alaska. This NPRA archeologic site has been dated at 8,000 to 8,500 years old. These excavations were part of a larger archeologic study in the NPRA. Photograph by Jeep Johnson.

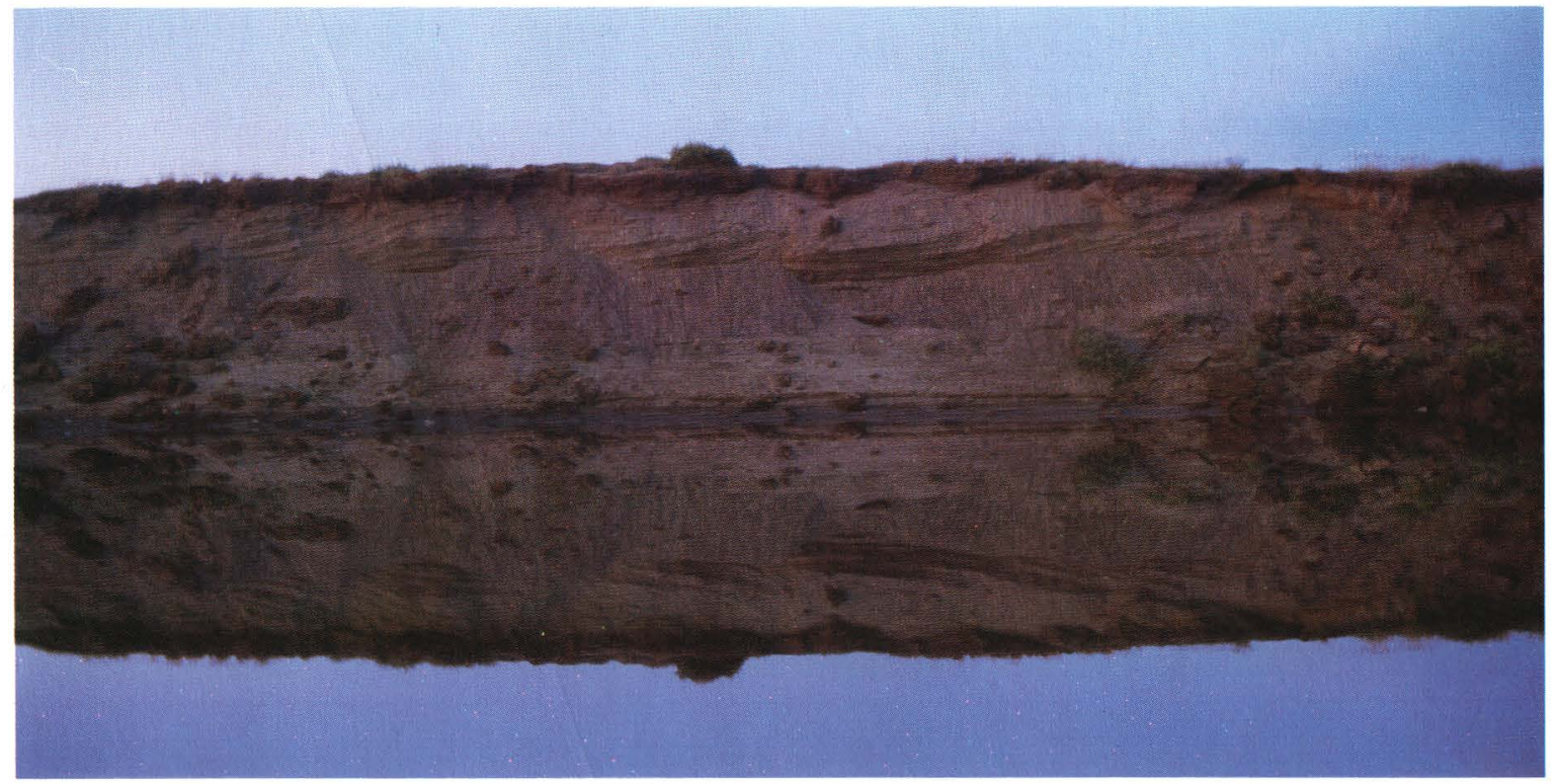

Quaternary river sand and gravel are commonly exposed by relatively recent erosion. Photograph by John Schindler.

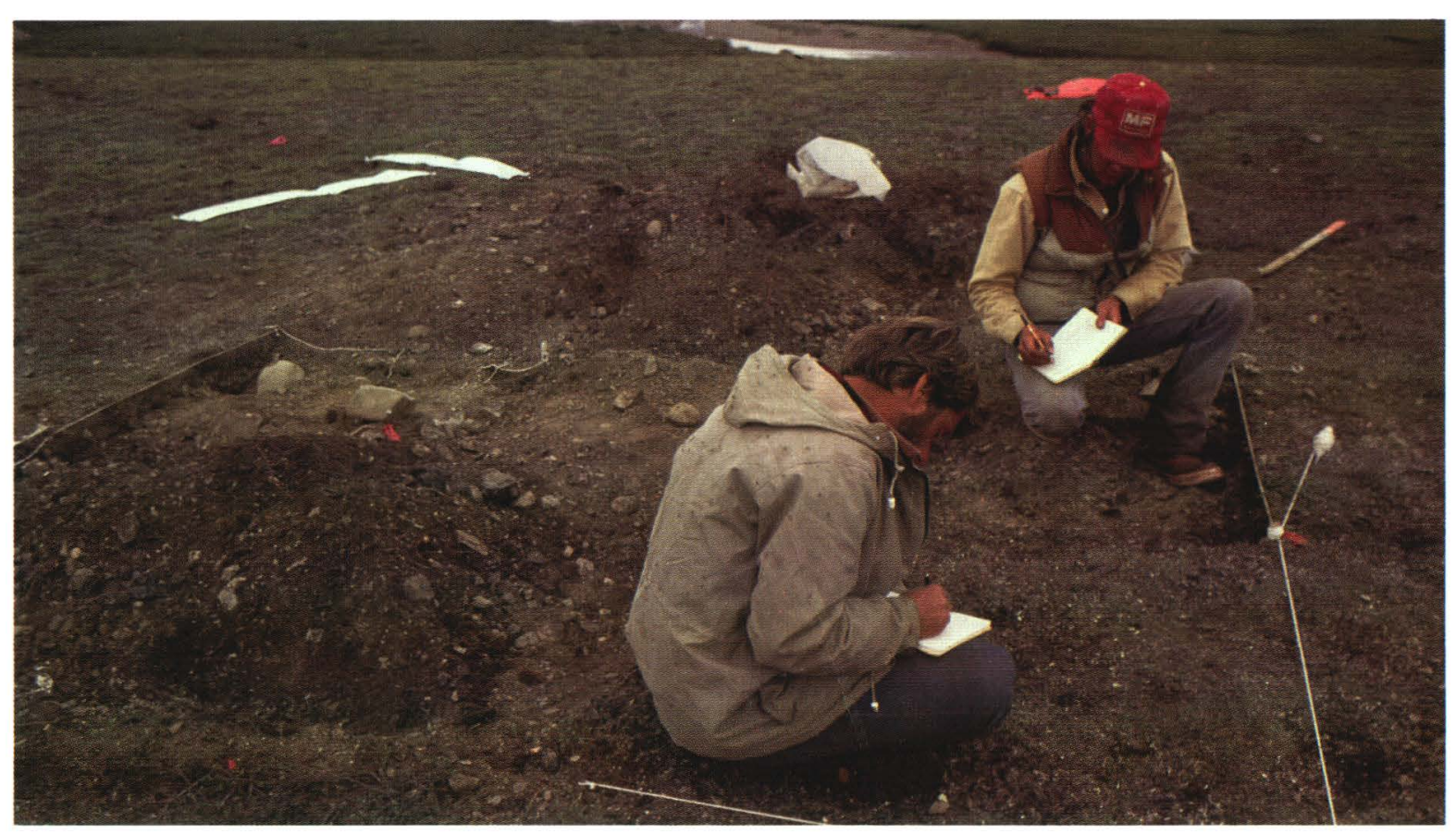




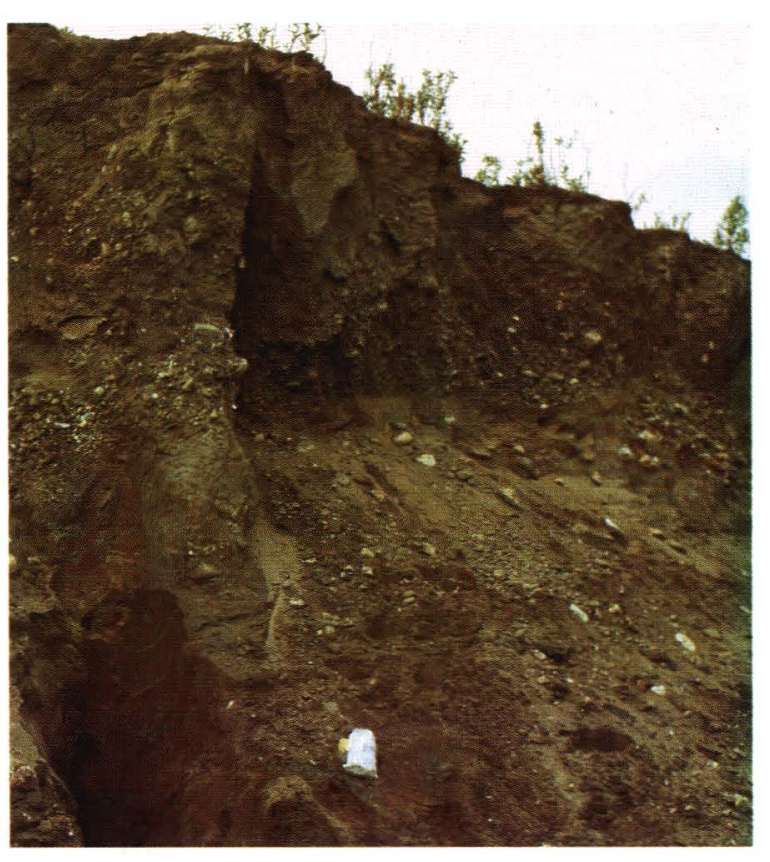

Kiana borrow pit. Gravel, the material required for the construction of roads, drill pads, and airstrips, is very scarce in the NPRA. Photograph by Irvin Tailleur.
Quaternary life on the North Slope once included bison, mammoth, horse, mastodon, lynx, and many other animals and plants now extinct, or gone from the North Slope. It has been suggested that the increasing numbers of early humans living here after the last major ice age led to the demise of many of these species.
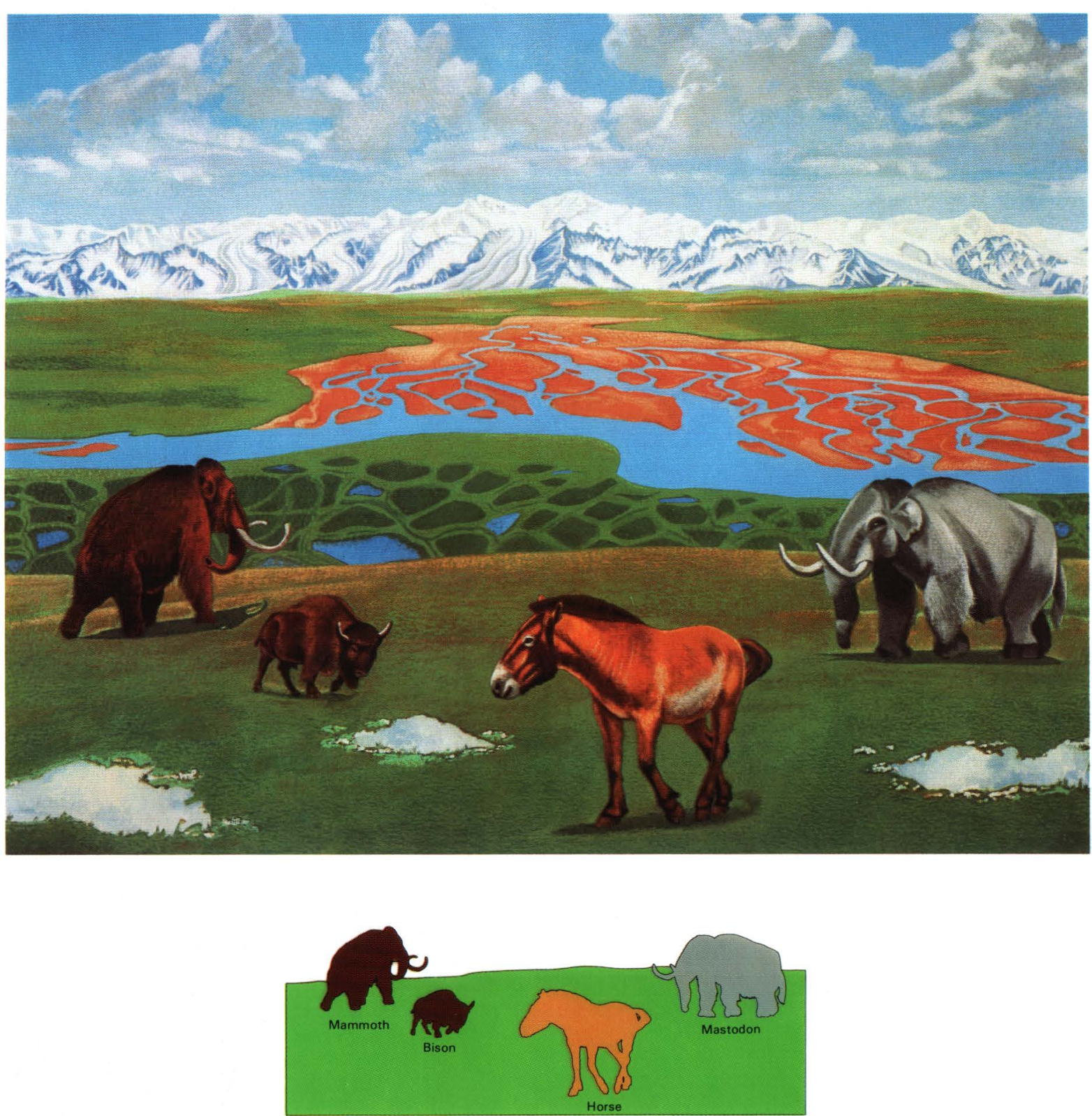

THE NATIONAL PETROLEUM RESERVE IN ALASKA 


\section{Permafrost}

Because the NPRA lies north of the Arctic Circle, the extreme Arctic climate causes the formation of permafrost. Permafrost is present wherever ground temperature remains continuously below $0^{\circ} \mathrm{C}$ for years. It can cover an entire region, such as the North Slope, or be discontinuous, as in southern Alaska. Nearly all of the NPRA is underlain by permafrost, above which is the "active layer"-all the material that thaws in the summer and refreezes in the winter. The thickness of this active layer varies with local conditions but in the NPRA ranges from 2 to 4 feet. The active layer forms a boggy, swampy surface during the summer thaw. The extreme
Arctic climate of northern Alaska dates back to the pre-Quaternary ( 3 million to 2.5 million years ago), and so permafrost has been present for a long period.

There is little or no mineral cement or binding in the fine-grained surficial sediment. The individual grains may be surrounded by ice, resulting in icerich permafrost. Permafrost is said to be ice rich when it contains more water in the form of ice than the ground could possibly hold if the water were liquid. In general, the Arctic Coastal Plain is underlain by ice-rich permafrost. If the ice melts, settling problems can be extreme and thus present a great engineering challenge.

Permafrost is the dominant factor that influences the design, engineering, construction, and transportation phases of any operation in the Arctic. Because ice is impermeable, there is no vertical drainage below the thin active layer. The base of the active layer is an irregular surface that ponds water during the thaw, and so in areas of steeper slopes, the water-saturated sediment is ready to start sliding downhill at the least disturbance, and mudslides are common. During the warm months, the wet, soggy tundra is difficult to walk on and impassable for most ground vehicles. In the past, heavy tractors with "caterpillar" belt treads have been used in the summer, sometimes with the bulldozing blade down to remove soft tundra. Some tractor scars are still visible and still eroding after 40 years, and so

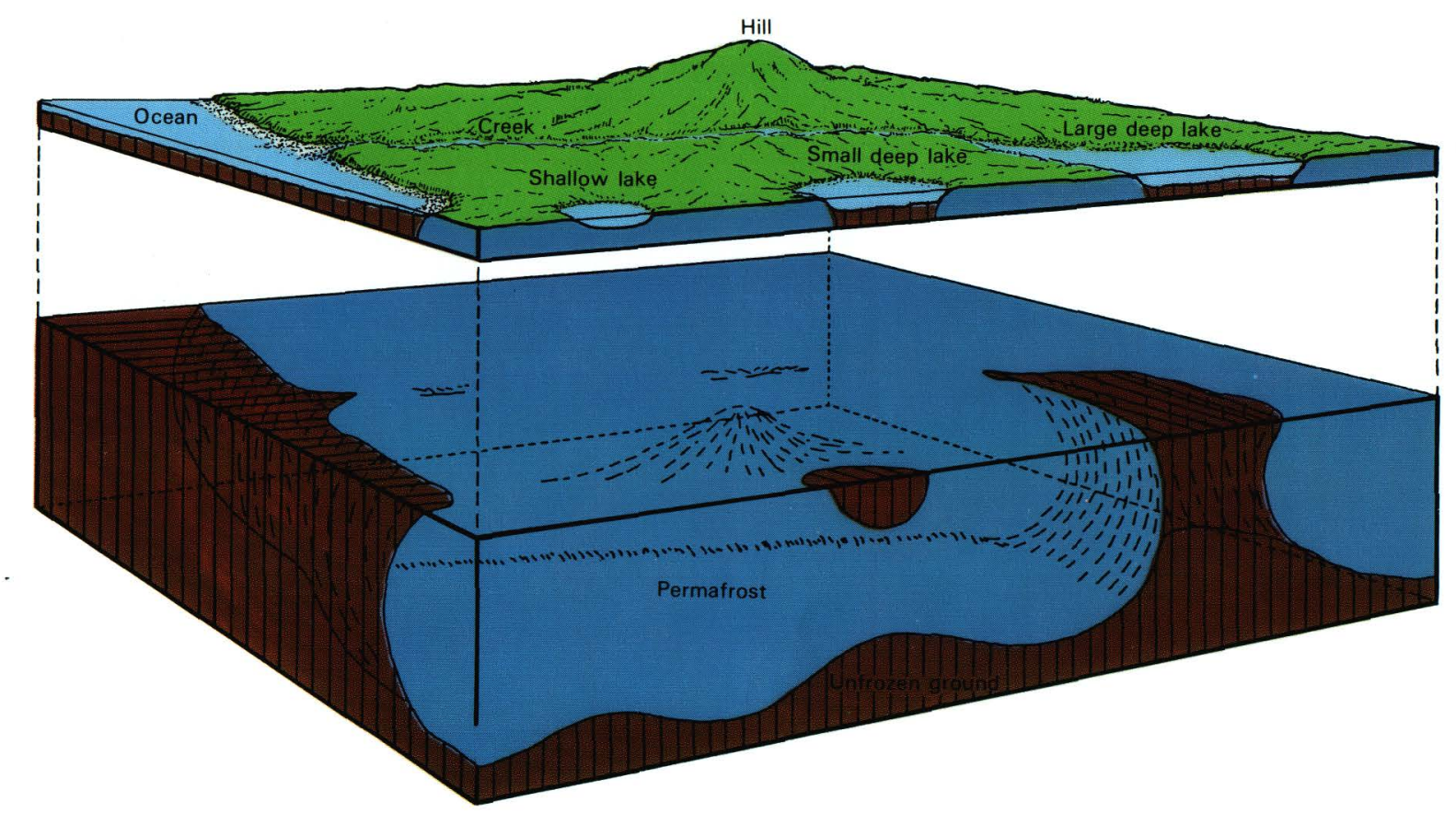

All of the NPRA is underlain by a nearly continuous zone of permafrost. This diagram shows the effect of surface features on the distribution of permafrost. Only the area beneath Lake Teshekpuk, the largest lake in the NPRA, lacks a permafrost zone (adapted from Ferrians and others, 1969). 
alternative means have been developed for summer ground transport. Large ground vehicles now use wide balloon tires that increase the area of the "footprint" and thus decrease the pressure exerted on the tundra.

Most activity in the NPRA involving heavy equipment takes place after the tundra has frozen and is protected by a snow cover. The surface can then be used for transportation, and little or no damage is caused. Ice roads can be built for the use of surface vehicles. Large or permanent structures are placed on pilings well above the tundra surface, so that they do not form a "thaw bulb" in the upper surface of the permafrost and create engineering problems or unsightly reminders of human activities. However, drill pads and roads must be carefully located, so that natural drainage is disturbed as little as possible, or else erosion will occur. Aircraft run ways are located on frozen lakes wherever feasible Permafrost affects all facets of Arctic operations but, as demonstrated by this program, the problems can be solved.

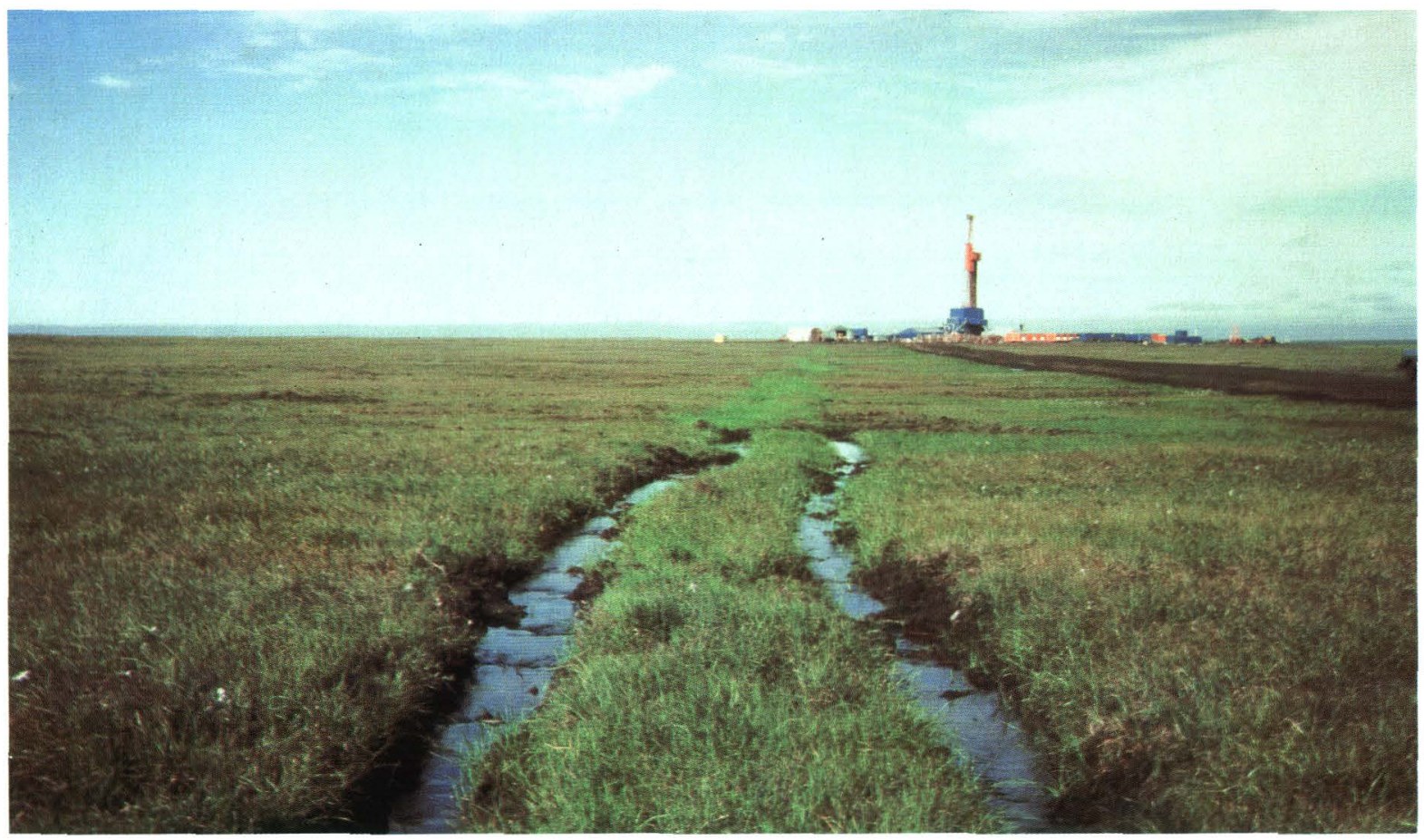

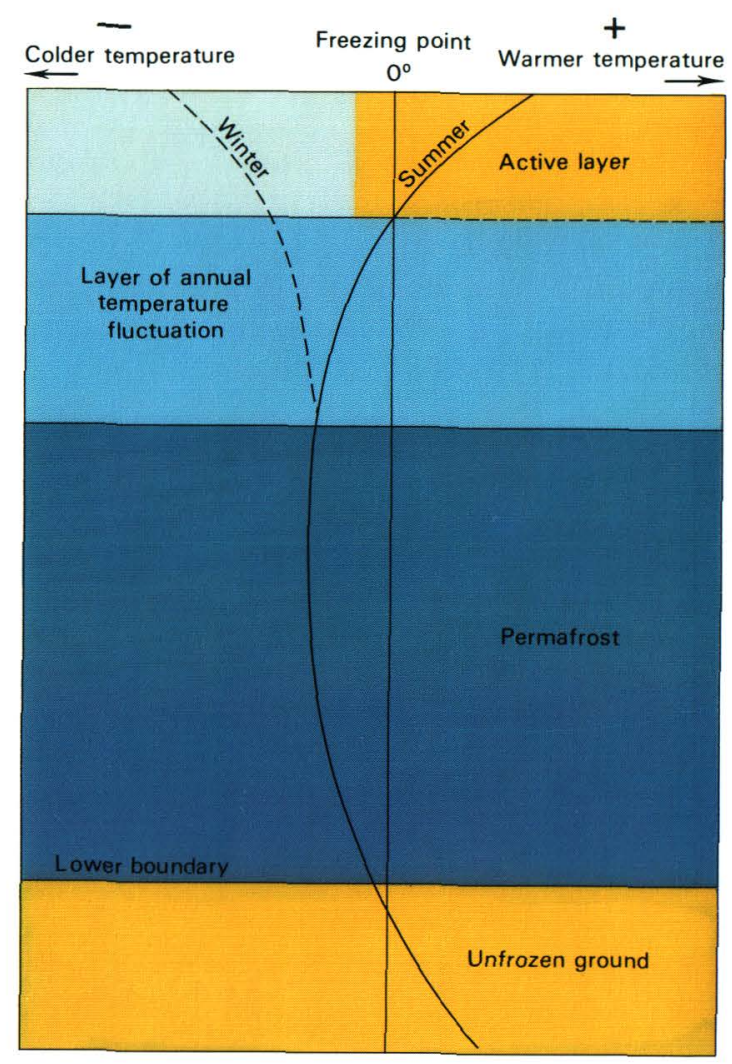

Generalized graph of ground temperature versus depth. In the Arctic, annual temperature ziariation smay be detected to a depth of $7010100(0)$ feet. The lower boundary for permanently frozen ground is about 1,000 feet at Barrow and 2,000 feet at Prudhoe Bay (modified from Haugen and Brown, 1971 
Permafrost contributes to the development of certain ground phenomena that are immediately apparent even to the most casual observer-such as polygonally patterned ground and oriented lakes. Patterned ground is the surface manifestation of vertical ice wedges. The ice wedges are thought to form in contraction cracks in the tundra that fill with water during the summer thaw and refreeze and expand during the next winter. Thus, over time, the vertical ice body is enlarged until a condition of relative equilibrium is reached. The cracks intersect in irregular patterns, but the most common are five-sided polygons.

Oriented lakes, strikingly evident on maps of the coastal plain, are believed to result from the interaction of prevailing northeasterly winds and ice. The long axes of these lakes are at right angles to the prevailing wind direction. During the spring thaw, the lake ice melts along the shore first, leaving a moat of water surrounding an ice island. As the wind velocity fluctuates, this ice island moves back and forth in response to the windforce and wind direction. The water is forced around the ends of the ice and erodes the ends of the lake, and thus elongates the lake basin at right angles to the direction of the prevailing wind.

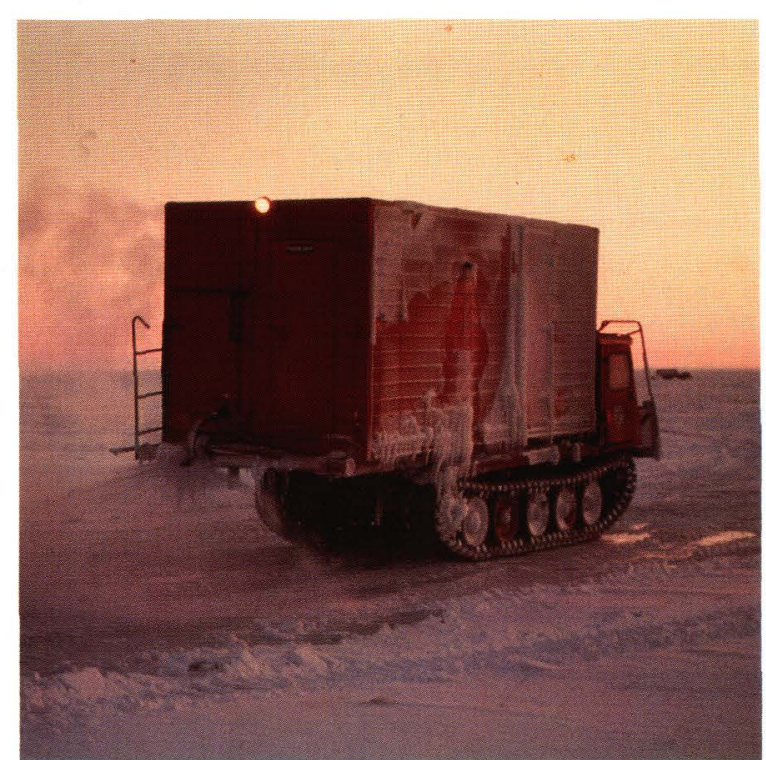

"Resurfacing" an ice road at South Simpson. Using ice roads for transporting heavy equipment during the winter months prevented lasting damage to the tundra. Photograph by John Schindler.

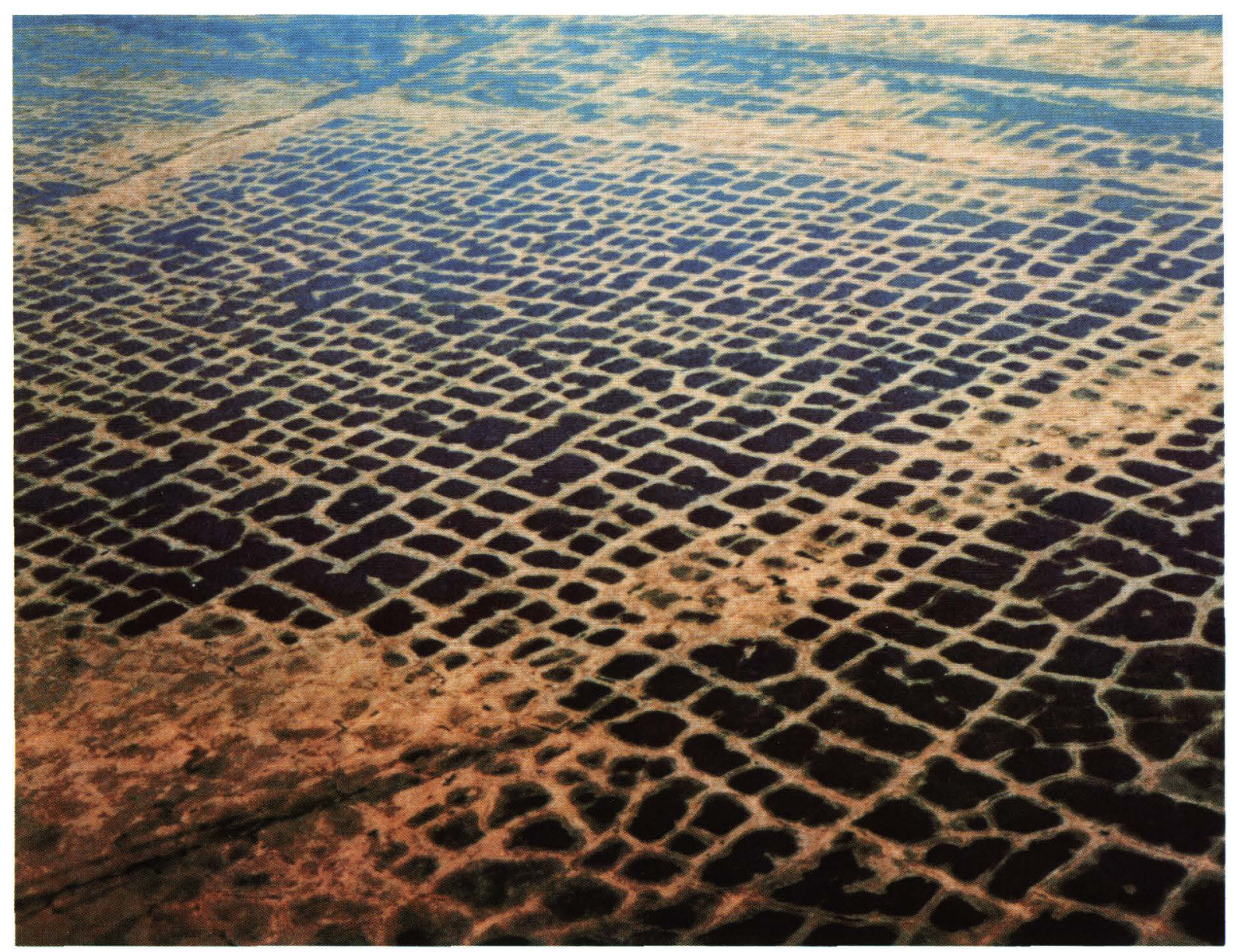

Polygonal or patterned ground results from ground contraction during extremely low winter temperatures. Water and snow that collect in the contraction cracks eventually turn to ice and create intersecting ice wedges that surround each polygon. Photograph by Jeep Johnson. 


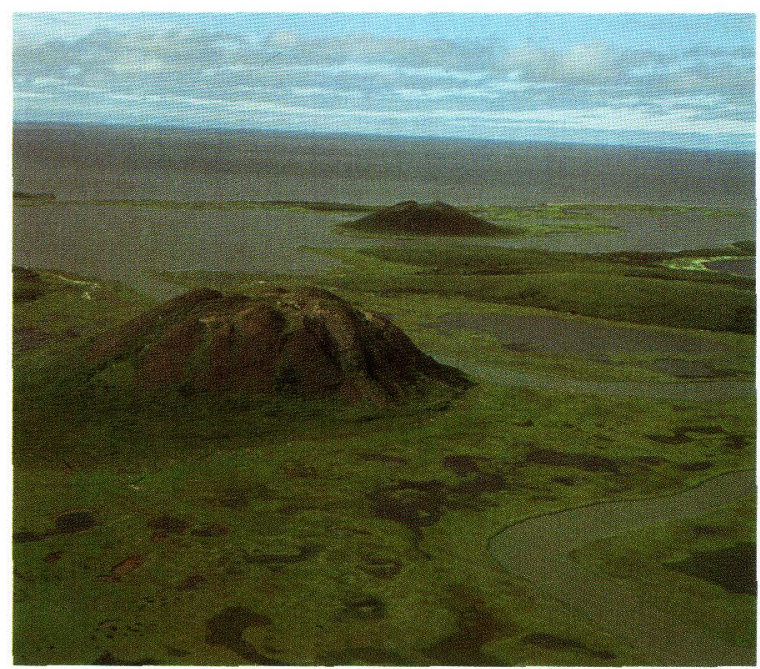

Rounded hills with ice cores, called pingos, commonly form in the centers of drained lakes as the water-saturated soil freezes inward from the basin sides. When the center finally freezes, the ice can only expand upward and forms a low hill. Photograph by George Gryc.

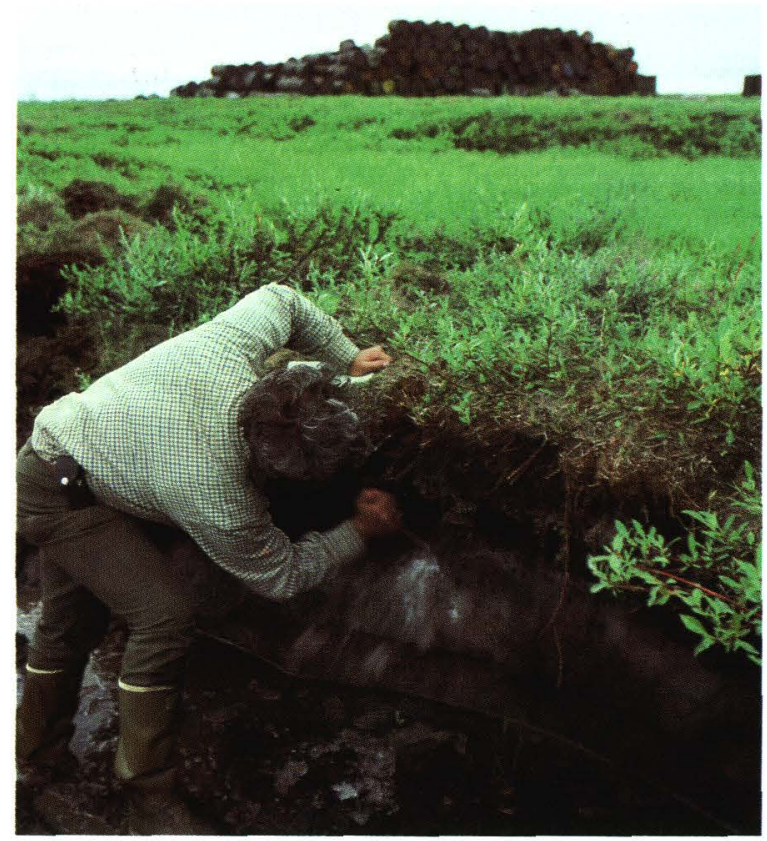

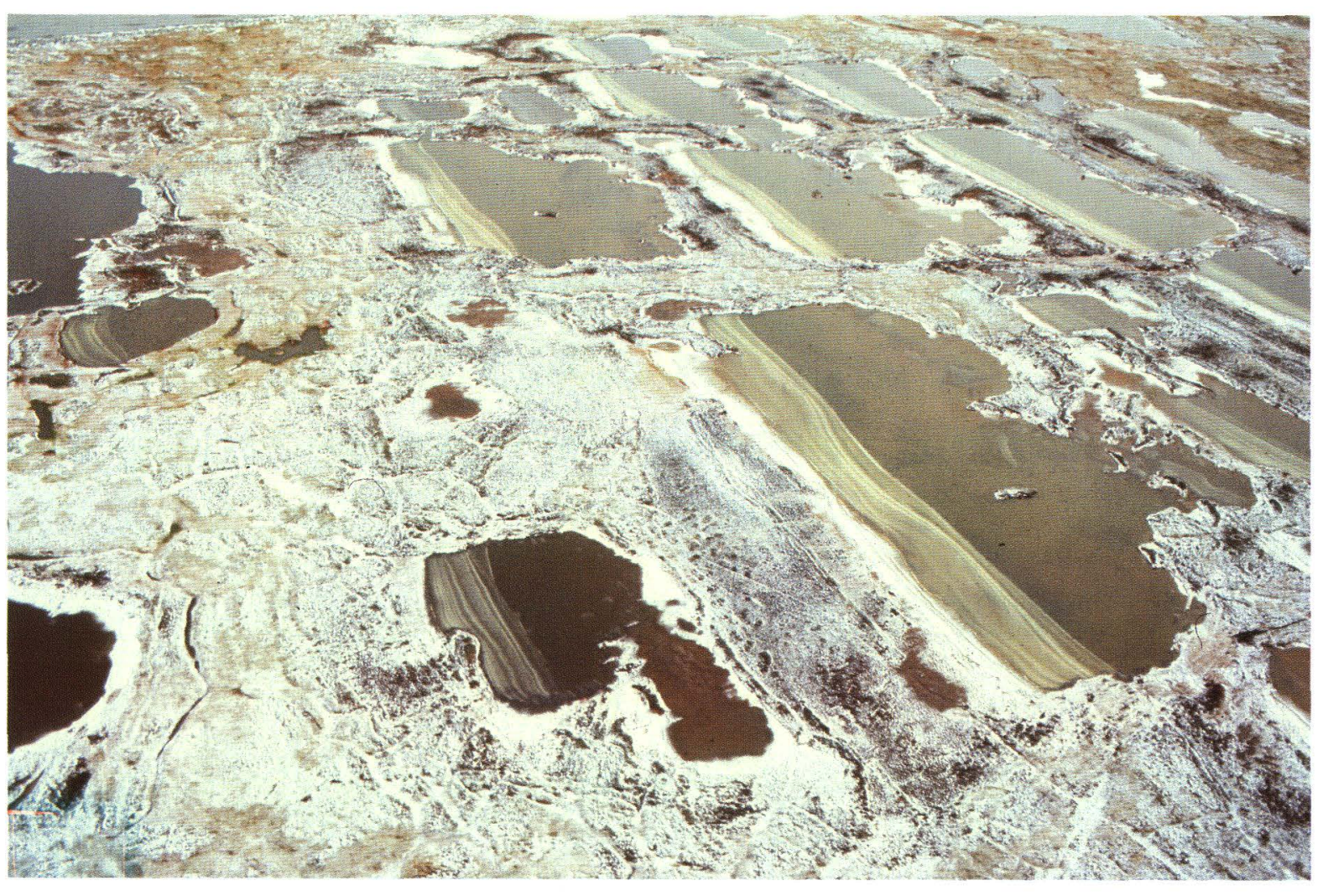

Oriented lakes result from interaction of the prevailing northeasterly winds with the lake ice. Photograph by George Gryc.

Sampling a small ice wedge beneath the tundra cover. Photograph by Jeep Johnson. 


\section{Environmental stipulations and monitoring}

The Naval Petroleum Reserve Production Act of 1976 (Public Law 94-258) made specific reference to protecting the environment. Recognizing that the NPRA is underlain by permafrost and thus is most sensitive to any actions that alter the surface, the USGS and the BLM met together and drafted an MOU that defined the responsibilities of each agency.

Because knowledge about the characteristics of permafrost is not widespread, it was decided that the USGS would draft a set of stipulations governing surface activities and movements which would be rigidly followed during the exploration program. Monitors representing both the USGS and the BLM were to continuously observe all activities. Under the provisions of the MOU, the USGS prepared each year an Annual Plan of Operations that specified the locations of all wells proposed for the year, their estimated total depth, construction designs, timetables for all operations, and, possibly most important, the exact routes to be used by the construction crews.

When the annual plan was completed, site-specific environmental assessments and engineering surveys took place concurrently. Thus, the construction and drilling designs incorporated specific environmental considerations tailored to the conditions at each site. Environmental surveys were conducted during the summer and included gathering soil and surface information, as well as locating water sources and borrow sites. The areas were also checked for potential conflicts about archeologic, fishery, and wildlife problems. For example, borrow sites were relocated if a suspected archeologic site was involved, or the site was thoroughly examined and recorded by archeologists before being disturbed. Furthermore, the operational schedules were adjusted to cause minimal effect on wildlife-sensitive areas, such as waterfowl habitats, caribou-calving grounds, and falcon-nesting places. Such environmental factors were considered at every site

\section{ENVIRONMENTAL STIPULATIONS}

1. Heavy equipment may be transported on winter roads only after the tundra is seasonally frozen to a 12 -inch depth, and must cease when daytime spring melt of snow begins.

2. No bulldozing of tundra areas for roads or trails.

3. Camps may be located on solidly frozen ponds or lakes, provided that no toxic or hazardous materials are allowed to be dumped onto the ice.

4. Exploration activities will employ low-ground-pressure vehicles.

5. No historic site, archeologic site, or camp, either active or abandoned, shall be disturbed in any manner.

Some of the basic environmental stipulations governing surface activities in the NPRA, taken from the MOU.

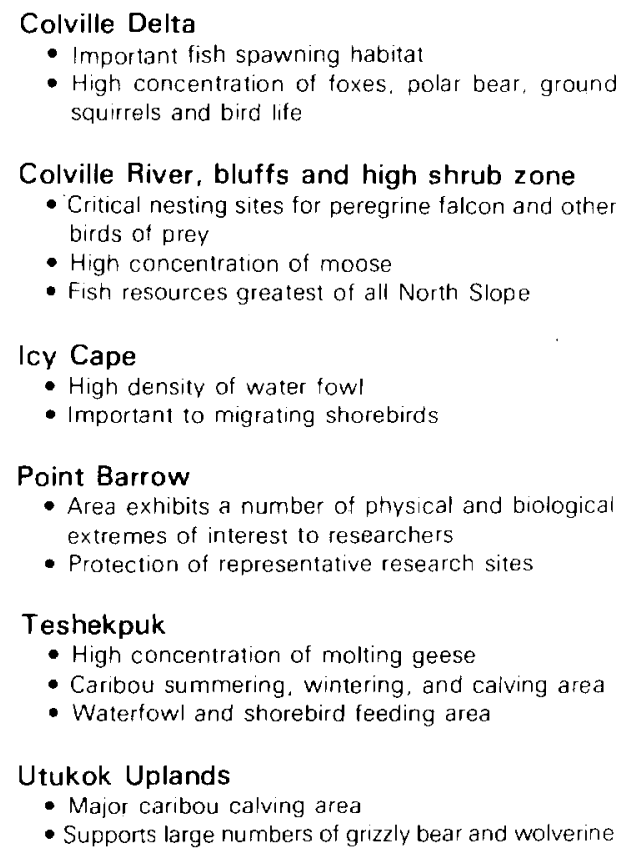

Unique ecologic areas in the NPRA (modified from National Petroleum Reserve in Alaska Task Force, 1978). 


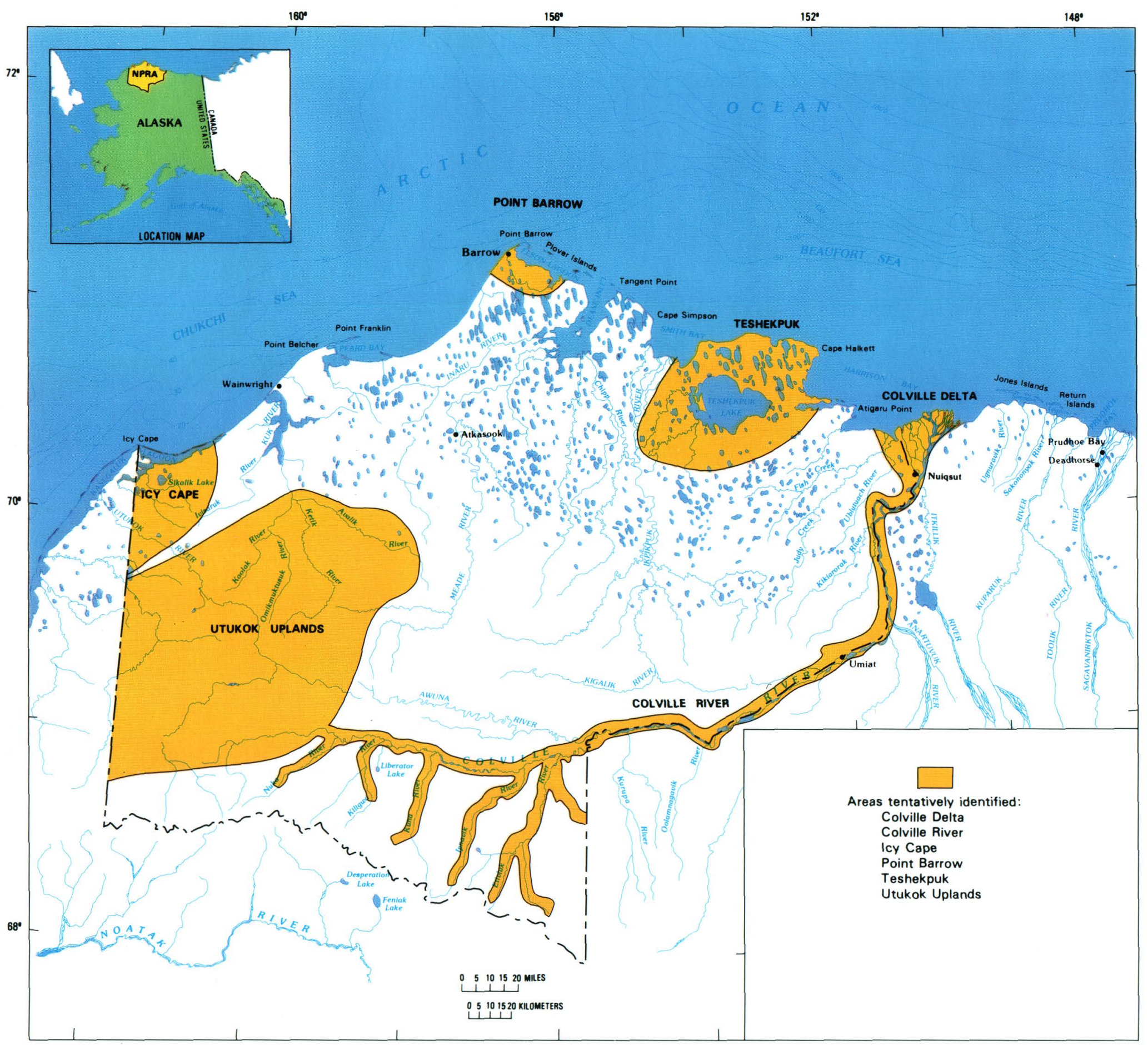

THE NATIONAL PETROLEUM RESERVE IN ALASKA 
The 1977-82 exploration program was designed so that most action took place during the winter months, to minimize environmental disruptions. Because tundra, when frozen and protected with snow cover, makes a good working surface, seismic operations and road and trail construction were largely restricted to the winter season and were rigidly controlled.

A few environmental problems arose, but promptly corrected, at the 28 exploratory wells drilled during the $1977-82$ program: minor fuel leaks and spills at the drillsites and from the mobile trains, a few instances of improper waste-water treatment, and insufficient protection for the tundra during the burning off of small amounts of waste oil. Only two problems were significant: one was the difficulty of reestablishing the vegetative cover in the coastal marine environment, and the other the seepage of fluids through the berm surrounding the reservoir pit at the Inigok site. This seepage resulted in some damage to the tundra vegetation, but it is recovering. It was found that planting tundra bluegrass, with plenty of fertilizer added, speeded the recovery.

The environmental impact of the program was minimal to both the land surface and the wildlife. Only about 250 acres was affected by drill pads and reserve pits, and another 168 acres by borrow sites. In addition, about 105 acres was covered over with permanent runways, 15 acres was used as burial sites for old debris, and about 3 acres was occupied by all-season roads. The total acreage disturbed was about 540 acres-only 0.00227 percent of the 23,680,000 acres of the NPRA. About 95 percent of this 540 acres will be difficult to identify within 3 to 5 years. Only the permanent runways and roads will remain in 20 to 25 years as a result of the 1974-82 exploration activities in the NPRA.
Grazing caribou near the Lisburne wellsite. Photograph by Jeep Johnson.

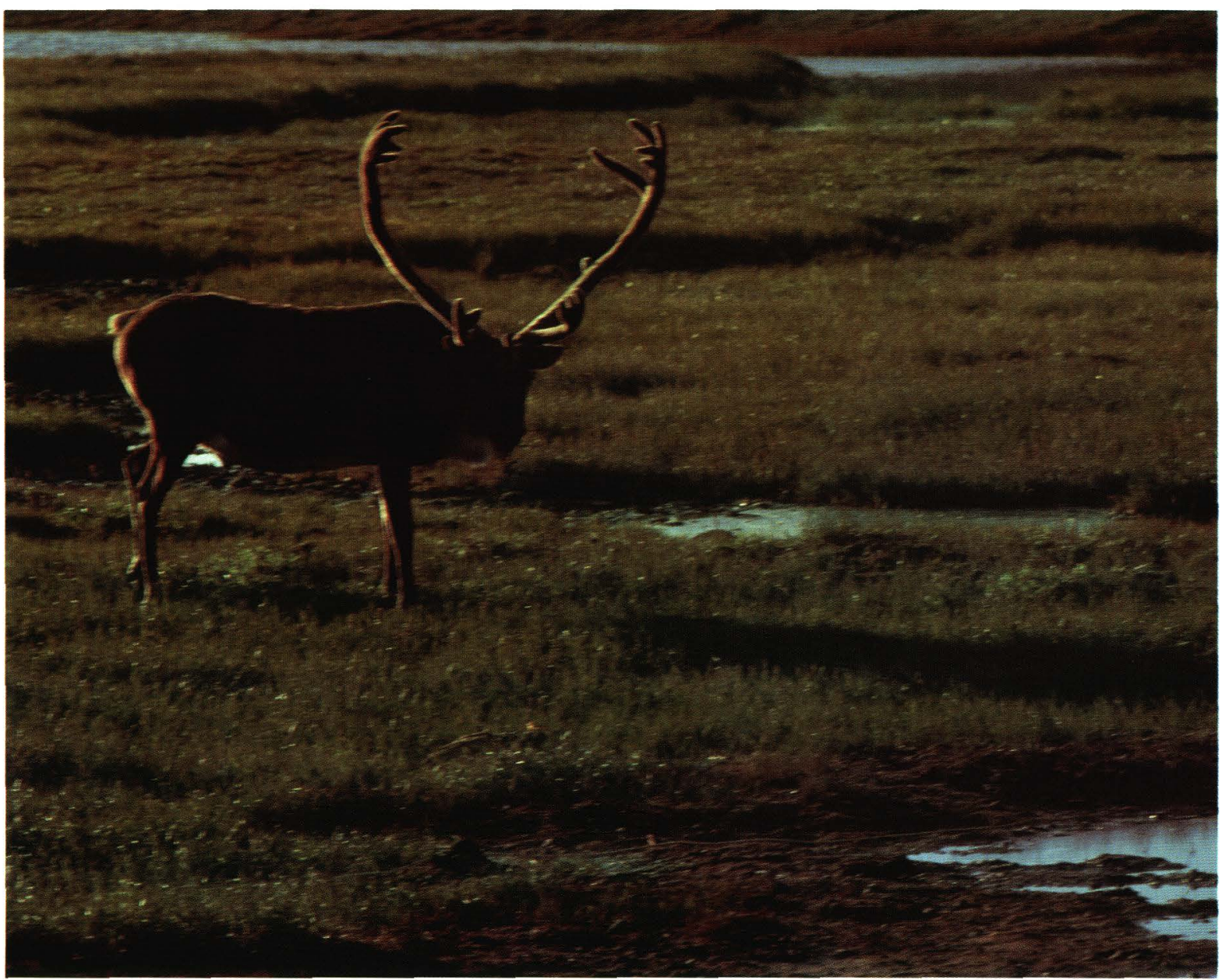




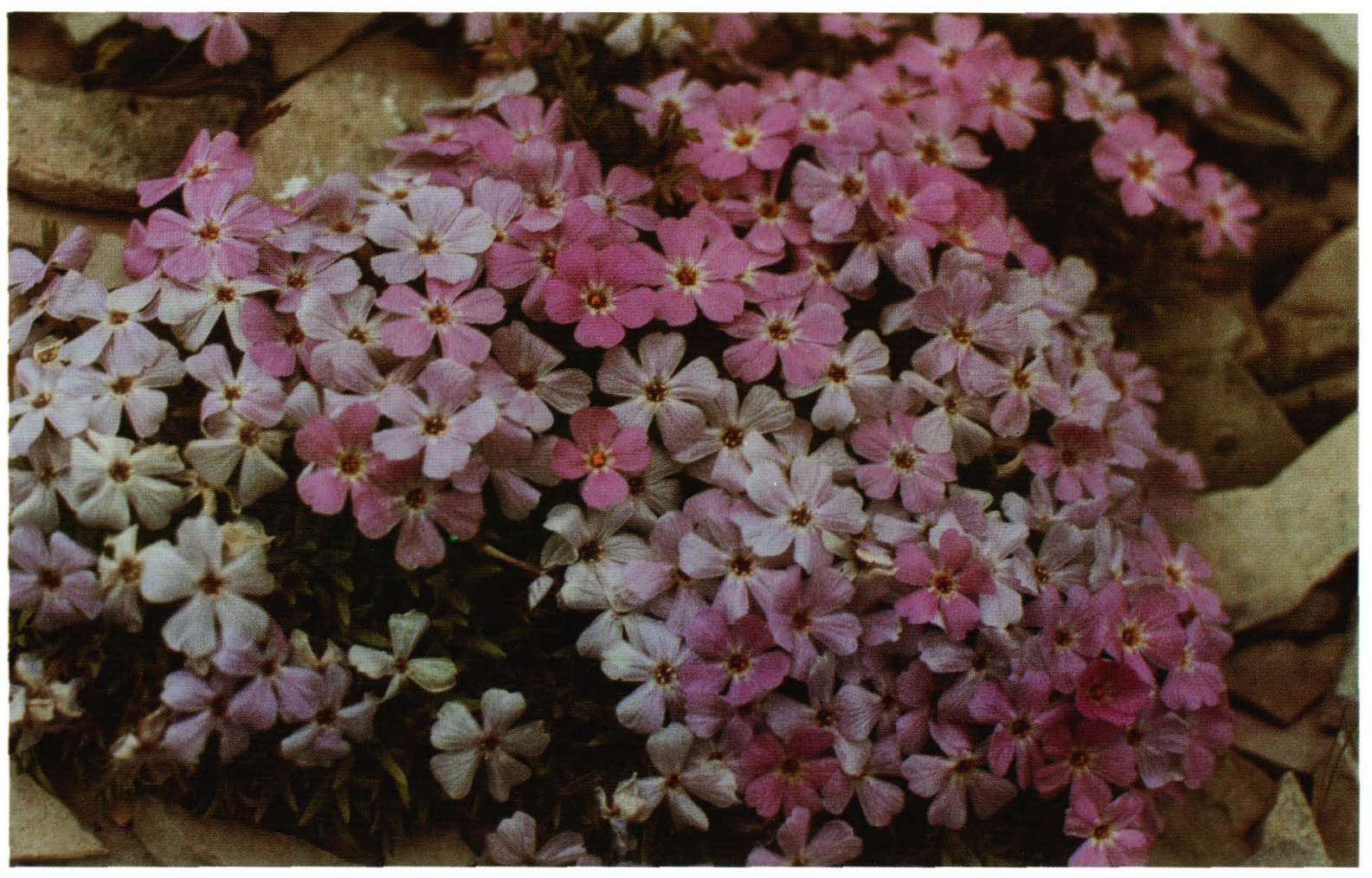

Cushion pink (Silene acoulis) with its long, strong roots anchors

itself firmly on rocky mountain summits.

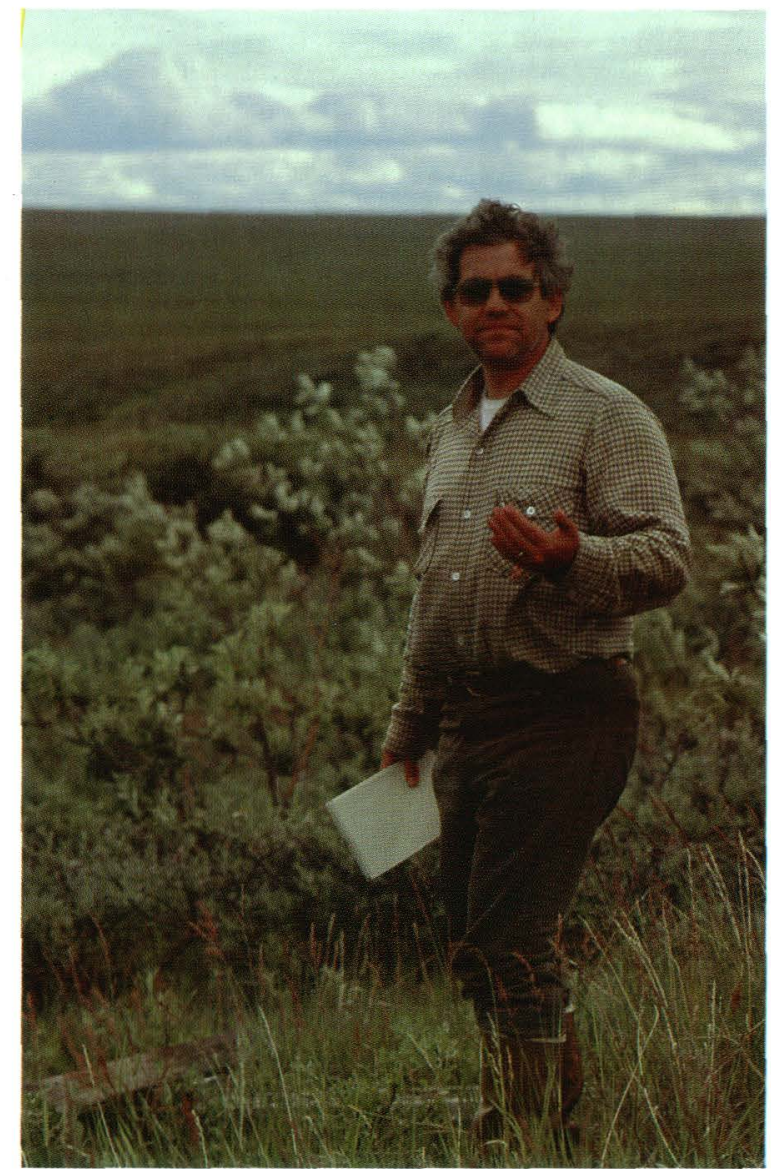




\section{Trafficability and movement of supplies and materials}

In the NPRA and elsewhere on the North Slope where no permanent roads exist, winter is the best time for overland movement. During the earlier petroleum-exploration program of 1944-53, caterpillar-type tractors were the principle pieces of equipment used to transport large items. Today, they are supplemented by rolligons and other vehicles with rubber tires. Aircraft were used occasionally during the earlier U.S. Navy exploration but became the principle means of transportation during the exploration program described here.

Land traffic was carefully restricted. Overland travel was allowed only after the ground was frozen and snow covered, and before the beginning of the spring thaw. Bulldozing was allowed to level snowdrifts, but the dozer blade was always kept above the tundra surface. Vehicles were selected for their low-ground-pressure qualities. The tundra was further protected by using only selected trails, and repeat runs were required to offset previous tracks, to avoid rutting. Frozen lake surfaces were used as much as possible, and banks were crossed at low angles to minimize damage. The challenge was to transport thousands of tons of machinery, drilling mud, pipe, fuel, and other supplies to remote drillsites; to construct all the needed facilities; to drill a wildcat well; and then to move off the site, leaving a minimum imprint on the area.

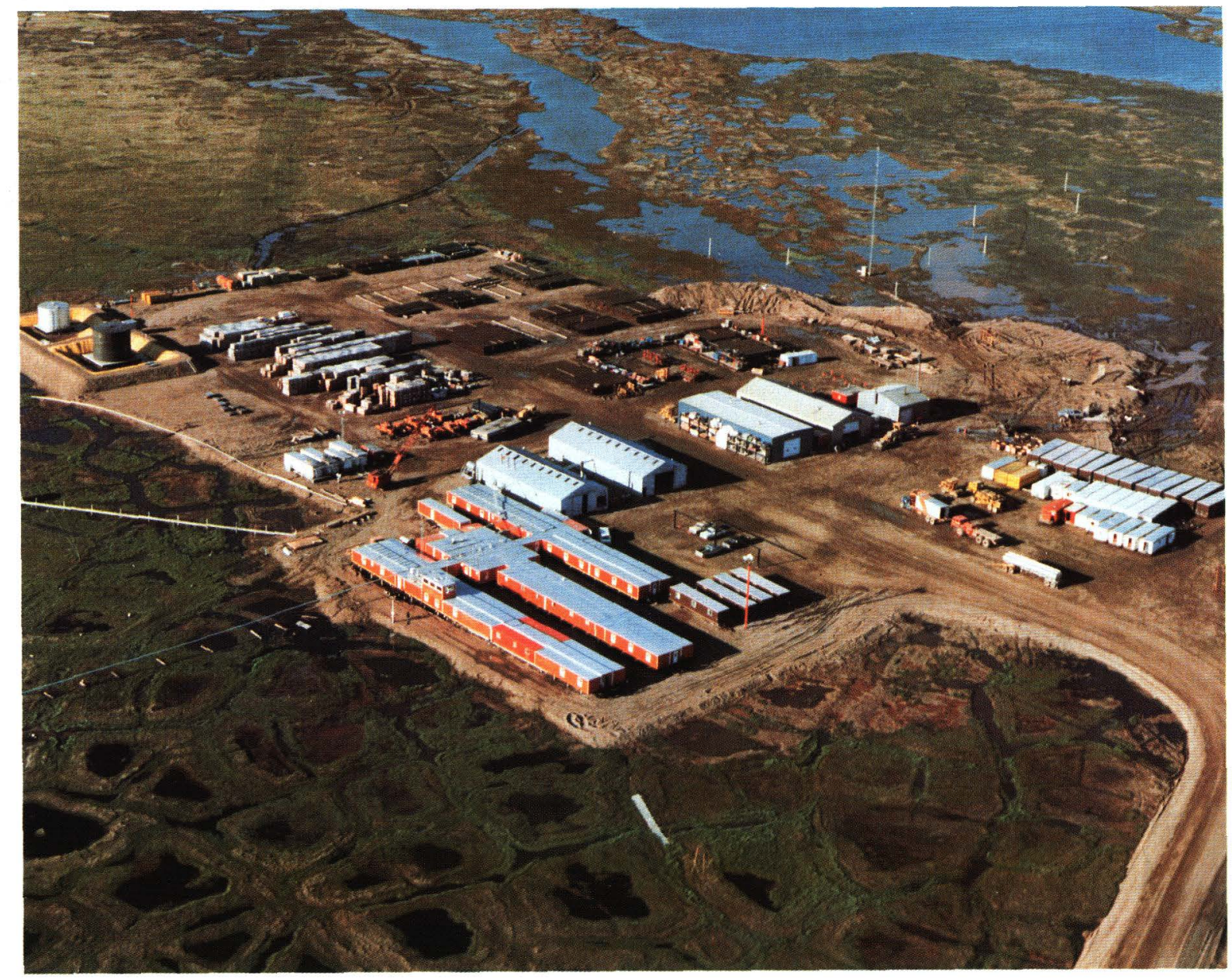

Aerial view of Lonely, the "hub" of the exploration effort. Photograph

by John Schindler. 

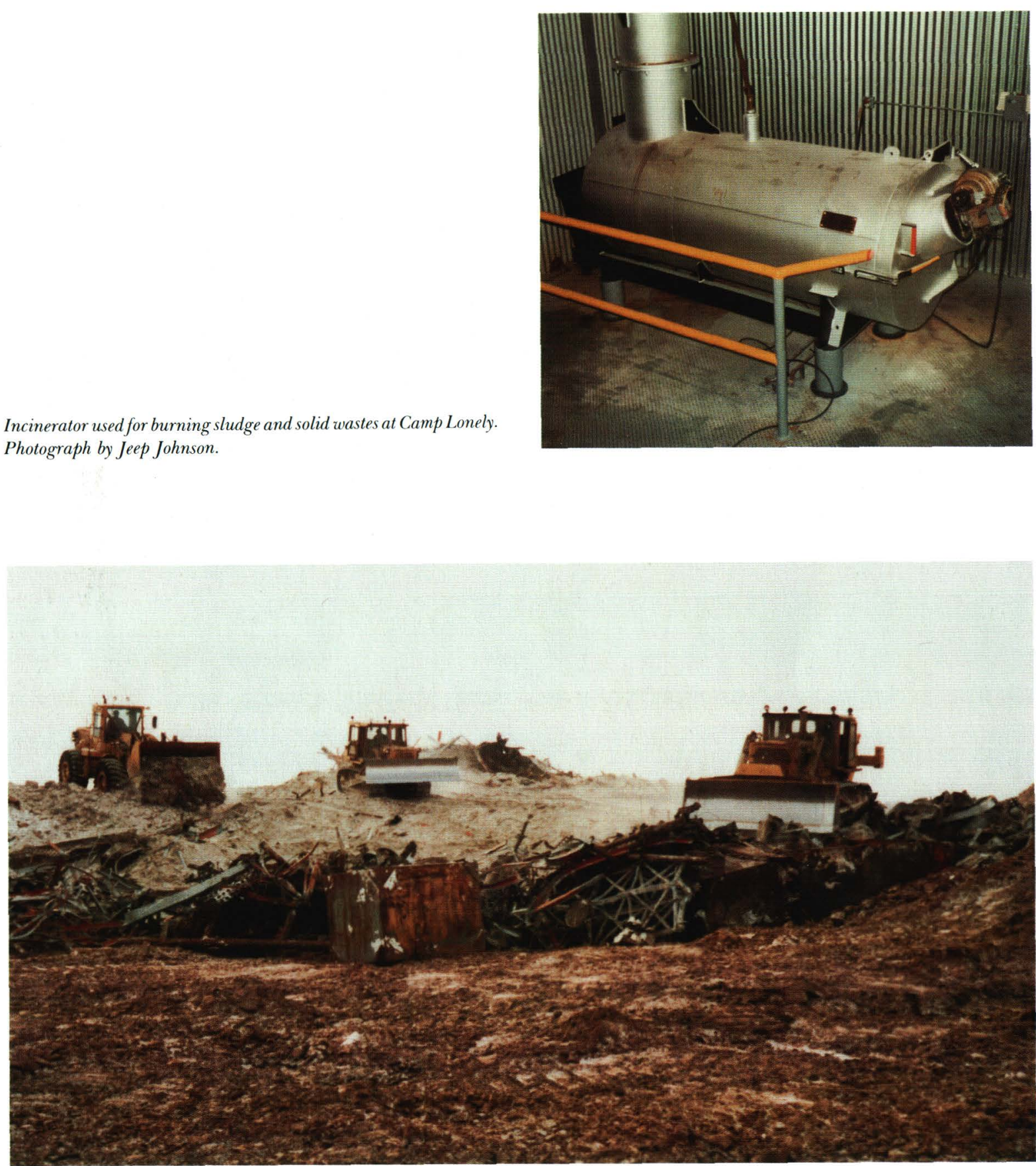

\section{Logistics}

The logistic problems attached to an exploration program of this size in the harsh, remote area of the NPRA were great and were complicated by the pervasive presence of permafrost on the environmentally sensitive Arctic Coastal Plain. An idea of the size of the task is illustrated by the volume of material that was moved each year. Every year that the USGS was in charge of the active exploration program (1977 through 1982), more than 50,000) tons of fuel, equipment, and supplies was transported to Camp Lonely, the "hub" of the exploration effort.

The distant-early-warning (DEW )-line site at Pitt Point, known as "Lonely," was chosen as the location for the central camp by the U.S. Navy before transfer of the exploration effort to the USGS. This location was picked because it had a 5,000-foot allseason gravel runway, some fuel tanks already in place, a good beach for unloading barges, and a large unoccupied gravel pad, and it was centrally located for the Navy's exploration plan.

Lonely was a large camp. It was home for about 100 men and women during the busy winter drilling seasons. They lived comfortably, with heat, light, and power supplied by generators. They had hot meals, warm beds, hot showers, flush toilets, and good recreation and exercise facilities. Camp Lonely was equipped with water- and sewage-treatment plants, and an incinerator for burning sludge and solid wastes. The camp was operated with the supervision and approval of the State

Some nonburnable wastes that were not removed by barge were buried

in landfill sites similar to this one. Photograph by John Schindler. 
The drilling camps were smaller versions of Camp Lonely. Locating a water source was the first job of the drillsite-construction crews. Then, smallscale waste-treatment systems were set up. Burn baskets were used to burn wood and paper products. Metals and nonburnables were hauled from the drillsite to Camp Lonely or to one of several approved burial sites in the NPRA. Drilling muds was contained in reserve pits.

Construction and seismic camps were mobile facilities, and their utilities differed slightly. Drinking water came from melting snow when lakes were unavailable. Wastes were either incinerated or hauled to Camp Lonely or a drillsite. The State permitted these small mobile camps to dispose of small volumes of oil and other burnables by open burning.

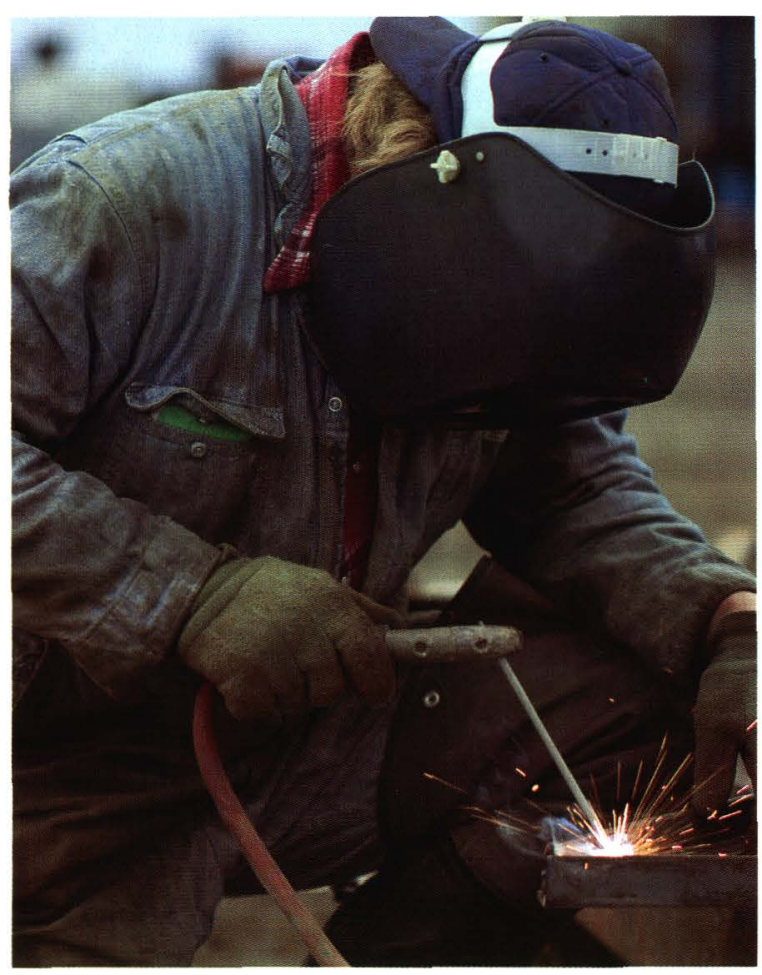

Welder at Camp Lonely. Photograph by Jeep Johnson.
Camp Lonely was also needed to stockpile drilling supplies. Almost all the wells drilled were far from any previous drilling, and little was known about the subsurface conditions. Detailed drilling plans were made before drilling each well-plans based on the best geologic knowledge obtainable. However, subsurface conditions seldom were precisely as predicted, and the amounts of casing, cement, mud, bits, fuel, and myriad other necessities were either overestimated or underestimated, thus, a local stockpiling area was required. Unpredictable drilling conditions, such as overpressured zones and lost-circulation zones, could require extra amounts of drilling mud and additives, or even an unplanned string of casing. This unpredictability of wildcat exploration requires a nearby source of all kinds of drilling supplies.
Most of the annual 50,000 tons of cargo went to Camp Lonely, where it was inventoried and assigned to a well; then, it had to be transported to the well location and, if surplus, transported back to Camp Lonely and put into the inventory again. During the exploration program, more than 250,000 tons of materials was transported by aircraft alone!

The bulk of the material transported from the "Lower 48" to the NPRA came by barge once a year. The ice generally opens and retreats from the beaches long enough in early August to allow barges to land and unload along the Alaska shore of the Arctic Ocean. If barges can get in, they are by far the cheapest method of shipping bulk cargo.

Some rigs drilled as many as three wells during the drilling season-a situation that required close

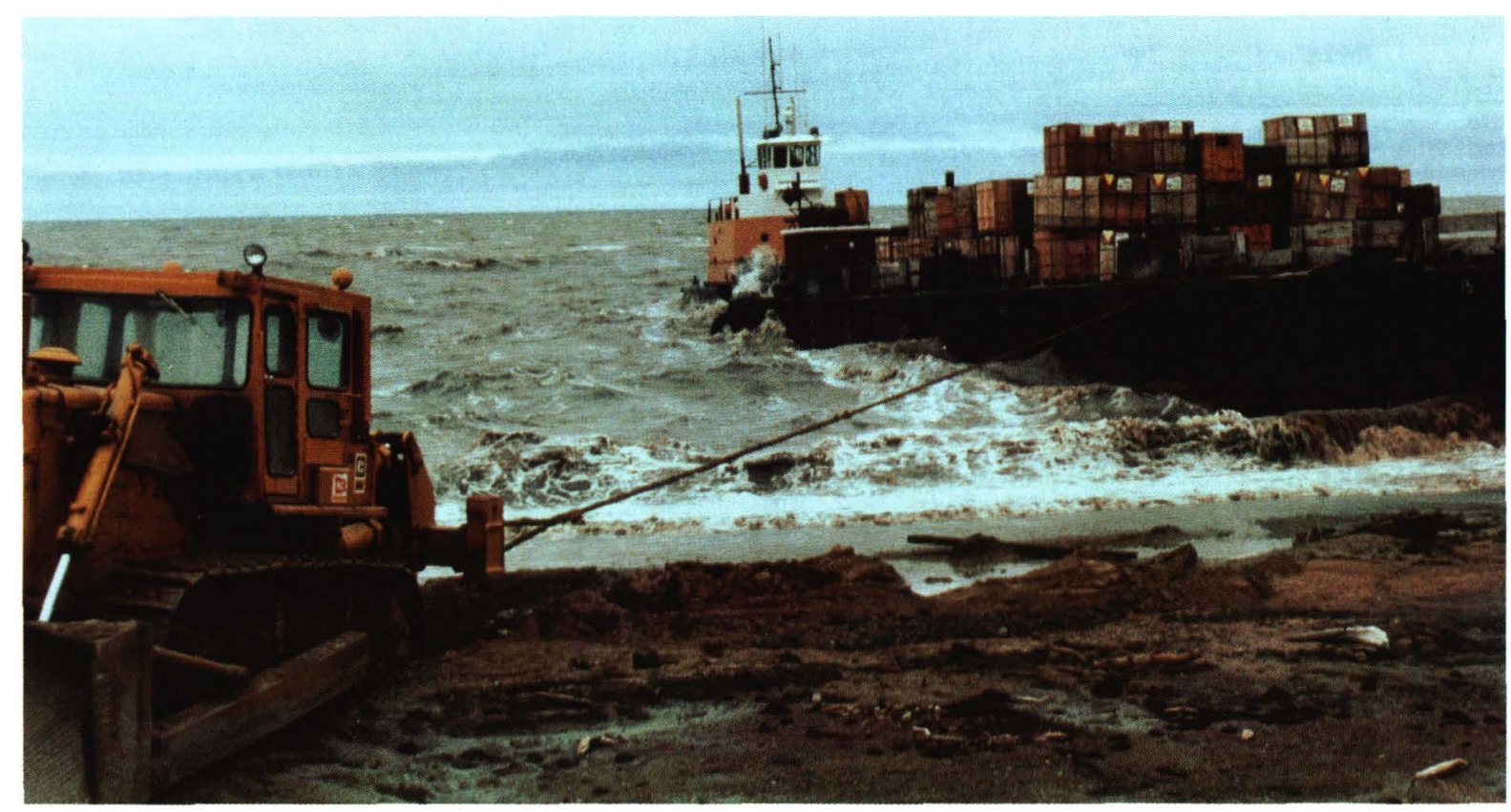

Landing barges on the coast near Camp Lonely. Shipping by barge is the most inexpensive method of transporting large amounts of material to the Arctic coast but is generally restricted to a short period in August when the ice retreats from the shorelines. Photograph by $S$. Krogstad. 


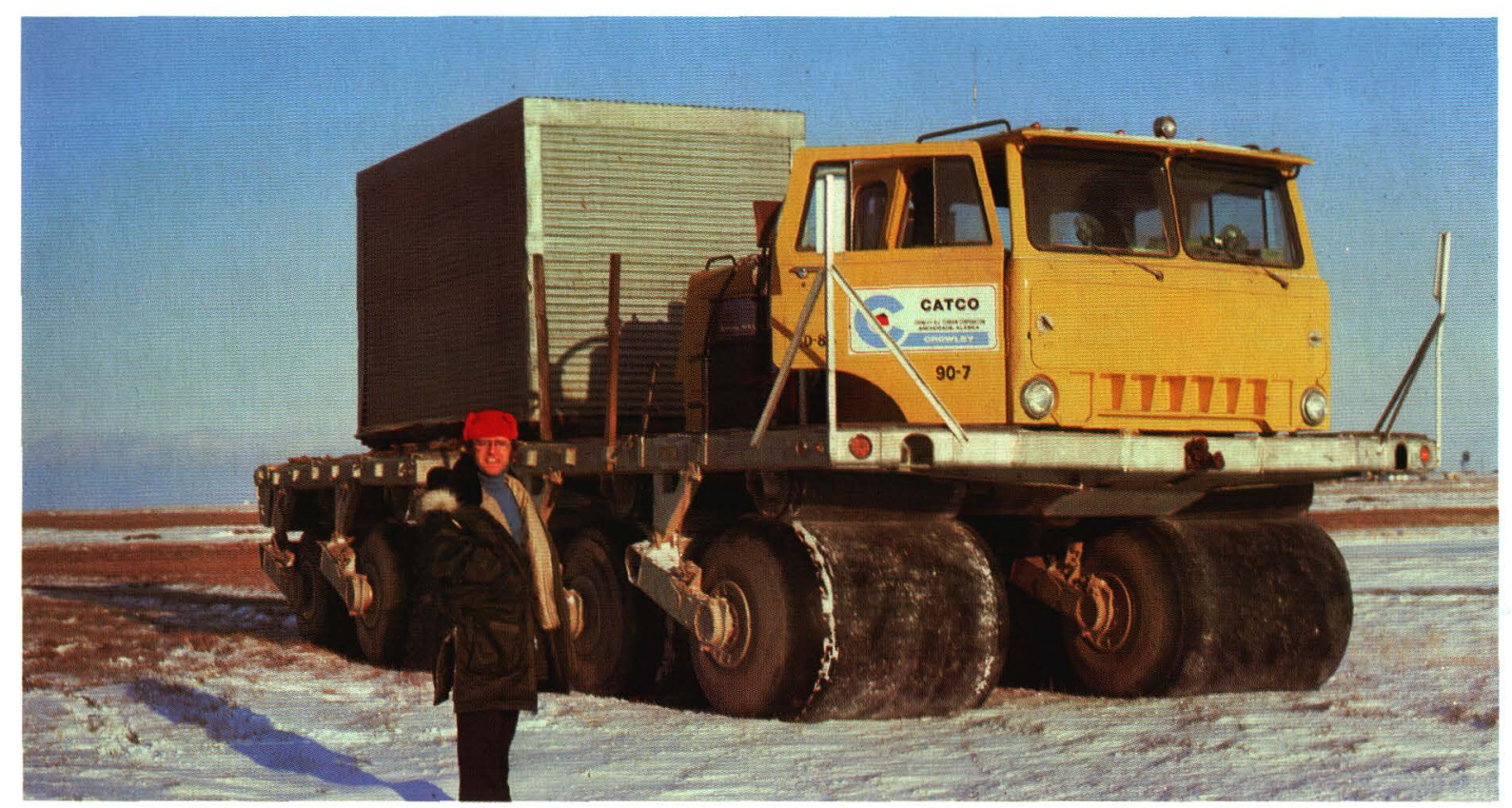

CATCO Rolligon. Huge balloonlike tires exert only 4 to 5 pounds per square inch when carrying as much as 80,000 pounds across the frozen tundra. Photograph by Jeep Johnson.

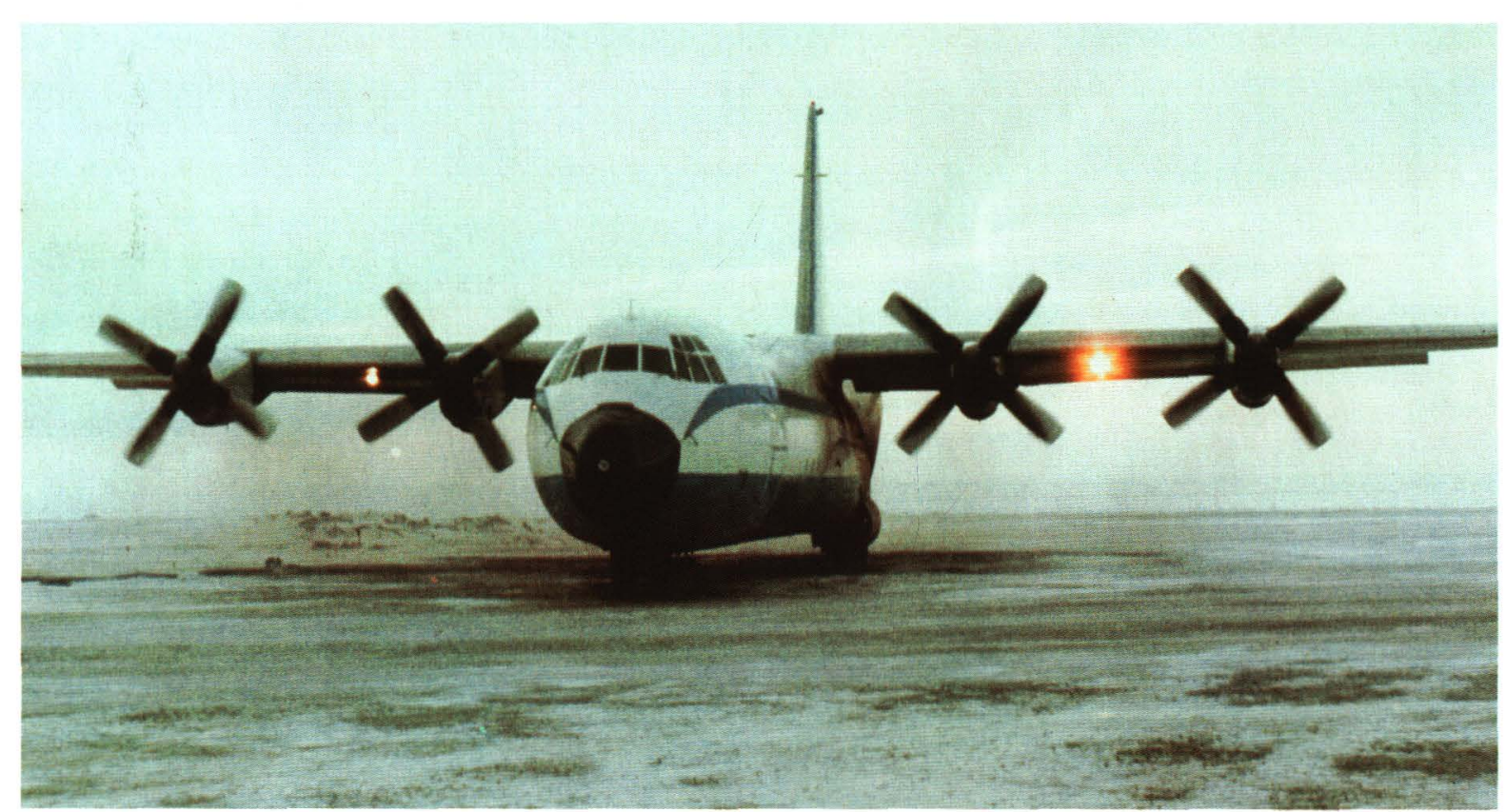

scheduling and precise planning. Rigs were not moved during the summer, when the tundra was soft. Most rigs were moved with a combination of large C-130 Hercules aircraft with all-terrain vehicle (ATV) support. The primary vehicles used were CATCO Rolligons - a very large tractor-trailer combination mounted on huge, low-pressure, balloonlike tires. These vehicles could carry an 80,000-pound load while exerting only 4 to 5 pounds per square inch on the frozen tundra-less than the average human foot pressure. Each well drilled required that the drill rig, along with the proper amounts of casing, cement, mud, fuel, bits, and so on, be moved to the location. It has been estimated that about 10,000 tons was transported to the average location and that the typical rig move was about 50 miles. These figures translate into approximately half a million ton-miles per location.

This huge logistic task was coordinated through Camp Lonely, where the all-season airstrip was expanded, full communication networks were installed, and a large-capacity fuel-storage facility was constructed.

\section{Airstrips}

Both ice and gravel airstrips were used in the 1977-82 NPRA program. The advantage of airstrips and roads made of ice is that they are not permanent and thus more acceptable environmentally, and are less expensive. Lakes can also be used to an advantage for airstrips for aircraft up to $\mathrm{C}-\mathbf{1 3 0}$ Hercules and Boeing 737 size. For lake or sea-ice airstrips, snow is cleared from the ice surface and then grooved to increase traction. Lake ice must be 4 feet thick for full-load operations ( $41 / 2$ feet for brackish water). In contrast, airstrips on tundra require 1 foot of ice above the frozen ground.

Hercules C-130's (Hercs) provided contractors with the high-volume, high-tonnage capability necessary to transport drilling and construction equipment to the reserve. Photograph by Edmund Grant. 
The construction and drilling season normally was limited to the time between winter freeze and spring thaw. Overland travel was not allowed until the surface was frozen to a depth of 12 inches and the average snow cover was 6 inches thick. These regulations restricted the winter working season to about 170 days. Most ontundra ice airstrips could be operational more quickly than lake strips; the time saved might allow a well to be completed in one season instead of two. The necessary requirements for building such an airstrip are a water source nearby and a large flat open area, as much as 6,000 feet long, on which not less than 12 inches of water can be layered and frozen. Vehicles carrying insulated water containers are used to spread the water in thin sheets. The water is spread at a rate that allows complete saturation of the surficial snow and tundra before freezing. Pumping systems using insulated pipes were used to flood some airstrips to hasten thickening of the ice. Using either method, the average ontundra ice airstrip required $7.4 \mathrm{mil}-$ lion gallons of water (excluding any required maintenance of the strip) and was built in a few days. An airstrip of this type causes little damage to the tundra but has only a one-season lifespan.
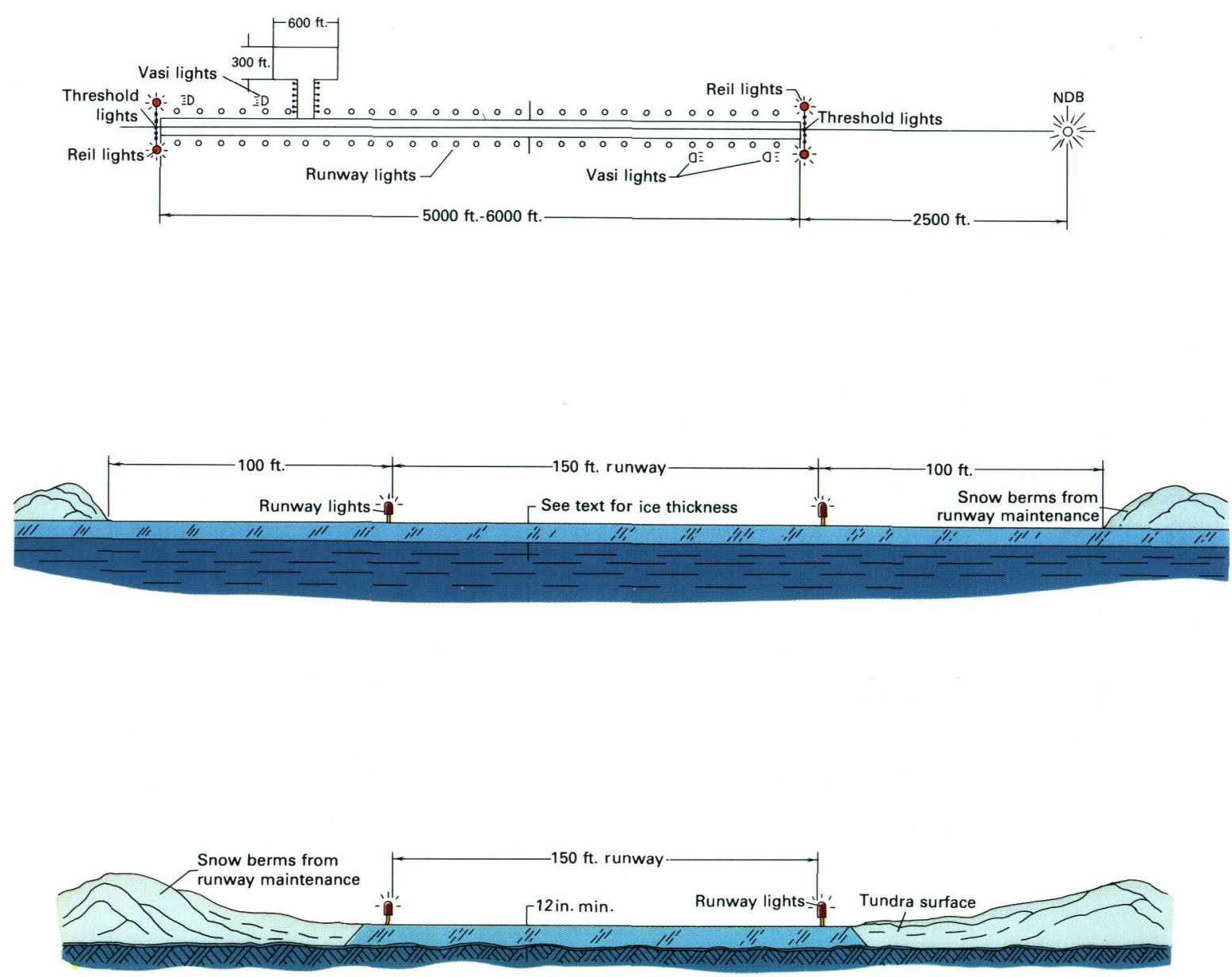

Winter airstrips were constructed on lakes, sea ice, and tundra. Lake ice must be 48 inches thick, and brackish ice 54 inches thick. In addition, to prevent tundra damage, a minimum of 12 inches of ice was required on top of the frozen tundra (modified from Mitchell, 1983). 


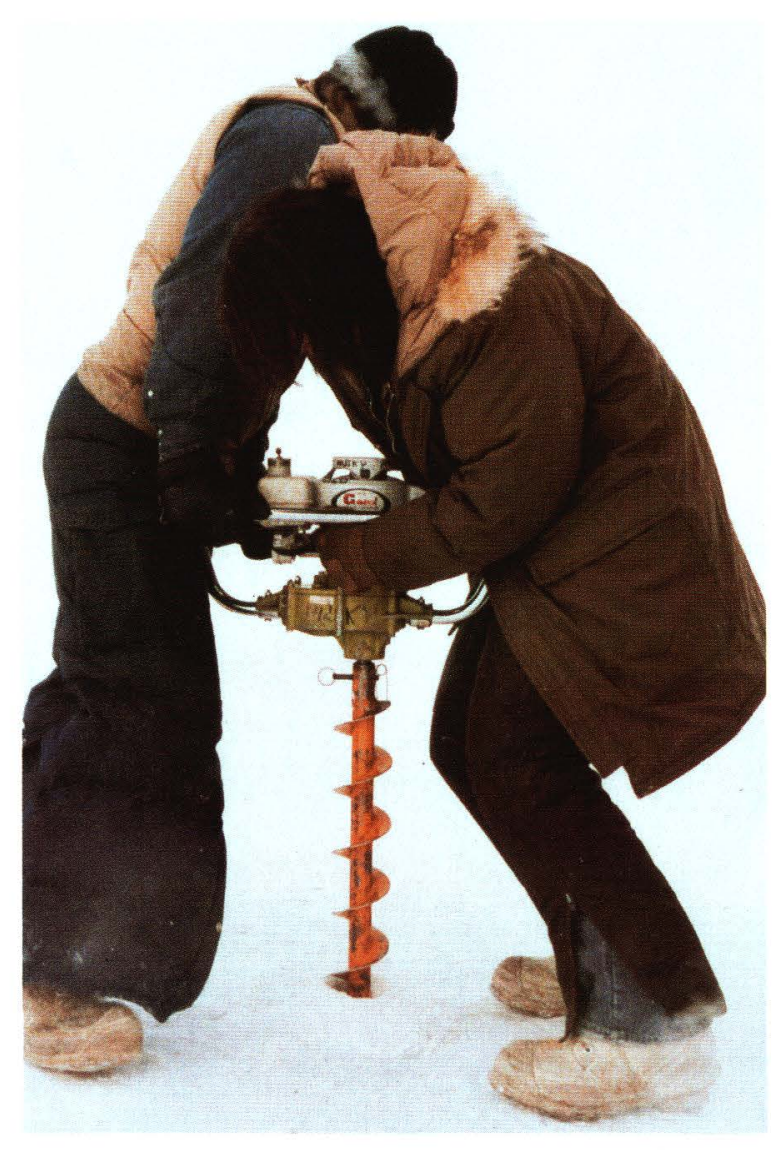

Workers test the thickness of lake ice. Photograph by Jeep Johnson.

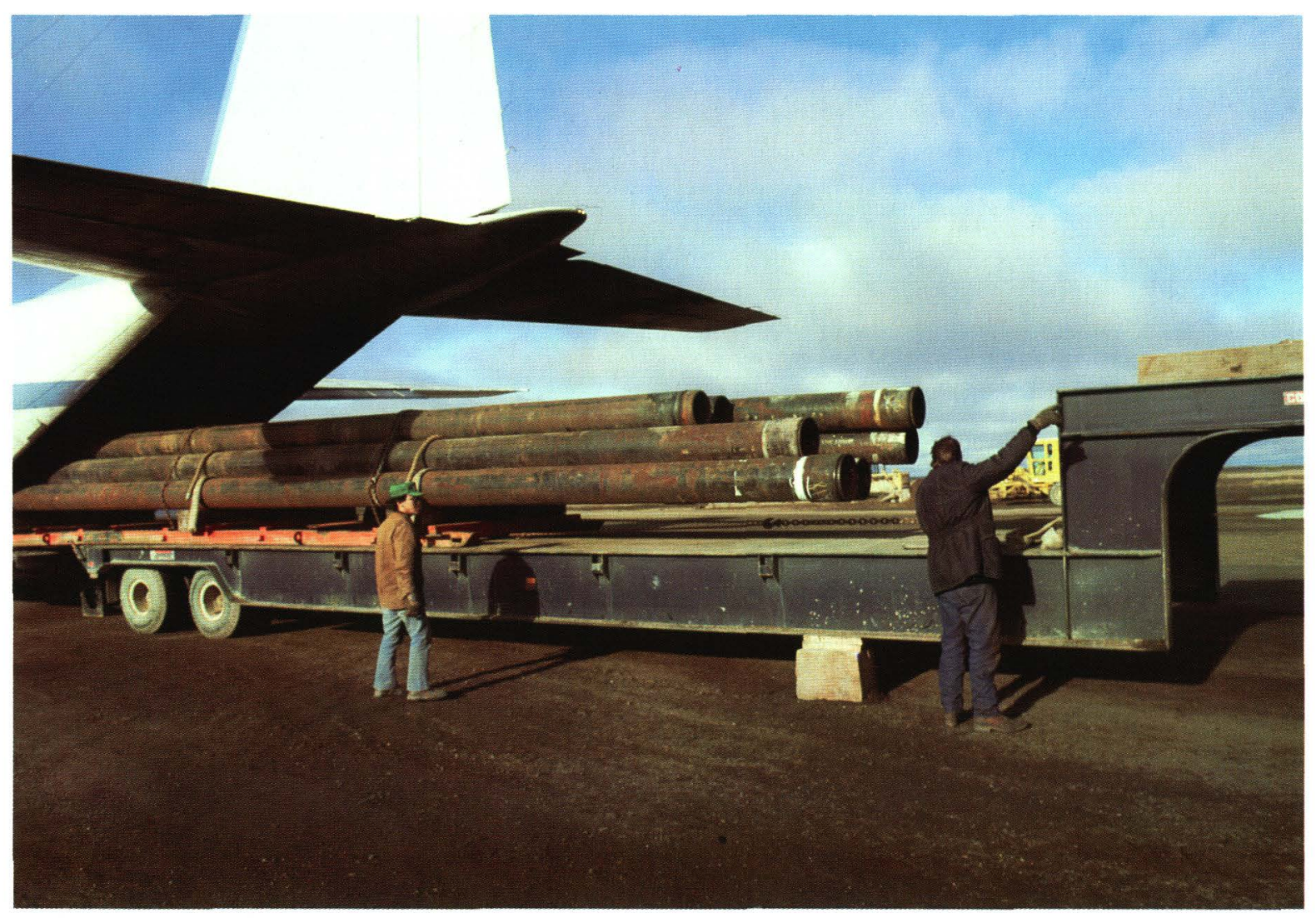

Unloading drill pipe from a Hercules at the Camp Lonely airport. Photograph by Jeep Johnson. 


\section{Ice roads}

Ice roads were used at most locations for routes between the drillsites and airstrips, borrow pits, and water sources. Snow is compacted over the frozen ground and repeatedly flooded with water to build up ice layers. Roads carrying heavy traffic and heavy loads required thicker ice and more maintenance than those made for less traffic and lighter loads. A 37-mile-long road, the longest in the NPRA, from the Kikiakrorak River delta to the Inigok allseason airstrip, was used to transport 90,000 cubic yards (about 6,000 truckloads) of gravel to build the Inigok drill pad and airstrip. The route took advantage of every lake, pond, and river along the way. A total of 35 million gallons of water was required to form the ice road.

At the Inigok and a few other drillsites, it was essential that the airstrips remain operational throughout the summer, so that the drilling could continue without interruption. The Inigok well needed an estimated 330 drilling days to reach a total depth of 20,000 feet. If drilling had taken place only during the winters, three seasons would have been required-involving twice breaking camp, three times setting up camp, costly idle time for the drill rig between winters, and added risk associated with reentering the drill hole each new drilling season. Despite the environmental and economic drawbacks to gravel-road construction, the lower price and lower risk associated with year-round drilling made it worth the cost.

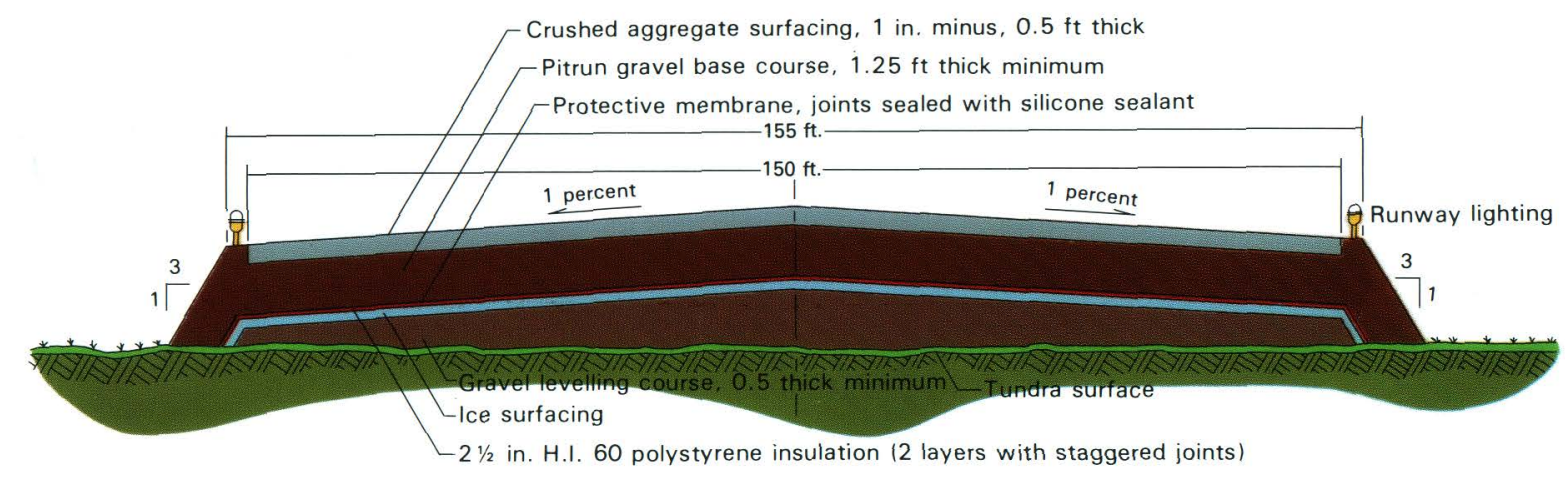

Cross section of a typical all-season airstrip. Gravel airstrips were more expensive to construct but could be used year-round (from Mitchell, 1983). 


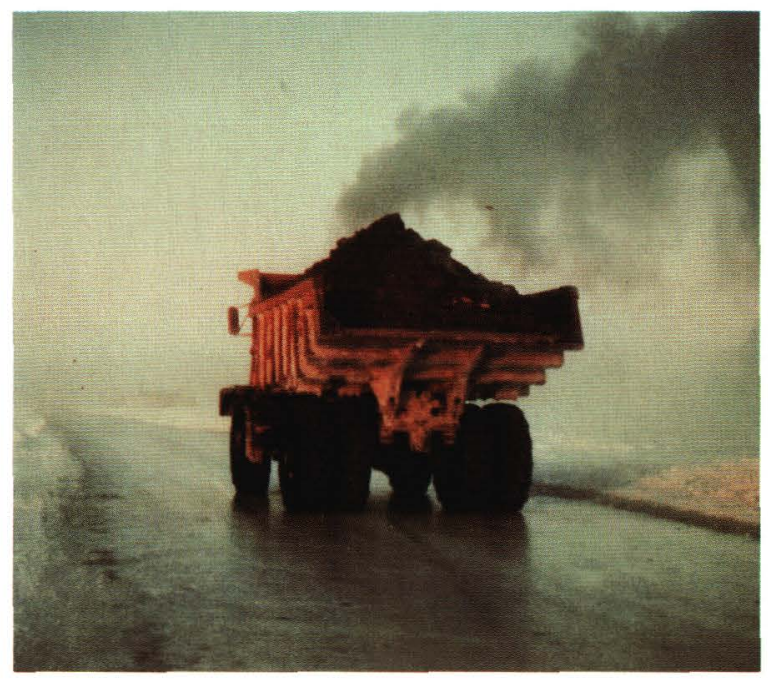

Gravel hauled along the ice road at South Simpson. Photograph by John Schindler.

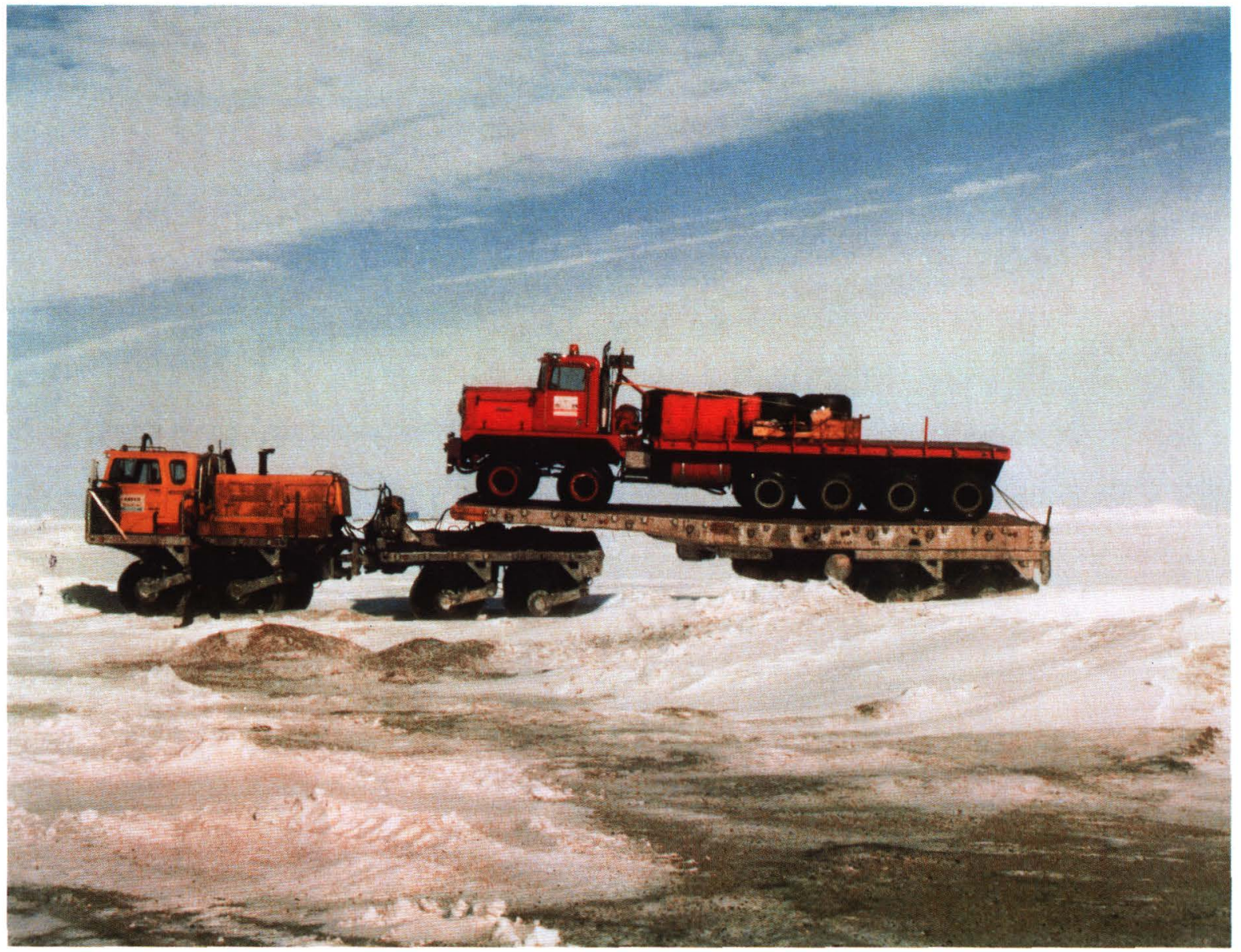

Large trailers used wide balloon tires for transporting heavy equipment across the tundra. Photograph by Jeep Johnson. 


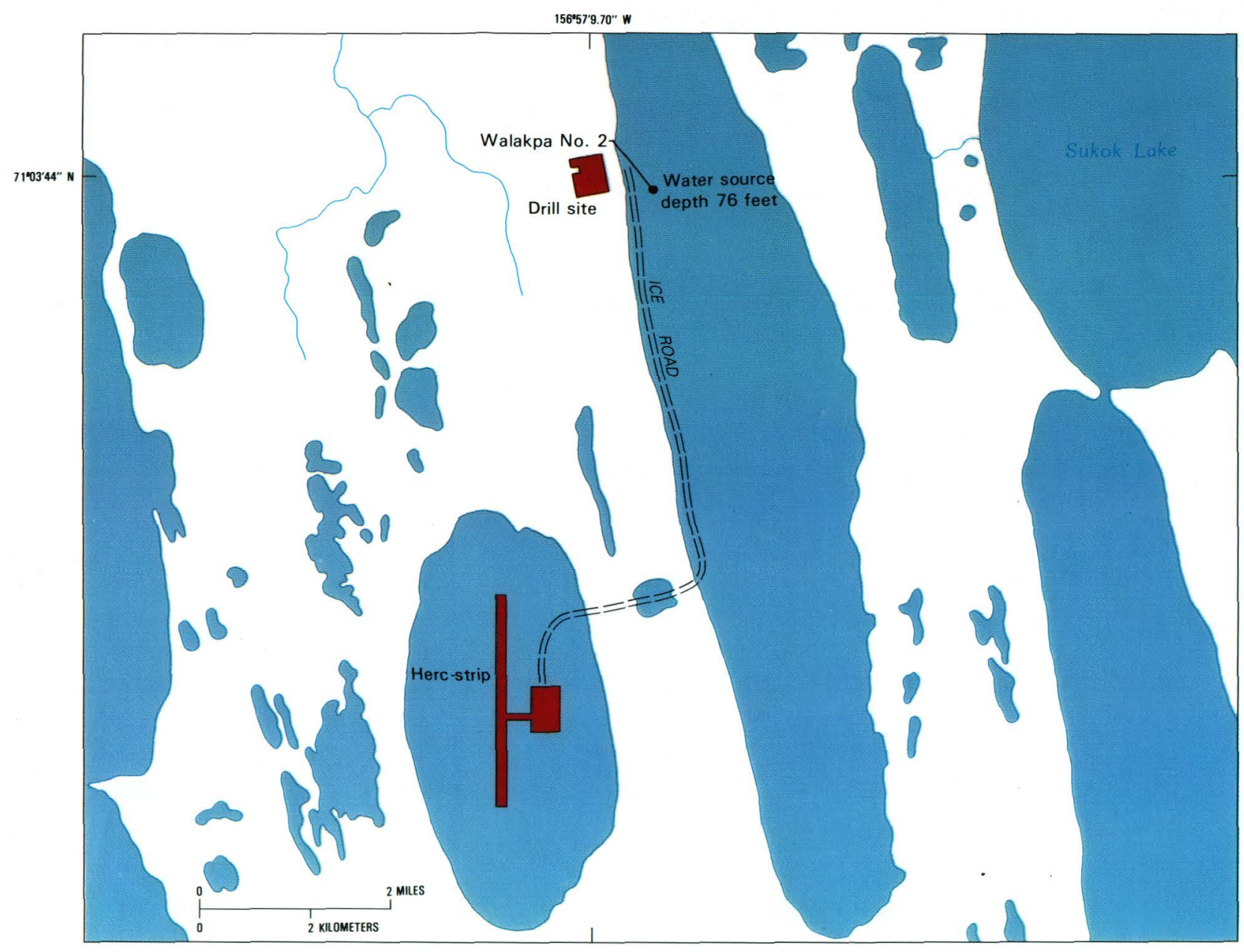

Example of a carefully planned, environmentally sensitive transportation route at the Walakpa No. 2 test well. Instead of a straight road

connecting the well to the airstrip, the chosen route avoided the tundra surface as much as possible by taking advantage of every lake, pond, and river along the way. 


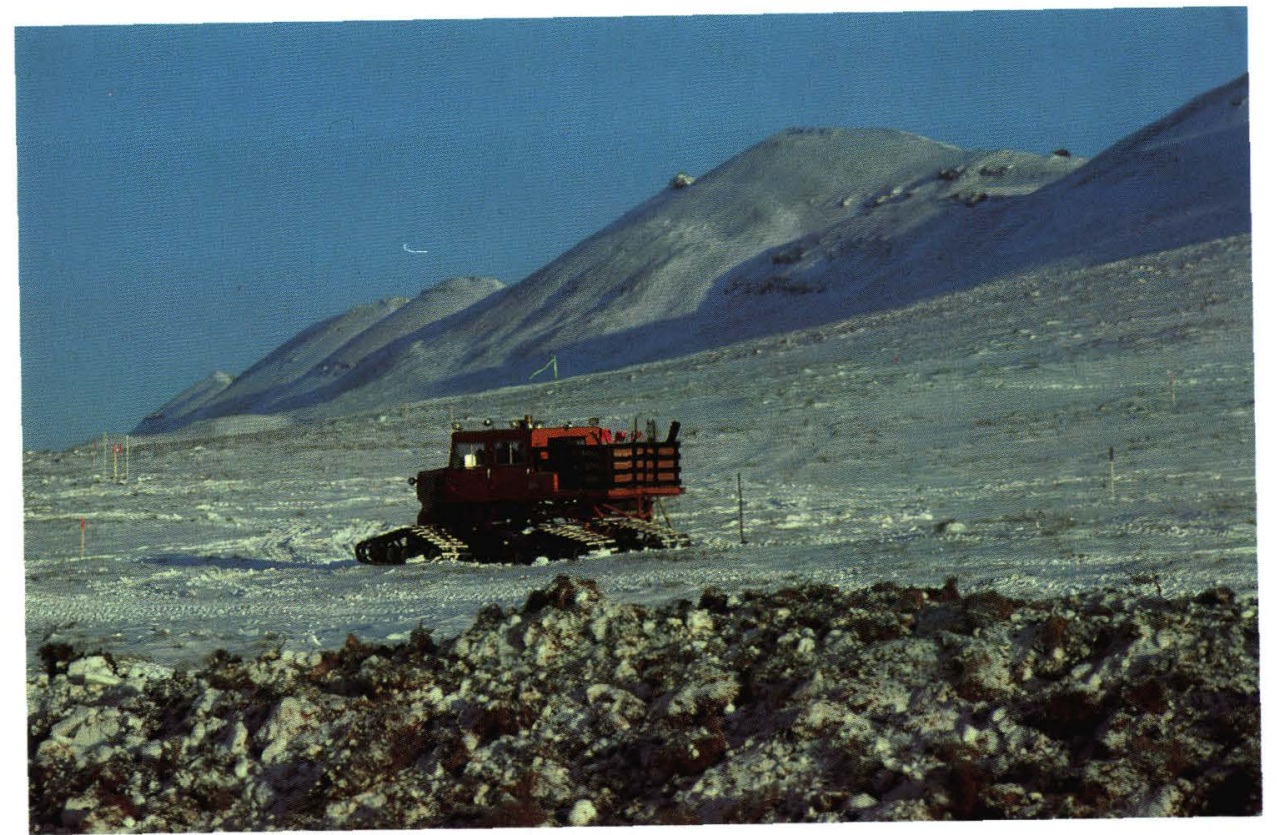

Scouting the Lisburne wellsite. Drill-pad location is "staked out" in background. Photograph by Jeep Johnson.

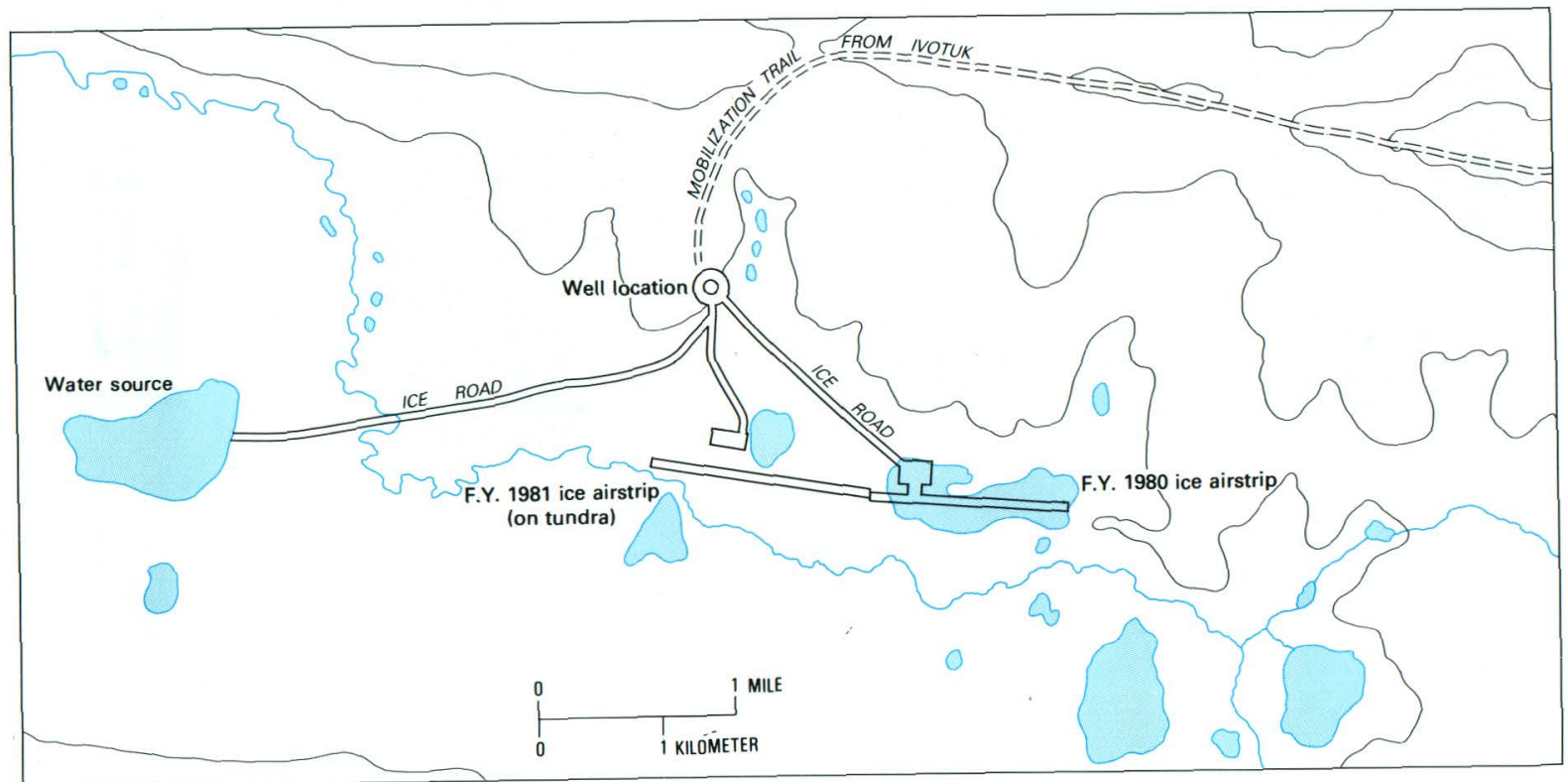

Two-season drillsite layout for the Awuna No. 1 test well (from Mitchell, 1983).

\section{Drillsite construction}

Design of drill pads evolved during the period when the USGS conducted the exploration program. While the U.S. Navy was in charge of the program and shortly after the USGS took over, a design was used that had been developed at the Prudhoe Bay oil field. The pad was constructed of thaw-stable gravel, not less than 5 feet thick. This design became known as the "thick pad" and was used by the USGS for only its first drilling season.

Most of the wells drilled by the USGS to help evaluate the petroleum potential of the NPRA were to depths that could be reached in one winter season. The Naval Petroleum Reserves Production Act of 1976 (Public Law 94-258) specifically prohibited development and production of hydrocarbons, and an all-season work surface was not needed for exploration and testing. As mentioned above, gravel, plentiful in the Prudhoe Bay area, is extremely scarce in the NPRA. Therefore, a "thin pad" concept was developed.

A few wells were too deep to complete in one winter season. For these wells, all-season pads and airstrips were designed that allowed year-round operation of the drill rig and provided the required facilities and support to keep the operation running throughout the summer thaw. All wells drilled on the NPRA during the more recent program used one or another of these three designs.

\section{One-season drill pads}

The design of the pad was selected after the well location, target depth, and type and size of drill rig had been agreed upon. The site was surveyed, and lakes were examined and sounded for water supplies, as well as for suitability of use as an ice airstrip. In addition, environmental studies were conducted, including fisheries and wildlife. The areas were also checked to ensure that no archeologic sites would be disturbed. The route of the construction train to the site was carefully chosen and marked, so that it could be followed easily even when visibility was severely reduced. 


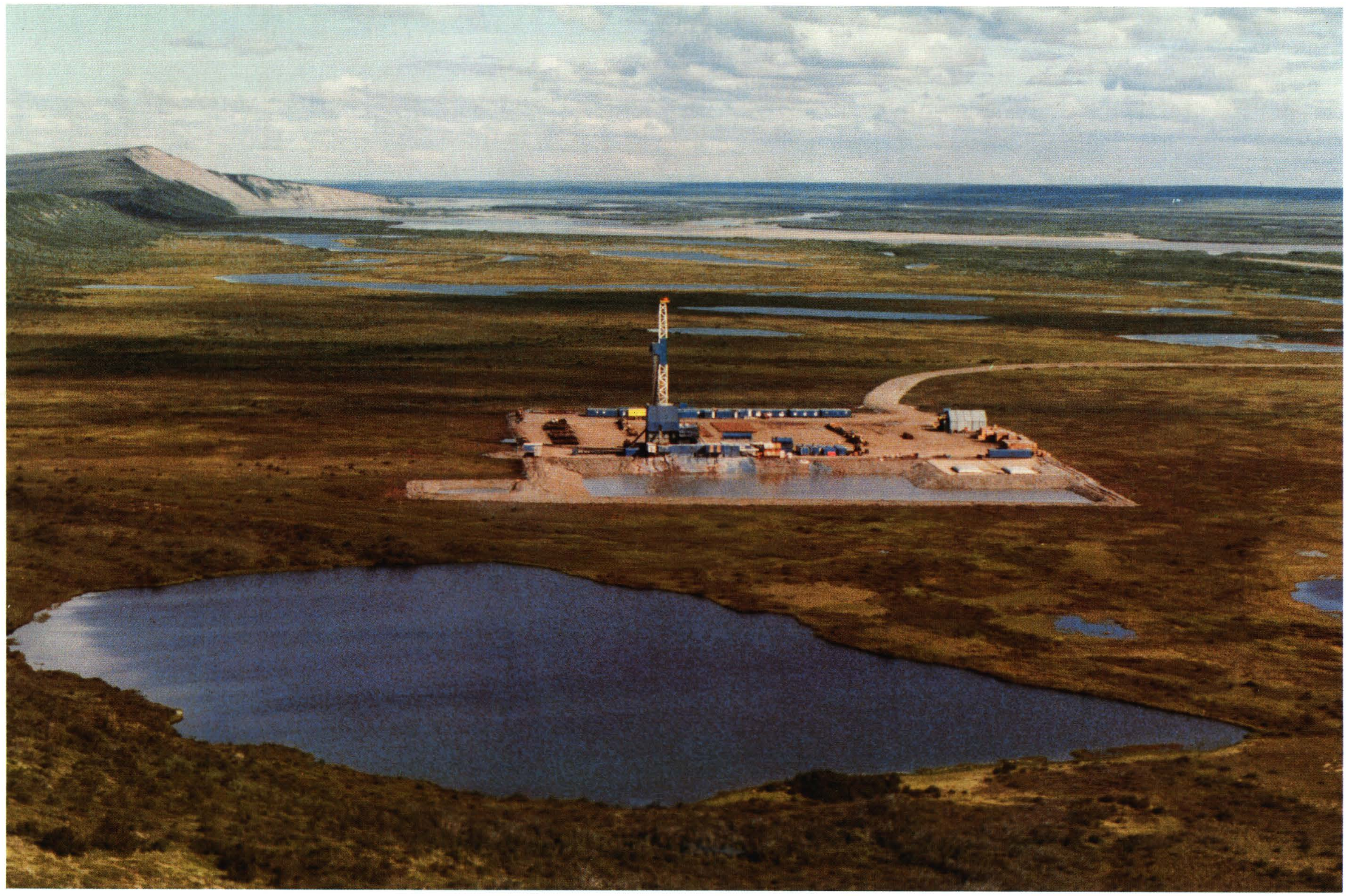

Drilling the Seabee No. 1 test well near Umiat on the Colville River.

Photograph by John Haugh. 


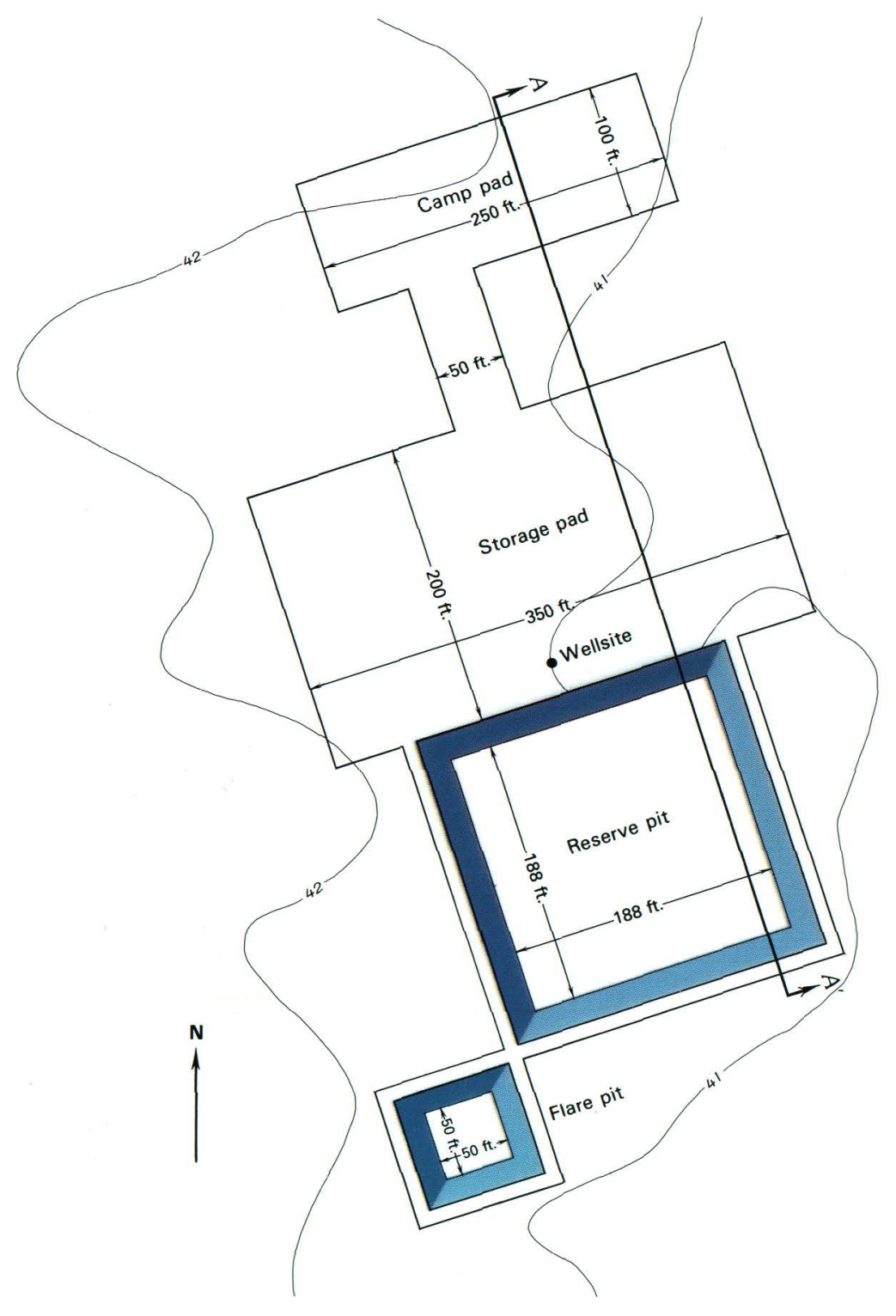

PLAN VIEW
Plan view of a one-season, thin-pad design. For safety reasons, the wellbore, the flare pit, the pad used for bulk fuel storage, and the drilling camp on one-season drill pads were separated by at least 300 feet (modified from Mitchell, 1983).

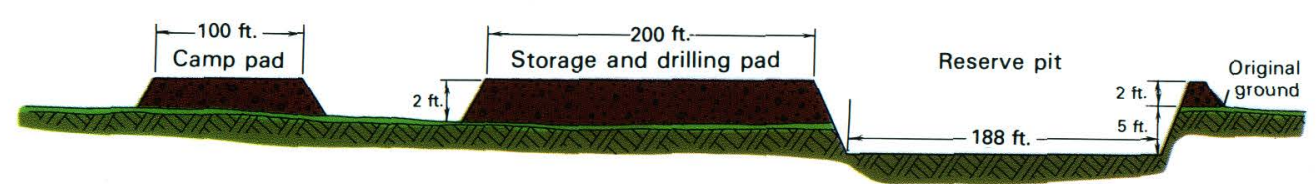

SECTION $A-A^{\prime}$ 
If the thick-pad design was selected, the drill rig was located adjacent to the reserve pit, and the fuelstorage and camp areas were set back from the rig for safety. The pad area around the rig was used for storing drill pipe, chemicals, and mud. The reserve pit was large enough to hold all the spent drilling fluids. A flare pit was used when well fluids recovered during testing needed to be burned off. The pad was elevated about 5 feet above the ground surface and consisted of sufficient fill to prevent the summer thaw from reaching the original tundra. Thus, the subsurface beneath the drilling operation remained frozen.

As the exploration program continued, the thickpad design was modified to suit the conditions in the NPRA. Because most of the drilling was planned for the winter season, this design was modified to a two-layer pad to conserve the scarce gravel. The lower layer contained ice-rich material excavated from the reserve pit, and the upper layer was of relatively thaw stable material from a borrow site. Settling of the pad was expected when the ice-rich lower layer thawed. Such thawing was caused both by heat resulting from the drilling operation and by the summer melt. The drilling operation generates heat, and warm fluids are circulated in the hole, so that thawing occurs beneath the drill rig even in winter.

To avoid settling of the drill structure, NPRA rigs were supported by pilings extending into the ground well below the expected thaw level. From 50 to 210 pilings were required, depending on the size of the rig. These pilings were set between 14 and 25 feet below the surface, the deeper pilings were placed under the subbase and derrick areas. To set the pile, a 2-foot-diameter hole was augered, the pile put in place, and the hole filled with a slurry of water and soil that froze the piling in place. Thus, the drill rig was supported by pilings and not by the pad.

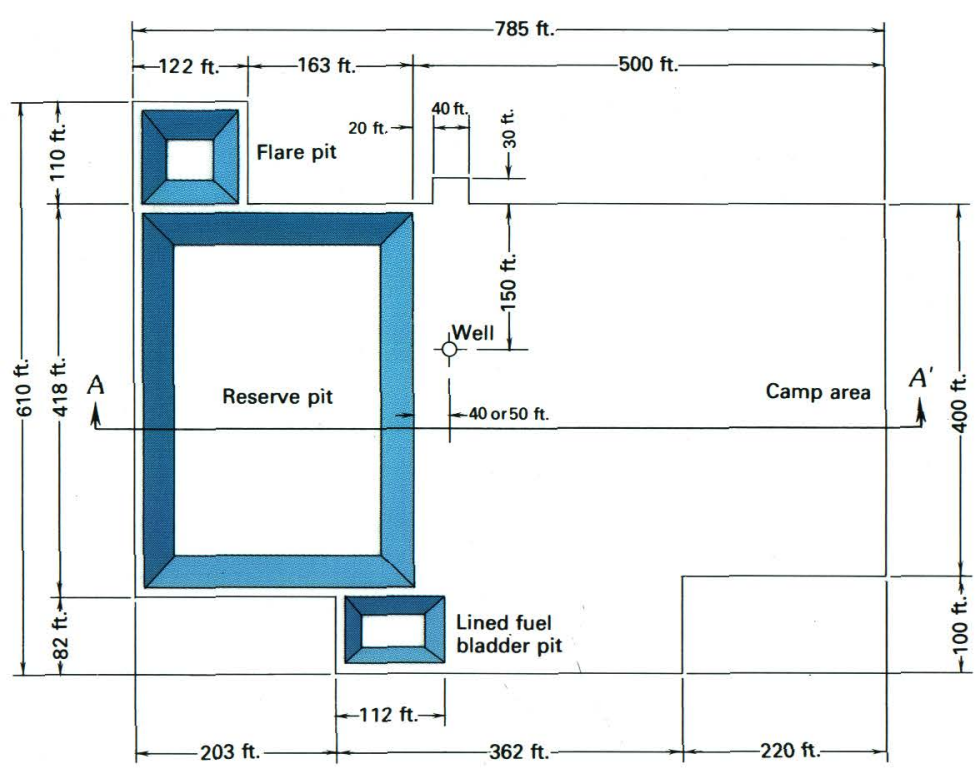

PLAN VIEW

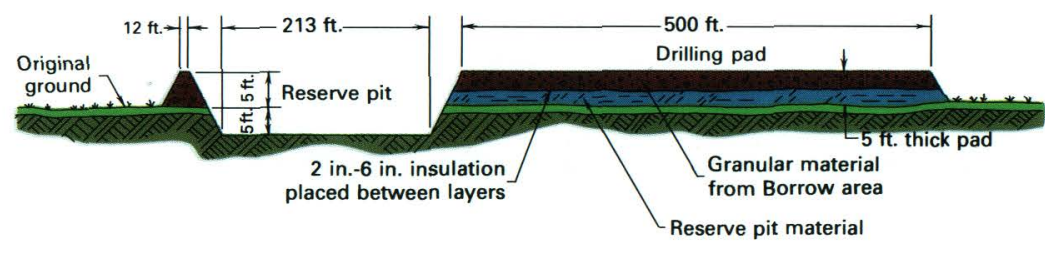

SECTION $A-A^{\prime}$

Plan view and cross section of a year-round or all-season drill pad. These pads were modified from the old design by adding a layer of synthetic insulation between the lower, ice-rich layer and the thawstable gravel surface (from Mitchell, 1983). 


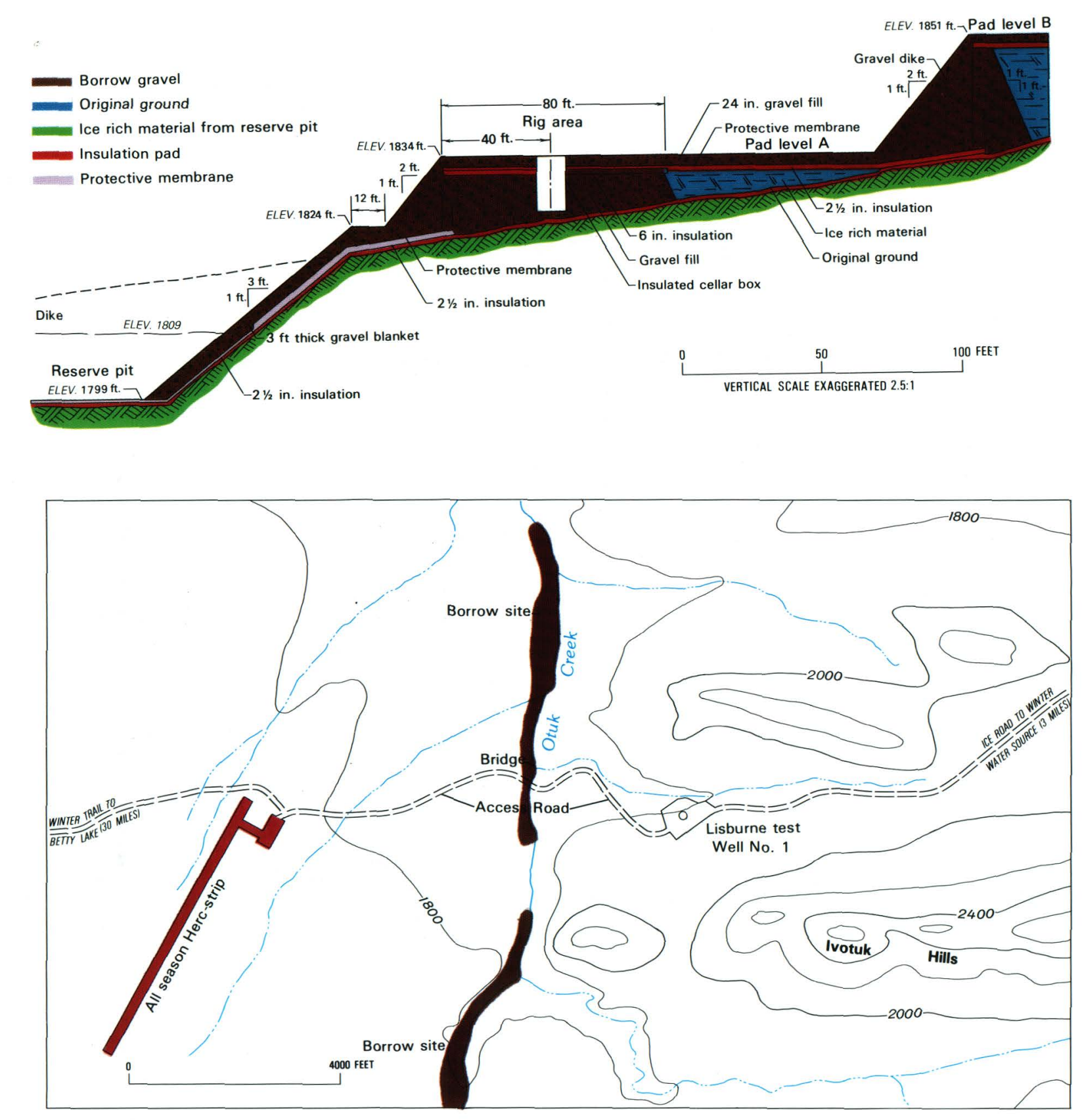

Cross section of the Lisburne drill pad, an all-season thick pad (from Mitchell, 1983).

Layout of the Lisburne drillsite (from Hewitt, 1983). 
Soil conditions varied considerably in the NPRA, but, in general, they were unfavorable for drill-pad construction. Most drill pads were located on icerich mud or silt. These materials were excavated from the reserve pit and used as the lower layer of the pad. The upper layer was constructed of fine sand that was found in dune areas or in banks along the rivers or lakes.

The normal time to construct a thick drill pad was about 30 days. Construction usually started in November or December, to allow enough time for the drill rig to be moved to the location, the well to be drilled, and the rig removed before the thaw in mid-May. The drilling camp, fuel, and equipment were usually stacked on timbers and left until the following winter's ice road and ice airstrip were again usable.

The thick-pad design was abandoned after the 1977-78 season because of experience gained at the South Meade site. This test well was located in a swampy area, and the original design called for a borrow site about half a mile away. To save costs and with the geologist's approval, the drillsite was moved to the borrow site. The reserve-pit excavation produced sufficient material for a thin ice-rich pad, assuming a one-winter operation. This procedure eliminated hauling from a borrow site and building an ice road between the pad and borrow site, and thus reduced costs. It also reduced the environmental impact. The experiment was a suc cess, and the South Meade site was used for a sec ond season with only minor repairs.

The thin-pad design provided a pad thickness of about 2 feet and allowed the pilings to be cut off above the original surface. The elevated pad also kept the drill rig relatively free of snow. The 12 thin pads constructed were totally satisfactory.

The thin-pad concept had several advantages. The pads were less costly to construct than the thick or all-season pads. The need for borrow mate- rial, its removal, and hauling was not required. Fewer men, less time, and less equipment were needed to complete the preparation of a drillsite. Construction and maintenance of an ice road between the site and borrow pit were also unnecessary. Furthermore, shortened construction time meant that more days were available to drill the well.

The thin pads were also environmentally preferable. Thin pads reduced the area of disturbance by eliminating a borrow site and made rehabilitation and revegetation easier. Use of the thin-pad design eliminated the need to break up and spread the fill, because it was not thaw stable. During the summer after the drilling, the thickness of the pad was reduced about 50 percent or more by ice melt and settling. In addition, the fine-grained soils used in the thin pads were more suitable for revegetation than the gravel surfaces of the thick pads.

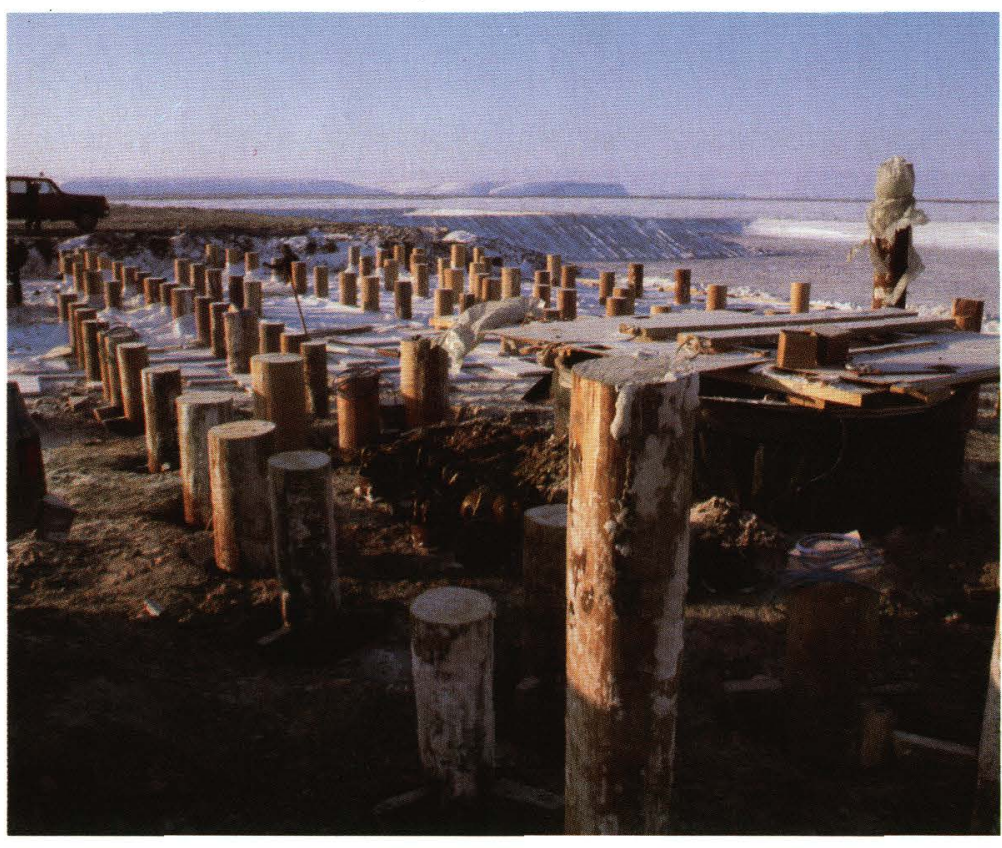

Construction of one-season thick pad at the Seabee wellsite. Photograph by Jeep Johnson.

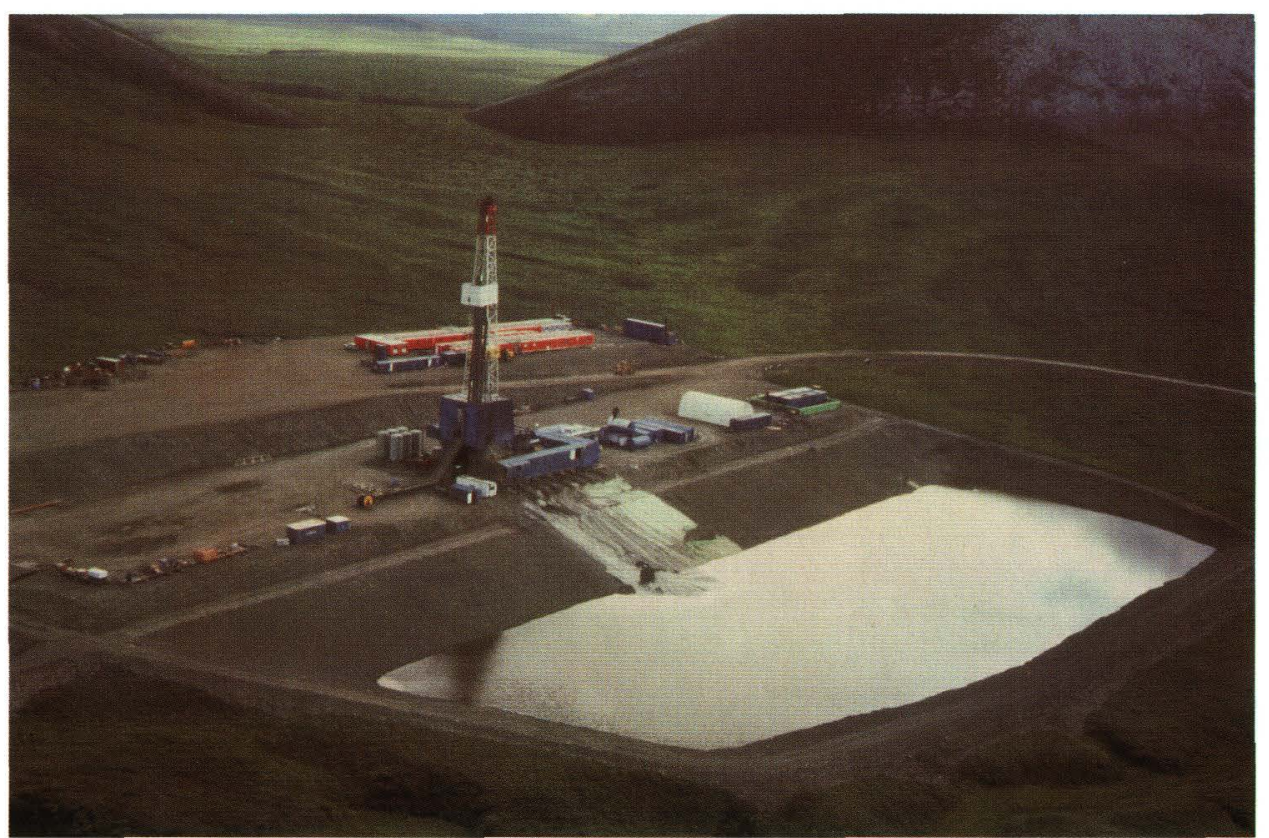

The Lisburne No. 1 test well was completed in summer 1979. Photograph by Jeep Johnson. 


\section{Year-round drill pads}

The exploration program called for a few 20,000 foot-deep wells, requiring an estimated 350 days of drilling, testing, and plugging. This work would have required three winter-drilling seasons, two pad reconstructions, and about 500 standby days when the drill rig was idle. A total of 900 days was estimated to be required. In contrast, an all-season program could be completed in only 520 days.

Another advantage of all-season drilling is the reduced risk. Risk is always associated with suspending and reentering a well. In permafrost areas, casing can collapse in inactive wells because of ground settling or freezing in the permafrost zone that blocks reentry
To prevent heat from penetrating the permafrost below an all-season drill pad, a very thick fill or an insulating layer within the pad was required. The NPRA all-season pads used Styrofoam for this insulation because gravel cost more, added to the environmental disturbance, and was scarce. The Inigok well is a good example of an all-season pad. The drill rig was supported by 218 timber piles slurried in place at depths of 25 to 45 feet, depending on the distance from the well. The piles closest to the wellbore needed to be set the deepest to withstand the most force from drilling and the heat generated by the drilling process.

Several other measures were taken to ensure that the drill rig would be adequate for a year-round period. Heavy steel beams spanned the deep-set center pilings, and 12 - by 12 -inch timber beams over the outlying pilings were used to distribute the load. A 6-inch-thick layer of insulation was applied to the outside of the conductor pipe to prevent heat flow from the well. Other heat sources were contained by a 6-inch-thick layer of Styrofoam under the drill rig, which was placed at an angle and covered with a plastic liner to direct the flow of liquids into the reserve pit. The upper layer of fill was gravel from a borrow site.

The NPRA exploration pad designs proved to be entirely satisfactory. The thin-pad design was the best choice for wells that could be completed within one winter season, and the all-season design was satisfactory for wells requiring several seasons to complete.

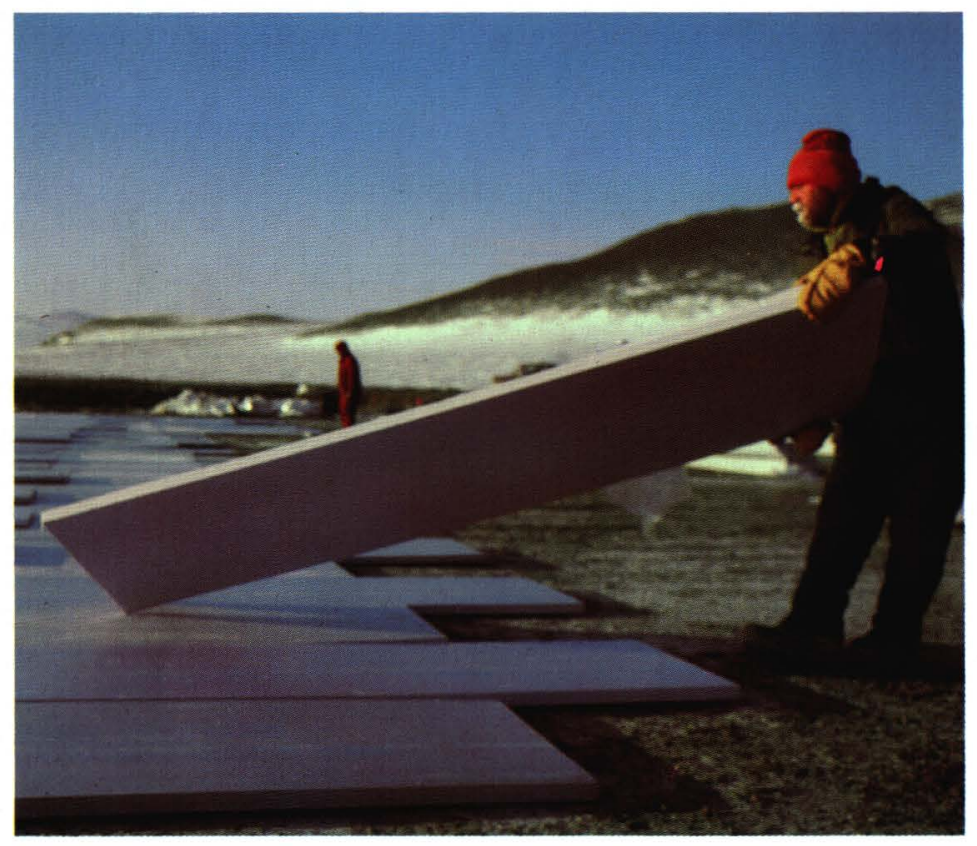

Six-inch-thick insulation protects the permafrost layer beneath the Lisburne drill pad. Photograph by Jeep Johnson.

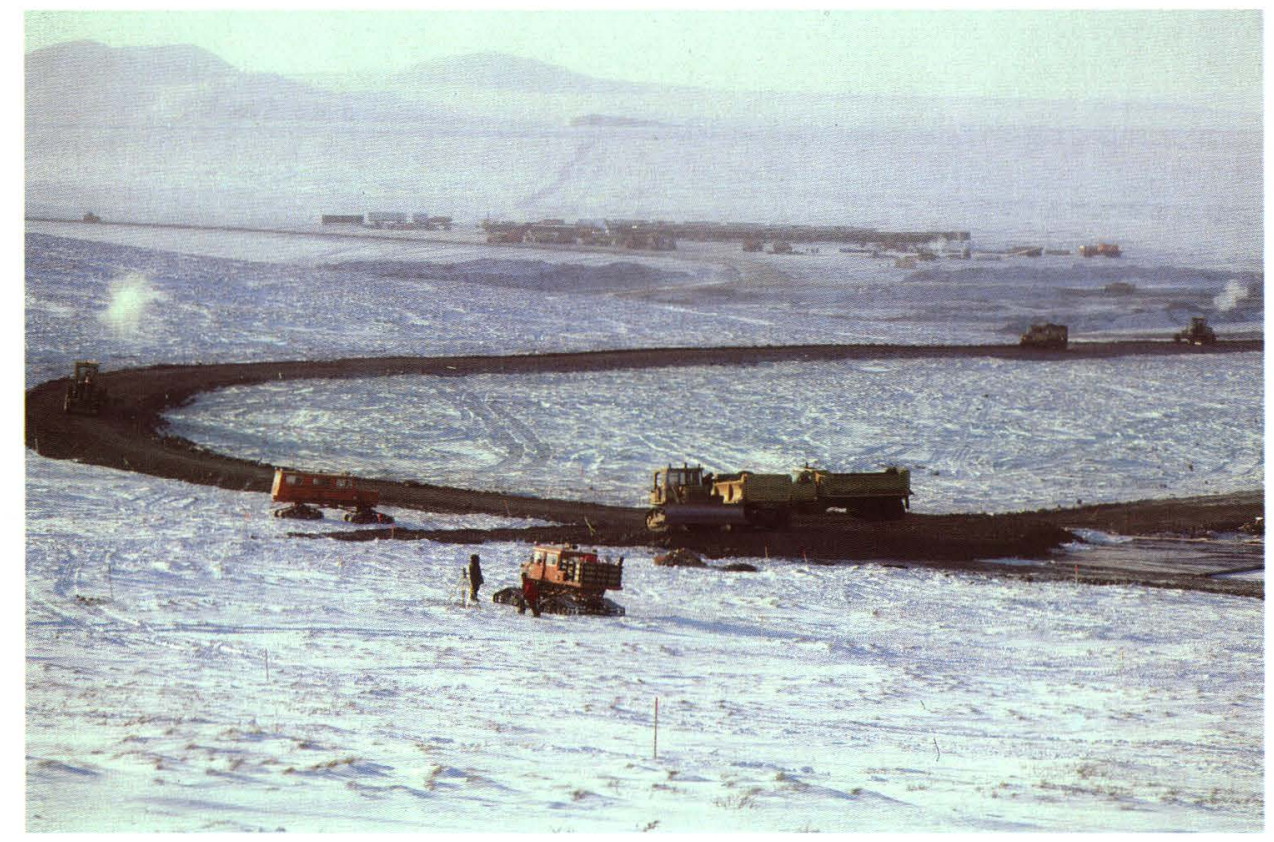

A gravel access road leads from the wellsite to the borrow site and allseason Herc airstrip. Photograph by Jeep Johnson. 


\section{How were cleanup and rehabilitation accomplished?}

Human concern with the deteriorating environment has reached even to the remote areas of Alaska. Pre-1960 construction and engineering activities in Arctic Alaska including the Pet-4 program of 1943-53, the construction of DEW-line stations, and other military and industrial activities, were all conducted without much consideration for possible environmental impacts. The main concern was getting the job done. Although the amount of debris and the extent of damage to the North Slope environment were small and localized, they were starkly visible on the flat and otherwise featureless Arctic plain. Sites along the coast, including Barrow, had large accumulations of abandoned or surplus materials.
Responding to growing criticism, the U.S. Navy, as NPR-4 managers, began a cleanup program in 1971 that was continued by the USGS. The cleanup of old sites and the rehabilitation and revegetation of new drillsites were combined into one large program.

The litter consisted mostly of empty 55-gallon fuel drums. During the Pet -4 program and the ensuing operations, fuel of all kinds was supplied in drums that were abandoned once the contents had been used. Metal deteriorates very slowly in the Arctic. Tens of thousands of these drums were scattered throughout the Reserve, especially in coastal areas, at drillsites, construction sites, and along the trails followed by old tractor trains and geophysical

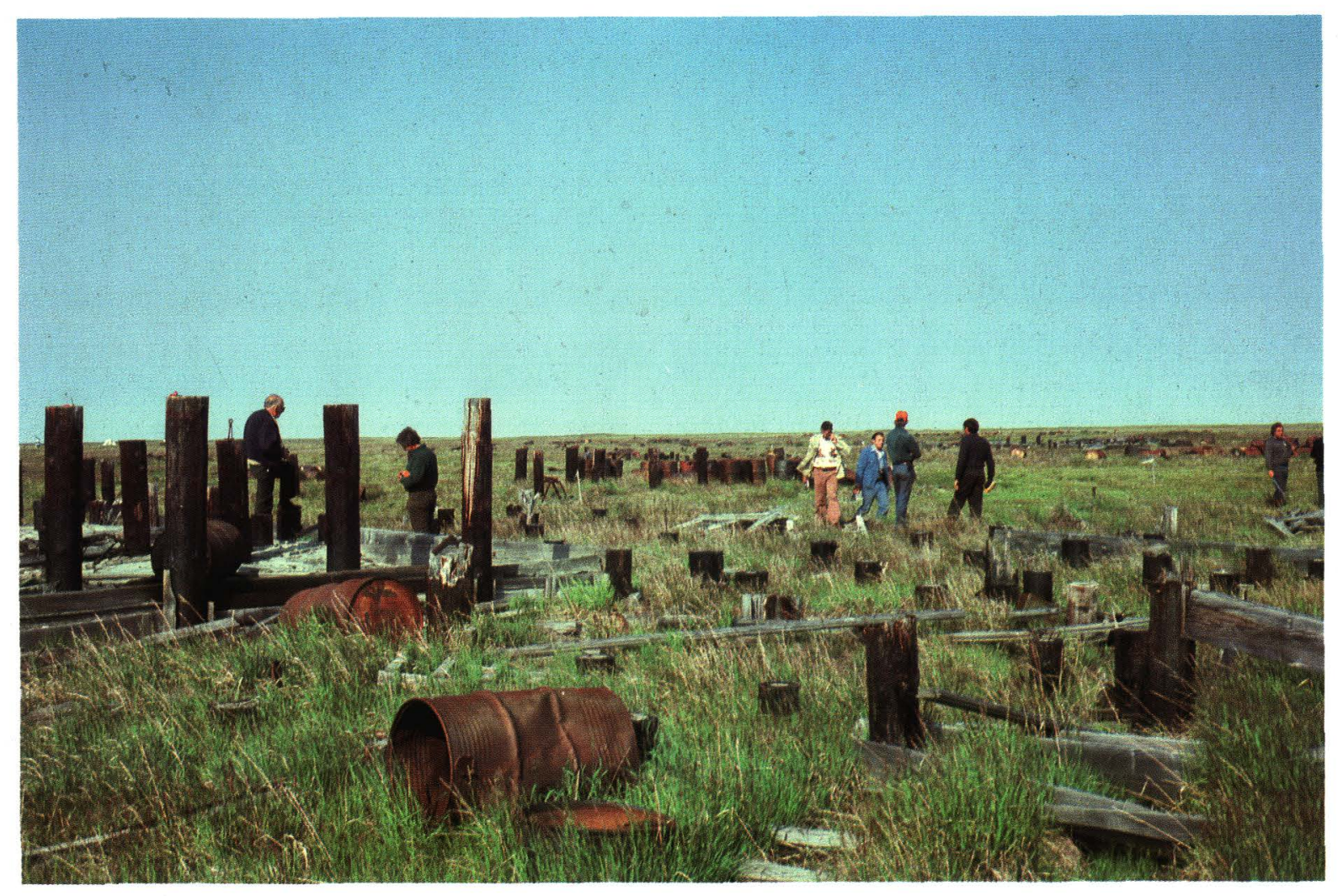

Fish Creek drillsite, from the 1949 season, as it appeared in 1977 before cleanup. Photograph by John Schindler. 
and geologic survey crews. In 1976, the Navy picked up 9,019 barrels, and this was only a beginning.

In 1977, under USGS management, cleanup of old sites was continued, together with rehabilitation and revegetation of the latest drillsites. A barrel crusher was obtained to reduce the bulk, and in $1977,16,743$ barrels were crushed, and 485 tons of debris collected, burned, or stockpiled. In 1978, 1,235 tons of debris was burned or stockpiled. In 1979 , the summer cleanup crews worked out of tent camps near the sites, thus cutting the cost of daily commuting from a base camp. During that summer, more than 10,000 tons of debris was handled, burned, or stockpiled for later disposal.

The U.S. Navy hauled much of the debris at Barrow to Seattle for final disposal-a difficult and expensive process-because it was thought that burial in permafrost ground would be difficult and environmentally unacceptable. However, hauling to the "South 48 " was very expensive and simply moved the problem to another region. Thus, in 1980, burial at carefully selected sites was begun. The burial plan included stripping away the organic overburden and stockpiling it to one side, then excavating a pit of sufficient size to hold the debris, placing the debris in the pit, compacting it, and carefully backfilling with the original material so as to cover it at least 2 feet deep. Because the overburden was generally exposed to the winds and cold for less than 2 days and then protected by blown snow after replacement, many plants survived. This meant that the area recovered far more quickly than an area seeded with grass.

The first step at rehabilitation of a drillsite was routine cleanup. All the debris was picked up and burned or returned to a disposal site when the drilling was completed. Pilings were cut off below ground surface, if possible, and pile caps and sills were burned. Final cleanup took place after the ground had thawed.

After the cleanup stage, the work required depended on the drill-pad design. For thick pads, the pad elevation was lowered, and the excess pad material dumped into the reserve pit. Thinner pads required no rehabilitation, and the five insulated pads required only precautionary rehabilitation. It was important that the Styrofoam remained buried because otherwise it could become a source of litter.

After cleanup, the site was ready for seeding. Active seeding was done before the end of June; dormant seeding was done after the first freezing temperatures of the fall. About 50 pounds per acre of seed mixture was sowed, and 600 pounds per acre of nitrogen-phosphorus-potassium fertilizer was applied. Seed was worked in with tractor tracks



Part of the cleanup operation at old drillsites consisted of cutting off pilings "below grade" of the drill pad. Photograph by John Schindler.

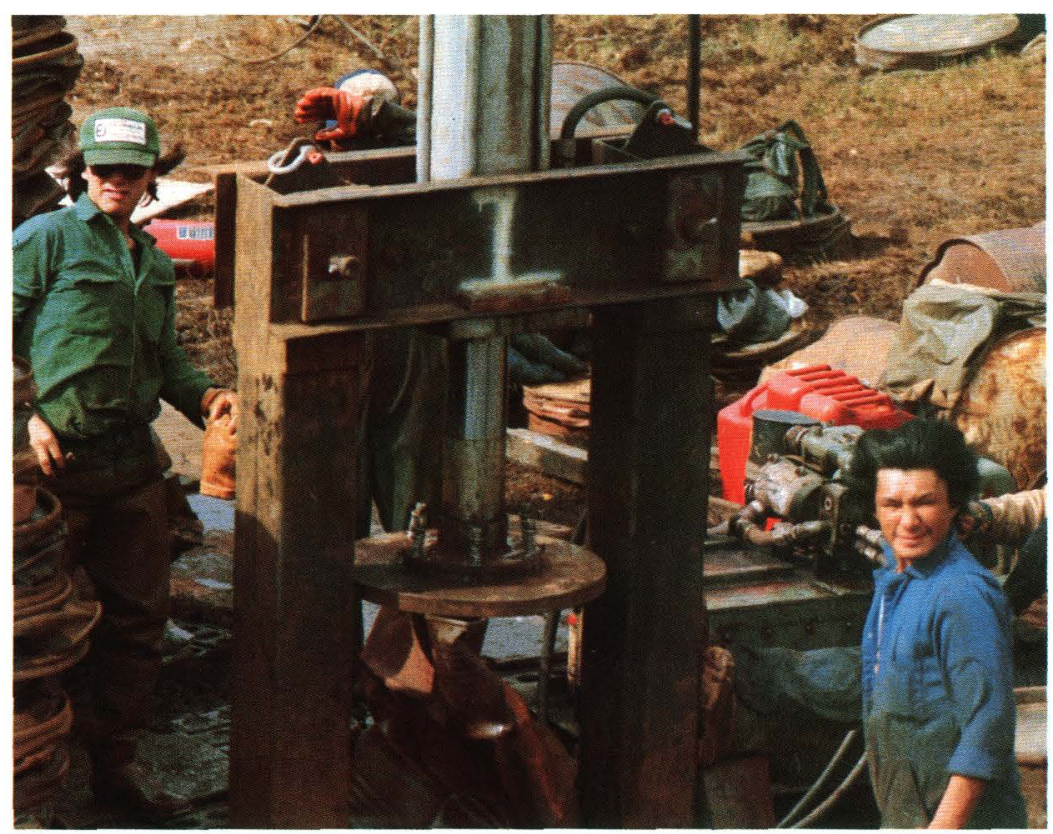

Barrel crusher. Photograph by John Schindler. 


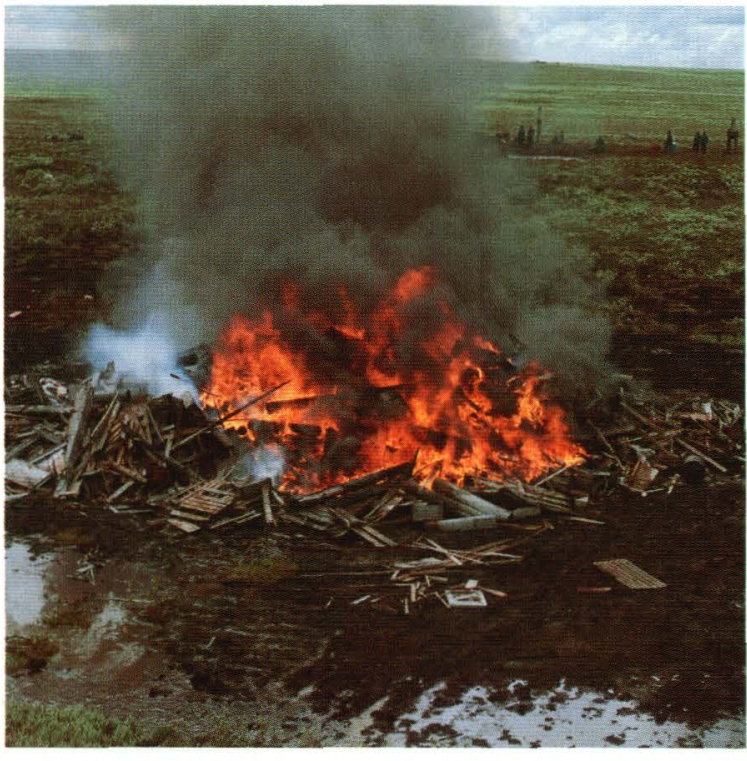

Burning debris at the Oumalik cleamup site. Photograph by John Schindler.

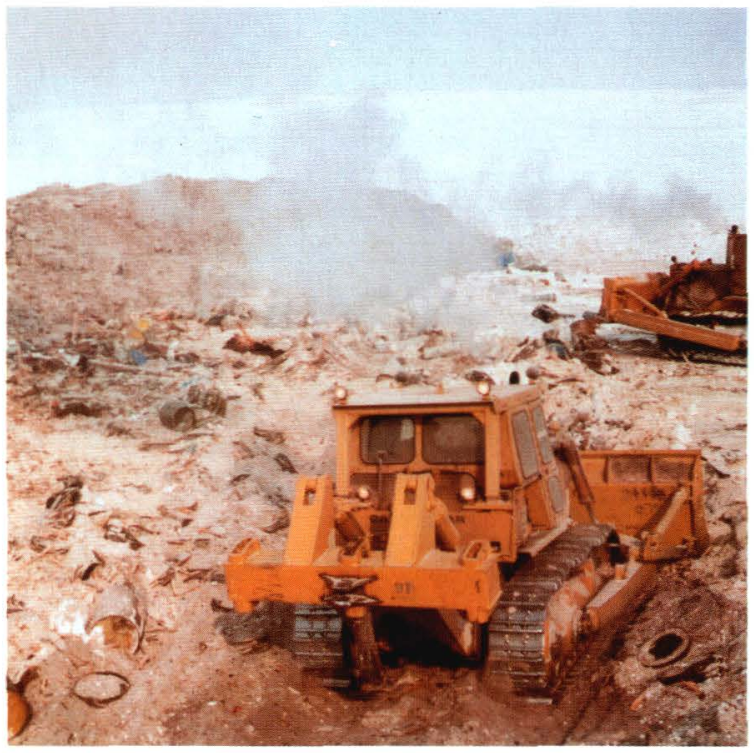

Some incombustible material unas disposed of in landfills approned by the State of Alaska. Photograph by John Schindler.

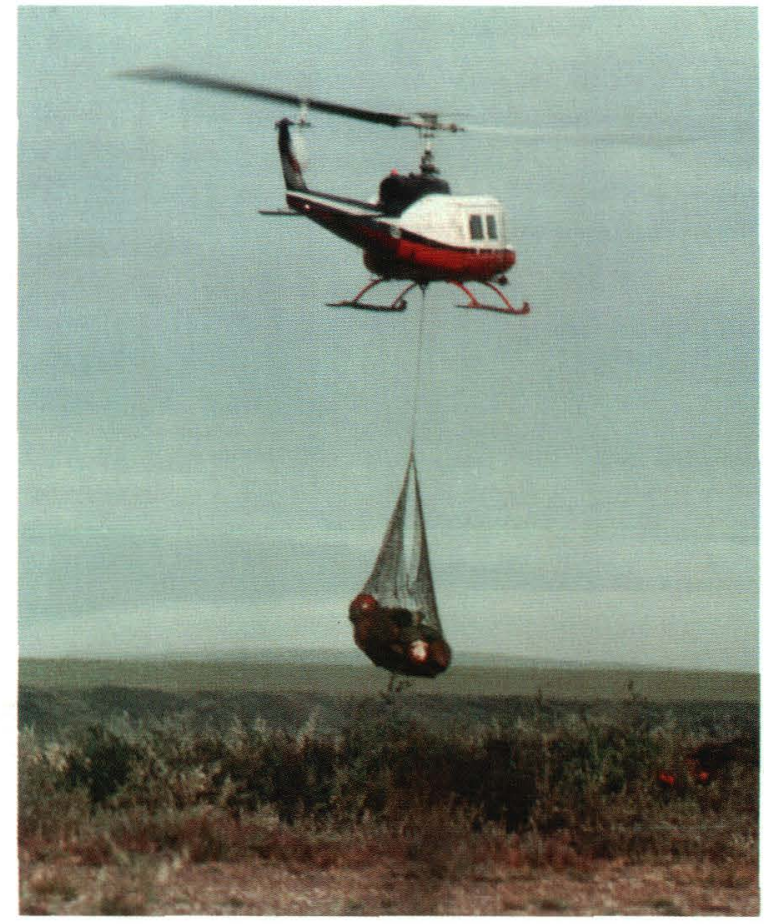

Helicopters were used during the cleanup program for transporting debris to the burial site at Grandstand. Photograph by John Schindler.

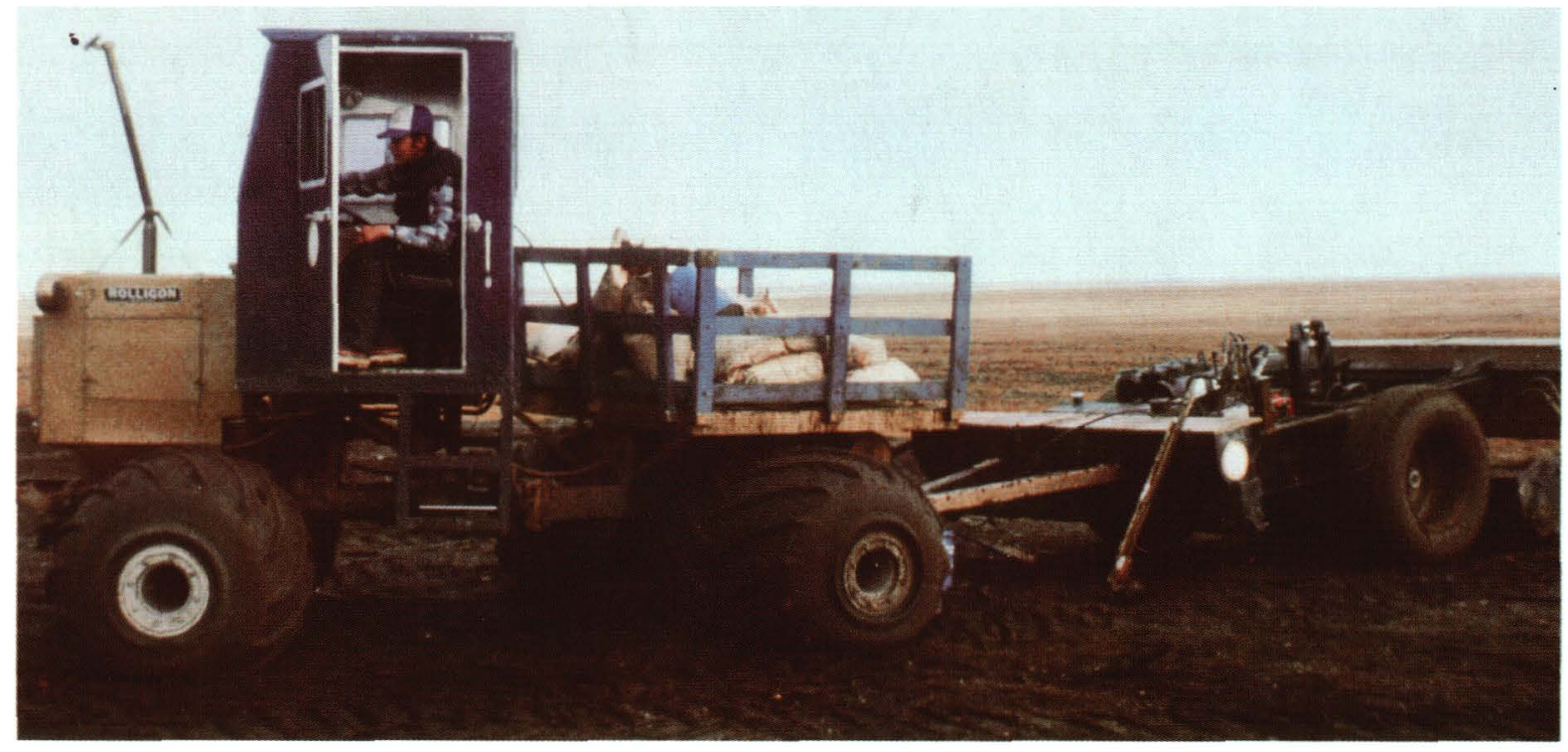

A revegetation Rototiller prepares the soil at the Walakpa No. I test well. Photograph by John Schindler. 

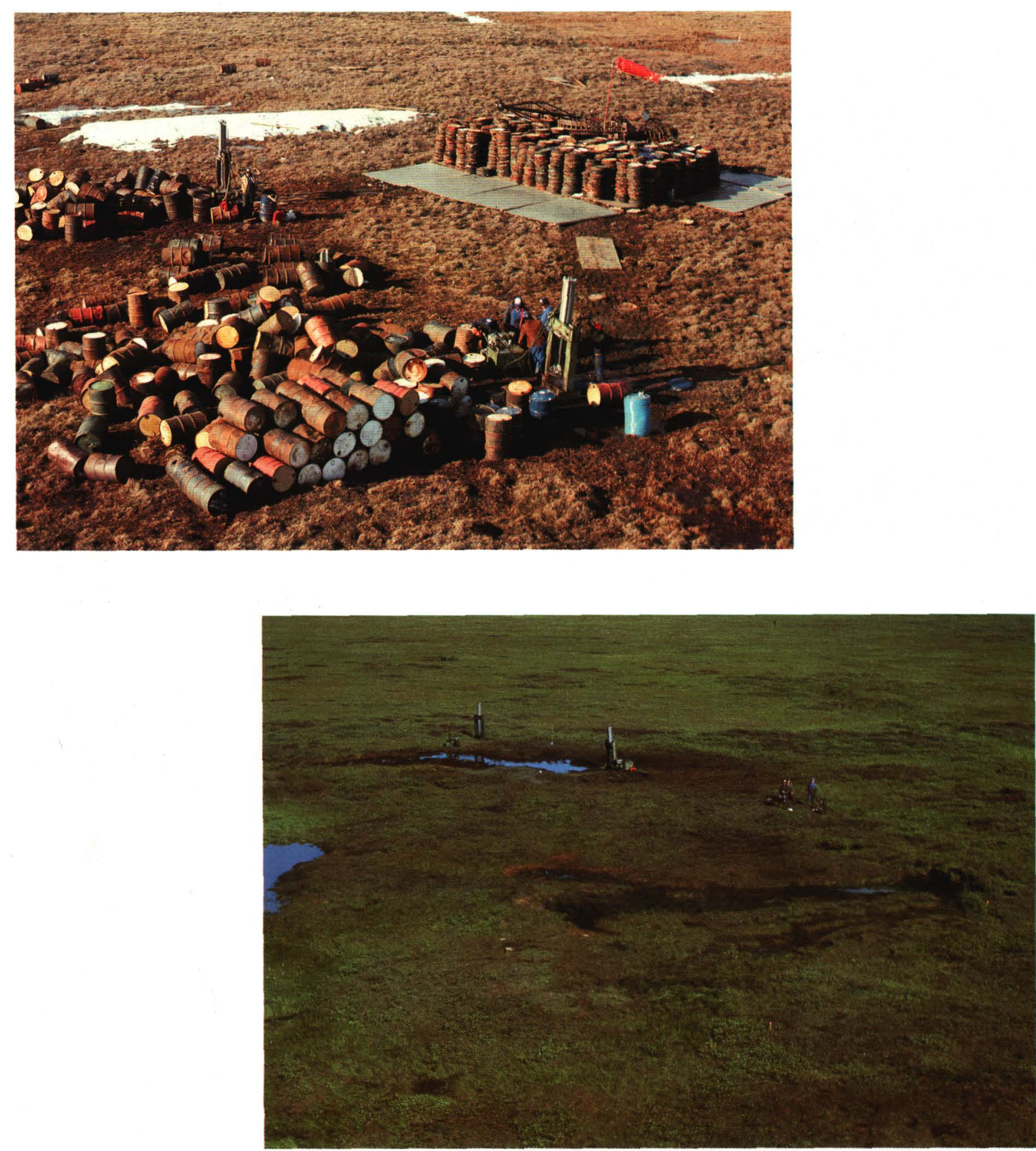

Before and after vnews of the Oumalik wellsite. View on the right was taken less than a year after the cleanup. Photographs by John Schindler. to ensure soil/seed contact and prevent wind erosion. This method proved to be moderately successful in the inland locations but failed along the coast. After considerable experimentation, it was determined that tundra bluegrass was best for the coastal locations. This bluegrass is native to the North Slope and allows for other native mosses, lichens, and grasses to reappear. The fertilizer was spread by a helicopter with a special hopper, then worked in to a depth of 4 inches below the surface with a cultivator

Damage by traffic over winter trails was slight and mostly was confined to the heavily traveled trails near Camp Lonely and Barrow. A "cropduster" airplane was used to distribute fertilizer in these disturbed areas. Both the ontundra ice roads and the runways disappeared with the thawing of the active layer in spring, but in some places the tundra would turn brown or dark green. The brown color was caused by freeze-burn of the vegetation through the ice, which did not insulate as well as the snow cover. The green color resulted from a depression in the surface caused by excess weight, creating wetter conditions and more plant growth. Only a small percentage of the 15,000 line-miles of seismic work became green or brown trails. In any case, these colors were short lived and disappeared within 5 years.

Borrow sites were judiciously chosen and carefully mined, and thus required little rehabilitation. Most borrows were in areas flooded by the spring runoff, and so after a year the sites were indistinguishable from the surrounding areas. In selecting a borrow site, a source was chosen where mining would have no effects that could not be corrected by natural processes within a couple of years. The site was excavated only to the normal water level to avoid excess erosion.

The cleanup and rehabilitation program restored the appearance of the NPRA. By the removal or burial of debris, followed by an intensive revegetation program, disturbance to the environment has been minimal. 
quickly saw the advantages of natural gas and petitioned the Congress for permission to use it. The Congress passed favor ably on their petition, and by 1965 Barrow had completely converted to natural gas. The abundant cheap fuel attracted additional people, and the U.S. Navy slowly developed the South Barrow gas field to its present size (six producing wells) in response to the growing demand. The gas produced from the Barrow fields is about 95 percent methane.
In 1974, dwindling reserves of gas in the South Barrow field caused the Navy to drill Barrow No. 12, an exploratory well located about 6 miles east of the original field. The location of this well was based on a seismic survey of the area in 1973. The well penetrated the reservoir sand but did not produce at commercial rates. In early spring 1977, Barrow No. 14 was completed and proved to be a good gas well. It is about half a mile east of Barrow No. 12 in what is now called the East Barrow gas field.

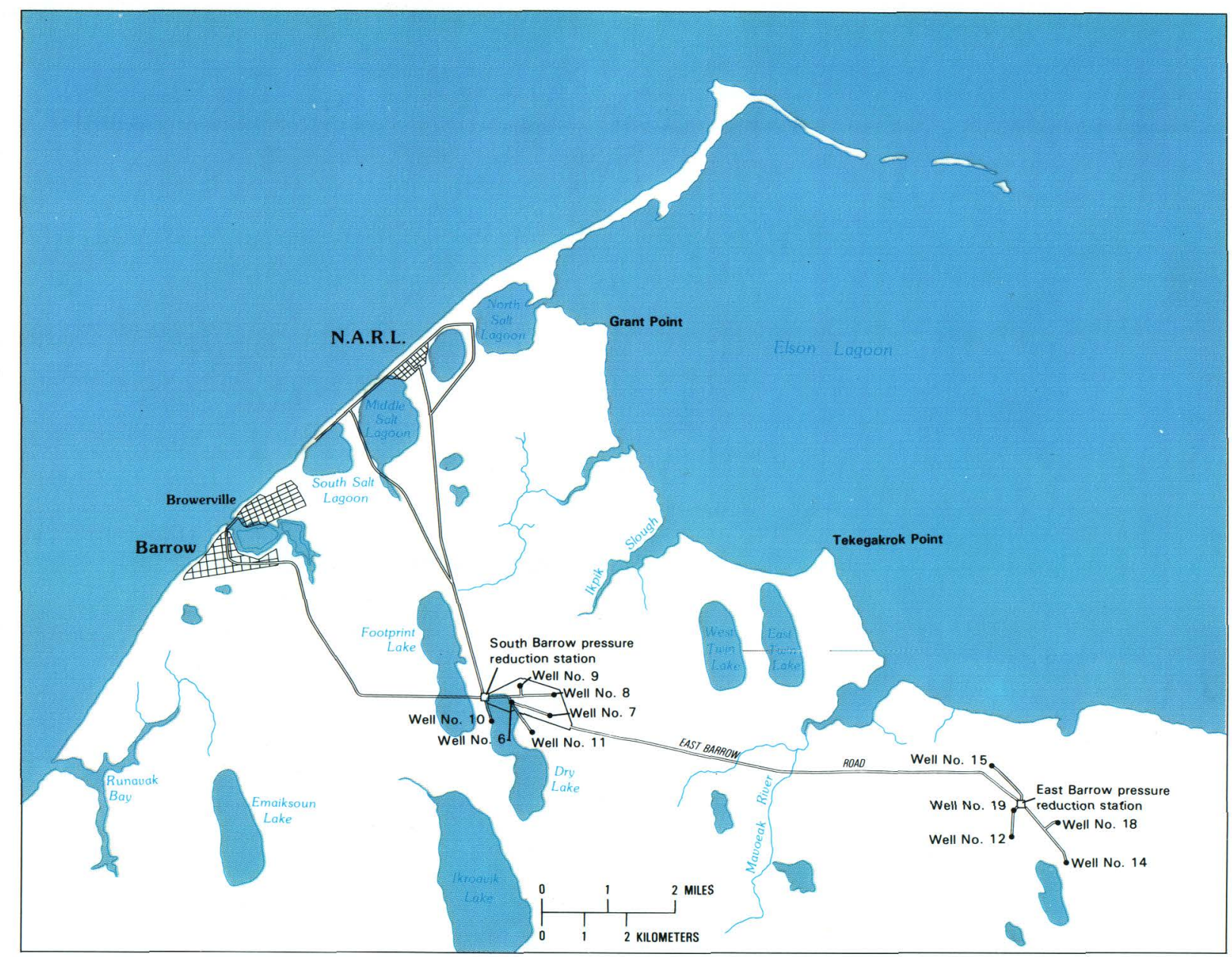




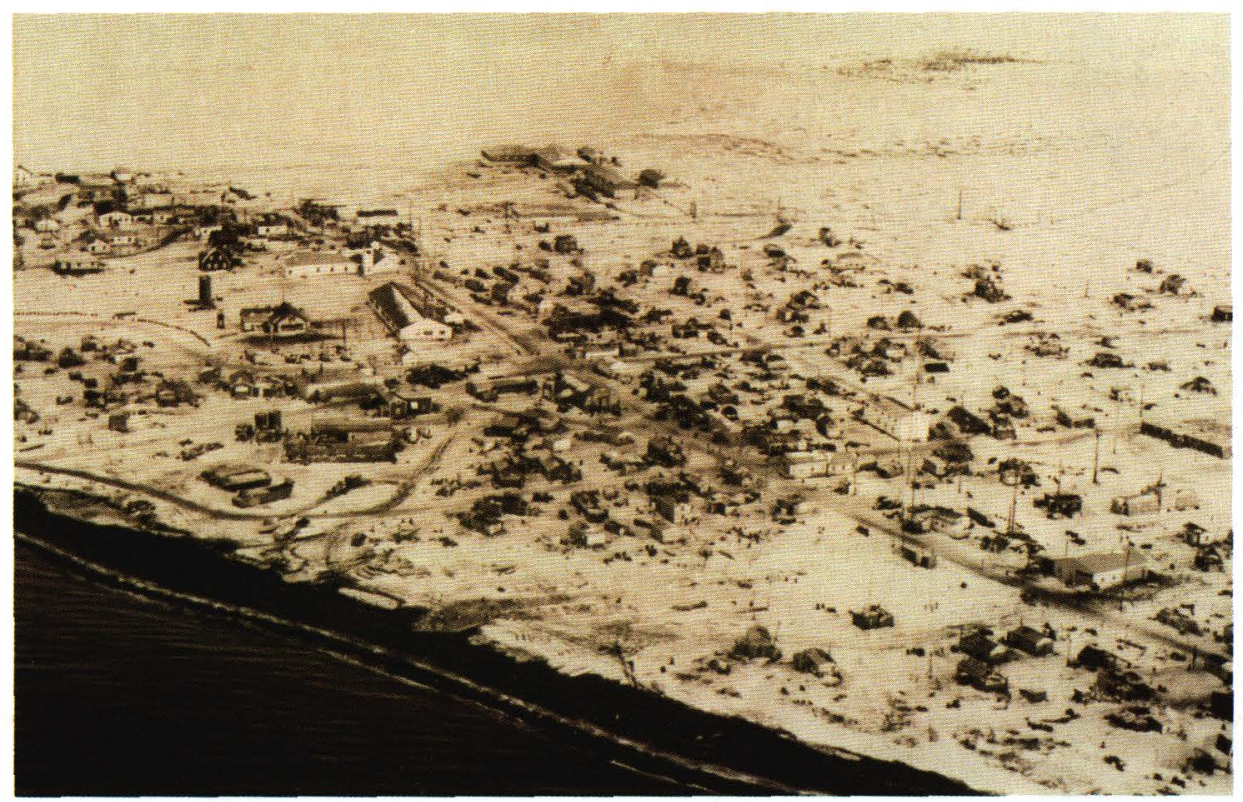

Aerial photograph of Barrow, probably taken in 1963 before completion of the gas-distribution system. Larger buildings are part of Federal compounds: the U.S. Weather Service (right foreground), the Bureau of Indian Affairs (background), and the Public Healt Service (background). View northeastward. Photograph by John Schindler.

Thousands of oil-filled barrels were delivered to Barrow by barge during the Pet-4 program in 1944-53.

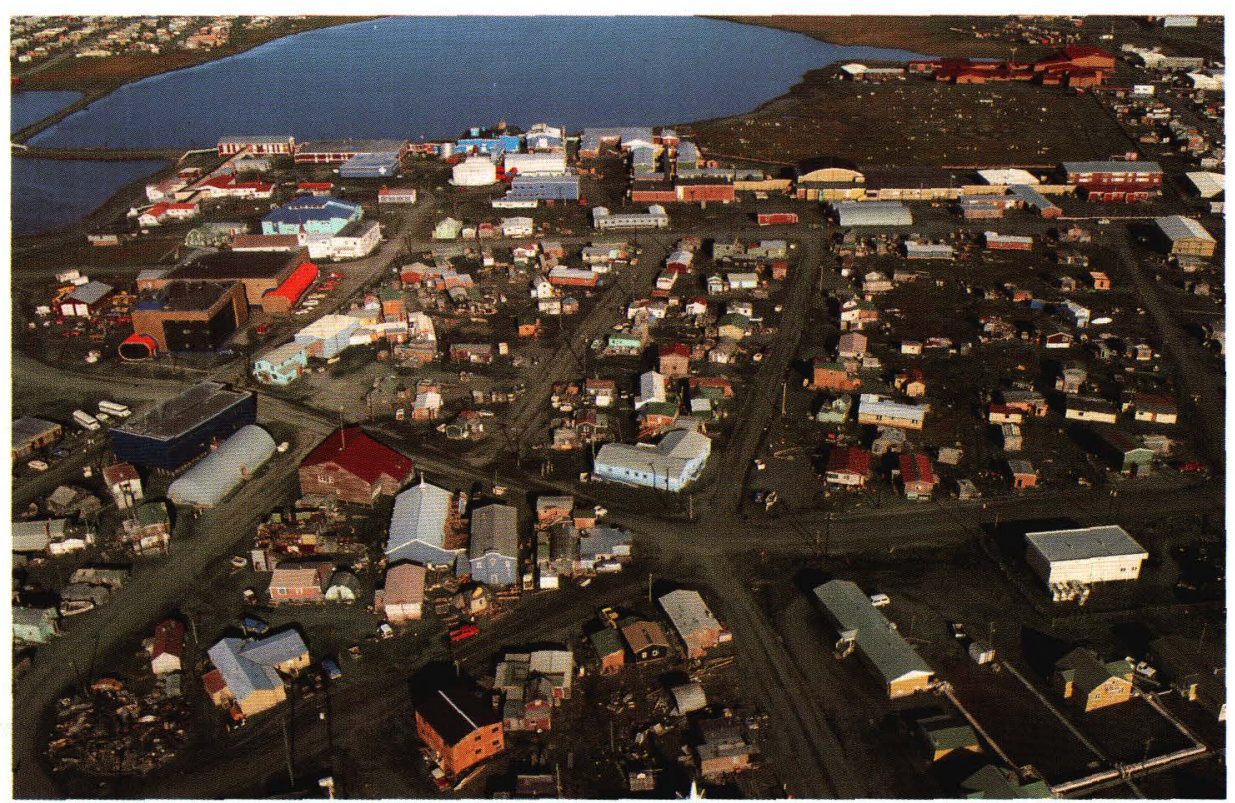

Barrow, 1983. The most recent census counted about 3,500 people as year-round residents. Photograph by Robert Lantz.

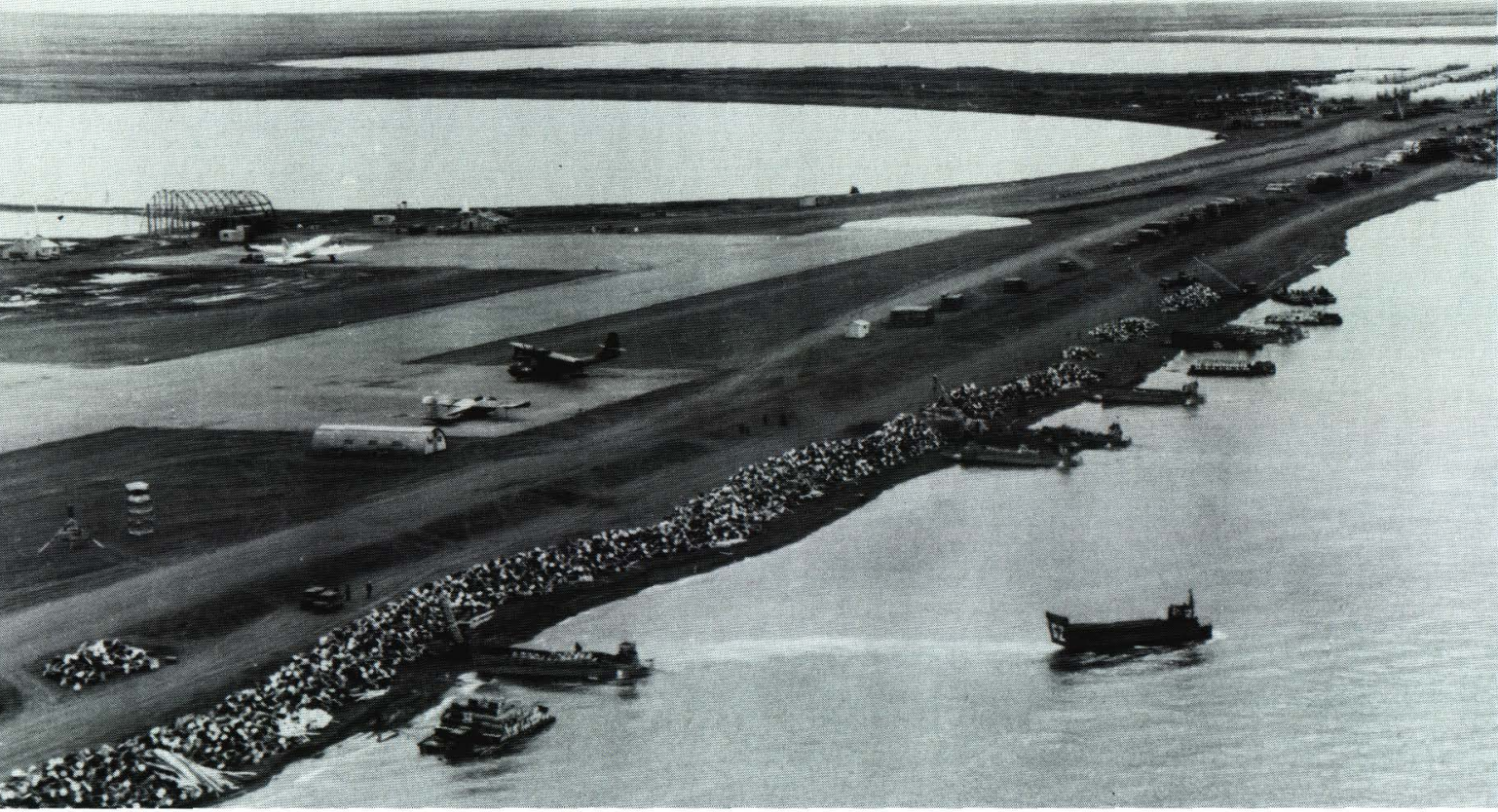




\section{The role of the USGS at Barrow}

Gas from the South Barrow field was supplied to the townspeople at a subsidized price, and no limits were imposed on its use. Over the years, the entire Barrow community has become completely dependent on Barrow gas as the source of heat and power-necessities in this cold, harsh climate.

The Naval Petroleum Reserves Production Act of 1976 (Public Law 94-258) transferred jurisdiction of NPR- 4 from the Secretary of the Navy to the Secretary of the Interior, effective June 1, 1977. That law directed the Secretary of the Interior to "develop and continue to produce the South Barrow gas field or other such fields as may be neces- sary to supply gas at reasonable and equitable rates to the Native village of Barrow and other communities and Federal installations at or near Point Barrow, Alaska." The Secretary of the Interior delegated that responsibility to the USGS. The USGS supplied natural gas to the Barrow community from June 1 , 1977, until October 1, 1984.

The Congress passed Public Law 98-366, the Barrow Gas Field Transfer Act of 1984, on July 17, 1984. This law relieved the Secretary of the Interior of his responsibility for supplying Barrow and the nearby Government installations with natural gas. That responsibility was assumed by the North Slope Borough on October 1, 1984, in return for $\$ 30$ million and title to the gas fields. The USGS is to furnish technical assistance to the borough on request until October 1, 1989.

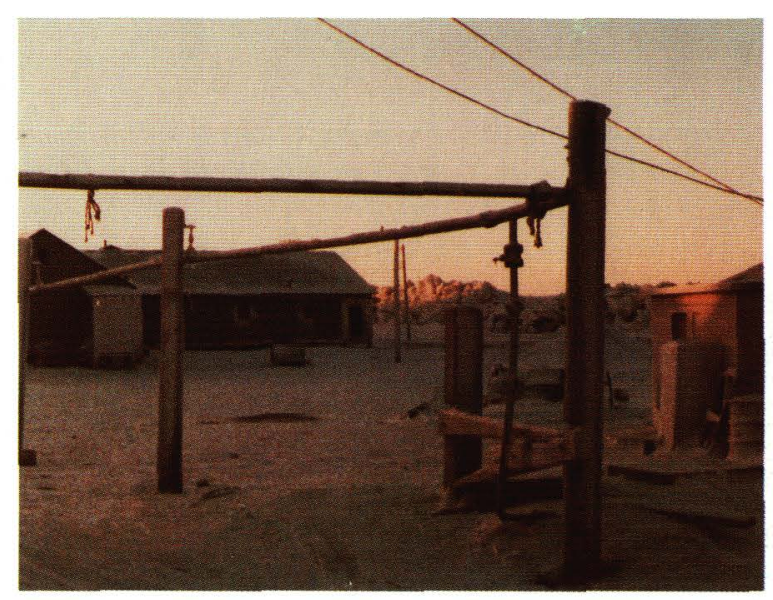

Old gas-distribution system suspended from stanchions. Photograph by Robert Lant.

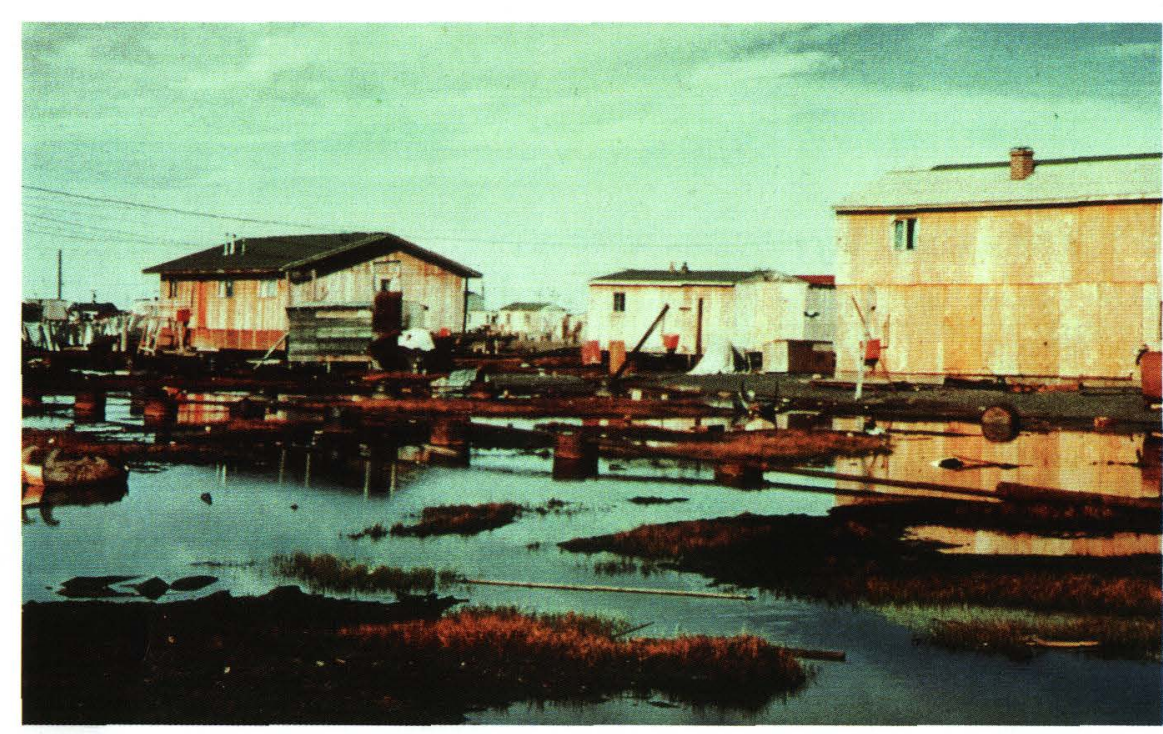

Old gas-distribution system on barrels. Photograph by Carroll Livingston.

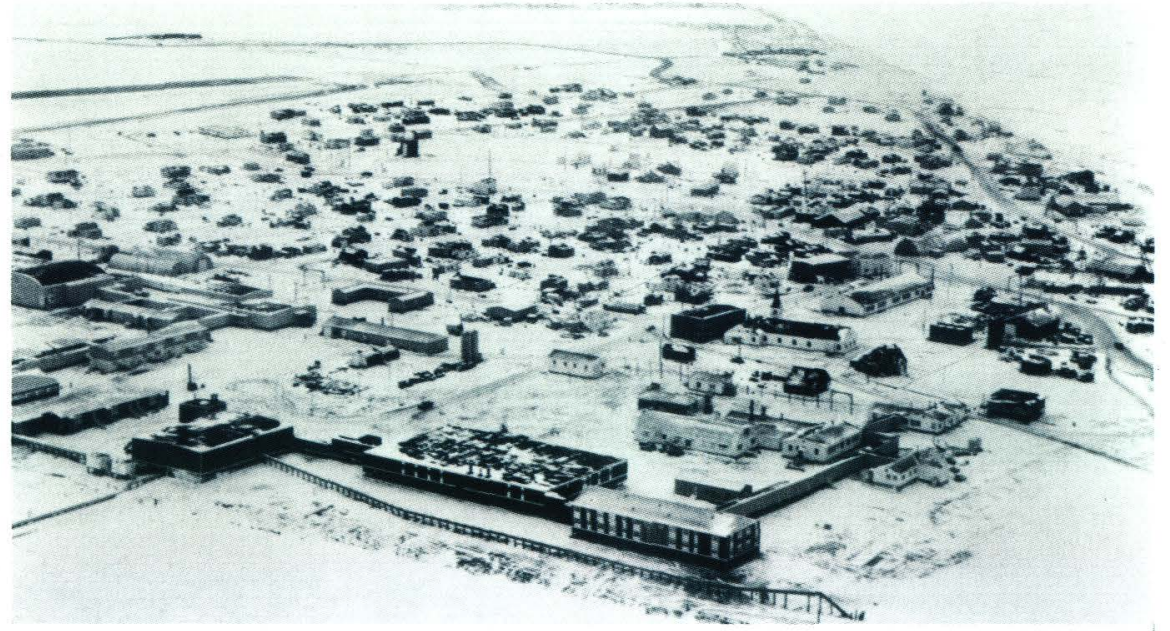

When the Congress approved the sale of gas to the village, a temporary distribution system was built above ground from material left over from the Pet-4 program. Supported on barrel halves or by stanchions, it was subject to leaks and accidental breaks. This photograph of Barrow was taken in 1963 or 1964 during construction of the distribution system. What appear to be fine dotted lines in the foreground are barrel halves awaiting the gasline. This "temporary" system was replaced in 1982 after some 18 years of service. Pho tograph by Robert Lantz.

THE NATIONAL PETROLEUM RESERVE IN ALASKA 


\section{Gas consumption}

All of the gas produced from the Barrow fields was consumed by Federal installations until 1964, when gas was also provided to the village. The volume of gas used by the village that first year (1965) was about 140,000 thousand cubic feet (MCF), or about 36 percent of the $388,846 \mathrm{MCF}$ that was produced; the other 64 percent was used by Federal consumers. The U.S. Navy originally charged Barrow $\$ 0.50$ per MCF but reduced that price to $\$ 0.324$ per MCF in 1976 , which is the current price.

When the responsibility for the gas fields passed to the USGS in 1977, the village was using a little more than half of the gas produced and was just beginning a civic improvement program designed to elevate the standard of living in Barrow to that of a typical small town in the "South 48 ." The goalsrunning water, flush toilets, modern houses with modern conveniences-is near reality, powered by subsidized natural gas. More than 300 new homes have been built in the past 5 years. Floorspace in Barrow is estimated to have increased more than a hundred fold since 1965 to a present 1.5 million square feet. In 1982, the town of Barrow consumed 925,000 MCF of gas, which amounted to 74 percent of the total volume of gas produced during that year. Gas consumption in Barrow increased by 23 percent in 1982 over 1981 and has increased a total of 660 percent since 1965.

Federal gas usage, which has remained relatively stable over the past 5 years, is divided among several installations; the NARL, the DEW-line radar station at Barrow, the Public Health Service Hospital, the Federal Aviation Administration, the National Oceanic and Atmospheric Administration (NOAA) Observatory, the Post Office, and the National Guard Armory. Of these installations, the NARL is by far the largest consumer.

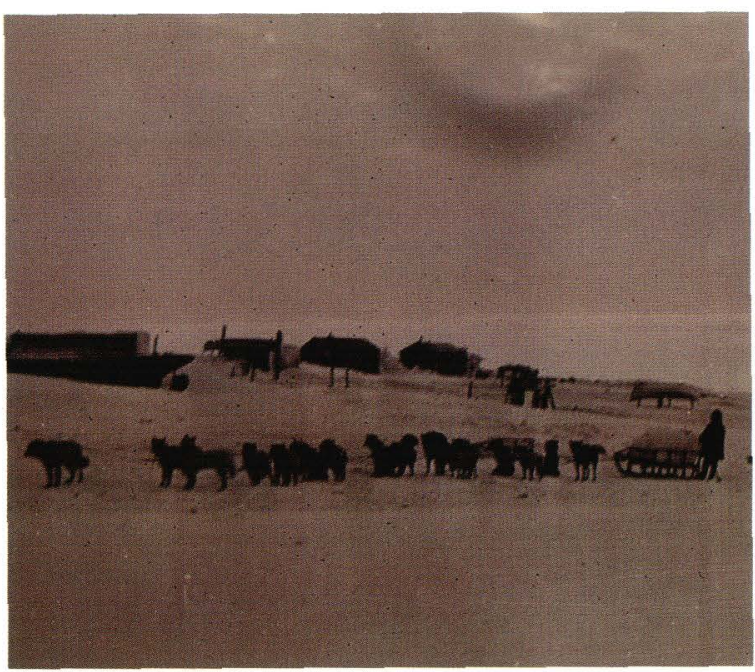

Winter view of Barrow, before the advent of the Pet-4 program. Houses shown are probably typical of the time. If you look closely, you will see 17 dogs hooked to the sled. Dog teams have now been almos completely replaced by snowmobiles. Photograph by Charles Brower.

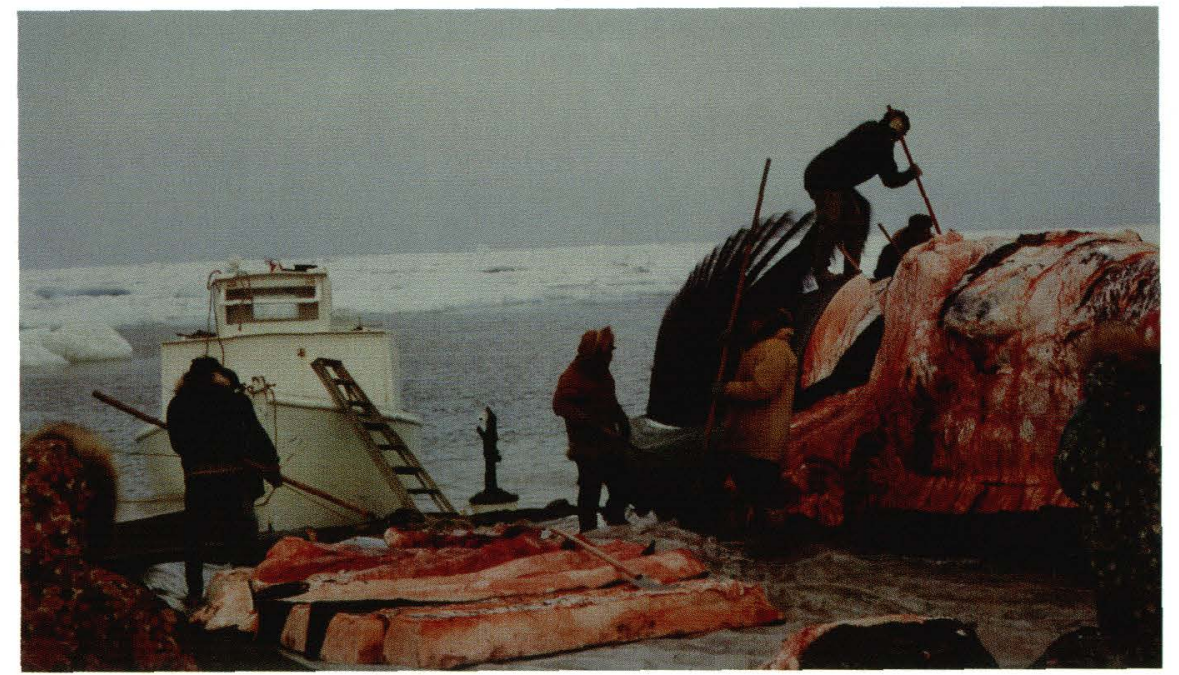

Present-day whale hunting at Barrow. Much ritual and ceremony are involved. Photograph by John Schindler.

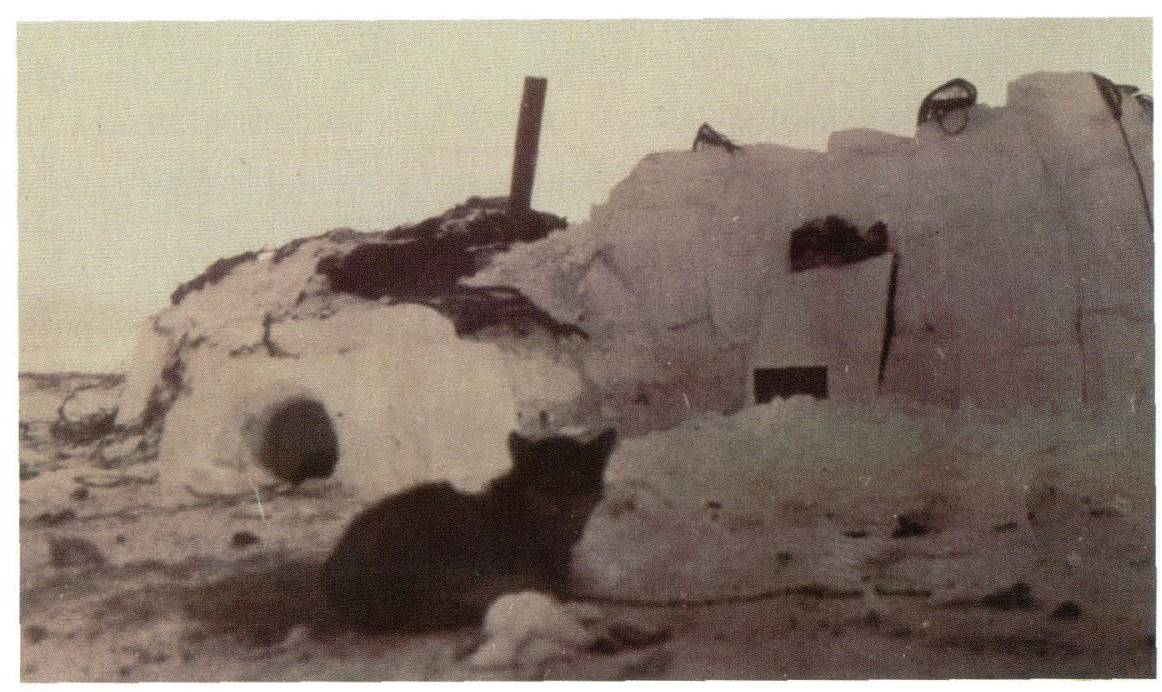

Eskimo house at Barrow in the 1920's. In the old Eskimo culture, fuel in the Barrow area consisted mostly of driftwood, animal oil, and moss, although coal, oil shale, and oil from the seeps were used at times. Fuel was crucial to survival. Homes were small. The sources of heat and light - the cook stove and oil lamp-were the centers of indoor activities and family social life. Photograph by Charles Brower. 


\section{Gas production}

On October 1, 1984, operation of the gas fields at Barrow was taken over by the North Slope Borough. Before that date, the gas fields were operated and maintained by a contractor under USGS supervision. This contractor was based at the old NARL camp that the U.S. Navy decommissioned in 1981.

The NARL is a large installation and requires considerable maintenance in the harsh climate. The camp is by necessity a standalone operation. There are no public utilities to furnish water supply, sewage treatment, or electricity; all such services must be handled within the camp. The gas-field road network also requires the almost constant use of several pieces of heavy equipment.

When the USGS supervised the operation, the gas fields themselves were constantly watched by gasfield operators aided by a remote monitoring system installed in 1982. Every effort was made to ensure an uninterrupted flow of gas. It was a sizable task, requiring a workforce of about 35 people and costing about $\$ 6$ million a year.

Aerial views of Barrow taken from nearly the same position about 20 years apart (upper, 1963; lower, 1983). Growth in the number and size of houses is readily apparent and explains Barrow's soaring demand for gas. The cluster of buildings in the U.S. Weather Service compound (right foreground) remains about the same. Photographs by Robert Lantz and John Schindler.
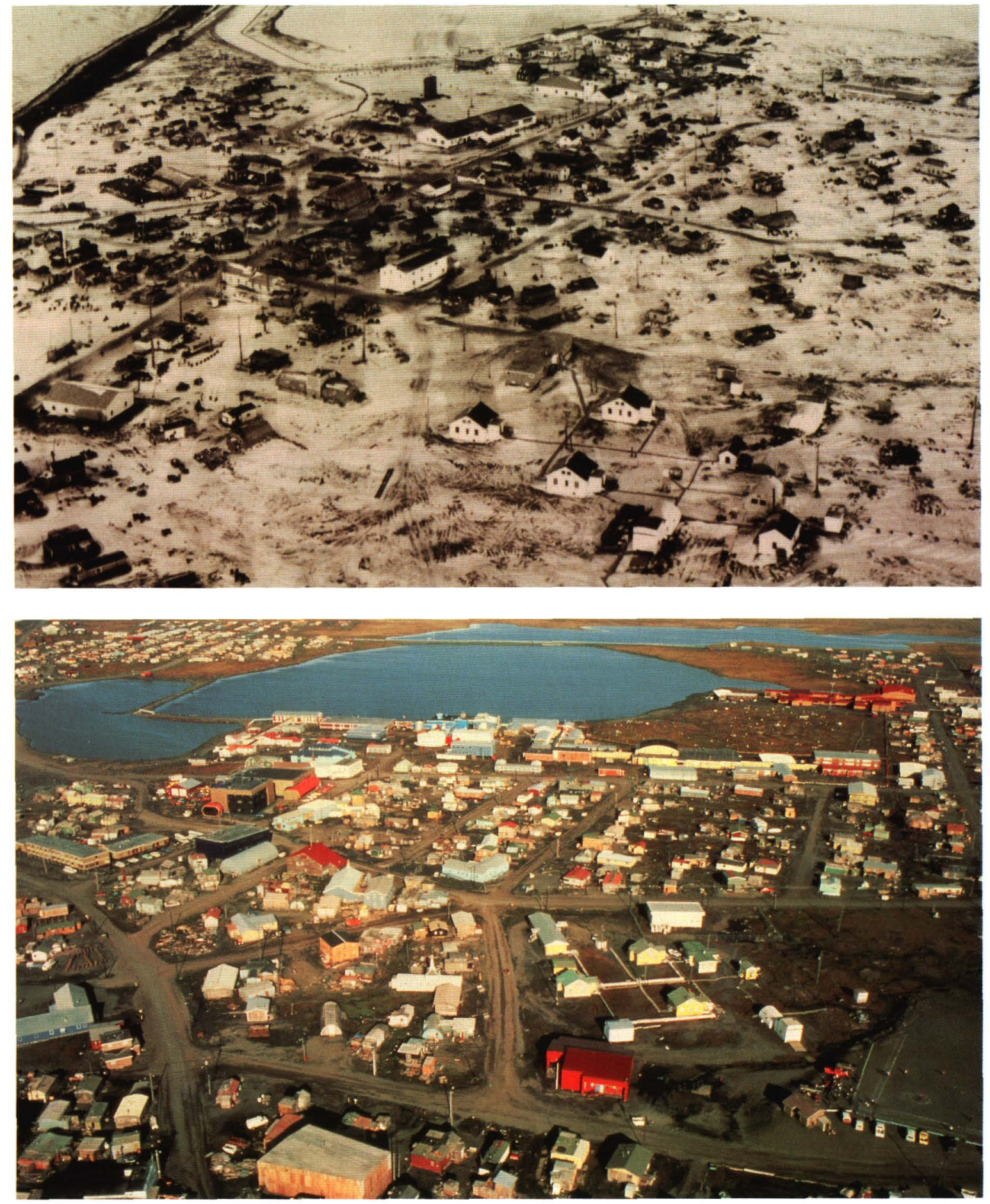
The Barrow gas fields themselves are rather typical except for their location and the pervasiveness of permafrost. Permafrost in the area of the producing fields extends from the surface down to about 1,000 feet. The annual mean temperature at Barrow is about $10^{\circ} \mathrm{F}$ and ice is a constant hazard. Water produced with the gas could accumulate in the wells, flowlines, or transmission lines, freeze, and cut off the flow of gas. The wells are not deep; the reservoir sand is above 2,500 feet, and the reservoir temperature is approximately a $\operatorname{cool} 60^{\circ} \mathrm{F}$. The wells are produced in a peculiar manner to utilize the cold permafrost that surrounds the upper part of the wellbore, so as to minimize the amount of water produced with the gas. Barrow gas flows through the annular space between the 7 -inch-diameter casing and the $27 / 8$-inch-diameter tubing. In most wells, gas flows through the tubing, but because the crosssectional area of the annulus greatly exceeds that of the tubing, a given volume of gas will travel much slower through the annulus. Thus, as Barrow gas flows slowly up through the freezing temperature of the permafrost, much of the water freezes out of the gas and falls to the bottom of the well. The tubing is only used to clean the accumulated water out of the wells. Alcohol is also injected into the gas stream to reduce still further the chances of ice blocking the flow of gas.

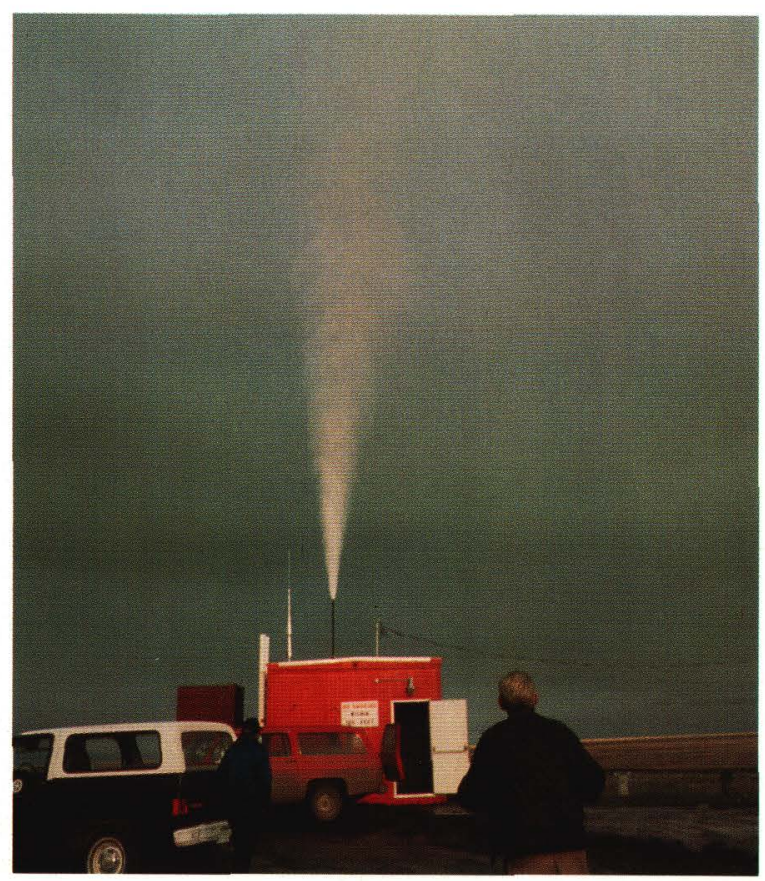

"Blowing" a well. Water vapor produced with the gas freezes out of the slow-moving gas and accumulates in the bottom of the well. To clean out the water, the flow of gas is diverted to the tubing, and the well is opened to the atmosphere. The gas flowing against only atmospheric pressure through the small-diameter tubing attains a high velocity and carries the water to the surface. The water is discharged into the air as vapor, forming a plume. Photograph by Robert Lantz.

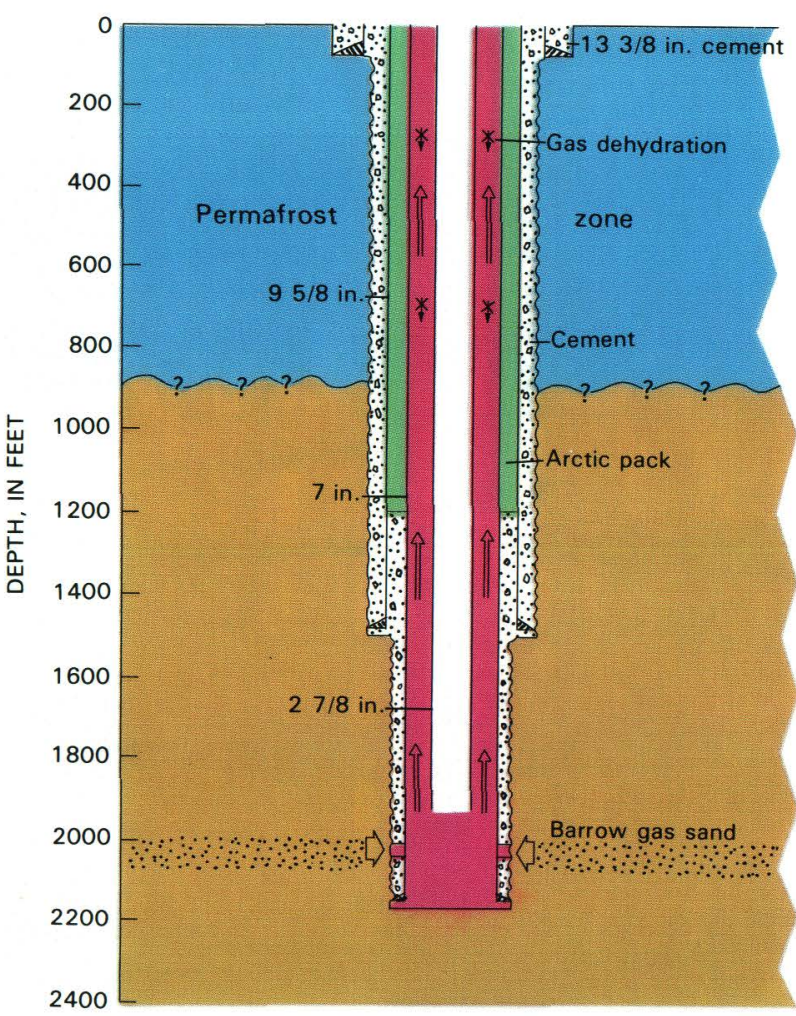

Detailed drilling, cementing, and casing program for a typical Bar row gas well. A 133/8-inch-diameter conductor pipe is set at depth of about 80 feet and cemented to the surface. A 121/-inch-diameter hole is drilled to approximately 1,500 feet; 95/8-inch-diameter casing is set in the hole and cemented to the surface. An 81/2-inch-diameter hole is drilled through the reservoir, in which 7-inch-diameter casing is run and cemented to the top of the cement left at about 1,200-feet depth, which is below the permafrost. Above 1,200 feet, the well is arctic packed (arctic pack is a nonfreezing cement substitute). The $2^{7 / 8}$-inchdiameter tubing is hung inside the 7-inch-diameter casing, which is perforated into the reservoir rock and thus allows the gas to enter the well. The gas is produced through the annular space between the 7inch-diameter casing and the 27/8-inch-diameter tubing.

Heaters at the East Barrow gas-production facility, where cold gas from the well is heated before the pressure is reduced. Passage of highpressure gas through a restrictive orifice ("choke" in gas-field language) to reduce the pressure results in a large temperature drop that could freeze water associated with the gas and cause blockage of the line. Heating the gas before choking prevents freezeups. Photograph by Robert Lantz. 
Gas from the individual wells goes through flowlines to a central producing facility located in each of the fields, where the gas pressure is reduced and regulated at a transmission pressure of about 225 pounds per square inch. The gas is also metered before entering the transmission lines that carry it to Barrow or the NARL.

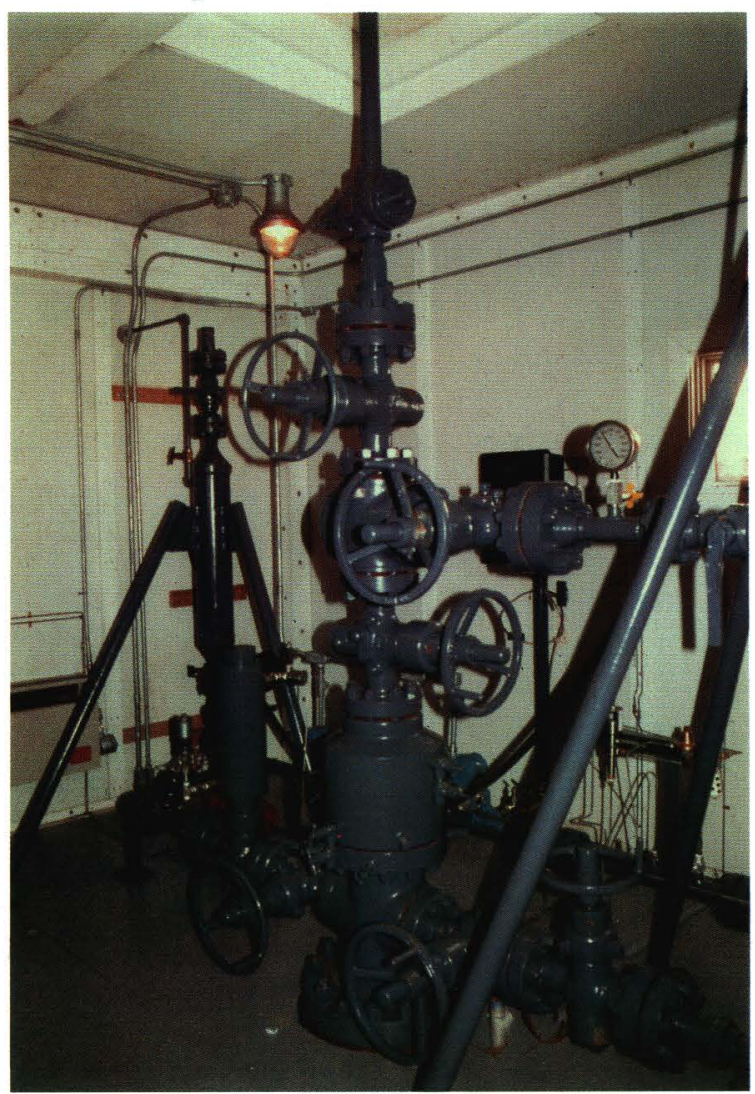

Interior of a wellhouse in the East Barrow gas field, showing a typical wellhead or "Christmas tree" through which the gas is produced. The wellhouses are heated and provide a relatively comfortable environment for the workers. Photograph by Robert Lantz.



Flowlines at the East Barrow gas-production facility. Photograph by David Fears.

Manifold where the flowlines enter the East Barrow metering and regulation (ME'R) building. Photograph by Robert Lantz.

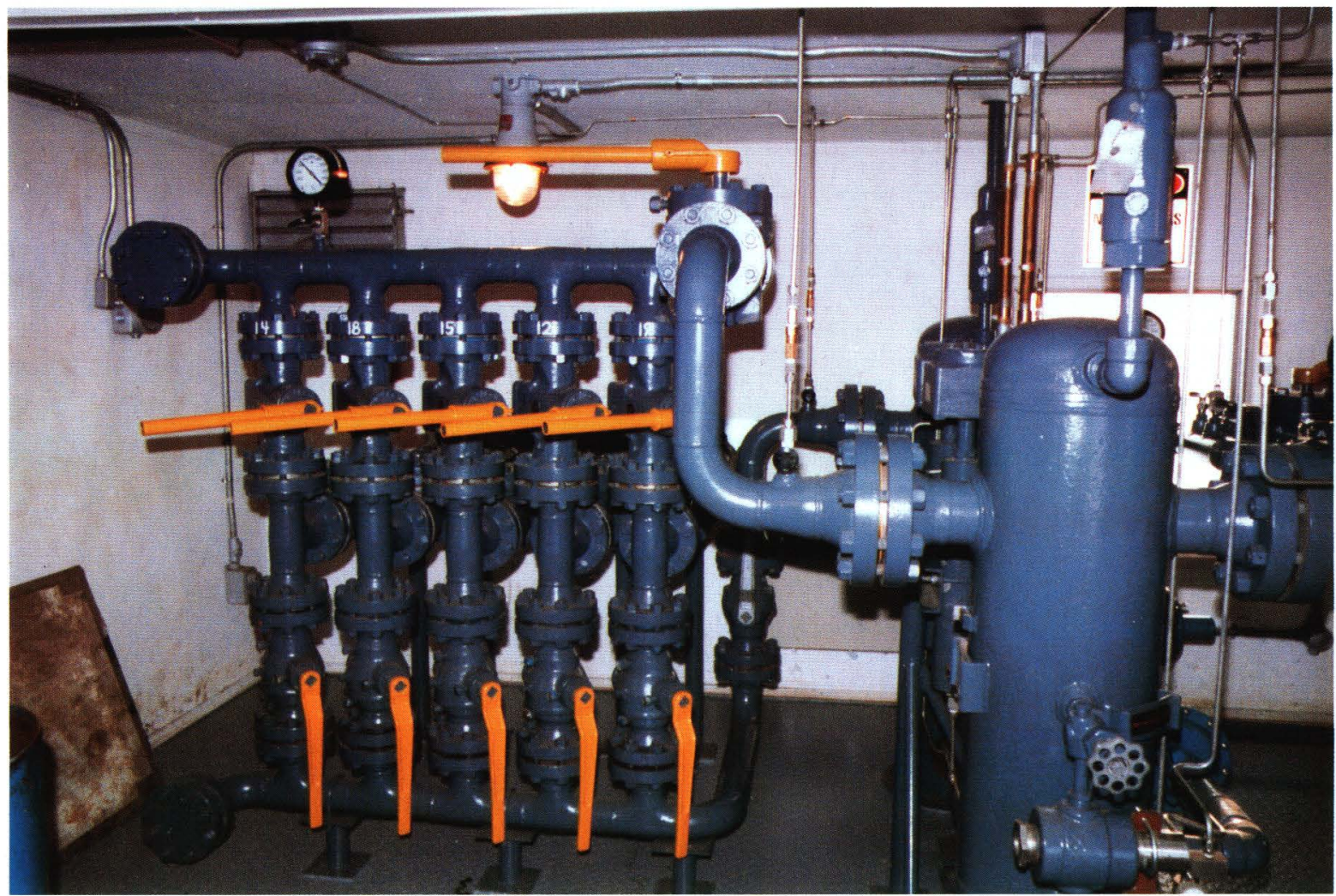

THE NATIONAL PETROLEUM RESERVE IN ALASKA 


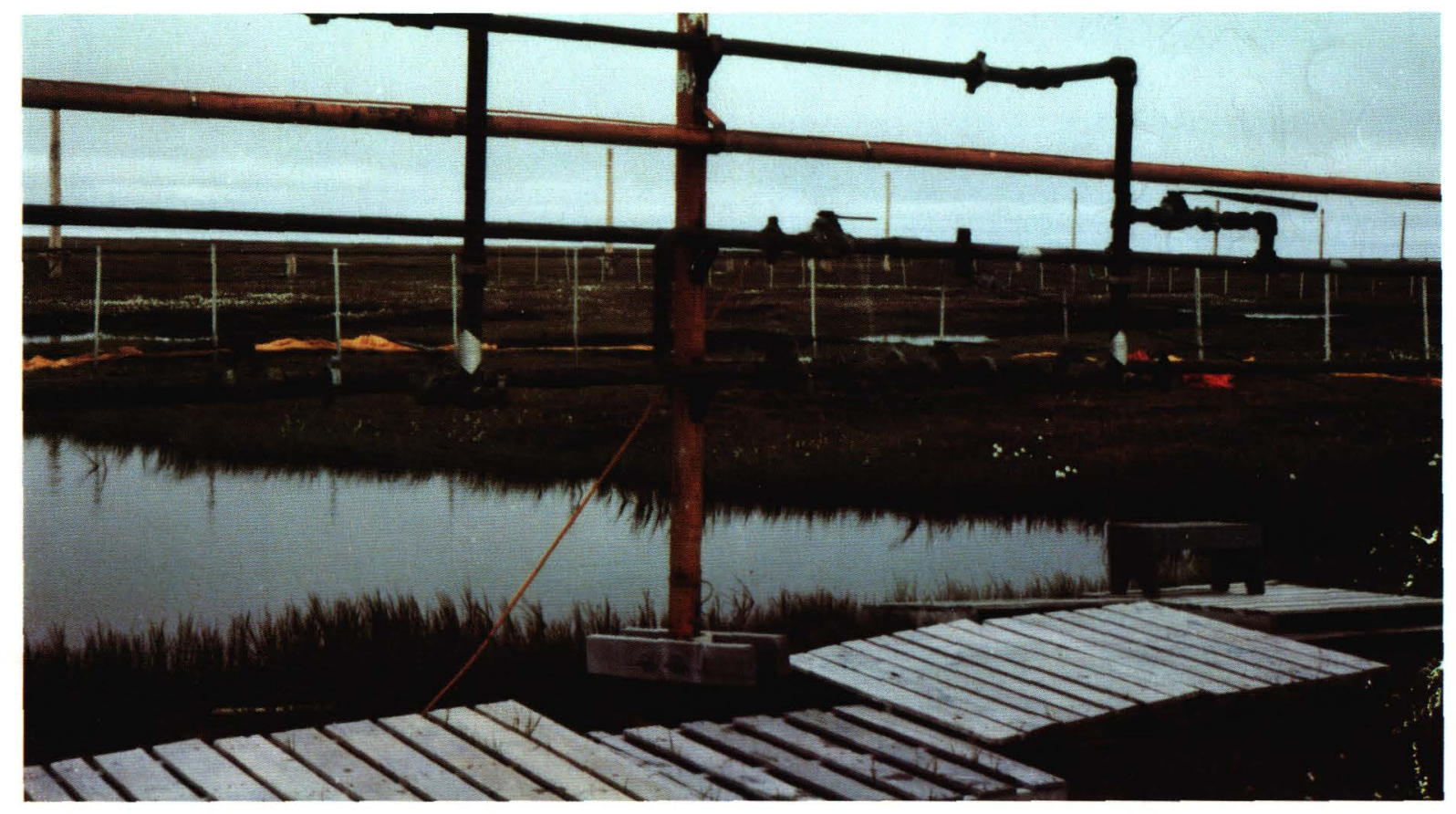

Flowlines into the central production facility in the older South Barrow gas field. Note the confusing, interconnected piping, threaded connections, and valving exposed to the weather. The South Barrow production facility and gathering system were largely built on site from surplus materials. As the number of gas wells increased, valves and pipes were added to accommodate them. The operators said "it just grew like Topsy." Photograph by David Fears.

View of the piping inside the $M \in R$ building at South Barrow. Photograph by Robert Lantz.

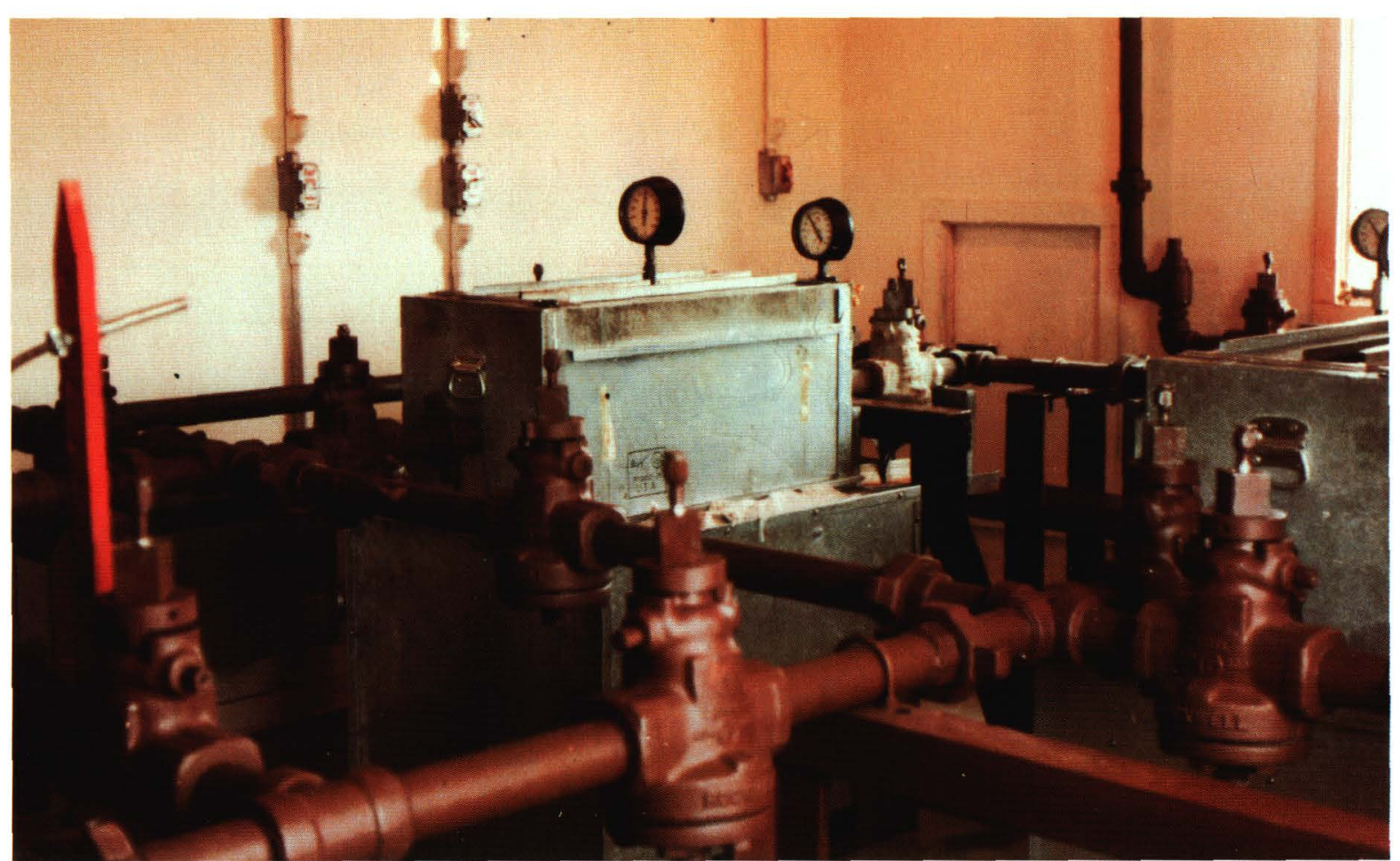




\section{Prospects for supplying future demands}

The South Barrow gas field originally contained about 27 billion cubic feet (BCF) of recoverable reserves, and the East Barrow field about 8 BCF. The gas accumulations in the South and East Barrow fields are on the rim of an approximately circular area containing chaotic structures, which the U.S. Navy called the "disturbed zone." Seismic surveys in the area of the disturbed zone indicate the presence of an additional untested rim structure, about the same size as the one at East Barrow, which, if filled with gas, might contain as much as $10 \mathrm{BCF}$ of gas. Another structure is about 7 miles south of the South Barrow field, near old Barrow No. 3-a dry hole completed by the Navy in late August 1949. This small structure, if filled with gas, might also contain as much as $10 \mathrm{BCF}$.

About 15 miles south of Barrow, a gas accumulation of unknown dimensions was discovered by the Walakpa No. 1 well, drilled by the USGS in February 1980. A confirmation well, Walakpa No. 2 , about 5 miles southwest of No. 1, was completed in February 1981. Both wells were tested extensively. The gas is contained in a stratigraphic trap formed by updip pinchout of the reservoir sand to the north, but additional drilling will be necessary to establish the lateral (east-west) boundaries of the field. The downdip (south) producing limit is also unknown; although the Walakpa No. 2 well is more than 500 feet deeper than the discovery well, it did not reach the lower limit of the gas field. The Walakpa gas field could contain a significant volume of gas if the trap is of large dimensions, as is presently believed.
As can be gathered from this discussion, the total volume of producible gas in the sparsely drilled Barrow district is not known with any accuracy. Basement rocks are closer to the surface at Barrow than anywhere else on the North Slope, and the rocks slope away from the Barrow high in all direc tions. All the wells drilled in the area to date have had some shows of gas, but reservoir rocks are scarce, and without an adequate reservoir, commer cial production is impossible.

Known gas fields in the Barrow area (shown in red). The areal extent of the Walakpa field is unknown. Contours show configuration of the Barrow gas sand in reference to a level plane (sea level). Heavy lines denote faults; $D($ down) and $U(u p)$ show relative positions of rocks on each side of the faults. Schematic cross sections through the gas fields are drawn along green lines $A-B$ (Barrow fields) and $C-D$ (Walakpa field)

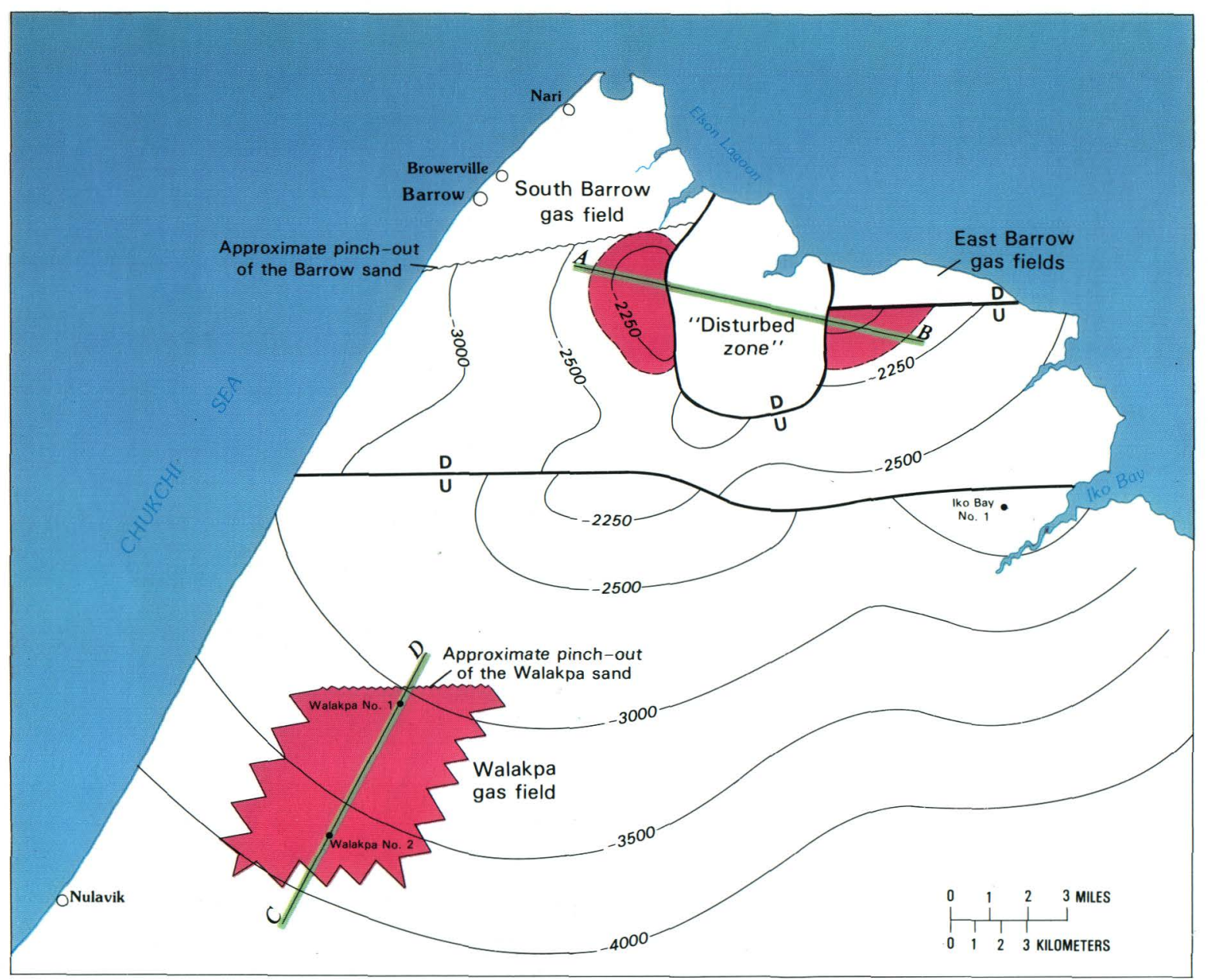

THE NATIONAL PETROLEUM RESERVE IN ALASKA 
The three known gas accumulations are all less than 3,000 feet deep. The South and East Barrow fields, though not connected, produce from the same stratigraphic horizon-the Barrow sand. The Walakpa field produces from the Walakpa sand slightly younger and a little above the Barrow sand in the stratigraphic section. Both sands have limited distribution, are of Mesozoic age, and have similar reservoir properties.

Possibly because it occupies the highest struc tural position in the area, the Barrow district appears to be gas prone. Oil in commercial quan tities has not been found, although some was recovered from thin sand of Cretaceous age in the Barrow No. 20 well.
$A$

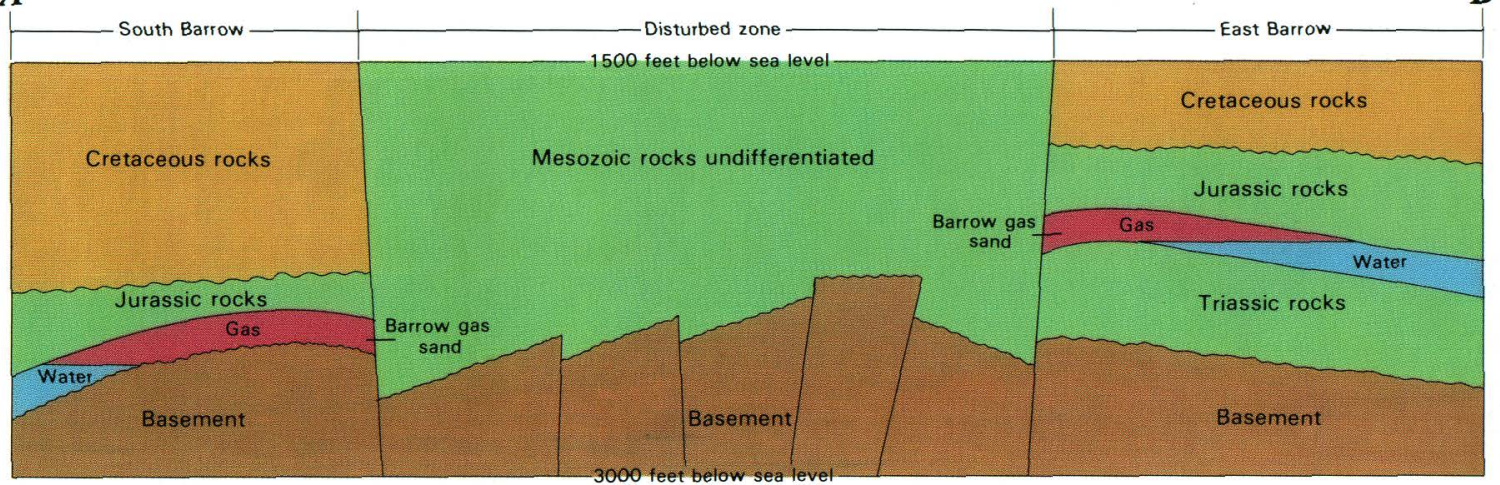

Schematic cross section through the South and East Barrou gas fields along line A-B. This cross section illustrates what petroleum geologists call a "trap." Oil and gas are lighter than water and thus will migrate upward until they are "trapped" in a place from which they cannot escape. The South and East Barrow fields are structural traps - the rocks slope away in all directions, and the hydrocarbons are trapped in the highest part of the arch, or structure. In contrast. the Walakpa field, shown in cross section below, is an example of a stratigraphic trap. Disappearance of the Walakpa sand (reservoir) updip traps the hydrocarbons when they have migrated as far up the reservoir as possible.

C

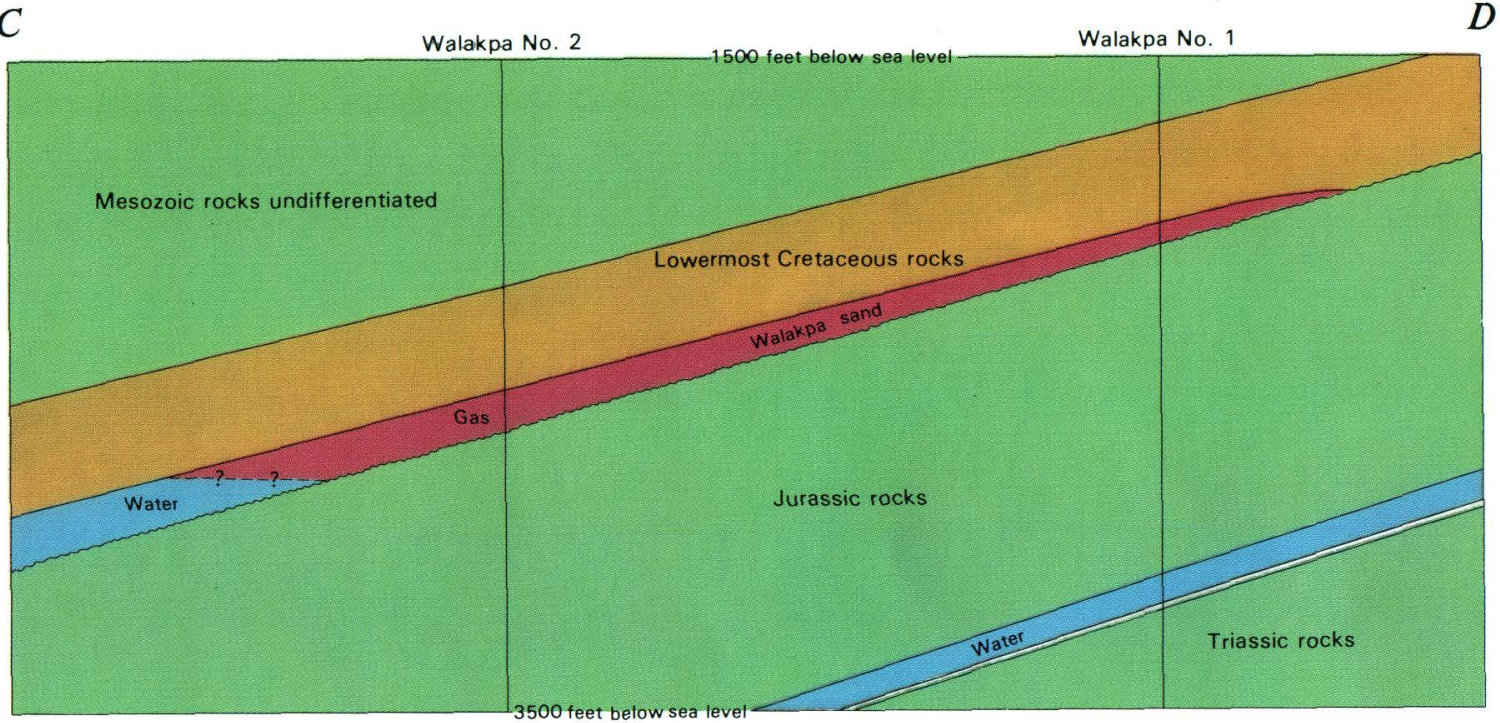

Schematic cross section through the Walakpa gas field along line $C-D$. The Barrow sand, reservoir rock of the Barrow gas fields, is present in the Walakpa area but does not form a trap and contain only water. The Walakpa gas field has not been developed and has produced no gas except for a small amount during testing of the two wells. 


\section{The USGS' accomplishments at Barrow}

When the USGS was assigned the responsibility of providing gas to the Barrow community, only the South Barrow field was equipped with the facilities necessary to produce gas and with the pipeline connections required to transport the gas to consumers. The East Barrow field consisted of one well but was without producing facilities or pipeline connections. There were no roads to the fields, and the environmental degradation resulting from 28 years of operating the South Barrow field without roads was deplorable. The ratio of remaining producible gas to gas consumption was below normal standards, and gas consumption was increasing rapidly.

The first priority was to find out whether the East Barrow field contained sufficient gas to justify construction of a pipeline and production facilities. Two wells were drilled during the first winter of operation (1977-78). Barrow No. 17 was drilled more than a mile west of the existing well (Barrow No. 14); it penetrated the gas-water contact and established the field-producing limit. Barrow No. 19 was drilled northeast near the crest of the structure, to determine the reservoir characteristics. The wells were extensively cored and tested to obtain the maximum data. Calculations based on this new information indicated that sufficient gas was present to justify construction of production facilities and pipelines, because operation of the new field would nearly double existing reserves.

Construction of the road between the Barrow gas fields. What appear to be large boulders along the shoulder are frozen blocks of gravel. The equipment is operating on an ice road alongside the gravel road. This ice road was built to speed construction; it disappeared with the spring thaw. To conserve gravel the road is one lane wide, with wider spots every quarter-mile to allow vehicles to pass; even so, about half a million cubic yards of gravel was required for the gas-field roads. Photograph by Robert Lantz.

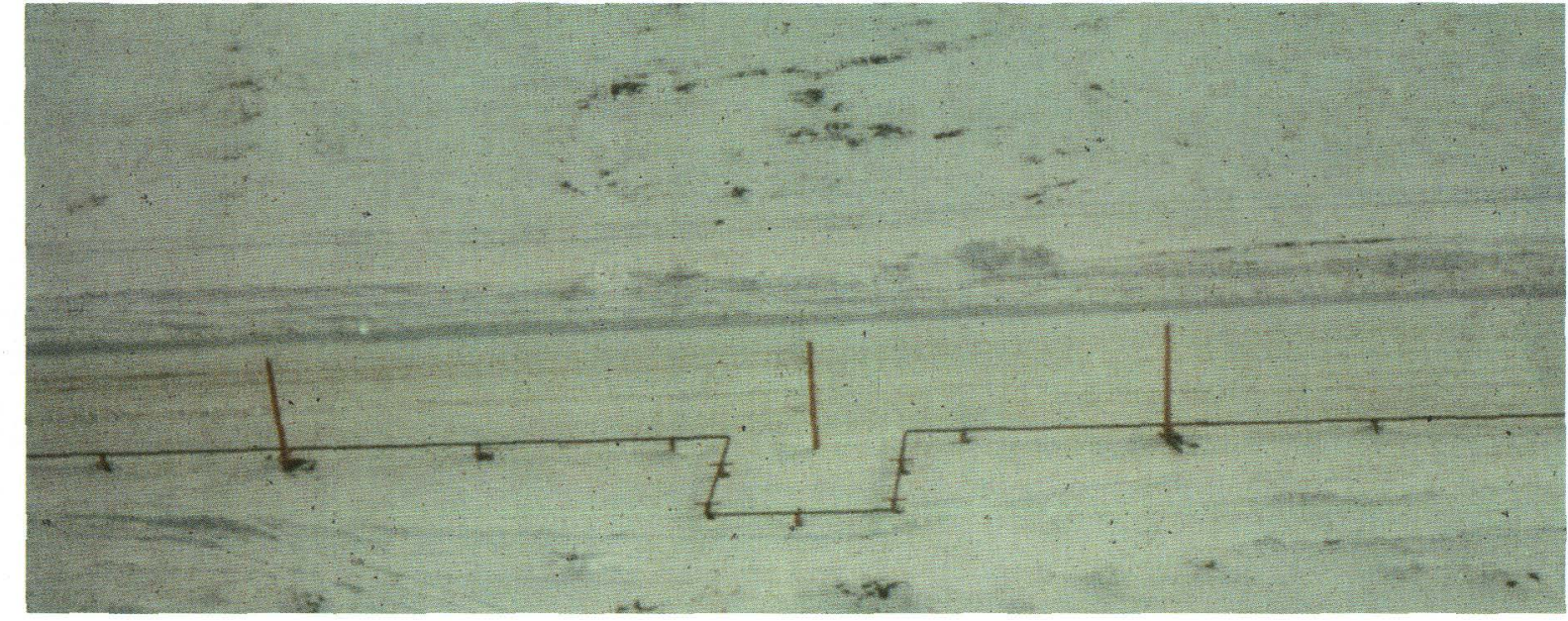

Part of the 6-inch-diameter pipeline from the East Barrow gas field. Expansion loop (center) allows the steel pipe to expand and contract without breaking. The pipe is anchored midway between the expansion loops, which are spaced at regular intervals to avoid any large accumulated movement. The pipeline is supported above ground on wood piling. The taller supports now carry electricity to the East Barrow field. Photograph by Robert Lantz.

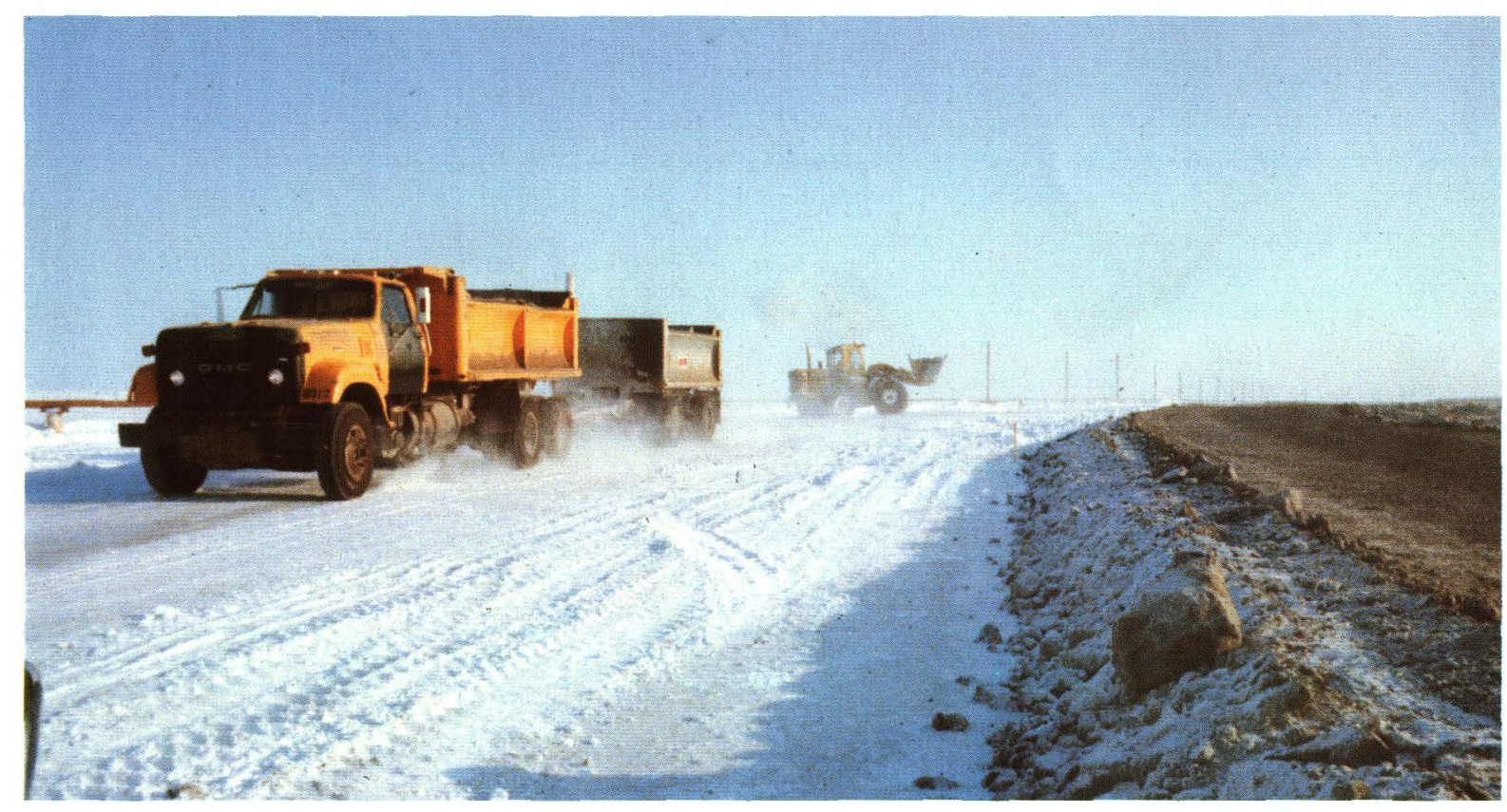

THE NATIONAL PETROLEUM RESERVE IN ALASKA 
With this positive information in hand, work began at once. Three additional wells were drilled, although one (Barrow No. 20) was damaged during cementing operations and could not be completed as a gas well. An all-weather gravel road was constructed to the gas fields to end the environmental damage associated with gas-field operations. A pipeline was built to carry the gas from the East field to the South field. The old South Barrow producing facility was inspected, and some needed safety features were added. A remote monitoring system was installed. Larger well houses and flowlines were installed at East Barrow than had been used at the South Barrow field, for added safety and reliability. Emergency electrical generating equipment was installed in the gas field as an additional safeguard against interruption of the flow of gas. The East Barrow gas field was brought into production in 1981.

While the gas fields were assigned to the USGS, the producible reserves of gas were increased several times over. A road network was built to minimize environmental damage. Automatic valving and electrical generating equipment, as well as a state-of-the-art producing facility at the East field, were installed. Installation of a system that permits remote monitoring of all key points in the entire producing system and all well houses resulted in a much safer operation and a more reliable supply of gas. The Walakpa gas field was discovered-a field that could contain sufficient gas to supply the energy needs of the Barrow community well into the 21 st century.

The current status of all important functions at each well and at each $M \boxminus R$ station is checked several times each minute by electronic devices (left) and displayed on a computer terminal located in the office (right). The system automatically sounds an alarm, accompanied by a flashing light that indicates what is wrong, as soon as it senses faltering well or production-system performance. The monitoring system normally operates over telephone lines, but it has a radio backup should the telephone lines fail. Automatic shutoff valves have been installed on the transmission lines, and on wells where possible, to make operating the gas fields much safer. Photograph by David Fears.

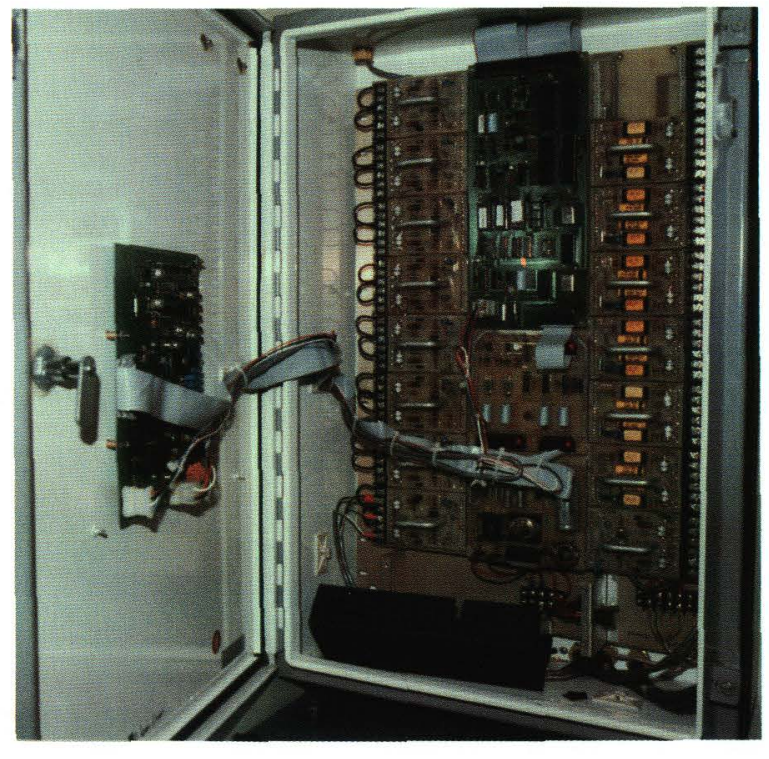

A remote monitoring system was recently installed to assure an uninterrupted flow of gas. 


\section{What is happening with the leasing of NPRA lands?}

Leasing of lands in the NPRA commenced shortly after the Congress authorized private oil and gas exploration and development of the Reserve in the Supplemental Appropriations Act (Public Law 96-514) ending fiscal year 1981. The provisions of that act have shaped the BLM's leasing policy. Five of these provisions are:

(1) activities in the NPRA will be environmentally sound;

(2) bidding is to be based on the bidding systems used for large offshore tracts;

(3) the size of a tract may not exceed 60,000 acres;

(4) primary leasing term will be 10 years and will be extended so long as paying quantities of oil and gas are produced, and

(5) half of the leasing receipts are to go back to the State of Alaska.

Some of these provisions were unusual in comparison with the regular leasing procedures set for other onland areas of the United States. Because of the vast size of the Reserve (the second lease sale of 3.5 million acres was the largest Federal offering in history), the BLM was required to use the same leasing technique that is used for large offshore

Generally, the leadup to an NPRA lease sale is a four-part process. First, there is a period of exploration and information gathering; then, private companies are asked to submit nominations and comments about interest areas. The BLM then selects the location and size of the tracts, and identi- tracts. For offshore lease sales, private companies submit sealed bids; for onland sales, the BIM determines a fixed price for each tract, and the names of private companies are drawn from a lottery. Also owing to the large tract size, the Congress deter mined that the environmental-impact statement completed in 1977 for the entire NPRA satisfied the Environmental Protection Agency's requirements for the first two sales of as much as 2 million acres In most cases, the private company is to provide the environmental-impact statement for each leased tract.

The NPRA is an ecologically sensitive area, and the subsistence of many Native people is intimately tied to its ecology. In addition to developing regulations protecting the NPRA, the BLM staff gathered new information by visiting North Slope villages Through public meetings and questionnaires, the BLM hoped to identify additional criteria of concern to the Native people. A list of possible leasing strategies, covering a broad range of environmental ideas, was presented for public comment. The BLM hoped that by working with the public, a management strategy could be devised that would "best mitigate impacts on the values of the reserve."

fies any special environmental regulations for each area. Finally, on a certain scheduled day, the actual lease sale is held.

Four lease sales have been offered to date: December 1981, May 1982, July 1983, and July 1984. A fifth sale is scheduled for July 1985 . 


\section{Summary of the USGS' accomplishments in the NPR-4/NPRA program}

NPR-4 was set aside in 1923 by Presidential order as a potential source of oil for the U.S. Navy. The petroleum potential of northern Alaska and the outline of the Reserve were based largely on early explorations by the U.S. Navy and the USGS, and on information collected by other explorers (primarily $\mathrm{E}$. de $\mathrm{K}$. Leffingwell) but published by the USGS.

Between 1923 and 1976, the USGS worked cooperatively with the U.S. Navy to further define the geologic framework, assess the petroleum and other mineral resources, and provide base maps of the Reserve. In 1976, the U.S. Congress transferred responsibility, renamed the Reserve, and redefined the role of the Federal Government. The USGS was assigned the responsibility of continuing the exploration program begun by the Navy, maintaining and operating the Barrow gas fields, and completing the cleanup and rehabilitation of the Reserve and adjoining areas. The Federal exploration program has now been terminated, and a leasing program has begun. Transfer of the Barrow gas fields to the North Slope Borough took place October 1, 1984. The last stage of the cleanup program was completed in summer 1984 .

Throughout the history of NPR-4/NPRA, the USGS has carefully documented and made available to the public, largely through its own publications, all the geotechnical information gained through Federal programs. In addition, it has integrated this information with private-exploration results outside the NPRA and periodically reassessed the petroleum potential and the geologic framework of the entire northern Alaska petroleum province and the adjacent Continental Shelf These are the only Arctic regions within the sovereign domain of the United States, and they are among the last frontier regions for mineral-resource exploration and development. Because of the Arctic climatic and geographic setting, the wilderness aspects, and the indigenous population, these studies present many problems that are unique. The mineral-resource and geotechnical-engineering information has been utilized by Federal agencies in the management of these public lands and by industry to explore and develop the resources.

A vast amount of geotechnical information on which to base further exploration has been collected and is available in publications and in contractor reports released by the USGS. A few examples are listed in the bibliography that follows to illustrate some results of the program and the kind of information that is available.

\section{Exploration program and hydrocarbon assessment}

- The USGS completed the systematic exploration program as mandated by the Naval Petroleum Reserves Production Act of 1976 (Public Law 94-258). A total of 28 test wells were drilled, 7 under U.S. Navy and 21 under USGS supervision; 6 test and development wells were drilled in the Barrow gas fields. Nearly 15,000 line-miles of seismic surveys were completed and interpreted, in addition to the more than 3,000 line-miles completed in the Pet-4 program from 1943 to 1953 , which were reinterpreted and integrated into the new surveys.

- Subsurface samples, cores, and cuttings were collected systematically in both the 1943-53 and 1974-82 programs. Because of the frontier nature of the region and the emphasis on a regional evaluation, a larger than usual number of samples were collected, curated, and made available for study in Anchorage, Alaska.

- These subsurface samples were studied by specialists in geochemistry, paleontology, petrology, and core analysis. The basic data and interpretations resulting from these studies are all available.

- An original program for an interactive computer-based data and graphics system was designed with the aid of contractors and is available to the public. This system includes files for base maps, daily drilling reports, digitized subsurface logs, seismic shotpoints, outcrop data, geochemical data and interpretation, and paleontologic information. 
- Models of the depositional paleoenvironment have been developed for sandstones of Jurassic and Cretaceous age that are the main prospective reservoirs in the NPRA.

- The first test well in the Foothills thrust belt of the NPRA, the Lisburne No. 1 test well, was drilled to a depth of 17,000 feet. It penetrated five distinct thrust plates, confirming the structural interpretations of the prospect, but no hydrocarbon deposit was discovered.

- Two deep exploratory wells (at the time of drilling, the deepest anywhere in Alaska) were drilled at Tunalik and Inigok. The Tunalik well reached a depth of 20,335 feet and penetrated strong blows of gas in a thick section of CretaceousJurassic rocks. The Inigok well, which was drilled to 20,102 feet to test a deep basement structure, pene trated an unusual and unexpected flow of sulfur and hydrogen sulfide.

- About 15 miles southwest of the Barrow gas fields and downslope from the Barrow structural high, the Walakpa test well penetrated a new gas deposit. A second well extended this discovery, but no additional wells were drilled. Thus, the size of this field has yet to be determined, although it is probably larger than the Barrow fields by a factor of 10 or more. It could provide gas to the local com munities well into the 21 st century.

- Inasmuch as the exploration program was aimed at an assessment of the oil and gas potential of the entire NPRA, a new approach was developed. A total of 17 petroleum plays-areas of geologically similar prospects-were delimited, and a program to test each was planned and largely completed.

- For all of these plays, the amount of undiscovered crude oil in place is estimated at 0.82 billion barrels at a 95-percent probability and 15.4 billion barrels at a 5-percent probability, for an average of 5.97 billion barrels.
- The total amount of undiscovered natural gas in place is estimated at 2.4 trillion cubic feet (TCF) at a 95-percent probability and 27.2 TCF at a 5-percent probability, for an average of $11.3 \mathrm{TCF}$.

- The exploration program has extended and refined our knowledge of the geologic framework of Arctic Alaska and the adjoining Continental Shelf The geologic structural framework is described as consisting of three distinct structural provincesthe Arctic platform, the Foothills fold belt, and the Brooks Range thrust belt. The stratigraphic section is described as consisting of three sequences-the Franklinian rocks of pre-Mississippian age, the Ellesmerian rocks of Mississippian to early Early Cretaceous age, and the Brookian rocks of late Early Cretaceous to Holocene age.

- Interpretations based on plate tectonics suggest that the Canada Basin of the Arctic Ocean formed by rotational rifting of the Arctic platform away from the Canadian Arctic Islands during Jurassic to Early Cretaceous time, and that the southwestward drift of this platform created the Foothills fold belt and the Brooks Range thrust belt by underthrusting.

\section{Cleanup, rehabilitation, and environmental considerations}

- Cleanup of debris left by earlier workers in the NPRA and adjoining areas was begun by the U.S. Navy in 1971 mainly in and near the Barrow and Umiat base facilities. The USGS extended this program, reaching out to the remote corners of the NPRA, and completed the cleanup in 1984. Although no precise records exist of the amount of debris collected, it totals tens of thousands of tons of noncombustible materials and hundreds of thousands of 55-gallon drums-the ubiquitous containers for fuel throughout the remote areas of Alaska.

- For efficiency of operation, cleanup and rehabilitation of the earlier sites were combined with work on the sites of the $1974-82$ exploration program. This program involved about 540 of the $23,680,000$ acres of the Reserve, and seismic sur veys traversed nearly 15,000 line-miles. Except for permanent runways, these areas will return to a near-natural state within a few years.

- To maintain minimum environmental impact the USGS agreed with the land managers-the BLM-on a system for advance planning, stipulations, and monitoring that set a standard for such cooperation on Federal lands in northern Alaska.

- Environmental stipulations mutually agreed upon by the BLM and the USGS have been carefully monitored by both agencies and by their contractor personnel, and impacts were maintained at an acceptable level.

- A thin-pad design for one-season winter drilling proved to be environmentally preferable and more cost effective than a thick-pad design. Thin pads are more quickly assimilated into the natural surroundings than are thick pads.

- Ice roads, properly constructed, proved to be practical and cost effective, and had little or no visible effect on the tundra.

- Ice airstrips on lakes or constructed by flooding on shallow ponds or marshes proved to be practical and cost effective, and had no adverse environmental impacts.

- Preclearance for environmental, cultural, and archeologic reasons was required and was carried out for all active sites. These surveys and studies contributed much valuable information on archeologic sites. 


\section{Operation and maintenance of the Barrow gas fields}

- The USGS operated and maintained the Barrow gas fields for the benefit of the Barrow communities and Federal Government installations until October 1, 1984.

- The East Barrow gas field was discovered by the U.S. Navy in 1974, but it remained for the USGS to prove the development potential, complete the facilities, and bring the field into production. Both reserves and delivery are expected to meet anticipated demand at least through 1989.

- The USGS discovery of a new gas field at Walakpa provides the possibility for extended use of gas as the main energy source for the Barrow communities beyond the year 2000 .

- The USGS completed a thorough testing program - the first in the history of the fields-to establish reserve limits, individual well capabilities and characteristics, and maximum safe-delivery rates.

- A modernization program was begun to help reduce costs and to increase safety and efficiency. All-season gravel roads were constructed to vital facilities, not only to increase effective operation and safety, but also to reduce environmental impacts caused by repeated vehicular traffic over the surrounding tundra.

- Public Law 98-366, the Barrow Gas Field Transfer Act of 1984, relieved the Secretary of the Interior (and, thus, the USGS) of the responsibility for supplying natural gas to the Barrow community, effective October 1, 1984. The entire gas system is now operated by the North Slope Borough. The USGS is to furnish technical assistance to the borough until October 1, 1989.

\section{Termination of the NPRA program}

- In 1982, the NPRA program of the USGS was terminated. The BLM now has the overall responsibility for management and protection of the land within the Reserve. In accordance with the MOU, the USGS has completed its responsibilities, and the area has been returned to the BLM. The project has exemplified how a good working relationship between Government and industry, as well as cooperation of two larger government agencies-the BLM and the USGS-can serve to safeguard the best interests of all concerned. 
References cited

Bird, K. J., 1981, Petroleum exploration of the North Slope in Alaska, U.S.A.: U.S. Geological Survey Open-File Report 81-227, $43 \mathrm{p}$.

Bowsher, A. L., and Dutro, J. T., Jr., 1957, The Paleozoic section in the Shainin Lake area, central Brooks Range, Alaska: U.S Geological Survey Professional Paper 303-A, p. 1-39.

Brooks, A. H., 1909, Petroleum in the mining industry in 1908 U.S. Geological Survey Bulletin 379-A, p. 21-62.

Chapman, R. M., and Sable, E. G., 1960, Geology of the Utukok-Corwin region, northwestern Alaska: U.S. Geological Survey Professional Paper 303-C, p. 47-167.

Collins, F R., 1958, Test wells, Meade and Kaolak areas, Alaska, with a section on Micropaleontology of Meade test well 1 and Kaolak test well 1, northern Alaska, by H. R. Bergquist U.S. Geological Survey Professional Paper 305-F, p. $341-376$

_ 1958, Test wells, Topagoruk area, Alaska, with a section on Micropaleontologic study of the Topagoruk test wells, northern Alaska, by H. R. Bergquist: U.S. Geological Survey Professional Paper 305-D, p. 265- 316

1958, Test wells, Umiat area, Alaska, with a section on Micropaleontologic study of the Umiat field, norther Alaska, by $\mathrm{H}$. R. Bergquist, and sections on Temperature measurement studies, by M. C. Brewer, and Core analyses, Umiat test well 9, by G. L. Gates: U.S. Geological Survey Professional Paper 305-B, p. 71-206.

- 1959. Test wells, Square Lake and Wolf Creek areas, Alaska, with a section on Micropaleontology of Square Lake test well No. 1 and the Wolf Creek test wells, northern Alaska, by H. R. Bergquist: U.S. Geological Survey Professional Paper 305-H, p. 423-484

1961, Core tests and test wells, Barrow area Alaska, wit a section on Temperature measurement studies, by M. C Brewer: U.S. Geological Survey Professional Paper 305-K p. $569-644$.

Drilling Department, 1983, Design and construction of the walakpa Test Well No. 2: Anchorage, Alaska, Husky Oil NPR Operations, Inc., $52 \mathrm{p}$

Ferrians, O. J., Jr., Kachadoorian, Reuben, and Greene, G. W, 1969, Permafrost and related engineering problems in Alaska: U.S. Geological Survey Professional Paper, 678 p.

Gryc, George, Miller, D. J., and Payne, T. G., 1951, Alaska, in Ball M. W., ed., Possible future petroleum provinces of North America: American Association of Petroleum Geologists Bulletin, v. 35, no. 2, p. 151-168.

Haugen, R. K, and Brown, Jerry, 1971, Nature and man-induced disturbances of permafrost terrain, in Environmental geo morphology: Binghamton, State University of New York, $p$ 139-149.
Hewitt, S. L., 1983, Design and construction of the Lisburne Tes Well No. 1: Anchorage, Alaska, Husky Oil NPR Operations, Inc., $26 \mathrm{p}$

Keller, A. S., Morris, R. H., and Detterman, R. L., 1961, Geology of the Shaviovik and Sagavanirktok Rivers region, Alaska: U.S Geological Survey Professional Paper 303-D, p. 169-222

Lachenbruch, A. H., 1970, Some estimates of the thermal effects of a heated pipeline in permafrost: U.S. Geological Survey Circular 632, $23 \mathrm{p}$.

Leffingwell, E. de K, 1919, The Canning River region, northern Alaska: U.S. Geological Survey Professional Paper 109, 251 p.

Mertie, J. B., Jr., 1979, Monazite in the granitic rocks of the Southeastern Atlantic States--an example of the use of heavy minerals in geologic exploration: U.S. Geological Survey Professional Paper 1094, $79 \mathrm{p}$

Miller, D. J., Payne, T. G., and Gryc, George, 1959, Geology of possible petroleum provinces in Alaska with an Annotated bibliography, by E. H. Cobb: U.S. Geological Survey Bulletin 1094, $131 \mathrm{p}$

Mitchell, D. W., 1983, On-tundra ice airstrips in NPRA Anchorage, Alaska, Husky Oil NPR Operations, Inc., 22 p

1983, Design of NPRA winter drilling pads, 1976-1978 Anchorage, Alaska, Husky Oil NPR Operations, Inc., $9 \mathrm{p}$ -1983, Design of NPRA winter drilling pads, 1979-1981 Anchorage, Alaska, Husky Oil NPR Operations, Inc., 9 p.

National Petroleum Reserve in Alaska Task Force, 1978, Ecolog cal profile: Anchorage, U.S. Department of the Interior (National Petroleum Reserve in Alaska Task Force Stud Report 4), $118 \mathrm{p}$

Patton, W. W., Jr., 1957, A new upper Paleozoic formation, centra Brooks Range, Alaska: U.S. Geological Survey Professional Paper 303-B, p. 41-45.

- 1964, Petroleum and natural gas in Northern and Interior Alaska, in Mineral and water resources of Alaska: Wash ington, U.S. Geological Survey report to U.S. Senate Committee on Interior and Insular Affairs, p. 62-77.

Patton, W. W., Jr., and Matzko, J. J., 1959, Phosphate deposits in northern Alaska: U.S. Geological Survey Professional Pape 302-A, p. 1-17.

Reed, J. C., 1958, Exploration of Naval Petroleum Reserve No. and adjacent areas, northern Alaska, 1944-53; part 1, His tory of the exploration: U.S. Geological Survey Professional Paper 301, $192 \mathrm{p}$

Rickwood, F. K., 1970, The Prudhoe Bay field, in Proceedings of the Geologic Seminar on the North Slope of Alaska: Los Angeles, American Association of Petroleum Geologists, p. L1-L.1 1

Robinson, F. M., 1956, Core tests and test wells, Oumalik area Alaska, with a section on Paleontology of test wells and core tests in the Oumalik area, Alaska by H. R. Bergquist: U.S. Geological Survey Professional Paper 305- A, p. 1-70.
1958, Test well; Grandstand area, Alaska, with a section on Micropaleontologic study of Grandstand test well 1 northern Alaska, by H. R. Bergquist: U.S. Geological Survey Professional Paper 305-E, p. 317- 339.

1958, Test wells, Gubik area, Alaska, with a section on Micropaleontologic study of the Gubik test wells, northern Alaska, by H. R. Bergquist: U.S. Geological Survey Professional Paper 305-C, p. 207- 264.

- 1959, Test wells, Simpson area, Alaska, with a section on Core analyses, by S. T. Yuster: U.S. Geological Survey Professional Paper 305-J, p. 523- 568

_ 1959, Test wells, Titaluk and Knifeblade areas, Alaska, with a section on Micropalcontologic study of test wells in the Titaluk and Knifeblade areas, northern Alaska, by $\mathrm{H}$. R. Bergquist: U.S. Geological Survey Professional Paper 305-G, p. 377-422.

Robinson, F. M., and Collins, F. R., 1959, Core test, Sentinel Hill area and test well, Fish Creek area, Alaska: U.S. Geological Survey Professional Paper 305-I, p. 485-521.

Schindler, J. F, 1983, History of the second exploration, 1975-1982: Anchorage, Alaska, Husky Oil NPR Operations, Inc

Schrader, F. C., 1904, A reconnaissance in northern Alaska across the Rocky Mountains, along Koyukuk, John, Anaktuvuk, and Colville rivers and the Arctic coast to Cape Lisburne in 1901, with notes by W. J. Peters: U.S. Geological Survey Professional Paper 20, 139

Smith, P. S., 1941, Possible future oil provinces in Alaska: Amer ican Association of Petroleum Geologists Bulletin, v. 25 no. 8 , p. $1440-1446$

Smith, P. S., and Mertie, J. B., Jr., 1930, Geology and mineral resources of northwestern Alaska: U.S. Geological Survey Bulletin 815, $351 \mathrm{p}$.

Spetzman, L. A., 1959, Vegetation of the Arctic Slope of Alaska: U.S. Geological Survey Professional Paper 302-B, p. 19-58.

Stoney, G. M., 1900, Naval explorations in Alaska: Annapolis, Md U.S. Naval Institute, 105 p. [reprinted by University Microfilm, Inc., Ann Arbor, Michigan, 1960.]

Tailleur, I. L., 1983, Stratigraphy, structure, and palinspastic synthesis of the western Brooks Range, northwestern Alaska: U.S. Geological Survey Open-File Report 83-779, 57 p

U.S. Bureau of Land Management and National Petroleum Reserve in Alaska, 1977, Memorandum of understanding Federal Register, v. 42, no. 16, p. 4542- 4546

U.S. Department of the Interior, Office of Minerals Policy and Research Analysis, 1979, Final report of the 105(b) economic and policy analysis: Washington, U.S. Government Printing Office, $145 \mathrm{p}$

Williams, J. R., Yeend, W. E., Carter, L. D., and Hamilton, T. D. 1977, Preliminary surficial deposits map of National Petroleum Reserve, Alaska: U.S. Geological Survey Open-File Report 77-868, scale 1:500,000, 2 sheets. 


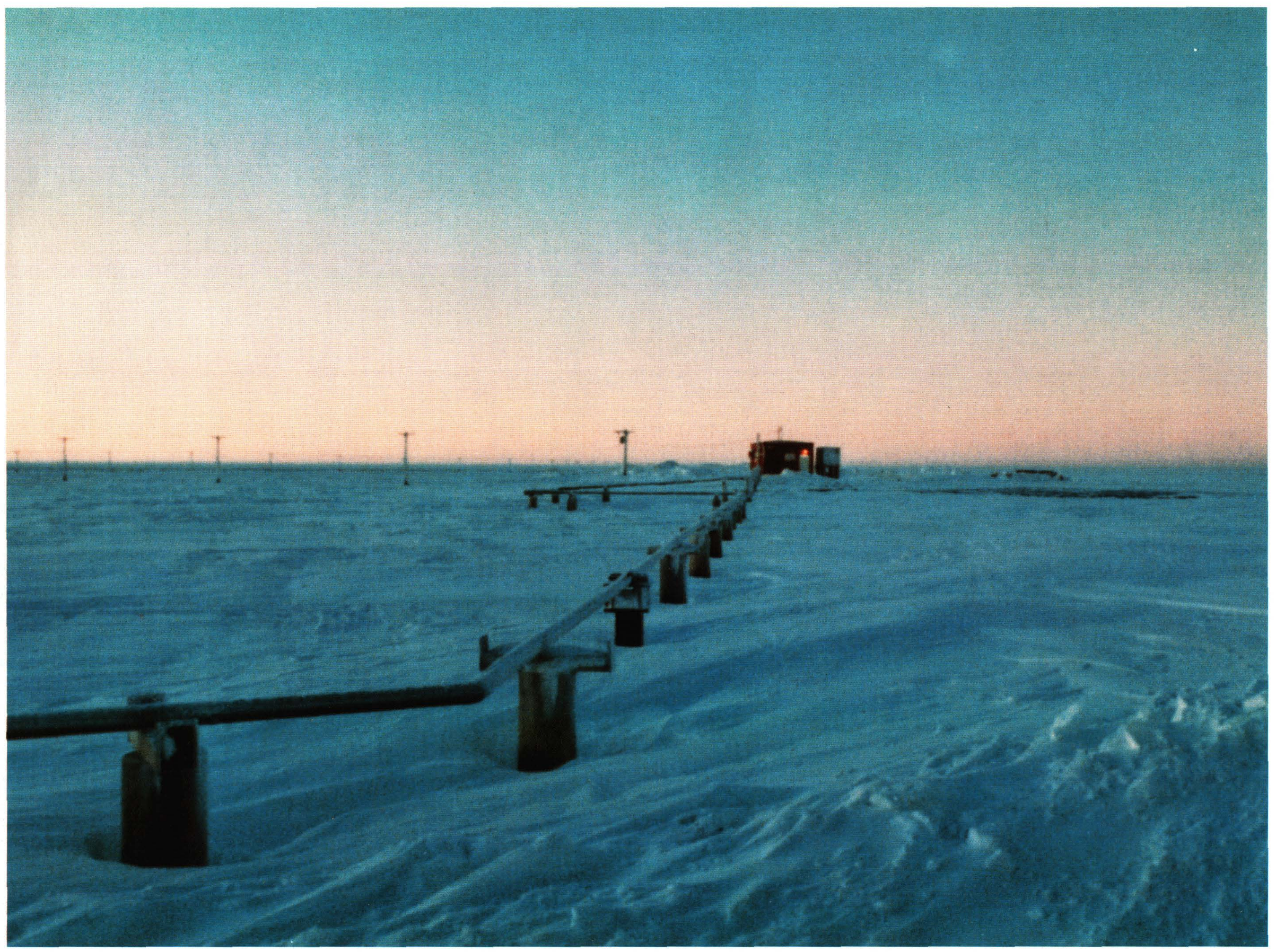

Dusk over East Barrow. Photograph by Robert Lantz. 
This report is the third in a series of Earth-Science Special Reports being prepared by the U.S. Geological Survey to provide the public with timely and useful information on earth-science considerations relative to critical land, mineral, and water-resource issues that currently face the Nation.

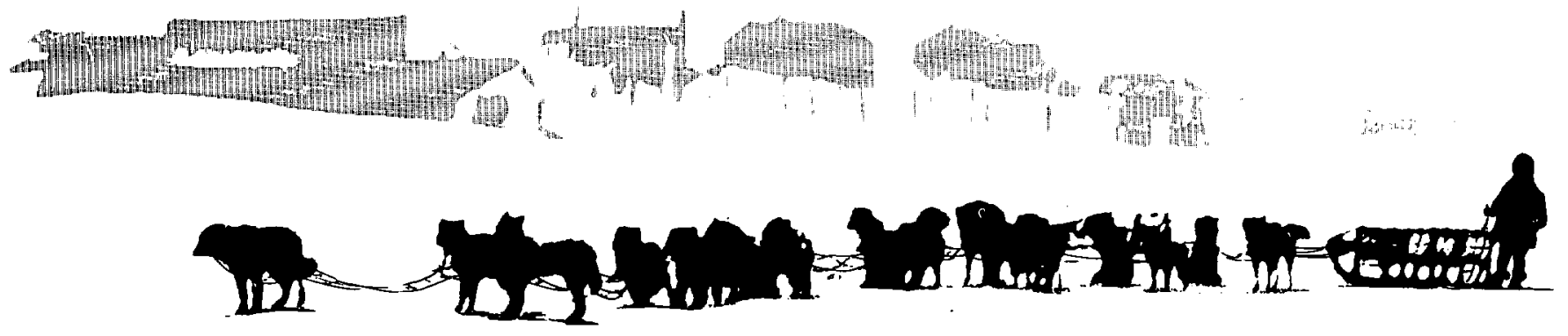


